QL

555

S9W563

1903

ENT

THE

\title{
butterfies of Switzerland
}

AND THE

Alps of Central Europe.

11)

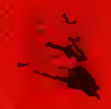

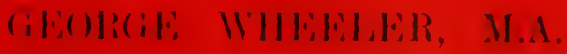

Price 5s. nes, Interleaved os.

I, HIIUA .

R.IJIOTT STOCK,

02. PAFHe gTER lien, D. C.

Aripuie, ryo, s 



$$
101
$$





\section{GL}

555

Sqlu $56=$

1902 THE

\section{Butterflies of Switzerland}

AND THE

Alps of Central Europe.

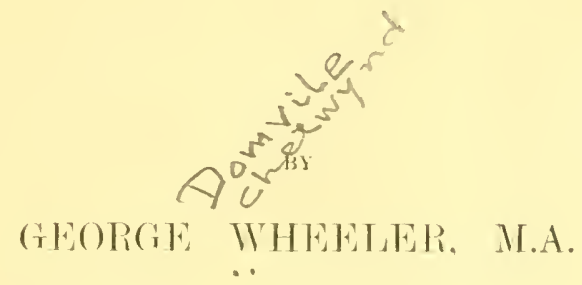

Price 5s. net, Interleaved os.

ELLIOTT STOCK,

62, Patersoster liow, E.C. 
JAN 141949

NATIONAL M USE 
. 156

Ln... 



\section{LNTROTUCTION.}

The difticulty I expreriencerl, when beginning to collect butterflies in Switzerland, in finding ont what to look for, and when and where to look, and the discovery that many others were in the same situation. first opened my eyes to the neressity for a look with some such scope as the present. No work tealing with the Siviss buttertlies its a whole had ilppeared since Frey's "Lepidopteren der Schweiz" in 18s0, thongh Litng's " Buttertlies of Enrope" was published in 1s84, and 188.5 saw the production of the "Enropean lintlerflies" of liane, who hats become the "guide, philosopher and friend" of a large and ever-increasing number of Jiritish lepidopterists in the Alps and elsewhere. Moreover, not only had new species lreen discovered since that time, but one of the looks was in Gepman, another decidedly expensive and not very portahle, and the third, I was informed on trying to obtain a copy, sold out; and in neither of them was the subject of valration, so intensely interesting even to the "mere collector," more than lightly tonched on. It was not, howerer, until much later that l even contemplaied the possibility of trying to sitpply the deficiency, an irlea which was first snggesterl to me after the publication of some of my paper's in the lintommlougist's limord, when I found, to my own great surprise, that my advice wits asked, and ruy opinion consulted, by entire strangers, even including, during the last two years, some of the best known lepidopterists of Switzerland. 'This circumstance, together with the fact that no one else seemed willing to throw himself into the breach, must be my excrise for molertaking the task; and, if it be a case of "where ingels fear to tread," I can only plead that at least I have not "mish in." Often the inclusion, or even the sup. pression, of a single line has entailed the close examination of many specimens, and a most mexpected amount of correspondence.

The original idlea was to include swiss butterflies only, but Switzerland is so entirely a political rather than a geographical expression, that it seemed necessary either to enlarge or diminish the scope of the worls, and, after much consideration, the whole of the Alps of Central Europe have been included; $i$.r., the Alpes-Maritimes, the Hantes and Fiasses Alpes, and Savoie in France; the Alps of N. Italy; the Tyrol; the Styrian, Carinthian and Julian Alps, and snch small portions of the S. of Uper and Lower Austria as are alpine. At the same time the original itlea has not been lost sight of ; the whole of Switzerland is included whether alpine or not (which has involved the inclusion of the French Inra), anc those species and rarieties which have never bern taken in Switzerland are marked with an asterisk (*), for the consenience of those collectors (no insignificant number) who confine their attentions exclusively to the butterflies of that country. It will also, no doubt, be at once perceiver that the localities given ontside switzerland are both fewer mol often less precise than those within it, especially with regard to the more eastern portion of the recrion; and I must at once admit that I feel myself far less well equipped for dealing with the latter portion of the subject, both from 
being personally unacquainted with the combry, and from the lact that it has been very little worked except in the neighbourhood of a few centres.

'The whole subject has been as much condensed as possible, and, to save space, abbreviations (lists of which are given) are very freely nsed. With the same view, descriptions are reduced to a minimum; the prevailing colours of each tribe or genus are given, and often a distinguishing character of the latter; then, under each species, the synonyms, size, foolplant of the larva when linown, and the superficial difference between of and $q$ are noted, and one or more characteristics-as few as possible-given, by which each may be distingnished from its neighbours. This has been by far the inost exacting portion of the work; in every difficult case many specimens have been examined, and, in no instance, have the distinctions been drawn by refelence to books or plates alone, withont examination of the actrial insects themselves. It must be furthel understood that the characteristics given are often not those which scientifically differentiate one gemus, or even one species, from another (these being often more prominent in some earlier stage), but those which are easiest of recognition, and conseruently the most superficial. In the same way, secondary sexual distinctions have always been chosen by preference, and the androconial pockets are generally referred to by their appearance, $\iota . \%$. , " a thickening of the nerrures," "a black line," "ce., rather than by their actual structure or function. 'The stage at which hylernation takes place is given either molor the tribe, genus, or species. Localities are next mentioner, with dates and authorities, and I have by preference given the most modern instances that I can find, and have as far as possible talien, when there was any choice, those which have not been previously published, or which were scattered theough the pages of nagazines; the year has been adrled whenever possible, as times of emergence vary greatly with the season; the year 1899 , for instance, was abnormally forward; 1895 , and in the mountains 1902 , musually late. Lastly, special attention has leeen paid to ratration, and under the head of "Directions of Variation "a good deal of information is often implied concerning the type, which has enabled we to dispense with a considerable anount of direct description; when no localities are added after the varions forms mentioned it is to be understood that they occur with the type. Variation in size is only mentioned specially when it is prononnced, as all collectors must be aware that all species liffer somewhat in this respect; the size given in willimeters after the name of cach species is an arepage; this small bnt important item of information has involvod a great deal of actual neasmenent, the sizes given in Faro's "Lépidopteres dı Valais," which I had intended using as a basis, being generally, though by no means always, the largest to which each species attains, moless in abnormal cases.

With regard to Classitication and Nomenclature I hold strong riews, which would take far too much space to state bere, though I feile that certain inklings of them have forced their way out occasionally in notes; but there are two things which to me are anathema, to which I must shortly refer. The first of these is the breaking up of large genel'a into "genera of convenience." I feel most strongly that the division into genera ought, strictly speating, to correspond 


with a physological lact, and always with the some physiological falct, ris, the possibility of genuine hybridisation. 'This is, of course, merely an icleal which can only be reached by an immense amount of actual sxperiment, and for which negative evidenec requires to be: cummlative before it can bo regarded as having much force; but to search for characters ly which a genus can be split up, simply because it is large and "unwieldy" (why unwieldy? who wants to " wield" it?), or to divide genera by characteristics of varying importance, is to cut at the root of all possible development of classification on scientific lines. The second is the doctrine that the firstdescribur form of an insect (or of anything else) must be regarded as the type. It would perhaps be most scientitic to regard the nost ancestral form as the type if this were possil,le, but, as in most cases, it would be impracticable to determine which is the most ancestral form, the only possible alternative is to regarl as typical the most grenerally distributed form (surely in most cases a matter easy enough to determine), and others as varying from it. I cannot belp feeling that classification and nomenclature, even at the loss of some degree of fixity. ought to be marle subservient to scientific fact, rather than that such fact should be obscurer by a too pedantic adherence to the letter of the law of priority. With regard to the application of these principles to particular cases I am most humbly open to correction, from the principles themselres I see no reason to deviate.

While on the one hand, as Mr. 'Tutt and others have pointed out, no linear arrangenent of classification can be really satisfactory, it is obrious, on the other band, that both in books and collections no other is possible, and the problem is to choose the least objectionable, i.r., that which least glaringly contradicts scientific facts so far as they are established. It is, of course, highly improbable that any arrangement chosen would quite commend itself to anyone elso, unless to someone who had published one of his own which was strictly adhered to ; so, as I have mot strictly alhered to any, everyone is likely to find something to complain of, and, in fact, I have finally adopted the present one, not because 1 conld not find complaints against it myself, but because "in the present state of onr ignorance" I could find more against any other. I consulted Mr. 'I'utt on this matter', and have in most cases followed his suggestions, but the position which I have assigned to Nemeobius Lucina, and Libythea C'eltis will not, I fear, meet with his approval. The practice of hegrinning with the more generalised forms, though the more logical, has still probably many enemies.

With regard to the actual nomenclature employed, that of the IIesperiides is the most uncertain; I feel convincel that some at least of the generic names will prove to be incorrect, but pending further investigation, I bave applied them in accorlance with the use of others nore competent to juige than myself. If it be necessary to ignore Billberer's generic names in this case, it would appeal that laptidia should also give way to lontesin, IIb.; I have, however, retained c'allophrys, for which there seems to be no alternative. One ol two gencric divisions,

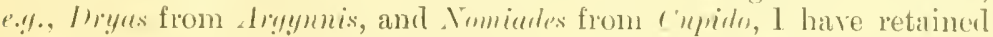
unwillingly, and I hope temporarily, but the genus Melampias (as woll as some others not generally adopted), I have felt it necessary to suppress. Onr knowledge of the carlier stages of the (inclusire) genus Fivela, is far too slight and fragmentary to serve as a basis for subdivision, the 
imames resemble one another so closely that no superticial difference wil] helpus, Professor Grote, whileaccepting the division, does not defend it by difference of nemation, and Dr. Chapman's organic researches would suggest a different subdivision if one were necessary. With regard to specific names there is little to be said. I have, in accordance with uny strongly expressed riews on "types," restored Aleris in place of lcarus, regarding the latter as a variety ( $r$. note in loro), but have retained the use of Aryms to replace. Foni, though I am by no nueans sure of the necessity, and yuite confident of the unwisdom, of so doing. Is it not much more probable that Limiens regarded both as one species, than that he was macquainted with the insect to which we bave all, until lately, applind his name Arous? and in the former case is there any necessity for a change of name? With regard to rarietal names I have only one renark to offer. It would be such a fruitful source of confusion if the silue name might be applied to one species, and to a rariety of another in the same genus (or even the same tribe), that the practice should never be tolerated, and such names as Frlusa var. 'hrysotheme, and Eifintem var, Mrlampus should be considered inadmissible. Only four changes of any importance from the established orter of things, will, I think, be found, $r i$ : the treatmont of $\mathrm{m}$.

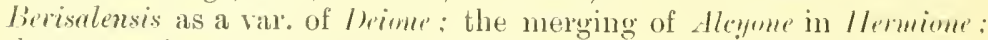

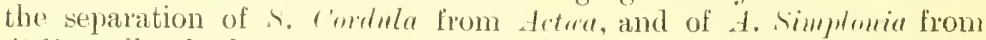
lirlia: all, whetler wenerally accepted or not, are the result of careful stmily and much discussion and correspondence. The last chance has alloady been made by 1)r. Spuler, and is, I think, justified in low: and the second, which is a reversion to the arrangement of Esper and Frey, hats the smport, anong many others, of such lepirlopterists as Professor Blachier and ('luanome Finre, notwithstanding the opinion beld by the latter when he pmblished his "Lepiloptires du Valais." As

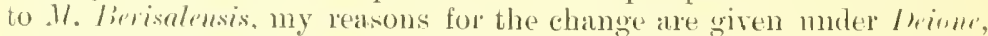
and thongh I find nyself in antagonism with so eminent a lepulopterist as 1)r. Chapman, I feel compelled to athere to my view. The

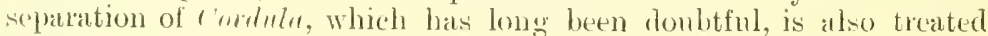
in lores.

On two minor points, literary rather than scientific, 1 tind myself at bariance with many writers with whom I should greatly prefer to find mysell in accord, but, in neither case, is there any moiformity of practice. In the first place it scems to me absure to alluere to the original spelling of a name when it is manifestly and admittedly in. correct, and in such cases l have never hesitated to alter it. IIhy retain sinch erors ats Coririon and Hegera? Secondly, I have speit all specitic names with eapitals; even at the cost of some con-

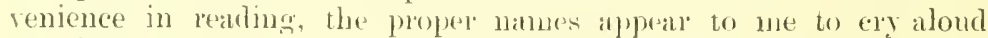
for them, and naturally I should have employed them for these only, but, as in all othes languages than onl own, capitals are considered incorrect for adjertires of place (r.\%., simplomia), a difficulty at once arises which seems most easily solved by capitalising all. I camnot, howerer. feel that this does away with all (or even with any) objection that might be felt to a disanreement between adjectives and their substantives, and that agrecment I have, therefore, maintained: but as both the words "varietas" and "aberratio" are fortunately. leminine, I have msed the feminine form in all cases lor varieties and aberrations. An apparent exception is coryilon ab. Calydonius, Lowc, 


but in this case the reference is to the resemblance of the colonr to that of yeleder, and I have regated the name rather ats a substantive than an aljective: one or two other similar instances ocenr.

Although the work makes no pretence at being exhanstive, no one can be more fnlly aware of its deficiencies than myself, but, whatever measure of success in its limited sphere it may have attained, is primarily due to the great kindness and nugrudging help afforded to me by many lepidopterists, both Finglish and Continental. It wonld be impossible to thank by name all who have given ne assistance, but there are some whom it wonld be inexcusalole to leave unmentioned. First and foremost my thanks are due to $\mathrm{M}_{\mathrm{r}}$. 'Tutt for help and en. conragement of all kinds; himself one of the busiest of men, he seems somehow to be always accessible, and, but for him, it may be safely asserted that this work would never have seen the light; much the same may be said of Mr. Page who has transacted all the business connected with its production. To the Rev. ('. J. Buckimaster, who has searched endless back mmmbers of magazines, which at the time of writing were out of my own reach; to Mr. Fisom, who has furnisher me with a great amount of hitherto unpublished material, and whose large collection of Swiss buttertlies, taken almost to an insect by himself, has been at all times at my disposal ; to P'rofessor Blachier and Chanoine Favre, who bave helped me with dates. localities, the nse of their collections, and wuch valuable correspondence; to Col. Agassiz. and M. W'nllschlegel, whose large collections and experience have been placed at nuy service; to Mr. F. (C. Lemamn, who nobly entrusted to me his interleaved copy of " Kane," that 1 might a vail myself of his MS. notes; to Mr. ( $\mathrm{i}$. (). Sloper, who gave me the unrestricted use of his note-looks, amd helped me in many other ways; to Miss lountaine, Mr. H. Rowland-Jirown, Mr. A. H. Jones, Mr. Powell. and others who have sent me most valuable lists of captures; to the liev. F. F. Lowe, Mdlle. Marie Riihl, and many more who have helped me in the matter. of aberrations, varieties, and a host of details- to each and all of thrse my most grateful thanks are hereby offered; and 1 must heg all who may find this little work nseful, to remember that it is to them that the credit of such nsefulness is mainly due. As a testimony to the great kindness of entomologists in general I should like to add, that

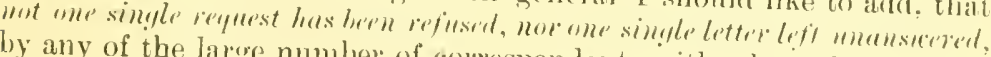
by any of the large number of correspondents with whom I have hail
canse to commonicate. 


\section{ABBREVIATIONS USED.}

Ab., aberration; abundant. c., common.

dist. char., distingnishing characteristic.

E., east, eastem.

esp., especially.

exc., except.

Fum., family.

id. plt., food plant. gen., general, generally. grd., ground.

hyl., hybernates, hybernated.

im., imago.

l., larva.

loc., locality.

mm., millimetres.

untn., mountain.
N., north, northern.

ov., ovum.

p., pupa.

S., soutl, southem.

sp., species.

v., very; ride.

var., variety; variation.

W., west, western.

wh., which.

Parts of the wing, de.

Ang., angle.

cl., central.

dise, discoidal.

inn. mary., inner margin. margl., marginal. out. snarg., outer masgin. un. s., under-side. up. s., upper-side.

\section{Colodrs, \&c.}

Pl., bine.

blk., black.

brn., brown.

lirt., bright.

col., colour ; colonrerl. dk., dark.

gr., grey.

grel. col., gronnd colour.

grn., green.

lt.. light. w., wing.

t.w. tore-wing.

h.w., hind-wing.

Month in small Roman fignres; i., January, de.; b., heginning, 1st to 10 th ; m., millle, 1 ith to 20 th; e., end, 21 st to end.

\section{NAMES OF AUTHORITIES.}

\begin{tabular}{|c|c|}
\hline 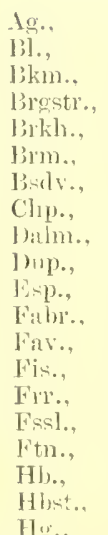 & 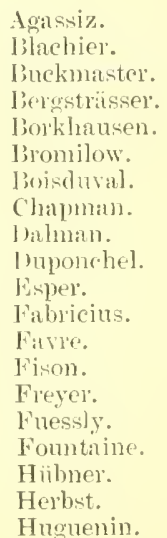 \\
\hline
\end{tabular}

H.-S., Herrich-Schäffer.

Hutn., Hufnagel.

L., Linneus.

tatr., Iatreille.

Led.. Lederer.

Linn., Lemann.

M.-1). Meyer-Diir.

()bth., Oberthion.

Uchs. Ochsenheimer.

li.-Brn., liowland-Biown.

limbr., Jiambur.

liott.. Liottemburg.

li.-s., lisgenbach-Stehlin.

s'chiff., Sichiffermiiller.

sipr., śpeyer.

Sitgr., Staudinger.

Stph., Stephens.

wh., Wheeler.

Wrehl., Wullschlegel.

Zll., Zeller.

Other names, which are shorter, or occur less frequently, are written in full. 




\section{The Butterflies of Switzerland and the Alps of Central Europe.}

\section{Super-Fam. HESPERIIDES.}

Dist. Char. great breadth of head, and of space between bases of antennar.

\section{Fam. HESPERIIDE.}

Sub-Fam. HESPERIIN.E.

Tribe Hespenm.

Genus, Carcharodus, //6. (Spilothyrus, I)up.).

Dist. Char. Series of 3 spots from costa nr. apex, and 3 separate spots on disc f.w., wh. appear transheent when held up to light.

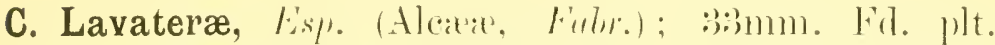
Starhyss verta; (?) hyb. l. full-ferl.

of with, $?$ without contal fold f.w.

Dist. Char. transparent spots large : orr. col. mp.s. lt.; nn.s. mnicolorons wh.

Loc. In Switz. only in S.W., but there not uncommon. Fusio

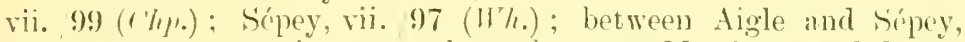
viii. 295 (.Imess); in most places between Martigny and Mörel (Far.), momting up to 5000ft, at Zermatt, and borisal, where it is ₹. ab., esp. from 2nd liefuge to Ganter Brirlge, vii.-viii. 97, 9s

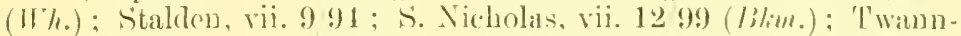
berg; St. Jlaise; Nenveville (Fry); leyrier, viii. 10, but v. lare (IBl.).

J)igne, vi. b. and m. 99, ab. (li.-limo); vii. (91 (l.mu.); liasses Alpes and Alpes Maritimes, gen. in dry torent beris and hot rocky

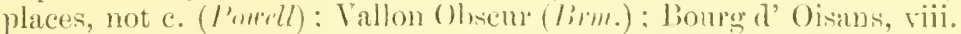

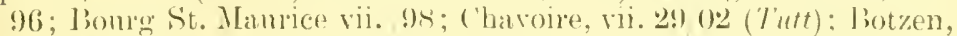

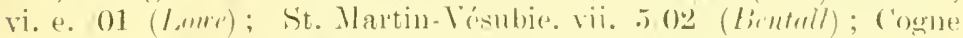
valley, viii. 94; Aostat to ('ommayemr, viii. (; )s. v. fine; Bohlip,

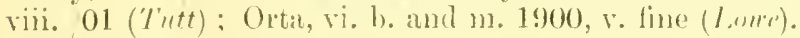

Directions of yar. (a.) sim. The Alpine specimens are finer and more clearly marked than those from further s.

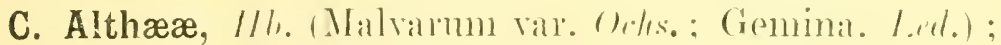
$30 \mathrm{~mm}$. lik. plt. valpious mallows; byl, 1, full-fed. $\vec{o}$ with, $f$ withont costal fold f.w. 
Dist. Char transparent spots larger thin ( A Alwn, the 2 exterior on dise with straight inn. edge: slight manwe tinge np.s. f.w. and conspicnons wh. longitudinal streaks at matg. m.s. b,w.

Loc. Yot mucommon in Rhone Talley in 2 broorls v.-vi., and rii.viii. Teytanx, r. 27.97; Sépey, Ne. (Hh.): Martigny, v. ab. (Far.); nю. Inden, v. al). (Km,ht); Pont de Nant, vij. 12; Sonzier, ri. 21: Ormont, viij. 15) (lil.) : Sion, viii. 1176 : Zinal, viij. 198 (R.- Sm.). ke. Petween the Schwam and IVeiss Liitschine (spro): Pilatns

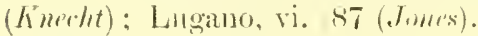

Digne, vi. 1:99) (li.-lin.); mr. (amnes, iij. e. iv. b. $98\left(\left(' / \mu^{\circ}\right)\right.$ :

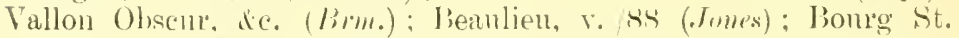

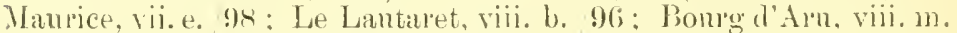

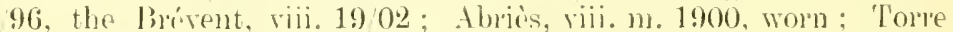

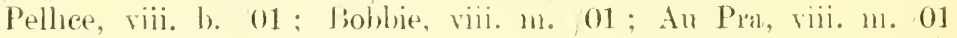
('l'utt) : Certosa di l'esio, lamp spots in mtms. (Tomis); Susa, vi. 18,02 (/mere) : Aosta, viii. 9s, helow P'ó St. Didier, viii. b. 98 (Tut1): Val Malenco, rii. 7, $1900($ li.-lim.): Lable of Como, viii. 96 ; Olgiate, fiii. 9;) (Miss Ftll.) : (ialolone, viii., 1, 1900 (dones); Orta, esp. Sitrona V'alley, vi. h. -i n1. 1900 (Jorre); lotzen (Kan'); Mendel Pass, vii. 9.) (I,mm.).

Directions of Yar. (a.) size, occasionally as small as $25 \mathrm{~mm}$.

(b). lightening of gral. col.

yar. Bætica, limlr. (Marubii, limbr.; loceifera, Yll.); much lighter, yell.-gr., one or two lt. bands h.w. : smaller than type.

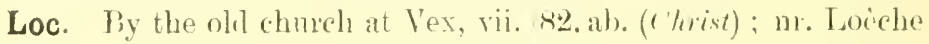
( linerlit).

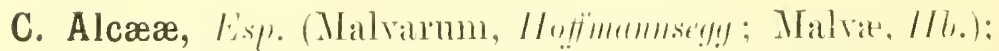
$30 \mathrm{~mm}$. Fil. plt. varions mallows; hyl. l. full-forl.

o with, $q$ withont costal fold f.w.

Dist Char. trimsparent spots v. small: 2 exterior on llise gen. crescentic: tinge of red-brn. II).s.

Loc. Lese local than the last hut gens, singly: 2 boods, iv.-Y.. and vii.-viii. All along the Rhone Valley (Fur.). e.\%, Jianson, v.

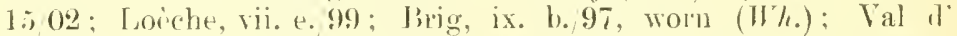
Amnivers, vit. 31 9T (li.-lim.); Mt. Janry, vi. 301900 (likm.); (ienera, Vevoles, viii.

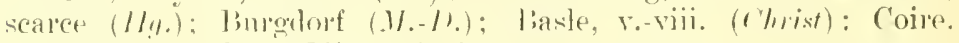
Rheinthal, and lower Mion (hillias).

(c)és-sur-Aix, viii. 11. 1900: Abrice, viii. 113. 1900, worn: liomrg

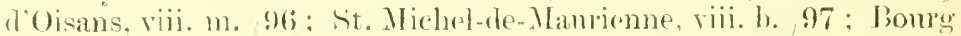

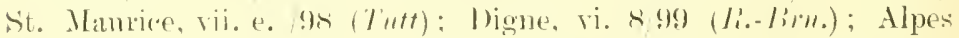
Maritines, jr-vand riij.-ix. (l'omell); ('ertosa di Pesio, damp spots in mtns., v.e. (Vurris); Susa, viii.m. 96 (Thtt); helow Iselle, vii.

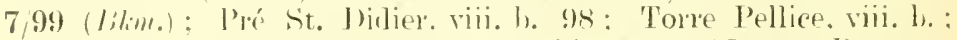

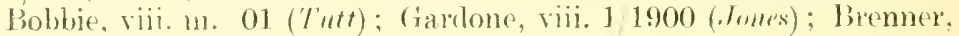
vii. e. $1900($ li.-lim. $)$.

Dircctions of Yar. (a.) distinctness of markings, esp. 1k. antemargl. hand up.s. f.w.

(1.) suore redtish-lim. sntfusion. 



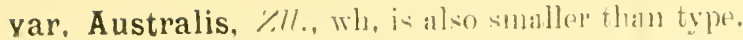

Loc. Alpes Maritimes (lim.) ; ('anne, ix, os; Silsa, viii, 97: Losta, viii. gs (l'utl).

(obs,-.Mr. Powell took a curious It, ab), in S.F. France, vili, 1102.

Genus Hesperia, L'alli. (Syrichthus, Riste.).

Obs, This is by far the most ditticult genus among the butterties, the same names having been in some cates applied to different forms, and each fresh nltempt at elncidation having often mate matters mone coufused than betore. This applies specially to the varions forms of Alveas and sermatulie. Iloreover. the sp. resemble one another in a gen. way so closely, and yet the individuals vary so greatly in a single sp.. that the difficulty is increased tenfold. In addition to ali this. no two collections seen to agrep in their separation of the sp. and vars., and I am, as yet, far from fepling the comparative certainty in

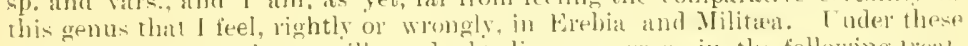
circumstances experience will no doubt discover erors in the following treat. ment of this gennm, and, in particular, it may be said that the localilies for the more obseme and uncertain forms are by no menns implicitly to bre redied on, as it is nometimes fur from certain to what exart forms they refer.

Preyailing col. Plk. or hlackish, with wh. spots, gen. more or less ()-shaped up.s. f.w.

Dist. Char. a hrush of hair on hind tibia of $\delta$.

o with, $q$ without a costal fold f.m.; also the of has and the $q$ has not a tuft of hair at the extremity of the body, and the o has gen. a temlency to he less spotted than the of, esp. h.W. It will not he necessaly to give these letails with the $\$ 1 \%$

*H. Sidæ, Fis. $: 30 \mathrm{~mm}$. Fd. plt. (and l.) nnknown.

Dist. Char. un.s. b.w. basal and el. bamels of lort. ol'.

Loc. Perhaps harlly within the region in S.F. France, but not uneommon nr. Hyères, e.t., v. 6. 12, de., 02, in Val ciapram (clopmir): liotzen (hami).

Directions of Var. (a.) tendrney to luecome lighter un. s. culnuinat-

ing in :

ab. Onopordi, $11 .$. .

H. Carthami, Ml\%. (Malrae, lisp.: Tessellum. (M.h.s.);

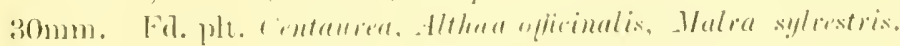

Dist. Char. Inl.s. It.. with inn. malr.. h.w. broully lighter. gen. whitish.

Loc. Ab, in plasese in the khone Valley in 2 broods iv--1. and

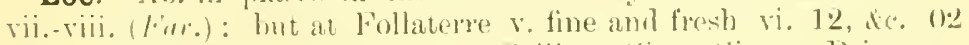
(II\%.): Sembrancher, Martigng. Sabillon, Sion, Sierse. Jirig. de.

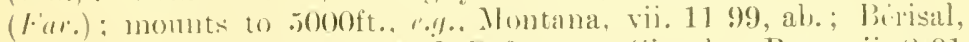

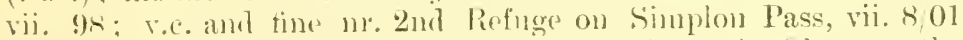
( $11 \%$ ) ; Riffel Al!, vii. 01 (L.mm.); (iadmen (liiit:rr); Olten, on the Schafmatt (Kuecht): Bieme, St. Blaise (t'mulrul). Tarasp (t'hrist), is the only loc. 1 can timl in the cirisons. but I think it must be found elsewhere. 
Diwne, vi. 1. 99 (Li.-lim.) : vii. 91 (Lmm.); Beanvizer, vi.-rii. (l'mell); c. in the intus. of the Alpes Maritimes (IFm.); Certosa di l'exis, vii. 92, ab. in (lamp spots (Norris); Sinsa, v. ab., vi. 2699

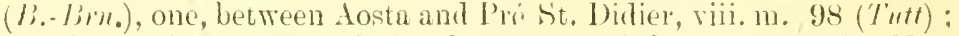
Chattillon, vi. 95 (Wiss Ftn.) ; Orta, v. e., vi. b. 1900 (I.rme) ; New baths of Pormio, rii. m. 1900, v. ab. (li,-lim.) ; Jotzen, vi. e. 01 (Itur) ; Mendel, vii. 95 ( / mm.).

Directions of Var. (a.) Size: [my smallest o is $26 m m$, my largest $q 34 \mathrm{~mm}$.

(b.) Size of wh. spots up. s.

yar. Yalesiaca, Strelier; with smaller spots f.w. and none, or scarcely any, h.w. ; less dusted with gr.

Loc. The Valais and S. Tyrol (St!r.); Martigny, Fully, Sion, Sierre, \&c., with type (Far.).

Obs.-According to Frey this would appenr to be the form of the 1st brood in Valais, but I have not met with it. The usual form there from vi. onwards is v. large, the $\delta$ v. grey, and with large spots in both sexes, the o having more, and the \& not less than ustal on h.w. This is certainly the case everywhere that I have taken it; e.\%., Follaterye. Montana, and Refuge on the Simplon, de.

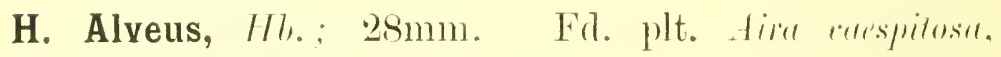
r'otentilla fivinila, ic.; hyb. ov.

Dist. Char. un.s. h.w. lt. cl. band, not projecting inwards, basal spot not isolated, inn. marg. broadly darkish.

Loc. The alpine form according to Frey, but not exclusively so. Basle, Liestal (c'hrist); Hugelherg (l'ie!l); Jingstlen Alp

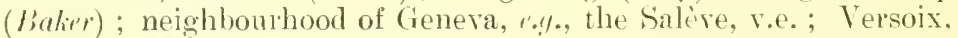
viii. 16; Meyrin, vii. 18, Ac. (lil.); c. in the Valais and the Grisons, e.\%., Montana, vii. 1199 (II\%.) : Arpilles, Bovine, Locicheles-bains, Stalden, ice. (Fu.); Riffel Alp, vii. 01 (Lmm.); Campfer, on dry slopes, c. (.fomes); Dischmathal, vi. 2701 : lirusio, vii. 18/01 (Fis.), ice.

Gen. distributer over the rest of the region; 2 lroods at lower, 1 at higher elevations.

Directions of Yar. (a.) number and size of wh. spots up. s.

yar. Onopordi, limbl.; with numerous large spots, a large form; un. s. pale.

Loc. Bortel Alp; Mattmark, Saas, rii. 1.5-2s (dr. Jmmer); Evolena, Daros (li.-Y.); the Jura (1/.-ll.).

Jigne, Beauveryer, vii.-viii. (I'wuell); 'I'horenc, ab. (.Millier').

var. Cirsii, limbr.; with larme spots; of small size; grt. col. un. s. reel, or brownish-gr'.

Loc. Basle ( \%rist); the Pechburg and Sant du Moubs (li.-s.); Burgdorf, Resi nr. Solenre, vii. and viii.-ix. (./.-/.); l'aren (('hrist); Jäirenfallen Alp, vii.-viii.; Salquenen (Far.); Martigny $\left(1 l^{r}\right.$ selll.).

Digne, viii. Alpes Maritimes (/'orrll); above St. Martin Vesubie, rii. b. (limtull). 


yar Conyzæ, linimin: spots v, wh. ; 111. . palle.

Loc. Dime vii.-viii. (l'urmll).

yal. Fritillum, Tritshle': with larger spots up. s. than type, and much larger spots un.s. h.w.

Loc. According to Frey the usual form of the plains but not exclusively so. Zïrich (Froy); Trift Alp (L..S.); (Gadmen ('/rist); on the slopes at Weissenburo, not scarce (I/!.); Morteratsch Glacien, viii. 101 (Fis.); c, jin the Rhone Valley: Fully, Branson, J'artigny, Brig, ic. (far.); Sierre (II\%.). 2 hroods in the plain ri. and viii.; 1 in the mtns. (Frey).

yar. Carlinæ, Pimbr.; with r. small spots up. s.

Loc. The Gemmi, ( $F a r)$ : Loèche-les-Bains, vii. 99 (lísa); Le Lautaret, vii. 30, viii. 5 (Tutt).

Obs.-Cirsii, M..D. is $v$. differently described. It is said to be as large as the type, and to be conspicuously dusted with rell. ; spots on up.s. h.w. almost wanting; un. s. so lt. that it might be taken for Carthami. It is a $\mathrm{S}$. form. (Frey, Lepidopteren der Schweiz, p. 51, note.) The name has no business to be applied to this form if it be a var. of Alvers. I am inelined to think it a torm of Carthami.

H. Serratulæ, Rimhr.; 25mm. Fd. plt. tire mentumn and Potentilla fivinila.

Dist. Char. mn.s. h.w. romolish hasal wh. spot nr. costa isuluted; cl. lt. band not projecting towarls base; inn. marg. mn... h.w. darkish.

Loc. Surenen ( 1 hrist) ; Engstlen Alp (Balire); Monnetier, ri. 2 ; Pont de Nant, vii. ( $\mathrm{Bl}$. ) ; the Jura, r.!., St. Georges, vi. e. 02 , c. $(I \%$ \% ; Branson, Jemr-brîlée, from Sierre to Kinal, from Visp

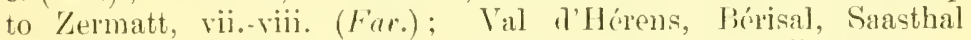
(li.-lim.); T'isch, vii. 99 (limsa); Andemmatt, rii. s6, r.c. (Jums) ; Rosegg Glacier, viii. 301 (F/s.); nr. lake at st. Moritz, vii. e. ( Virlulswint).

Directions of Yar. (a.) Size of spots np. s., gren. small, sometimes obsolescent, culminating in :

ab. Cæca, frr. (with basal spot less isolated), in wh. there alle none, or v. fer and small.

Loc. l'ontresinat. vii. s.) (I.mm.) ; Térisal (I\% : Engstlen Alp

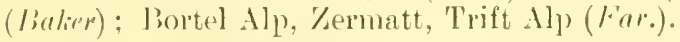

ab. Tarasoides, //imer, with spots np. s. conflnent.

\section{H. Cacaliæ. limlu. : $28 m m$. Fil. plt. (and l.) muknown.}

Dist. Char. un.s. h.w. cl. lt. band projecting inwards in millle; hasal spot isolated; mn.s. f.w. v. washed out and indistinct.

Loc. (ien. ab. in the high alps from Martigny to the far sirle of the Tyrol, vi.-viii., e./., Dranse Valley below Orsieres (lialier); Arpilles; lovine; Bortel Alp, v. ab.; by Fiffel Alp Hotel, vii. 2602 , v. ab.; the Grinsel, i.e. (Far.); ab. in Upper Engartine.

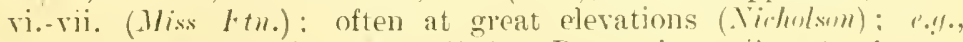

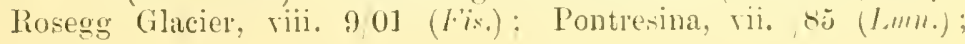




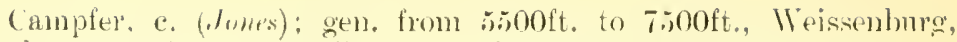

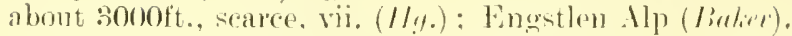

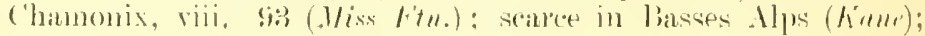
al, at Pic de l'Jigle, Alpes Maritines (lim.).

Directions of Yar. (a.) amount of wh. spots up. s. f.w., gon. v. slight: h.w. alnost withont marks.

(b.) depth of grd. col. ip. s.

H. Andromedæ, Wallithll : 2smm. Fr. plt. (and l.) mknown.

Dist. Char. 111. ‥ h.w. 1t. cl. hand projecting inwarts as in Cacalist, but on mp. s. f.w. :) short wh. lines under lasal part of Q-mark: fringe sharply detined.

Loc. Not on the Jura or the W. Alps. Mranse Valley, below Orsieres (Bnlar): Pont de Jant, vii. 12, scarce (l:l.); (iemmi, IIr. the Schwarzbach, vii. 9!) (Lima); Nattmark (lirit:re); below \%rmatt, vi. (l'imbler) ; liovine (tor.); Andermatt, vi. $6 / 86$, c.

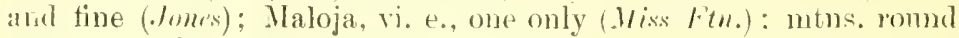
lereniin ; Albula Pass, vi. b.-viii. b. (Firy).

Stelvio: Franzenhöhe mol 1000ft. above (Fiey); Certosa di Pesio, not rare in Tal Wagnareis, vi. e. 92 (Norris); Allos, vii. 15-18,99) ( l'wrrll).

H. Centaureæ, limle: :30mm. Fil. plt. (and l.) inknown.

Dist. Char. m. s. h.w. zigzag markings nr. fringe; grl. col. up. s. browne" than last sp.

Loc. Steinesuthal, nr. Périsal, vi.-vii. (licit:re).

H. Malyæ, l. (Alveolus, //h.): 2:3mm. Fd. plt.

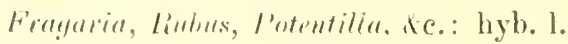

Dist. Char. "1).s. wh. spots larger and more conspicnous than in any other sp. in proportion to size.

Loc. Gien. distributed over the region, and gen. c., iv.-vi., and all hiober elevations to vii. m., r..., Strlvio, mr. T'rafoi (li.-lim.); found up to $6 i$ (o) $0 \mathrm{ft}$.

Directions of Yar. (a.) confluence of spots up.s.

ab. Fasciata, Tutt: in which wh. spots b.w. unite into a cl. band.

ab. Intermedia, shilds: in which wh. spots f.w. are conthent and banderl. hut not forming a large blotch.

ab. Taras, lir/ste: in which wh. spots f.w., and sometimes h.w. also, join into a large wh. patch.

Loc. Anywhere with type; $\because !$. , Veytanx $\left(\| h_{0}\right)$; Berne, v. $7 / 9:$; (Flem!n!f) : Weissenburg (/1\%.); Martigny; Sion; Sépey; (iryon (Fur.); Aigle, iv. 28:03 (H\%.): not mncommon at Mometier, v. 25, 2k: vi, $10(\mathrm{lil})$.

(b.) dinninntion of wh. wn, s, h. w. 


ab. Malyoides, lilwes: with un.s. h. w. brownish.

Loc. Alpes Maritimes. vii.-viii. (l'mell). [This would seem to imply a resulat end brood.

Genus, Pyrgus, $/ 1 /$.

Prexailing col. Milk. or blackish with wh. of whitish spots.

Dist. Char. absence of brush of hairs on hind tihia in $\delta$.

$o$ and $q$ differ otherwise as in Hesperia.

P. Tessellum, //l. : :31mm. Fil. plt. (and l.) n11kilown.

Dist. Char. 11p.s. f.w. ¿2 oblong wh. spots under the distorterl (2-mark, one below the other, forming a sfluare: 2 distin't lows of wh. spots h.w.

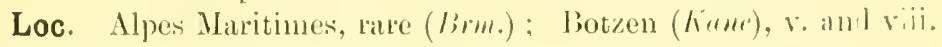
Directions of Yar. (a.) rrot. col. mp. s. in 3 sometimes approaching lighter gril. col. of ?

(1).) depth of gred. col. Im1. s. h. w.

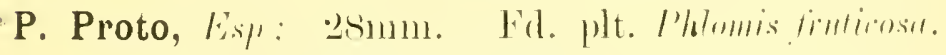
o with, o withhout gr'. dusting.

Dist. Char. I11.s. h.w: : rather indistinct narow lt. hands, the el. the most distinct; spots 11 \%: $s$. and fringe dirty gollowish.

Loc. Digne, not above zoooft. vi.-vii. (I'merll).

Directions of Yar. (a.) gril. col. 11n. $\therefore$. h.w. valying between yell.-gre and red-brin.

P. Orbifer, 1/1. (Encrate, Frr.): 2Tmme lid. plt. (and l.) unknown.

Dist. Char. In. $\therefore$. h.w. bisil wh. spot and cl. biunel of wh. spots rumend.

Loc. S. 'lyol. r. ant vii. (hime).

Directions of Yar. (a.) mirl. col. w1. s. h.u. varging from yell.br'n. to olivergrin.

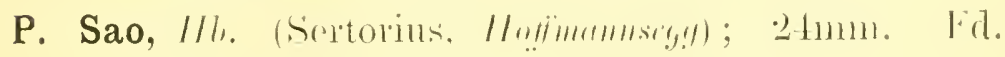

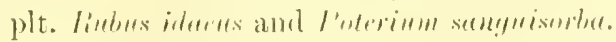

Dist. Char. Bot wh. spate from apex in fringe f.w. nutch widep than the others: It. c]. band mus. S. h.ll. projects towamls hatse at costa.

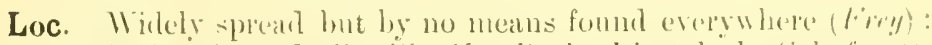

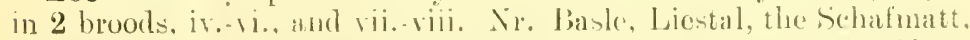

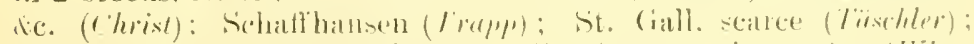

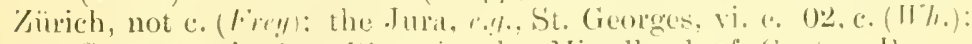
St. Cergues, vi. $26(l i l$.$) ; in the Mittelland of Cinton lierne:$ 
Oberhaslithal; hills nr. Burogdorf $(F, r y)$; Weissenburg, v.rariable (Hy.) ; Justisthal (Fis.); Weggis, viii. 96 (Tutt) ; Mt. Balry, vi. e. 1900 ; Rossinières, vii. 2, 1900 ; Comballaz, vi. 1599 (likm.) ; gen. distributed from Lausanne up the Rhone Valley; Veytanx (II\%.) ; Martigny ; vineyards of Mt. Ravoire; Fully ; Sion; Sierre; Niouc, de. (Far.) ; Brig, viii. 374 (li.-Bru.) ; rising to over soooft. at Zelmatt, vii. 01 (Lmn.); and Bérisal, viii. 197 (Li.-liru.); Loeche-les-bains; St. Nicholas ( $\mathrm{Fu}$.); Stalden, vii. 9.94 (lilim.); 11. Bergin ( $/$ lll.); Lower Engadine (Killias); Piz Okel nu. Come (f atlise-h); c. S. of the Alps, $e . \%$, San Stefano, r. 22 (Muyer); Gandria, viii. 14: Mendrisio, viii. 1502 (Fi.s.) ; Simplon, vii. 99; Locarno, vi. 99 ; ir. 00 (Twt), dec.

Savore, $\iota \%$, le Coin, v. 11 ; viii. 16 ; Monnetier, vi. 2 ; viii. 10 (lil.) ; (iresy-sul-Aix, v. 97 ; viii. 11. 1900 ; the bréent, viii. 1802 ; bonl: St. Mannice, vii. 9s; St. Michel de Maurienne, viii. 97; Lal'che, vii. e. 1900; Abries, viii. 1n. 1900 (Tutt); c. at Digne, vi. b. 99); and on the Donrbes, ir. s 02 (li.-liru.); Nice, Cannes, and mtns. of Alpes Maritines (Rmr.); Cogne, viii. 94; Conrmayeur, e.vii. 94; An I'ra, 11. viii. 01; Cortina, viii. 95 (T'utt); Mendel, vii. 95 (l mu.). Directions of Yar. (a.) gril. col. up.s. (always a redder or purpler blk. than other sp.).

(b.) gred. col. un. s. h.w. v. variable, rich renbru., prp. - bru., yell.-brn., or brownishgine

ab. Eucrate, (ks.

(c.) smaller, with 1t. 11n. s.

Loc. Alpes Maritimes ( $\mathrm{B}$ rm.).

\section{Genus, Nisoniades, $1 / l$.}

Prevailing col. darkish bru.

of with, $q$ without a costal fold, f.w. containing lighter scales.

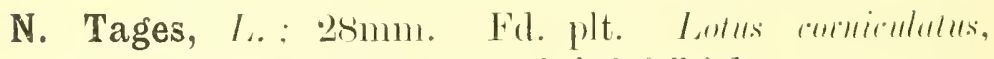

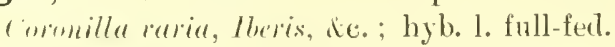

Dist. Char. a low of v. small wh. spots close to fringe up. and un. s. f.w. and h.w.

Loc. Gen. distributed and c. ir.-v., and vii.-viii. (My earliest Aate is Veytanx iii. 29 99): mounts up to about 5500 lit. ; not r.c. in the S.E. alps of France ( $l$ 'urell).

Direstions of Yar. (a.) distinctuess of markings; sometimes almost obsolete.

ab. Approximata, Lmer. (So called because approaching the Greek vil. ('uicolor.)

Loc. Aigle, iv. 03 (Sloper) ; Susa, vi. e. 02 (l.mer).

(l.) col. of lighter cl. band up.s. f.r., bia., or., or slightly redalish.

(c.) extent of inner line of wh. dots up.s. f.w., varying from a single spot on costa to a complete series. 


Sub-Fam. l'AMPHILINA.

Tribe Pasinulud.

Genus, Pamphila, librr.

Prevailing col. or.--brn.

Dist. Char. III. s. h.w. spots lighter than grd. col.

P. Sylvanus, lisp.: :32mm. Fal. plt. l.⿲:ulu pilusu, l'esture, l'ua, ile.; liyb. l.

of with, f without hllk. transverse streak up.s. f.w.

Dist. Char. 111, s. h.w. spots yell, and inconspicuons.

Loc. (ien. distributed and c. mp to 6.j00ft. vi.-viii.

Directions of Var. (a.) size; from 25-35nmm.

(b.) depth of int. col.; specimens from the untus. gen. darker.

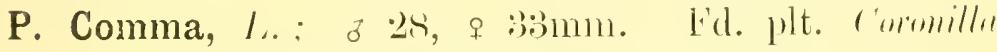
ratio, and rarious grasses: hyb. $l$.

o with, o without blli, transverse streati up.s. f.w.

Dist. Char. un.s. h.w. spots conspicuous and silery wh.

Loc. (ien. distributed and c. in the mtns. 11 ) to $7500 \mathrm{ft}$. and by no means uncommon at lower elevations, vii.-riii.

Directions of Yar. (it.) brigliter col. un.s. h.w. culuminating in:

ab. Catena, stır.; in wh. they are vivid gru. as also apex f.w. u11...; np.... diaker than type.

Loc. High mins.. e.!. the Simplon, magnificent examples o and $q\left(1 . i_{0}\right)$; Salas lie (lio-lirn.

(b.) darliening of up.s. grd. col. and markings.

var. (?) Alpina, liuth (Entomologist).

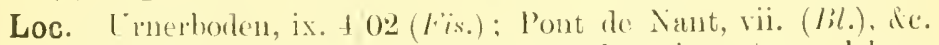
The darker forms, however, are not confincel to the nutns.; I have seen $Y$. ılk. specimens from Mendrisio, vii. 201 ( Fi i..).

(c.) spots u11.s. h.w. yetl. instead of wh.

ab. Flava, Thtt. (Still guite elistinguishable fro un grt. col.).

Genus, Thymelicus, $/ / 1$.

Prevailing col. ol.-lym.

Dist. Char. absence of spots $211 . \mathrm{s} . \mathrm{h} . \mathrm{W}$.

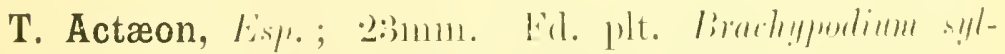

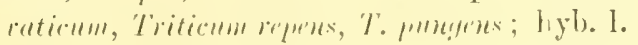

o with, o without longish blk. streak up.s. f.w.

Dist. Char. up.s. greenish tinge.

Loc. I. local, often confinerl to r. small an as, vii.-riii.; Veyrier, vii. 1. (lil.); sierre, and several places in the Pfynwald, one or two 
heing by the main road, vii. 11. 99; Brig, right bank of Rhone, below the hridge, ix. b. 9r, worn ( $1 h^{\circ}$.) : Nartigny, abore Plan Céricier: lsetween Aigle and Sépey: Arpilles; Zernate (lor.). This last is considerably above the usual limit.l Pasle

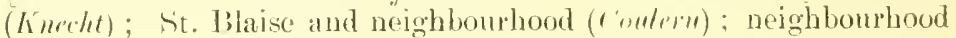
of St. Gall, but scarce (Thwhler): wide spread arouml 'Tarasp (Killias): Weissenburg, up to $3300 f$ t. (I/\%).

Between Annecy and Charoile, r. ab., vii. e. 02 ; (résy-sur-Aix. vii. e. 98 (Jutt); Digne, vi. b. $99\left(R_{\text {. }}-\right.$ lim.) : Alpes Maritines, gene. distributed (l'mull): dosta, viii. In. 9s (Tutt).

Directions of Yar. (a.) Amount of marking in 3 up.s. 1.W.; sometines micolonoms, sometines with the or. costal streak and fan-shaped row of spots as well marker as in the ?

(b.) gred. col. 11n.s. h.w.; gen. nnicolorous, but greener gr. specimens have an or. anal patch.

T. Lineola, (ths. (Virgula, //h.): 2(imm. Fid. plt. Tritichm, de. : hyl. or.

of with, $q$ without short blk. streak up.s. f.w.

Dist. Char. sulfused blk. border up.s., the outer end of the nerrues being ren. conspicuous; further distinguished from Actiron by absence of greenish tinge up.s., and from Flavus ('Thanuas) by absence of grm. fiom apex f.w. un.s., and of brt. or. patch at anal ang. h.w. un.s.

Loc. V. ah. in the meadows and roads in Valais up to more than soooft. ( $\left.1 \mathrm{r}^{\prime} \%\right)$. In my experience ab. whore it occurs, but local. Sépey, vii. 97 (11\%.); the Jurd (Fry); scarce in the lowlands,

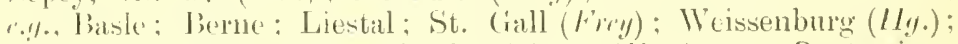
Ciondo, rii. 1702 (Fis.); c. in the (irisons (Fry); c.l., Pontresina: bial Alvenen; l)isentis (/mm.); Thusis, viii. 9\% (Miss Ftu.): Brusio, vii. 1301 (Fis.); Fusio, vi. /)!); Guatda, vii. 1900 ( ( hj.). (irrésy-sur-Aix, vii. e. 9 s: viii. m. 1900, worn; Abries, riii., m. 1900 ; Larche, vii. 1900 ; Megreve, viii. 02, v. ab. (T'utt): Matengnaga, vil. 96 (.Miss Ftu.); Digne, vi. 90, vii. 91 (Lmm); Alpes Maritimes, st. Martin Vésubie, and many other places, but l'ather local, and not v.c., vi.-vii. (l'urrll); Commayenr, vii. 94; viij. 98 $(T$ '

Directions of Yar. (a.) lighter grel. col. up.s.

ab. Pallida, Tiutt; a pale straw-col. ab. found occasionally in looth sexes.

ab. I Semicolon, st!r.: wh. has a short blk. streak below the usmal (androconial) one, standing ont distinctly on the paler grd. col. All my of specimens show some slight traces of this streati.

(b.) increase in breadth of borter, culninating in :

ab. Ludoviciæe, Molrille; wh. has also blk, apes. and inn. matr. 1117.5 .6 .11 .

Loc. Haut Valais (.t!.); Simplon ('lutt). 


T. Flavus, Rrimm. ('Thammas. Hufir.: Tinea, Fillro): 28mun. Fil. plt. urasses; hyb. l. (? sometimes of.)

o with, $q$ without longish blk. streak 11 p.s. f.w.

Dist. Char. mn.s. I.w. greenish tinge at alpex, also on mn.s. h.w. exe. anal ang.

Loc. gen. distributed and e. "1] to $4000 \mathrm{ft}$. : in some places, ".\%, Cermatt, higher, vi.-viii.

Very constant: a lalke form at Villach $(I, \mathrm{~mm}$.).

Tribe CrCLopidi.

Genus, Carterocephalus, lid.

Prexailing col. brn. and yell.

Dist. Char. up.s. h.w. yell. spots on brn.

C. Palæmon, P'ullus (Paniscus, Falur.: Brontes, Hl.) ; $27 \mathrm{~mm}$.; Fd. plt. Plantain and grasses; hyb. 1.

Body of $q$ more pointed than that of $\delta$.

Dist. Char. Dk. gril. col. f.w.: with yell.-hrn. spots.

Loc. Gen. distributer in grassy woorls, lunt v, selitom c.; r. m. vi.-vii. b. ; in the lowlants and hills, and in some places reaching to the mtns., e.... Forclas; Glacier de Trient, c. (Far.); Veytanx, v. and vi. 98 and is. 28,99 ; Sépey, vi. e./97. Mtt. Barry, vi. 94 (Wh.): Weissenburg, c. up to $3300 \mathrm{ft}$. (/1\%): Les Plans, vi. 16! (5) (Fis.); Turtmannthal, vi. 2099 (likm.); Orsières (lialirr); Collombière de Fully ; Sierre, dc. (Far.) : Brumen; Andernatt, scaree (.tomes) ; Axenstrasse, v. 17/88 (/huthinsm) : nr. Lake of Lucorne: Fluelathal, vi. 27; Dischmathal, vi. 28; Flims, vi. 3001 (Fis.): Davos (Killies:) ; Maloja, vi. e. 95 (Miss F'tn.).

Val de Lantosque (Milliere) : Tal Anzasen: Susa, vi. e. /02 (Jum): Pejo, vii. /95 (Lmm.).

Directions of Var. (a.) size of sprots up.s. esp. h.w., sometimes almost obsolete.

[Obs.-The 2 specimens mentioned by lirey from the Maloja, vii, e. /65 arm of this form, but by no means an extreme case.

*C. Sylvius, Kmmll: $30 \mathrm{~mm}$. Fil. plt. grasses; hyb. l. o with much nore bru. f. anch h.w. than of.

Dist. Char. yell. grd. col, with tlk. matkings f.w.; h.w. th. with large yell. spots.

Loc. Nitns. of Fenestrellin, rare (ham).

Genus, Heteropterus, Immiril.

H. Morpheus, I'ullus (Steropes. Silliff: : Alacinthus, Fabr.: Speculum, Sillumli) : 36imm. Fil. plt. gralsses : hyb. 1.

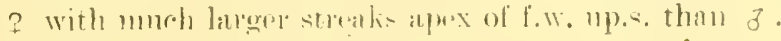


Dist. Char. mn... h.w. 12 liurge yellowish spots: (np.s: dk. hrn).

Loc. Below (Hiornieo, and S. side of Mte. Cenere, $180+$ (Meissnet); Giubiasco, nr. Magarlino, vii./57, not scarce (Tiall'). I can find no later dates.

CObs.-Kane gives vi. e. vii., and observes that it "must be beaten out of foliage in damp glades of wods." Millière gives "heights of Berthémont," on wh. Powell remarks (in lit.) that he hats never taken it there himself, nor has any collector of his acquaintarce. It seems a most mulikely loc.]

Directions of Yar. (a.) decrease in size of spots in o up.s. f.w.; sometimes quite disapperaing.

\section{Super-Fam. PAPILIONIDES.}

Division LYCENIDA.

Fam. Lycænidæ.

Tribe Thestorun.

Genus, Thestor, $/ 1 /$.

*T. Ballus, Finbr: 2Nmm. Fd. plt. Lotus hispielus, lyyl. p.

o witlout. \& with large or. blotels up... f.w.

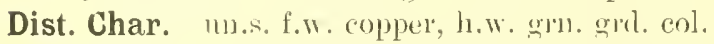

Loc. Perhaps harlly comes into the region, but Millière gives waste land of Vallanris: ab. 11r. Hyeres: r.!., Col de Serre, iii. 18 ;

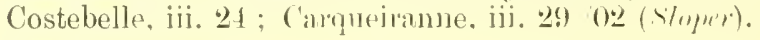

Tribe ('hrysol'hanid).

Genus, Chrysophanus, $1 / 1 \%$.

Prevailing col. copper (or brn.), often with more or less prp. reflections; un.s. with eye-spots: hyb. l. (exc. Alriphemen).

C. Virgaureæ, I. : :30mm. Fil. plt. Rimmer artesu. Ri.

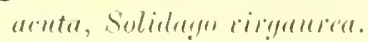

Brt. or.-copper, o withont, o with munerous blk. spots on dise f. and h.w'

Dist. Char. intermpted line of wh. dets an distus m.... h.w.

Loc. I. occasionally in the lower valleys,.$\%$, Aigle, 1 J, worn, vii.e. 97 : Martigny $(11 \%$.) ; hut gen. ab. in Siwitz. at the pine forest zone. wap. 111. strams and in most places, vii. e. and viii.; Juri.

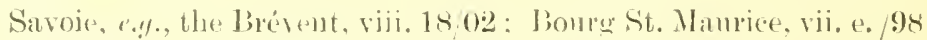

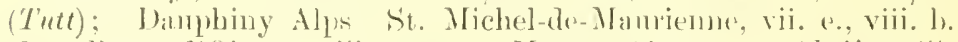

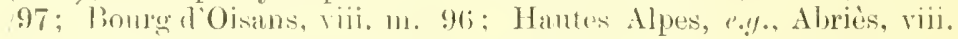

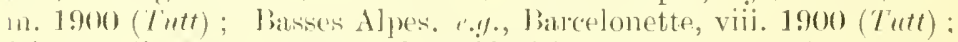
l)igne, vii. 91 (Lmu.); Alpes Miritimes, up to 500oft. (lim.):

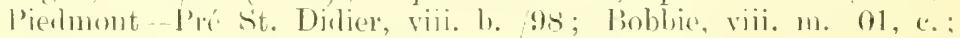

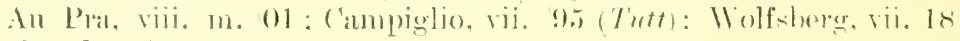
, 97 (Limll.).

Directions of Yar. (a.) si\% : from 21 - : $: 311111$.

(h.) un.s. f.w., distinctuess and continnity of wh. IIIle. 


(c.) $\&$, wh. line appearing on up.s.

(d.) o , breath of blk. borter. v. rarely with three blk. spots nr. apex, ıp).s. f. 1 .

(c) $f$, loss of brilliance of grt. col., culminatjng in :

yar. Zermattensis, Fallon, with grt. col. yell.-bin.

Loc. Zermatt valley, vii. 01 (l,mm.); liérisal, viii. 98, ab. (Wh.) : Kinal, vii. 31 and viii. 94 (li.-lim.); Serluiin, viii. 27/02 (Fis.): Campfer, v. ah. (.momes) ; Sibasthal, and Maderunerthal (Kame). Hitherto consitered a o var. but a corresponding o witl metallic buff ord.-col. Was taken at the Riffel Alp, vi. 2s 02 , by Chne. Favre.

[Obs.-On the S. side of the Simplon Pass, e.g., Simplon Village, all the of are of the type, on the N. site, and gen. in the other valleys mentioned, all are of the var. A transitional form occurs with the var. at Sedrun (Fis.).]

Dauphiny Alps-St. Michel-de-Maurienne, vii, e. 97; La Grave, viii. 5-13/96; Bourg d'Aru, viii. m. 96; Hantes Alpes-luarche, vii. e. 1900 ; Abriès, viii. b. 1900 ; l'iedmont-Commayent, viii. e. $/ 94$; Cogne, viii. 7-1294; Pró St. Dirlier, viii. b. Is (Thtt). TThe Cogne specimens are the nearest to the small and pale specimens from Kermatt; those from the other localitiesare rather transitional ( 1 ntt).

Directions of Var. (b.) and (c.) as above.

(f.) up.s. f.w. levelopment of blls. spots into strealis.

[Obs.-This development is occasionally seen, un.s., in many of the I terantiti : ef. also ('. Hippothoi?.]

C. (Dispar. Henerth) var. Rutilus, Himelury (Hippothori. Hb.) ; :somm. Hd. plt. sorrel and bistort.

Iirt. copper red, of without, \& with row of blli, spots up... f.w. Dist. Char. un.s. h.w. clear gr, with hluish base.

Loc. Certosa di Pesio, ronnd the reat springs at Beinette, vii. 2992 (Nomis): Kan also gives Savole, and Val Tellina. In these locs., presmuably both broods, v.e.-vi. e. and vii. e.-ix. would ocenr: further N., in Germany, there is but one. vii.

Directions of Var. (a.) $\delta$, more ") less blk. spots ont. marer. up.s. h.w.

(i.) $\&$, up.s. h.w. more or less covered with brin.

C. Thersamon, lisp. (Xanthe. I/l.); 2:3mm. lit. plt. spartium sceprerium.

13rt. or., \& without, $q$ with spots on dise of f.w. up.s. $x$. infici (a.) ].

Dist. Char. o, hrn. sluding on ıp.s. h.w.: q brt. gre. col., extending to ont. miurg. mp.s. f.w.

Loc. Piedmont in open woollandi on S. side of Alps; also

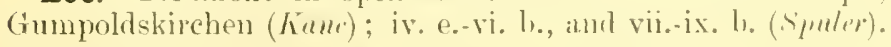

Directions of Yar. (a.) extent w wh. spots of $\mathrm{nn.s}$, are visible ah⿻上丨. exp. in 3 . 
(b.) mpe reflection ml. ont. marg. np.s. h.w. in $\delta$.

(c.) a slender" "tail" h.w. constitnting:

var. Omphale, hlu!.

Loc. Tal de Lantos!ne, from 3280-4920ft., replacing type (Hillie'r).

[Obs.--There seems no reason why this sp. should not occur in Tessin and the S, of the Grisons.

C. Hippothoë, 1. (Emrrilice, lintt.: ('hryseis. Pritho):

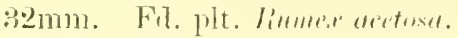

a juddy copper, o ditto with rark spots f.w.: h.w. lnow. with copper ante-ruaryl. hand.

Dist. Char. m1... f.w. with dnll rerl.-ol. el. area, with suall eye-spots.

Loc. Widely spreat, lnt local; gen. in marshy spots. esp. damp meadows. Vevtunx, vi. b. 97; Canx, vi. 97 (I\%.); Villass-smrBex, vii. 0.2 (./ 1 ss) ; Lorche-les-bains, Naters, Mayenwand (Far.);

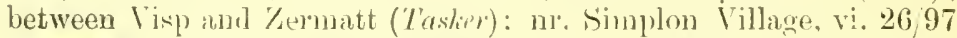
(Postans): lehind the Hotel Mt. liary, vi. P. 9ৎ, c. (W\%.); same place, vi. 28-:30, 1900, worn (l;km.) : Mïren, vii. e. 1900 , c. (1Ih.);

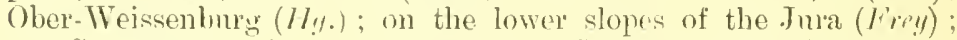
P.\%., St. (ieorges, ri. e. 02 (Wh.); St. ('ploucs, vi. 25 (lil.) ; rare in N. Switz. (Kam) ; apt to risappear when its hatunts are rinined.

S. Tyrol, vii. 95 (Lmm.); Savoie, (imanl Sillive, vi. 24; vii. 4 ; le Reculet, vi. 26 and Mommetier, v. 30 (l/l.).

Directions of Yar. (a.) $\delta$, extent of deep pres. suffusion up.s. l.w.

(b.) more or less conspicnons copper hand in this suffusion, like $q$.

(c.) $q$, copper of f.w. up.s. more or less invaded by brn., enlminating in :

yar. Eurybia, (Ihs. (Eurydice, $/ / h$.) ; o has far less prp.; the blk. dise. spot up.s. f.w. almost always absent; $q$ only v. slight tinge of copper ; dull or. cl. area un.s. f.w. v. indistinct both in $ð$ and $q$.

Loc. The usual mtn. form (but at Mürren, even in the Blumenthal, only the type is found). In some places both forms fly, e.g., Engelberg, ab. (Batier) ; above Nax (christ); so also in the Arve Valley nr. Chamonix (baliev); above Abries, viii. In. 1900, v. Worn (Tutt). Nuch less local than the type and by no means confined to damp or marshy places: from the Valais to the Stelvio, rii.-viii.. $\because ! .$, Simplon road, v. ab. from Ganter Bricige to 5 th Refuge (11\%.); Oberalp, viii. 95, Andermatt, viii. 95 ( $1 / \% \%)$; Matmark and Saasthal, viii. b., a small form; Arolla up to 7000ft. viii. 25:96, Rc. (R.-Rm.); and gen. in the high Valaisian valleys; also in those of the Grisons; e.t., Pontresina, vii. 85 (Lmm.); Davos, viii. 2, 1900; Fusio, rii. h. 1900; Gnarda, vii. e. $1900\left(\mathrm{C}^{\mathrm{r}} \mathrm{\gamma}\right.$.). Splugen, IV. sirle, vii. స, 1900 (R.-lim.), \&c., \&c. Susten, Handeck, 


Urserenthal, ace (haur); (irimsel, Alcts'h Glacier (liar.): Jim (likin.), ile.

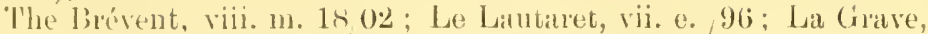
viii. b. 96: Larche, vii. e. 1900; Abries, viii. b. 1900 ('tutt); St. Martin Vésubie (Brm.); ('ogne, viii. 11. 91; Jobbie, viii. 11./01, worn ('T'utt); Maneugnaga, vii. 16-20, 1900; Campiglio, vii. $/ 95$ $(1 / h)^{\prime}$ ): Salzburor and Berchtesgaden, vi. e. 1900 (Lang).

The extreme form of this val, is named:

ab. \& Nigra, Far. : v. dk. brn. withont a tonch of or.; blk, dise. spots up.s. f.w. v. distinct.

Loc. Mt. Chemin, Martigny (Far.); Hérisal (Wh.).

forming:

(d.) tenclency of hik. spots un.s. to coalesce,

ab. Confluens, Gerhard: sometimes on one side only.

(e.) diminution in size; of fulvous.

ab. Stieberi, rewheril; a N. form, but repurted from Engelberg (liatier).

Obs.-In Mr. Fison"s collection are: $;$-pecinens without mathing on the left f.w. un.s.; it $\delta$ of type, and \& and \& var. Firylin. Mr. Lowe describes a \& var. Eurylin trom Fingelberg, vii. 6/01, as being of 3 niform dk. bron. with a slight prp. glaze, exc. a hit. or. spot in centre of f.w., throwing into strong relief the 2 large blk. dise. spots ; faint traces of ante-margl. row of spots $t$. and h.w. : 110 or. margl. band h.w., making the wh. fringe $x$. conspicuous.

C. Alciphron, liett. (Hipponoë, Lisp. : Lampetii. H/.o); $33 \mathrm{~mm}$. Fat plt. linmer aretesa: hyb. or.

3, copper sufficerl with prp., often wiving a brownish appearance, 9 lim.

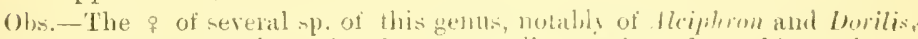
differs extremely from the of in shape, as well as rol, and mathings, the of haviog an angulay outline, eaps. h.w.

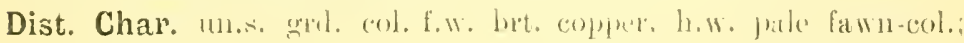
darker in o

Loc. 1. rarely wet with in switz: Engetbery, vii. (Fring): Fiesch (not Viege), vi. e. (Timpl); c. at the upper end of the Val bregaglia, vi. e. (liavilgher).

Certosa di Pesio, r. c. (Norris).

Directions of Yar. (a.) ठ, dininution in cxtent of suffusion.

obs,-In Geneva I niversity IIusenm is a 5 speeimen from Hyères with only al low of prp. spots h.w.

(b.) greatly increatied brilliancy of col, "1p.s. cosp. in $q$, leading through the Grecian var. Meliberus, stent. to: var. Gordius, sul:ar: brilliant coppere with munerous blli, spot. 3 with, of withon metallic prep. suttusion; :3:3-37mun.

Loc. Inmensely more $e$ in this region thatn the type. Inder

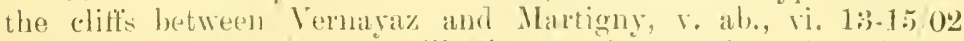
(Bkm.) ; vi. 1501, 02, de., till rii. m.: also on the other side of the Rhone Valley, and on the path up to and beyond la bittiaz. W\%.): Fully, (Granges, sierre (For.) ; l'fynwald, ri. 24 !9 (lilim.): 
in many of the lateral valleys between Martiguy and Brig, ra., Wrolena, nr. Ferpecle Glacier: Niouc and Susillon, in the Val d'Anniviers: Baltschieder (fiar.); St. Nicholas, vii. 1797 ; vi.

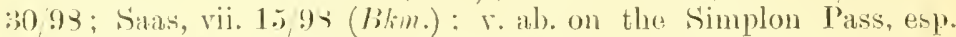
from end to 4th Refuge, vii. /9s (Wh.); Simplon Village, vii. 2 199) (Tutt) ; $c$. in the S. valleys of T'essin, the Talais, and the Grisons.

Grand Salive (liar); not mentionsi, however, ly lil. 1 . his list of captures 11r. Geneva); the lirvent, viii. 18,02: Abriès, viii. m., worn out : Crête de Reychasse up to 7000ft., viii. 111. 1900, worn ; Larche, up to $6500 \mathrm{ft}$. vii. e. 1900); Jiancelonette, viii. 11. 1900 ('́utt): Digne, vi. 499

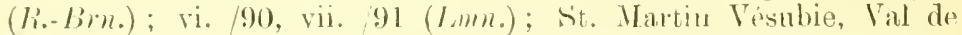
Madone, 7000-7500ft., de. (Rrm.) ; Certosa li Pesio, much scarcer than the type (Noris): Commayeur, vii. l). (1) (Lmm); Pré St. Didier, viii. b. 95 (Tutt); Varzo (Imw); Stresa, vi. 1087 (.Tomes): helow Iselle, vii. $799(\mathrm{Blm}$.$) ; Campiglio, vii. 95$ ( $\mathrm{lmm}$. $)$; Trafor, Meran, Ec. (Thtt); and gen. in S. and S.E. valleys of the Alps.

Directions of Var. (a.) of, fullness and brilliancy of prp. suftusion. (Gen, not v. brt. in the Khone Talley, tho' often brilliant on the Simplon, nr. 2nd Refuge (H\%.); nore so on S. slope, andalso larger (l'ar.); r. brt. prp. at Sitresa (.Jomex); also at Digne (li.-lim.) ; almost confined to costa and thorax at Commayenr (lure) ; poor in col. at Crête de Reychasse (T'utt).

(b.) size of spots; varies greatly, esp. in $q$. Mr. Lowe remarks that at Varzo the markings are all much darker and thicker than in Martigny specimens (this comesponds with Mr. Tutt's experience at Bobbie): in one of Mr. Lowe's specimens, a $q$, the whole h.w. is suttused with hrm., leaving only an or. border with conspicnous blk. spots; this closely resembles a $q$ in the Genera Museum, frou IIyères, marked Alciphron; "a fine blk. \&, Val Malenco, vii. 7, 1900" (li.-lim.).

ab. \& Midas, Lare: has the row of spots ontside the centre up.s. f.w. reduced to dots, the border broad, but opening into a large spot (or spots) at anal ang.; the h.w. baving an ante-margl. hand of blk., more or less wedge-shaped dashes, leaving the whole disc brilliant toppor exe, a blk. disc. spot.

Loc. Martigny, vi. 1900 (Lame); nr. Vermayz, vi. 29, 1900 (Wh.). (other specinems exist, bnt so far as 1 know them, all are from the foot of the cliffs letween Vernayaz and Martigny.

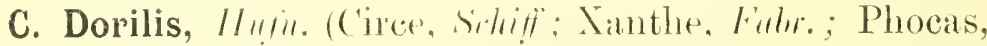

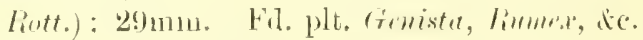

z brin., o with copper on disc f.w. and out. marg. h.w.; (for shape $t$. Al(iphrom).

Dist. Char. 111... h,w. mole or less strongly tiuter with yell. ( 


Loc. In dry sunn youts thonghont swit\% and elsewhele, but

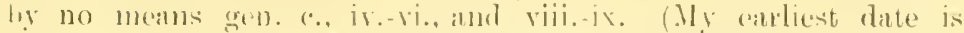
leytaux, iii. 1799 ). In r. early seasons, such as 1s99, there seen to he :3 broods, iii.-Y., vi.-vii., and viii.-ix., lansanme, at (Tutt); Veytaux, not moommon, e... r. 18,01, de. (Ith.): Veyrier, v. 10 :

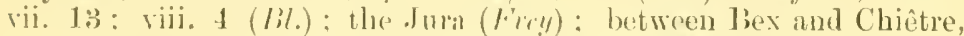

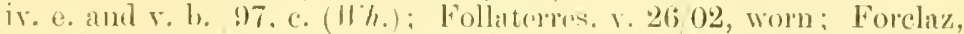

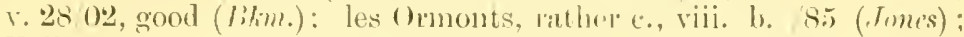
Fully, Sallen, Sion, Sierre, between Y'isp and Stalden, Gondo,

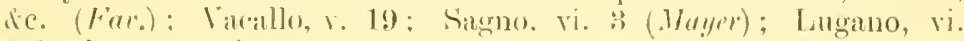

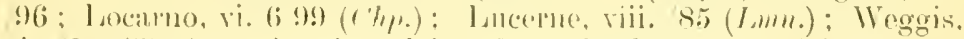
vi. 96 (Jutt): "in the plans from biale to the Grisons and Linguno" (F'riy).

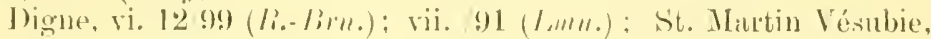

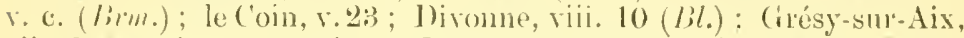
rii. 2.5 96, just emerging: Tourg S. Nanrice, vii. e. 94; Bonrg d'Oisans, viii. 11. 9)( (Thtt) ; Lago Maggiore, ix. 93; Esino, vili. 02 (Mis. Ftu.); ('ertosa di Pesio, ri. and viii. 92 (Norris); Bobbie, viii. 111. 01. fresh; Val d'Aosta, viii. 111.98, v, ab.: Plé St. 1)idier, viii. 1. 98; Torre Pellice, vii. e. ()1 (Tutt); Stresa, ri.b. 87 (Joms) ; Pejo, vii. 9)5: Wolfsberg, vii. 1897 (1،mи.).

Directions of Var. (a.) size: greatly diminishing, culminating in : ab. Nana, $\| \%$. ; a r. small form, $23 \mathrm{~mm}$. and less.

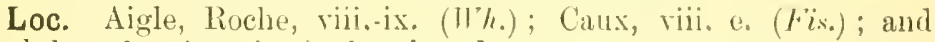
doubtless elsewhere in the late brood.

(b.) increase of size, $111 \mathrm{mber}$, and brightness of ol. spots in ठ 0 , up.s. sometimes extending to f.w.

(c.) appearance of a row of small prp. spots within the or. spots up.s. h.w.

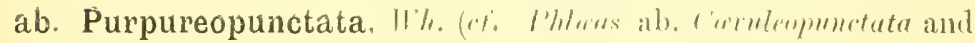
Amphirlamas of).

Loc. leytanx, ․ (01. o (11\%): Les Arants, r. 01. J (Sloper),

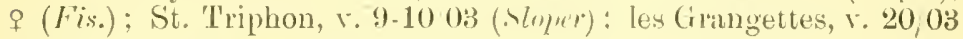
$(11 \%)$.

Digne, iv. e. 97 (Tutt).

(d.) loss of copper col. in $q$ and of or. spots in $\delta$, accompanied by increase of size up to $333 \mathrm{~mm}$.

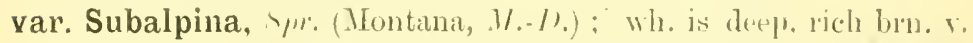
dk. up.s.: \& and \& with slight prepreflections, and without or. spots $11 p$. or 1111 ..

Loc. 'T'he minal mint form, but sometimes as low its $2000 \mathrm{ft}$.

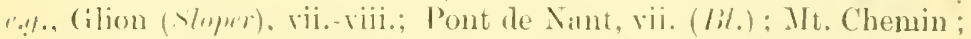

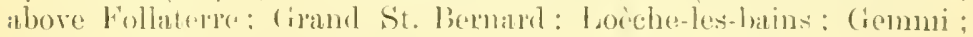

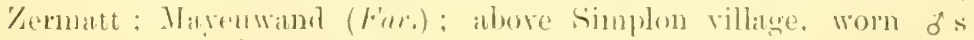

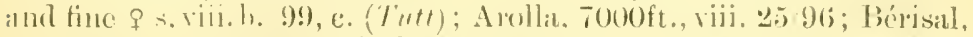

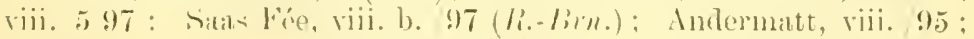

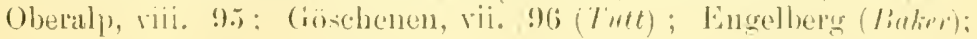


Jaros, vii. 2, $1200\left(l^{\prime \prime \prime t}\right)$; Fusio, vii. 1-12, $1900\left(C^{\prime} / \%\right)$; [pper Engadine, not r. c. ; in wood at foot of Schafberg, vii. (Micholsmin); wide spreat, but genl. scarce on S. alps (l'r'y).

Lal'che, vii. e. 1900 (I'utt); Madone des Fenêtres: Mt. Bahne de la Fréma, (3300ft. (13rm.); abore Certosa di Pesio, vii. m. 92, os r. scarce (Noris); Tal Ferret, above Commayeur, vij.e.94; viii. h. /98 (T'utt); abore Susa; Tal Malenco, vii. 7.1900 (li.-Lin.); Macuguagil (Miss Ftn.) ; 'Trafoi, vii. 111. 1900 (K.-lim.) : lleiligenblut, vii. /97 $((\%))$.

(a.) a modification of the last.

var. (? \& ab.) Brunnea, $11 \%$ : large, no pry. reflections: o with or. spots at anal ang. un.s. l.w., and sonnetimes all along ont.

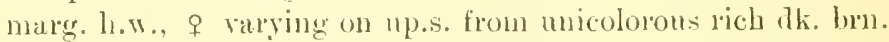
of $\delta$ to dnll copper (ralely) on disc f.w.; h.w. brn. with or. spots of $111 \mathrm{~s}$. l.w. (amd vecasionally of f.w.) reproduced on 11).S.; closely resembles ak. form of llipother $q$ and var. limybia $\&$ on up.s.

Loc. Mïrlen, vii. e. and viii. b. 1900 , c. (IF\%.).

\section{Phlæas, L. : 28mm. Fd. plt. Linmed atertoset.}

o with lk. costa up.s. f.w. and narrower copper band h.w.

Dist. Char. un.s. h.w. Jarkish brn., v. slightly spotted, with faint ante-margl. reddish band.

Loc. Widely distributerl, but not gen. c. in Switz. exc. S. of the Alps: I have only met with it in any numbers in 2 places, ris.. brig, viii. : 195 , on right hank of Rhome abont 500 yols. below the

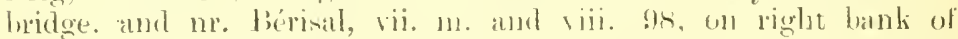
(iantel, above the stone bridge. ()ne naty luet with it singly

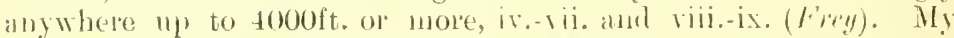
(arliest date is Veytanx, 1st week in Maly 9!). Much commoner

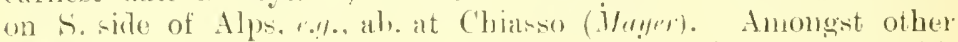
places mentioned are Arrore, vii. 16; Veyrier, viii. 16; ()ires, viii. (lil.): Saas Fee, viii. 1. Sce yt (li.-lim.) : Hisentis, vii. hes

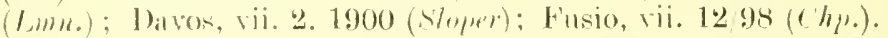

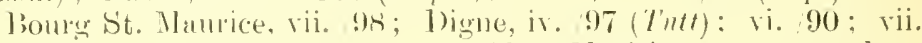

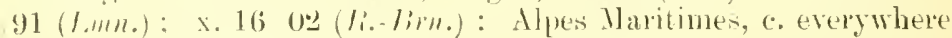

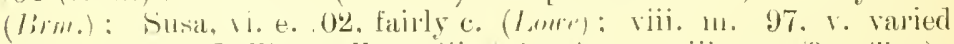
("utl): Torre Pellice valley, viii. 01; Aosta, viii. 11. 98 (T'ma):

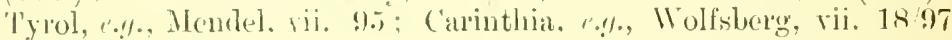
$(1, m m$.$) .$

Directions of Yar. (a.) depth of col. on disc of f.w., and band of $11 . w$. 111... leatling to :

ab. Intermedia, l'utt: grit. col, brussy.

ab. Schmidtii, tritheral: whe col, whitish.

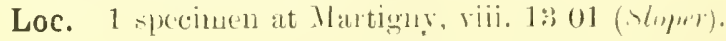

(b.) copper col. sullused with dli.

ab. Suffusa, Lult: culninating in: 


ab. Eleus, Fabr: in wh. the copper is entirely sultused and h.w. distinctly "tailed."

Loc. A v. frequent form of end brool in S., occasionally also N.

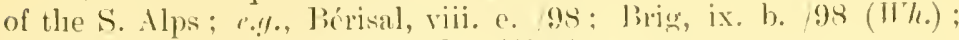
Sion, Sierre, Nionc, Visp, Stalden (I*a*.).

St. Michel-rle-Manrienne, vii. e. 197; Susa, viii. m. 97; Turre Pellice. vii. e. 01 ('T'utt).

(c.) size and number of spots up.s. f.w.

(d.) a series of prp.-bl. spots inside copper band up.s. h.w., forming :

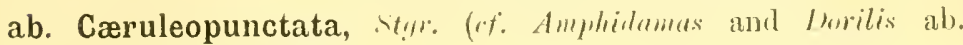

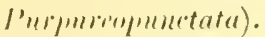

Loc. Esp. in S.; e.\%., at Chiasso half the specinens are of this

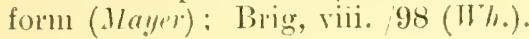

(e.) absence of band up.s. h.w., called:

ab. Obsoleta, T'utt.

(f.) band replaced by long radiating wedgeshaped lines, forming :

ab. Radiata, Twtt.

C. Amphidamas, lixp. (Helle, //h.) ; 266mm. Fil. plt. Pirmerer acetosa, l'olyyomum listurtu.

o with brilliant prp. reflections, o with latge prpe spots up.s. Dist. Char. Brilliancy of the netallic prp.. in connection with small size.

Loc. In Switz. a 1nt11. sp. : II. slope of the Molison in matshy meadows, vi. 25, 01 (lih.) (too early for this loc. in 02); 1 at Yjland-

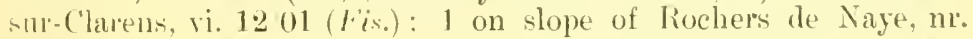
('aux, vii. 11. 01, worn (l,mu.); 1 in Tinilpe Valley, vi. 2502 ('haluriele): 1. worn, at lillars-sur-(iryour, vii. 02 (Moss).

Obs. All these lors are on one chain, and it is therefore probable that Amplidumas may be fomm in suitable, and perhaps less aceessible, matshy spots between these points.

Sitockhorntha] (//\%.): P'as de (heville (Mrissure): 'T'ramelau

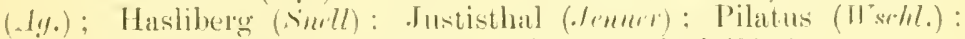

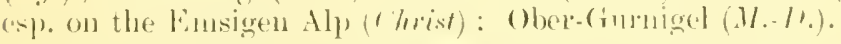

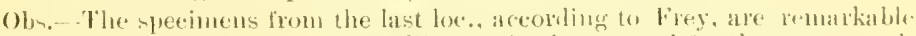
for the extreme billiany of the motallic pro. in the do and for the ante-margl. row of brt. prep. spots on all 4 ws. 5 and \& ; these diservations are certainly true of the Gumgel specimens I have seen at Genevas those from thannelain are, howerer, equally magniticent.

Directions of Yar. (a.) Jirilliancy and (xtent ol prip) suftusion siljuili).

Obs. The suffusion of the Thanclan 8 is of the eol. of A. Lri-. than of the (inmirgel of of the col. of $\mathrm{A}$. 1lia.

Tribe Lrickisl.

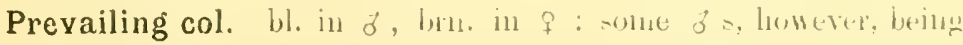
always brit. and thany os sometimes bl. : Has. with ringed eje-spots. 
Genus, Lycæna, Fillr.

L. Arcas, linlt. (Hrebus, Knoch) ; 320nm.. Fd.plt. clover, San!mismlun whicinalis: hyb. l.

V. dk. sooty bru. \& suffused with dk. bl., f micolorons.

Dist. Char. Im.s. with grd. col. dk. mmber brn.

Loc. Execedingly local, and confined to marshy spots: not litherto foum in the Valais. Hermance, vi. 14. 26; Versoix, rii. (Bl.); a field behind the Hotel at Mt. Bany, vii. l). /98, ab. (IIh.): ri. e. 1900 , nealy orer ( $\mathrm{h} / \mathrm{hm}$.$) ; Weesen Marsh, vii. 801$, ab. ; a mile IV. of Attalens, vi. 11 (01; En Samont, above Clarens, vii. $1: 30$, and vi. 1201 (Fis.) ; malshes $11 \%$. Bimschen, at about $3000 \mathrm{ft}$.

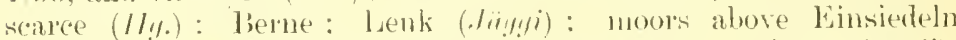

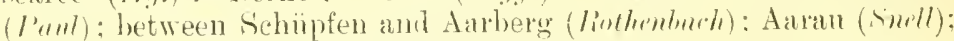
IV. of Poutresina; L. of St. Noritz (Fis.).

Wolfsbercr, vii. 1697 , ab. $(\mathrm{Lmm}$.$) ): (Grand Salive, rii.; Dironne,$ vii. and viii. (!) (Bl.).

Directions of Var. (a.) diminution of size, culminating in :

ab. Minor, lintir.

Loc. Sisclen, ur. lake of Bienne (liatiri).

(b.) distinctness of spots f.w. up.s. $\delta$.

L. Euphemus, IIh. (1)iomedes, lintl.); 32nnm. Fd. plt. Sangmisorba, Lotus comiculatus, clover; hyb. 1. Lightish bl., o spotted, veined, and bordered, of spotted and aimost intirely suffused with blk.

Dist. Char. grit. col. un.s. yellowish brn.; of further distinguisher from Arim o by size, $q$ from Alrom $q$, and Arim var. Hescrea of by the ahsence of all spots un.s. f.w. (and gen. h.w.), ontside the cl. row.

Loc. Marshes and damp meartows: much the sane range in Switz., and often the same loes. as Arows not in the Valais. Tersoix, lii. (lil.); It. Birry, vi. e. gs, ab. (II\%.): sme place and date 1900, worn out (likm.): Weesen marsh, vii. 8.01, v. large,

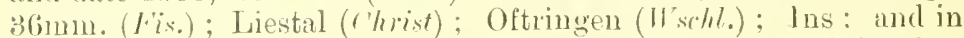
the water neadows mr. Aaran (Sncll); Berne (.Jigng); Schïpfen,

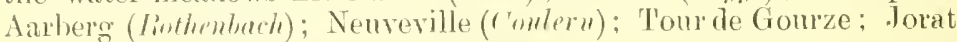

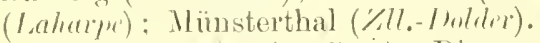

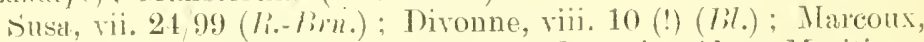
nr. l)igne. vii. (Inmsel); marshy meadows in Alpes Naritimes (lim.): (ertosa di Pesio, ab. in all the wet meatows by the lieinette springs, vii. 13, Ne., 92 (Norris); Wolfsherg, vii. 1897, al.b. $($ l.mm.).

Directions of Var. (a) brightness of $\delta$, depending on extent of dusting with blk. scales.

(h.) extent of blk. suffusion in ?

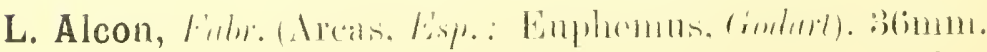

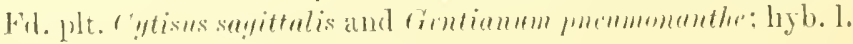




Darkish lilace-bl., o withont. \& with blli. spots and sulfusion 11 p.s.

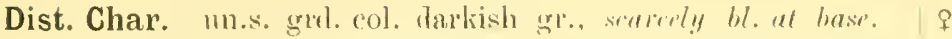
somewhat closely resembles frim var. (Hsima o and yet mole closely the of. but the gred. col. un.s. has a howner tint. and the disc. spots un.s. are smaller and more linear; also ()hsema of is larget.

Loc. l rocal and seldom c., " in openings of woorls in the lowlands, and up to nearly 7000 ft. in the nutns." (lar.) : vi. e.-viii. h. Rossiniepes, rii. 2 and (i, 1900 (lilm.) : Villars-sur-liex, vii. ()2, worn

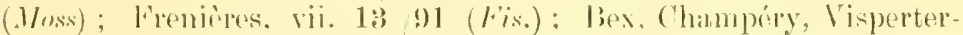

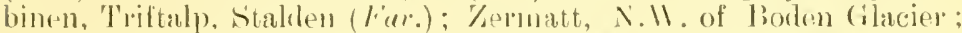
II. of Erolena, beyond the strean, vi. 26 97 (lik.); Riffelalp, vii. 01 (l,mn.) ; Berisal, vii. m. 9s; in the goror leading to the Steinenthal and on the Steinenalp, vii. 1101 , c.: ahove joth Refuge, vii.

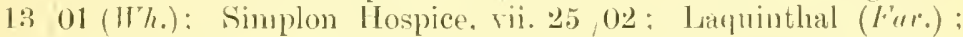

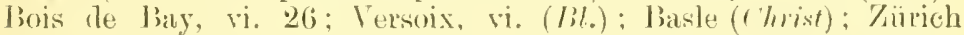

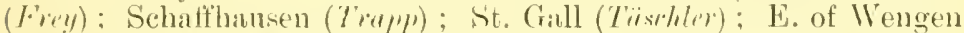
(Fis.) ; " Mry stony places at foot of .Jura," ".!., nr. Olten (II schl.) : St. Blaise (crmlern); Sit. Cergnes, vi. 25 (lil.): lienne and Solenue

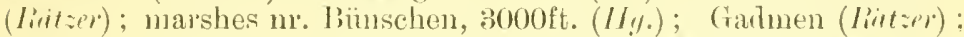
Pergiin, Stulser-weg, e. (//l.); Fusio, vii.b. 99); (illarla, vii. e. 1900, with broad border ( $/$ h. $)$; Morteratsch Glacier, viii. 101 (Fis.) ; Pontresina, vii. 95 (Miss Ftm.).

The Dôle (IRalipr); le Reculet, vi. 26 (Iil.) : Beaurézer: Allos, vi.-vii. (I'orell) ; l)igne, vi. 99 (Miss Ftn.) ; Torre Pellice, viii. b. 01 (Tutt); Macugnaga, vii. 99 ( $(\% \mu$.$) ; (ampiglio, vii. 95;$ Wolfsberg, vii. m. 97 , scarce ( $/, m m$.)

Directions of Yar. (a.) diminution in size:

\section{var. Monticola, styr.}

[Obs. - Stgr., Cat. 1901, p. 90, loes not give Switz. as a loc. for the type, but for this var., which he describes as being rather smaller, lighter gr. un.s., with more hl. at base of h.w.; the difference is not very intelligible, as it is a physical impossilitity for auy specimens to have less bl. at base of h.w. than the siviss mtn. ones, unless they are without a vestige of it. Mr. Rowland-lirown mentions a specimen taken by him at Mattmark, 7,000ft, corresponding with Stgr.'s description.

(b.) diminution of bl. in $q$ culminating in :

ab. I Nigra, $\| \%$. in wh. it disappeal's nnder the blk. sulfusion.

Loc. Stcinentlial, ic.

L. Arion, 1.. : Honmm. Fil. plt. 'Thymm!s strm!llmm (in

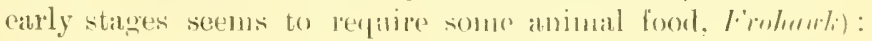
hyb. 1.

Bet. bl. witl slight lilac tiuge: of gent. litroer. and with larger blk. spots 11p... f.w. thatu 3 .

Dist. Char. spots on 11 p.s. f.w, in ennection with linhtish gred. col. $1111, \mathrm{~s}$. 
Loc. Wide spread thronghout the region, but somewhat local, vi.-viii. b. It would lequile a monograph to give all the locs. with their varying forms; the following are only examples, and in most cases neither books nor correspondents give much detail as to size and marlings.] Veytaux, r. 27/97: Caux, vi. 97; Sépey, in many places, large and 1t., vii. b./97 ( $1 \mathrm{~F} /$.) ; on most of the slopes bordering on the Rhone Valley, ".!., all romnd Martigny, Mayens de Sion, Frolena, Val d'Anniviers, Forest of Aletsch, \&c. (Far.); St. Nicholas, vi. 30-vii. 20/98; Binn (Bkm.), \&c. Meyrin, vii. 26; Versoix, viii. 18 (IIl.); Mürren, vii. e. 1900, a lt. form (IF/.); marshes 11\%. Bünschen, 3000ft. (I1\%) ; Liestal (Kane) ; Jura, c.\%,, St. Cergues, viii. 29 (1;.) ; San Stefano, vi. 29, v. dk. (Mayer); Pontresina, vii. \$4, \&c. (Lmm.) ; Val Leventina, v. large and brt. (Till') ; Splugen, vii. 5, 1900, ab. (K.-lin.).

Saroie, e.!., Charoire, vii. e. 02, worn; Megrve, viii.b. 02: The Brévent, riii.m. 02; Grésy-sur-Aix, vii. e. 97 (Tutt) ; Digne, Eaux Chaudes, vii. m., ab.. v. variable, from brt. It. bl. to var. Obscurd (li.-lim.) ; Vallon Obsem, St. Martin Tésulie, Madone des Fenêtres (Brm.) : Lareno, v. large, vii. \&s (Imm.) ; Bremner, vii. 27,1900 , v. di., approacbing (Usema (li.-lirm.): high up the Eggenthal, not r. dls., vi. e. 01 (Lame') S. 'Tyrol, rii. 95 and 97 (Lmm.).

Directions of Var. (a.) size: exceptionally only 32mnu., sometimes 11 p) to 441111 .

(b.) extent of blk. shading orer disc, culninating in:

yar. Obscura, rhrist, in wh. the blk. alnost reaches to the base, esp. in $\delta$.

Ob...-This bar... according to the origmal descripton (Frey, Lepidopteren

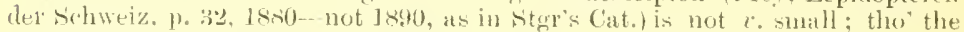
of esp. is gen. maller than the type.

Loc. Gen. in the nutns. Jérisal rii. riil. gr (II\%.); Kermatt.

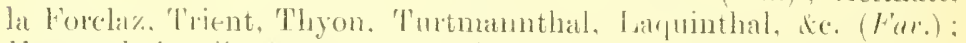

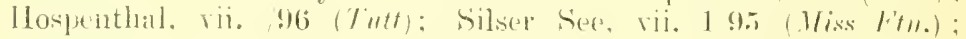
Ftrio, vii. 1.12, 190(), (matda, vii. e. 1!)0( $(1 \% \%)$; Tia Mala,

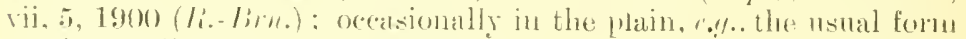
at Sierre, rii. 99 (II\%.): Martigny (F'ar.).

Jigne (li..lim.); Alpes Maritimes above 30ooft. (lim.); Courmayeur, viii. b. 95 (T'utt); Val Ferres, a poor form, vii.b. 01 (laner); Pejo, vii. 9.5; Campiglio, rii. 95 $(1 \%$ \% ; Tillach; San Alp. Kor Alp. rii. $97(1, m m$.$) .$

(c.) size and number of spots 11 p.s.

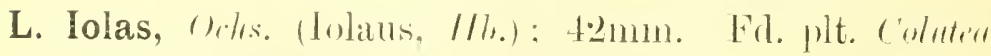
arberesens: byl), p.

o lilac-bl., o blaclish-bru. with bl. suffusion at base.

Dist. Char. large size: 11].8. f.w. mnspotted in both sexes.

Loc. In Switz. confined to the Rhone Valley hetween Martigny and Salpuenen; v. loeal, and confined to spots where the fal. plt. grows: gen. one hrood, vi., but in 1901 there were two. as in $\mathrm{S}$. locs., at its headquater's at Follater'e: r.e. (IFhhl.) and vii. 26, several, quite fresh (IIh.): stme loc. vi. 2:3, 1900, ab.: vi. 2201 , 


1 f only; vi. 21 02, 1 б, yuite fresl (1I\%.); vi. 3,02 , worn

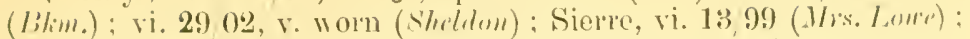
vi. 15, 21, ic. (Wh.); Sion; Corin; Salpuenen (lia.).

Dignes, v. (l'ursll); vi. b. 99. 1 ơ (1/iss l'tu.); vi. 90 (and larvir, vii. 91) (I.mm.): Jotzen (Kame).

Directions of Yar. (ネ.) size: $321 \mathrm{~mm}$. (rarely), to $11 \mathrm{~mm}$.

(b.) size of spots 4 n. .

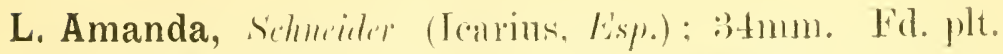
Ficia cracen.

o lavender-tinterl bl., \& hrn.

Dist. Char. J, col.: o bru. fringe, lighter at ont. edge. [The un.s., gr. in $\sigma$, bru. in $q$, may best be kistinguished by the absence of the dist. chars. of other sp. There is no wh. streak as in I'. Ilamml var. Ferrti (the only "blue" wh. resembles the $\delta$ in col.), l'. Almetus var. Rippertii, and $I$ '. Eimmedon: a strongly marked o might be confusen with at slightly marked $I^{\prime}$. Alexis al). Irarimus, but Amama has not the straight row of $t$ basal spots 111 .s. h.w. wh. is found in Mlrix. nor has it the slightest wh. suffusion inside the peacock eyes.

Loc. V. locil : mater the cliffis letween V'ermaya and Martigny, but only in, and close to, the marshes, v. ab. vi. 24, 1900 (I mere): vi. 19, fe. 01, 02 ( $\mathrm{W} \%$.) : ft. of Mt. Ravoire, Martigny ; fields between Martigny and Fully: Vex in the Val d'Hérens (Far.); 'L'arasp, ab. (Killiks); (Hnardia, vii. 1900 (c/lp.).

Annot, vii. $179 ! 9$, a few ; St. Martin Vésubie, vi. 28 to vii. 799 (lam,l); Certosa di Pesio in Val Cravina, vi. b. 92, scarce (Norvis); Monte Viso, Mt. Cenis (Kmm) : Cortina, vii. 17, 1900 (Ki.lim.); Sarnthal and Eggenthal, vi. e. 01 (Ione), (r. infici).

Directions of Yar. (a.) size : from 26-36mm.

(b.) distinctness of peacock eyes mu.s., never $v$ strong, and often absent on f.w. in ð.

(e.) amount of or. up.s. $q$.

(d.) exact tint of grrl. col. 0 .

(e.) extent of ak. suffinsed border up.s. $\delta$; much richer and darker at Hotzen than in the Rhone Valley (Lam).?

(f.) ristinctuess of blk. veining up.s. o; (always v. distinet on h.w.).

(g.) occasional margl, row of blk. spots up.s. h.w. ठ .

(h.) tendency to obsolescence of $\mathrm{cl}$. row of eye-spots, mn.s. f.w. $\delta$.

[Obs. Spuler mentions 3 of from Mölling, in wh. the 2 wows of blk. spots above the or. un.s. h.w. are roalescent, torming large spots.] 
Genus, Cupido, Sichromli.

C. Minima, l'sl. (Alsus, f'alu.) ; 20mm. Fil. plt.

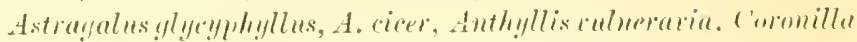
raria, Molilotus, de.; hyb. 1.

V. lk. brn., o with, $q$ without, greenish-bl. scales at base.

Dist. Char. un.s. brownish-gr., with eye-spots f.w. in a nearly straight line, and with the donble eye-spot next hut one to inn. marg. h.w. coming ontwards towards ont. marg.

Loc. Gen. one of the commonest Lycanids; momnts up to about so0oft.; from iv. e. to riii. at lower elevations, vii.-viii. at higher : in the former case probably 2 broods ( $F a c$. . Tutt), rather tlan a prolonged succession of emergences ( $F(n), y)$, as the l. feeds $u p \mathrm{r}$. rapidly. My earliest date is Veytaux, iv. $9 / 99$; extraordinarily ab. in Jura, e.!., St. Georges, vi. e. $/ 02$.

Directions of Yar. (a.) Increase of size (with increase of greenish bl. up.s. $\delta$ ).

var. Montana, Fry: 24-26mm.; eye-spots un.s. often larger.

Loc. Gen. in moterately high locs., $\bullet$. ., Simplon (Far.); but a v. usual form on the slopes above Lavey, ค.!., v.-vi. 02 (Th.).

Le Lautaret, vii. e. $96(T u t t)$.

(1). further increase of size (withont more bl. in $\delta$ ).

yar. Alsoides, (imharl: $26 \mathrm{~mm}$, and above.

Loc. In the high mtns., '.\%. Simplon Pass: Pierre-a-voir sm Saxon; Glacier de Trient (lac.): Lafuintbil (liätser); Mïrren. viij. 2. ice. $(11 \%$. $)$.

(c.) loss of col. in $\delta$.

ab. Pallida, t'utt: up.s. pale gr. (v. rare).

(1.) tendency to obsolescence of eye-spots m1.s., colminating in :

ab. Obsoleta, Tutt: in wh, they hare nealy, or quite, tisappeared.

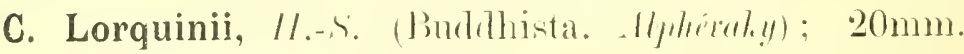
Fil. plt. (and l.) mnkmown.

o reej' pro.bl. (like silums), of hnu.

Dist. Char. un.s. h.w. row of eye-spots in an almost unbroken line, as the last does not conspicnomsly approach the border. o differs also from shrus in size, and broader border; and from Minime in col.

Loc. Al]os Mauritimes (lirm.).

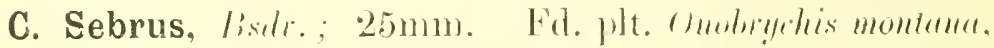

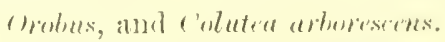

o leep lint. lirp.-bl., \& brn.

Dist. Char. m.s. pale bluish-gr. with spots on f.w. in nearly straight line (c. N. somiargus). 


Loc. Gen. a searce sp., but ab. in many places in Rhone Valley, and fonme up to (j000ft., iv. e., v., and vii.-viii. b. (1st lorood far the more alb.): $\therefore$ ab. on road $\mathrm{mr}$. St. 'Triphon station, $\mathrm{v}$. 15,01, and Martigny, on road to Branson, y. 2001; Lavey, v. 10, fc. 02, c.: Vertanx, iv. 99, and v. 01; Vermayaz, iv. 3002 ; Sierre, vii. m. 99: Martigny, vii. 22 99, a few (Wh.) : riii. 801 (Sloper); Saillon r. al).; Sion; Sierre to Brigg: Bérisal ; Simplon; Laquinthal; Zermatt, ic. (F'ar.); Schatthausen (Trapl) ; in many places round Geneva, hoth in Sivit\%. and Savoie; ' $\%$. (ieneva, iv. 22; Veyrier, v. 13, 22 ; Hermance, r. 29; le ('oin, v. 2:3; vi. 14; Mometier, v. 25, 29 ; vi. 2,5 ; Bossey, vii. 25 (I3l.); (the last 3 in Savoie).

Charoire, vii. e. 02 ('lutt), not uncommon in the Basses Alpes; Grenoble, v. b. 97 ; Digne, iv. 97 (T'utt) ; vi. b. 99 (li.-lirm.) ; esp. le Bois in liocher Coupé, ab. (Iones); Col de Ronaine, about $3800 \mathrm{ft}$., vii. 9, scarce and rather worn (I'omell); Ozglosse, Pain de Sucre, dc. (Kane); above Barcelonette, vii. 3/92 (Norris); Piedmont (Kane).

Directions of Var. (a.) occasional bl. suffusion at base of ws. up.s. + .

Loc. e.g., St. Triphon (Fis.): Lavey, v. slight (Wh.); v. strongly marked specimens from the Jura $(A \% \cdot)$.

[Obs.-The Jura "blues" have a marked tendeney towards bl, in the o s.]

(b.) occasional lt. col. up.s. of. LA r. pale one in Col. Agassiz's collection.]

\section{Genus, Nomiades, $1 / 6$.}

N. Semiargus, liott. (Acis, Shliff.: Argiolus, lisp.); $30 \mathrm{~mm}$. Fd. plt. Welilotes afficinulis, Anthyllis rulneraria, Armeria rulyaris, de.: hyb. p.

o dk. pre., $q$ lorn.

Dist. Char. un.s. hrownish gre, with eye-spots of f.w. in a urury line.

Loc. I)istributed over the whole region; gren. bint not always, c.. sometimes the most ab. of all the Lycanids; v. vi. rii. in the lowlunds and lower slopes; vii.-viii. in mtns. : fomm up to $7500 \mathrm{ft}$.

Directions of Var. (a.) decrease in size. gers. in proportion to altitule, culminating in :

var. Montana, Frey: 25. $27 m m$, with darker grt. enl.

Loc. The highest limits of the sp., e.f. lihmenthat, above Mïrren, vii. e. and viii, l, 1900) top of simplon Pass, viii. m. 97

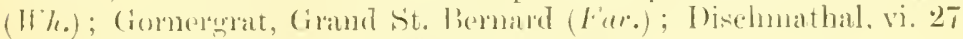

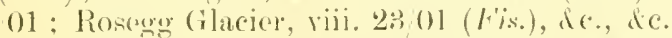

Le Iantaret, vii. e. on: Val Vóni, viii. 98 (l'utt); Kor Alp, vii.

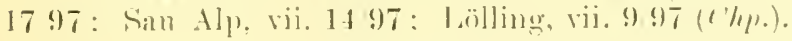

$$
\text { (b.) size of spots mm.s. }
$$

ab. Etnæa, $\% l l .:$ in wh. they are large and smmoumled with wh.

ab. Cæca, F'uch:s: in wh. they ire obsolete.

ab. Striata, Wh.: in wh. some are extended into streaks.

Oh:. I have seen nu \& of this ab. 
(c.) occasional slight bl. suttusion at base of ws. ㅇ.

(1.) reepening of grt. col. in $\delta$.

Loc. r.!., abore les Arants, viii. 296 (li.-lin.); Pisbinno, vi. 12 (Mayer).

N. Cyllarus, liott. (Damotas. IIl.); 30mm. Fel. plt. Astrayulus, Trifolium, Melilotus, (motrychis, rimista: hyb. l. б brilliant bl., \& brn. with brt. bl. bases.

Dist. Char. un.s. f.w. eye-spots increasing greatly in size from costa to below the middle, in connection with bl. or grm. suffin. sion over greatel part of h.w. (r. Melanops).

Loc. C. in most years from Montreux to Mörel, esp. at Lavey (Wh.) ; Sion and Prig (Far.); iv. e. v.-vi. (My earliest date is Veytaux, ir. 5.99.) Not gen. found above $3000 \mathrm{ft}$, but mounting exceptionally consilerably higher, when it may be found later; $\bullet . ! .$, Splugen, $4700 \mathrm{ft}$., rii. 5, 1900 (li.-Pm.). In many places round Geneva; Veyrier, ('hêne, Jiois de la Patie, Pois de Pay, de., v. 6-27 (1,l.). Not V. c. elsewhere in Switz.; Locarno, vi. b. 02 (1 / $/ \%$ ); San Stefano, v. 22 (May/r); Weissenburg, vi. h., not c. (H!) : Jura (christ); liergell (t'mey); Tarasp (Thrist).

Grenoble, v. 97, v. large; ]ligne, iv. e. 97 (Tutt); vi. 90

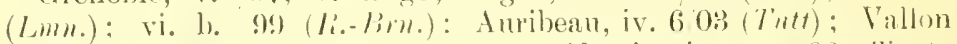
Obscur, St. Martin Vésubie (lirm.); Alassio, iv. m. 0:3 ('utt): Certosa di Pesio, ri. b. 92, c. (Nomis); Aosta, v. 95, e. fine (Miss F'm.); Orta, v. m.-vi. m. 1900, scarce (Lure); Trafoi (Frenl).

Directions of Yar. (a.) Size: reaching to $33 \mathrm{~mm}$. or $34 \mathrm{~mm}$., but sometimes v. small, culminating in :

ab. Blachieri, Milliwe: sometimes as small as 22mm.: $11 n . s$. eye-spots gen. large (lut r. infiv.).

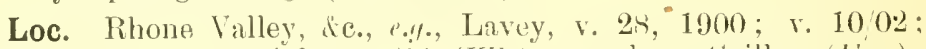
Veytanx, v. 01 ; Aigle, v. 01 (Wh.); c. above Saillon (I'ur.); 'Troinex, iv. 29 (lil.).

Monnetier, vi. 3, 4 (lil.) ; St. Martin Vésubie, vr. 692 (Irm.); Susa, vi. $18,02($ louee).

(b.) number and size of spots $111 . \mathrm{s}$.

ab. Tristis, Grhard; with eye-spots f.w. v. large.

ab. Lugens, ('ararlja; almost (sometimes quite) withont eye-spots h.w. np.s. o darker in tint, o v. Ak. (ft. ab. Andremgii, infivil).

ab. Dymus, liklih. : without spots ın.s. f.w.

ab. Subtus-radiata, $(h, t h$. : spots of $1 \mathrm{~m} . \mathrm{s}$. f.w. anil sometimes of b.w. prolongurl into strealis.

Loc. Charpigny, v.9, 1301 (lik.); a magnificent of with streaks on all 4 ws. Branson, v. 1502 (11\%.).

Obs. - With regard to the var. in number of spots in the hand of f.w. un.s., I cimnot do better than refer to Mr. Iowe's captures at susia and Certusa di Jesio, 6 spots being the normal number: 1 o, an ab. lilurhieri, with 2 , and

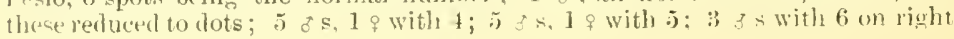




and 5 on left w.: 485,2 is with 7 ; ome of the $5 \mathrm{~s}$ with 7 ipots has also "a small but distinct basal spot on ench f.w." (lint. Ree., xis., 3333). I hicve also a 8 with these basal spots, which has ${ } i-p$ ts on the right wing and 7 on the left-the reverse of $\mathrm{Mr}$. L Inwe's.

(c.) diminution of bl. in $q$ m.s., culminating in :

ab. \& Andereggii, Rirhl: almost, often quite, withont lol. : large spots min.s. esp. on h.w.

Loc. So far only in the Valais and the neighbouring parts of Taml. Veytamx, ir.e. 97: Lavey, r. 2401 ; r. 1002: Sierre, v. 702 ; Sion, v. 2202 (1/\%.) ; Martigny, Pranson, Saillon (Fir.)

(d) col. of un.s. h.w., varying from deep sky-bl. to lt. enemali ginll.

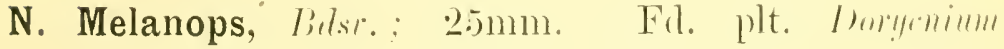
decumbens.

б brt. bl., \& blackish-bru. with bl. suftusion.

Dist. Char. row of spots un.s. f.w. greatly increasing in size from costa to below the midhle, h.w. scarcely sprinkled with bl. at base; further distinguished from ryllams ab. Iilurliniri by a faint margl. row of lumules un.s. h.w.

Loc. A correspondence with Mr. Elwes has elicited the fact that it was undoubtedly this sp. and not f'yllarms al). Iilachieri that he took $n$ r. Sion in the 2ur week in May, 87 . These are the only Swiss specimens known, though the sp. has frequently been looked for since in the same loc.: being small and r. local, the exact spot may have escaped detection, or the insects may have been pasised over as small ('yllams, wh, is ab. nl' Sion.

Digne, iv. 502, c. (IR.-lim.); ah., esp). in the Bois du Rocher Compé, r. b. 9\& (.Jum's); ir. e. 97, perbaps the most ab. "blue" (Tutt). Vallon Obsemr, ile. (lim.): Cannes, ir. ss (Tutt): on thyme, up to about 2500ft. (l'merll).

Directions of Yar. (a.) extent of bl. mp.s. ?.

(b.) diminution of spots 11 .s., those on h.w. being sometimes not ocellater.

Obs.-This is not ab. Marchandii, lisell.. as apparently supposed by lirm.. this ab. being without spots un.s. fir., and heing so far confined to Catalonia.

Genus, Polyommatus, L.trl.

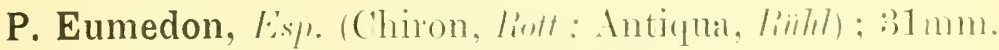
Fid. plt. seeds of Grotnimm sammimmm and ri. prutenses. Brt. Ali. brn. o withont, o gen. with or. spots at anal ange. up.s. h.w.

Dist. Char. un.s. h.w. a wh. streak extending from disc. spot almost to ont. marg., more or less werge-shaped. the guint wi the "rody. bein!! turatids the mar!!

Loc. Not gen. c., but mounting up to Goooft..or more, ri.-rii.; 
Veytanx, vi., Sépey, vii. 797 (Wh.) ; Val d’Amiviers, vii. b. /97; Sierre, vi. 17-2t 93 (li.-lim.); Arollil, c. vii. 12, 1900; St. Nicholas, vi. $30 / 96$; vii. 11 98, \&c. (Bkm.); Saas, vi. m., Mattmark See, vii. e. (.Iones); Berisal, vii. 98 , v. ah. (I/\%.); and gren. in the valleys of $S$. Talais. The Engadine. $\because \% \cdot$, Pontresina, vii. $/ 95$ (Miss Ftn.): ft. of the Schafberg, vii.c. (Joms), \&c. Dischmathal, vi. 2701 (Jis.) : Fusio, vii. 99: Guarda, vii. 29)-81, 1900 (( /\%.); Bremgartner woods, mr. Berne (Fry); Weissenburg, scarce (Hy.):

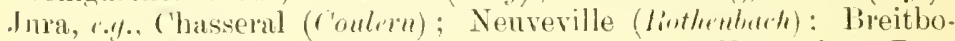
denalp, nr. Meiringen: Kandersteg (M..ll.); Ja Vare, ahove Pont de Nant, vii. (Iil.).

Pontalier (Kame); Le Lantaret, vii. e. 96; Abries. viii. 111. 1900 ('Tutt): liasses Alpes (Kam): Alpes Maritimes on all mtns. (Milliere): Cogne, viii. 7-12,94; Courmayeur, vii. e. It ('Tutt); Macugnaga, vii. 99 (C/\%) ; Susa, vi. 2799 , v. c.; Cortina, vii. 27 , worn (L.-Lim.); Campiglio, vii. 95 (Limn.): Stelvio. vii. 12. 1900 (F.-Bim.): Val Bigontina, viii. 95 (Tutl.

Directions of Yar. (a.) liminution in size of eve-spots $1 \mathrm{~m} . \mathrm{s}$, culminating in

ab. Subtus-impunctata, $l u x$; in which they are absent from f.w. ab. Speyeri, Hus: : in which they are al together absent.

(b.) absence of or. up.s. h.w. $q$.

(c.) tendency to obsolescence of wh. streak, un.s. h.w., culıninating in :

ab. Fylgia, Syumellet!l: in which it is obsolete.

[Obs.-This is a var, of the extreme N., bnt Stgr. says also "ab. ubique"; it can only be expected in the highest altitudes reached by the sp. Mr. Buckmaster, however, notes a from sierre- another instance of the curious tendeney of that locality to produce $m$ tr. forms, Cj. Arion vir. Obscurce.]

P. Donzelii, Bsede.; $26 \mathrm{~mm}$. Fd. plt. (and l.) unknown.

子 lt. steely bl. broadly dk. bordered, + bru.

Dist. Char. un.s. h.w. a wh. streak from the indistinct peacock eyes to the disc. spot, more or less werlge-shaped, the point of the wedye beimy towarls the base.

Loc. In Switz. only in the Valais and the Engarine, between $4000 \mathrm{ft}$. and 6500ft. (exc. Martigny-Combe, de Romgemont), vii.-viii. Ponchette, in Val d'Anniviers: damp places by the Virge below the Riffel ( $F a v$ ) ; by chapel of St. Lament between Vissoye and Zinal, viii. $1 / 97$, c. (li.-Brn.); Turtmannthal, viii. 18/91; Lötschenthal, viii. $9 / 90$ (Fis.); Saas Fée, vii. e. $/ 85$ (.Iones); a pine forest in the Saas Valley, ab. (F'ar.) ; Rérisal, viii. /97, /98, scarce; Simplon Village, viij. h. 99 , c., vii. 10/01, ab. ( $1 \%$.$) ; Pontresina, vii./95 (Miss$ Ftn.); at fi. of Schafberg; Rosegg Valley, vii. (Nirholsm); Sils Maria; St. Noritz; Celerina: Sammien (Fry): (ampfer. scarce (Jones).

Allos; Barcelonette, vii. (Porrll) : (tlaisolas; Golessart: Digne; Mt. Cenis (Kum'); Valley of the Borcon (Rim.); Commayeur, moraine of Glacier de Mliage, viii. b. /98 (T'utt); Cortina, vii. 21, 1900 ; Trafoi, vii. 12, 1900 (H.Lin.). 


Directions of Yar. (a.) amount and distinctness of or. spots un.s. (b.) \&, amount of bl. at base of h.w. up.s. (always slight).

P. Damon, Silliti. (Biton, Sulsur) : 35mm. Fl. plt. Onobrychis sutira: hyb. 1.

of brt. slightly greenish.bl., with hosed dk, suffised lorder: q smaller, bi'n.

Dist. Char. un.s. h.w. a long whitish streak, not wedge-shaped. reaching almost from base to nr. out. marg.

Loc. Not c. in N. Switz. Schaffhansen (Tram) ; St. Gall (Tüschler); Zürich (Frey); Liestal (Christ); Arlesheim (hnecht); nr. Lucerne, viii. e. 99 (Sandford) ; Weggis, vii. 96 ; Rigi. vii./96 (Tutt); gen. distributed, often c., and sometimes ab. in E. Vaud, the Valais, the Bernese Oberland and the Grisons; e.y., les Avants, vii. 30 01 (Sloper) ; Aigle to Sépey, vii. /97, and other years, v. ab. (II\%); viii. 298 (Jomes); throughout the Rhone Valley, c. (Wh.); Evolena, Inden, Loèche-les-bains, Visp valley $n p$ to St. Nicholas, sc. (Fur.) ; below Bérisal, v. c., viii. 20/97, and earlier other year's (II h.); Weissenburg, c. (H\%.); (irindelwald and Mirren, vii. /89 (Lmm.); c. nr. St. Moritz, vii. (Nicholson); Guarda, vii. 1900; Pontresina, vii. 1900 ( ( $/ \mathrm{h} \%$.) ; Bad Alvenen, vii. $/ 88$ ( $\mathrm{Lmn}$.), \&c.; nt. Geneva, Veyrier, vii. 13; Sierne, vii., Monnetier (Saroie), vii. (IBl.): not uncommon on the Jurn Vaudois (Wh.).

Gen. c. in Saroie, Hautes Alpes, and Basses Alpes, e.\%., la Clusaz, viii. 4/02, v. ab.; Abriès, viii. m. 1900 , v. ab. ('T'utt); Digne, vii. $/ 91$ (Lmm.) ; Bourg d'Oisans, vii. m. /96; Jionrg d'Am, viii. m. /96; Bourg S. Manrice, vii. e./98; Petit St. Bernard, viii. 1./98; Barcelonette, viii.m. 1900 ('T'utt); Barcelonette and Allos, vi. e. /92. ab. (Norris); local in Alpes Maritimes. top of Balme de la Fréma, $7300 \mathrm{ft} .(\mathrm{Br} m$.$) ; Cannes (l.mn.) ; Certosa di Pesio, ab. on damp spots$ under Cima Carr, and in Val S'sestrera, vii, viii./92; Commuluenr, viii. m. $/ 99$; Pré St. Didler, viii. m. 9s; above Bobbie, viii. m. $/ 01(T u t t)$.

Directions of Yar. (a.) diminution of size, culminating in:

var. Ferreti, Far: : $25 \mathrm{~mm} .29 \mathrm{~mm}$. ; grd. col. of of it much more lavender tint, with dk. suffusion sonetimes greatly mularged. esp. in Val Ferret; un.s. $\delta$ and $f$ rather less dk., wh. streak often more sharply defined.

Loc. Ab. in the Val Ferret (or Ferrex), esp. at the (inturl lerret (Fac.); upper end of Lanterhrunen valley, viii. 1, 1900: Vallorbe, viii. b. $/ 02$ (II\%) ; Camper (.Jones); Sierre, vii. 6 , 86 , aberration. (bl.).

Le Lantaret, vii. e. /96 ; Larche, vii. e. 1900; Cogne, viii. 7-12, /94; Au Prat, viii. 1n. /01 ('T'utt).

[Obs.--This var. was wrong]y described in Favre's " Lépidoptères du Villa is" as var. Actis, $H_{.-S}$., an error which is corrected in the "Supplement" of 1!403.]

(b.) tendency to obsolescence of spots. always small, un.s. h.w. 
P. (Almetus. Lisp.) var. Rippertii, listi: : :6mm. Frt. plt. (and l.) unknown.

Dk. brn., o with, $q$ without nerrures of basal half and dise. cell up.s. thickly furrer.

Dist. Char. Imn.s. cleal yell.-brn., with wh. streak on h.w.; further

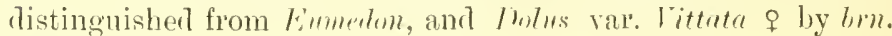
ininge.

- Loc. V. c. on lavender blossom in some localities round Digne, vii. 99 (Miss J'tu.), e.\%, half-way up the (onssons, 3500ft., vii. 5 ani 6 (R.-lim.); La Bollène, vi. 24.92, on laventer, worn (lirm.): S. 'Tyrol (Kunc).

Directions of Yar. (a.) sometimes trace of wh. streak un.s. f.w.

*P. Dolus, //h. : 35mm. F(l. plt. sanfoin. o $\mathrm{v}$, pale bl. (paler than rorydun), \& brin.

Dist. Char. б, grt. col., and brn. furring on basal half up.s. f.w.; \&, concave outline of h.w. just before anal ang., distinguished from dilmetus, wh. is the same shape, by smaller size and lt. fringe.

Loc. The Basses Alpes, not occurring higher than about 1600ft. (I'turell).

Directions of Var. (a.) occasional presence of an ill-defined wh. streak, un,s. h.w.

ab. Yittata, (1)th.: (doubtful whether it occurs ontside the Department of Lozère, wh. is not in the region.)

P. Meleager, Esp. (Taphnis, lir/str.); $35 \mathrm{mmm}$. Fil. plt.

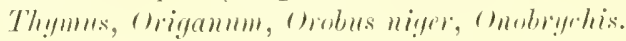

V. brt. lt. sky-bl., o with narrow, of with broad blk. border; of has also the nervures broarly sutfinsed with blk.

Dist. Char. l.w. a noteh nr. anal ang. forming 2 rndimentary "tails," more marked in o.

Loc. lixtrenely local in Switz, only in the Valais between Martigny and Visp, and at Tarasp, vi. e.-viii. m.; Pfynwall, principally nr. Pfyn, vii. 14 and 1999 , good; viii. 1499 , o s r. worm, os good; vii. 1301 rather worn (11\%.); vii. 19-20, 1900, fresh (I lim.) ; Sierre, vi. e. (Jiigri) ; riii. 1699,1 o slightly worn (II\%): Martigny at the Tour de la bittiaz and the surrounding vineyards, vi. 2892 , and above Plan Córisier, vii. 502; Val d'Anniviers: from Sierre to Loiche by Salquenen and Varen; Visp, Stalden, and IIuteggen (Far.); Tarasp, nr. the Knrbans (hillias). lts best loc. in the Valais is nudoubterlly the Pfynwalr, and in most years the likeliest time the 2 nd and 3 r.d weeks in July.

St. Michel-de-Manrienne, vii.e. 97 ('T'utt); Jeanr'zer, vii. (I'mrll); Digne, ri. 13 99, just emerging (li.-limo): rii. 11-16 s9, r. c. (Mrs. Nirholl); St. Martin Vésubie; Vallon Obscur, \&c. (lirm.); Castellane (Porrell); Certosa di Pesio, vii.-viii./92, not. c. (Norris); 


above Bobbic, viii. m. /01, worn ('lutt); Susa, vi. 27 99 (li.-lim.): viii. m. 96, wom ('lutt) : Pré St. Didier to Aosta, viii. b. 98, worn ('utt) ; Botzen, vii. 14 02, not fresh (l.owe); various places round Vienna, vii.-riii. (Miss litu.).

Directions of Var. (a.) $q$, almost complete loss of bl., forming: ab. o Steeveni, 'revitshlie';

Loc. The usual form in the Valais: (2 type os at Martigny, 11 sish.

Alpes Maritimes, commoner than type (lim.); I)igne, vii. 290 ,

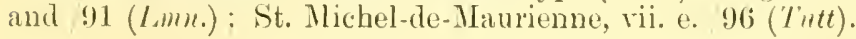

P. Corydon, l'mlu (Tiphys, lisp.); :3tmm. Fid. plt. Comilla, licia, Astrayalus, \&c. : byb. 1.

o pale silvery bl. with greenish tinge, o dk. fawn-brn.

Dist. Char. Col. (un.s. f.w. gen. has principal line of eye-spots so bent inwards below the micllle as to form a line with disc. spot.)

Loc. I: gen. and widely distributed, sometimes in amazing abundance ( $\because \%$, between Mïren and (imelwald, viii. i. 1900); monnts up to $7500 \mathrm{ft}$. or more; one brood only vi. (in s.), rii., riii., and often ix.

Directions of Yar. (a.) size: from $26 \mathrm{~mm}$. to $38 \mathrm{~mm}$.

(b.) tint of gred. col.

ab. Calydonius, lmee: almost the bl. of Meleuger : up.s. f.w. with marrow, r. blk. and r. clearly defined border: h.w. margl. row of strongly marked and isolated blk. spots: mn.s. f.w. blk. spots r. large, on much darker gr' grd. col. than type: h.w. with much bl. at base, or, eye-spots rather small and pale, gret. col. rather dingy, without a trace of fawn-col.

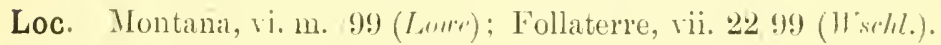

(?) ab. Hispana, II.-S.: lighter, pale spotted marg.; a transitional form is not uncommon in Swit\%.

ab. \& Semibrunnea, Milliar (Semi-syngraphla, 'Intt); base bl. to disc. spot f.w. and beyond in h.w.

Loc. Not c., Périsal, viii. 97 ( $17 \%$.).

Alpes Maritimes (lim.); Lago di Loppio and Riva (.mmes).

ab. \& Syngrapha, herestein (Mariscolore, (imhord); bl. to the or. bor'cler.

Loc. The hottest parts of the rerrion; r. scarce in Sivit\%; 1 at branson (Far.); Tramelan, 2 superb examples ( $1 \%$.).

(c.) extent and distinctness of or. spots up.s.

ab. Aurantia, Tiut: $q$ with distinct margl. or. spots edged internally with paler.

Obs.-One cannot, I think. be wrong in including here the of form in which the spots up.s. h.w, are edged interiorly with or, ; this cecurs not 
infrequently in Switz. At Lisino above Varenna about 20 per cent. are of this form (Miss Ftn.).]

(1.) size of spots and breadth of border up.s.

[Obs.-The forms named in 'Tutt's "British Butterflies," pp. 166, 167, only partially apply here. So far as my experience goes, the broad marg. f.w. and v. distinct and rather large spots h.w. always occur together; and, similarly. the narrow border f.w. gen. goes with smaller spots h.w.]

"In the Basses Alpes the blk. of the border has practically disappeared. leaving in some specimens only faint gr. ocellations, e.g., Digne, vi. /99." (R.-Brn., in titt.). This form I take to be :

ab. Punctata, 'T'ltt.

(њ.) tendency to lighter grd. col. un..., culninating in :

ab. Pallida, Tutt: " $\delta$ wh., \& pale ochreous."

(f.) tendency to obsolescence of spots un.s.

ab. Obsoleta, Trut: in wh. the tendency is marked. [I took a $\delta$ at Vallorbe, viii. 1002 , with right h.w. only of this form :both f.ws. are ibl. Striata.

ab. Cinnus, $H b$. : spots on h.w. not ocellaterl.

(g.) tendency of spots un.s. to coalesce.

ab. Striata, 'lutt : in wh. they are more or less joined into strealis.

ab. Arcuata, I'ymer : in wh. the lowest basal spot f.w. is joined to the lowest of the cl. row by an arched streak.

P. Bellargus, liott. (Adonis, //6.) ; $32 \mathrm{~mm}$. Fd. plt. Genista, coronilla, Tritulinm, Hipunorpis commsa: hyb. 1.

o brilliant sky-bl., 9 bru.

Dist. Char. col.. in comnection with distinctly chequered fringe. o distingushed from f'mydun of by its much darker gr. col. and fringe-narkings. In Switz, at any rate, it is really inpxcusable to confuse thent. Hylas has wh. fringes.

Loc. Gen. distributed and often (.., esp. in the lowlands and lower slopes, clearings of wools. Re., v.-vii. and viii.-is., but mounting as high as $5000 \mathrm{ft}$. or even $6000 \mathrm{ft}$, e.., ab. at Bérisal, viii. 97 ( $\mathrm{H} \%$.) : Zernuatt $(\mathrm{Far}$.$) . Finest in S. locs.$

Directions of Yar. (a.) tint of grr. col. in $\delta$. Of the two usual shades it is suggested ('Intt, British Butterflies, p. 170) that the type name should be reserved for the more lilac, and the nane

var. Adonis, $/ t b$, be applied to the more brilliant and greener form: 2 other slimles are occusionally found:

ab. Pallida, T'utt: paler, nearer in col. to Alris, and

ab. Suffusa, l'ntl: of a darker, more leaden bl.

(b.) anount of bl. up... ?, culminating in:

ab. ? Ceronus, lisp, wh. has bl. like the o extending to the or. boriler.

Loc. The intermedate forms are often c., the extreme form is 


scarce in Switz. Montana, vi./98 (hore) ; Sierre, viii. e./99 (IIh.); Jura, superb specincus (A!)); Jasle (Kmerhl); Liestal (Christ): banks of the Sarine nr. Gruyère, viii. $29 / 97$, the predominant form (R.-Bru.), ife.

Savoie, e.y., Monnetier, vi. 5 (Ihl.): Basses Alpes, Digne, c. (.Tones); vi. $/ 90$ (Lmm.); Alpes Mariuines (Iim.) ; St. Martiu Vésubie, vii. 4/02 (lientull); Orta, v.-ri. 1900 (Lome). Gen. commoner on S. than N. Alps.

Obs.-There is no ground for applying this name to ab. \& Plunctu, the 2 forns often occur in different locs., the other sex being typical.]

(c.) tendency to obsolescence of spots un.s. Forms exist with one or both basal spots f.w. missing, parallel to Alexis abs. Iphis and l'arimus.

ab. Cinnides, Styr.: spots on un.s. h.w. without ocellation.

Loc. V. scarce: Martigny, Sierre, Zermatt (Far.) Alpes Maritimes (lim.) ; Yrvoire, vi. : (Bl.).

ab. Obsoleta, Tutt; in wh. many of the spots are olsolete.

[*(?) ab. Krodeli, crillmer: in wh. all but the discoidals are absent.

(d.) đ with row of 1uargl. blk. spots up.s. f.w.

ab. Puncta, Tint: in wh, they are small, but conspicuous.

Loc. Warm places; $r \%$, Follatere (II\%); Orta (Lurr), ile.

ab. Punctifera, (Wth.: with large spots, broader blk. marg., gru. tint in bl. up.s., brighter un.s.

CObs.-This form, if it ocenrs at all in the region, can only be looked for on the hottest S. slopes.]

ab. Striata, Tiutt.

(e.) tendency of spots $111 . \mathrm{s}$. to conlesce.

P. Hylas, Ksp. (1)orylas, Hb. : Argester, Brgstr.) : $32 \mathrm{~mm}$.

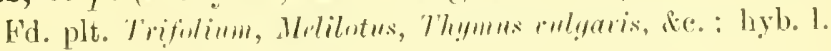

o hrilliant sky-lil., \& bru.

Dist. Char. un.s. brvadly suftused wh. borter, esp. f.w.; fringe wh.

Loc. Gen. distributed on limestone, and often locally ab., v.-vi. and vii.-viii. at lower elevations, vii.-vii. at higher. Pasle, scarce (Christ); Ziurich (Fry); St. Gall (Tïschler); gen. distributed on the Jura (r. infiri); Mit. Barry, vi. 29; Rossinières, vii. 2, 1900 (Bkm.); Weissenburg, not uncommon, 2 broods (H!l.) ; Hermance, vi. 1.; Veyrier, vi. 17, and vii. 30; and other places romnd Genera (lil.); gen. distributed in and romnd the Rbone valley: Teytanx: Sépey; mder the clifís between Vernayaz and Martigny, e.t., vi. 1: $/ 02$; below Bérisal, esp. at the Ganter bridge, viii. (11\%.); Simplon, vii. e. 99 ; Guadra, vii. 1900; Fusio, vii. 1900 (cllp.) : Haudires. Evolena, Arolla, viii. m. 99 (Twtt); vii. 15, 1900 (likm.) ; Kinal, vii. 31 78, r. ab. (li.-lim.) ; Kermatt, small specimens ( H rey); ic., Lingelberg (lialier); Neulausen, Interlaken (Lm. ) nt. Thusis, vii. j, $1900\left(L_{i} .-l_{i} / n_{0}\right)$; gen. in S. valleys.

Grésy-sur-Aix, viii. m. 1900 ('Tntt); Chamonix, viii. 93 (Miss litn.) ; Digne, iv. e. 97 (Intt); vi. 90, vii. 91 (Lmu.); Villon 
(M)seur ; St. Martin Vésubie, not r.e. (lirm.): Abriès, viii. m. 1900; Courmayent, vii. e. 94; viii. 17 9s; Pré St. Didier, viii. b. 98; Sinsa, viii. 111. 97; A 1 Pra, viii. ı. 01 ; Torre Pellice, viii. b.; l'oblie, riii. w. 01 (lutt); Susa, vi. 25 99, $q$ s r. fine and brilliantly marked (R.-lim.); Lake Como, rii. 95; Olgiate, ix. $9:$ (Mis Ftn.); Stelvio (li.-lin.) ; S. Tyrol, vii. 95; Heiligenblut, vii. 2497 (L.mm.) ; Mötling, viii. 97 (Miss Ftn.) : \&c., \&c.

Directions of Var. (a.) $\delta$, borter of blk. spots up.s. h.w.

ab. Nigropunctata, $\| \%$. : blk. spots more or less conspicuous, blk. marg. sometimes broader.

Loc. Occasiomally with type. The only form at St. Georges, Jura, vi. e. 02 (II\%.).

(b.) tendency to obsolescence of spots un.s., esp. h.w.

(c.) tendency to increase in number of spots un.s.

( :) ab. Addenda, 'lutt: a name given to certain specinens talien at Susa, viii. 11. 96. At the same time and place were taken some r. small specinens, wh. were namet:

ab. Minor, Tutt: a Swiss specimen taken by Mr. Fison measures only $28 \mathrm{~mm}$.

(1.) number and size of red spots up.s. + .

(e.) occasional coalescence of spots un.s. f.w.

(f.) occasional bl. on $q$ up.s., gen. only a slight powdering at base, but Frey mentions "a magnificent bl. o at Bergin, viii. 76."

ab. \& Metallica, lar. : r. kk. up.s. with a comspicuons powtering of wetallic bl.grn., sometimes on f.w. only, sometimes also on h.w. extending from the base nore or less along the nervures.

Loc. It. Chemin (Hischl.); Salquenen (de limegrement); the Jura (.1!.) ; Chiasso, vi. $2+y+($ Ha!er $)$.

P. Escheri, //\%. (Agestor, Cimlunt): 3Sinm. Fil. plt.

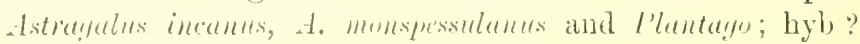
or. or 1 .

o brt. J). (between Alexis and linlurmus), o bru.

Dist. Char. narrom l,1k. ont.-margl. line continued round apex, m.s. f.w. : o further Mistinguisherl by col. ; only Lheretes and N. ryllarms resenble it in this respect: also from Aledis ab. learinus by larger size, and o by or. spots up.s. f.w. being rectangular rather than wedge-shaped : no basal spot un.s. f.w.

Loc. T. scarce N. of the S. Alps except in Lower Talais: one pair che to Ollon (l'anl), vi. 2001 ( $11 \%$.) ; locally ab. in Lower Talais, vi-vii., Martigny, Arbaz sur Sion, Sierre, Pfynald, \&c., to Jirig: Tisp to Kermatt and even higher ( / at.) ; Evolene, viii. 1296 


(li.-lim) : from 2nd Refuge to Jierisal, vii. 7 01, de., r. al. ( $11 \%$.); also on $\rightarrow$. sicle of the Pass (liar.); the (irisons, 1..., Campfer, rii.,

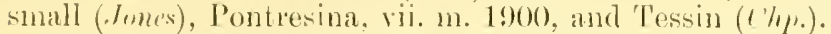

V.c. in che Hantes Alpes, e.!., Abries, viii. 1n. 1900 (Tutt); the Basses Alpes, e.\%., Jigne, vi. 90, vii. 91 (l.mn.) ; Jamphiny Alps,

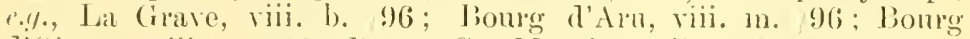

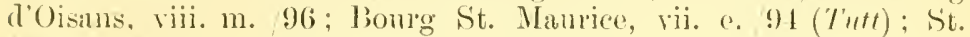
Martin Vesubie, Vallon Obscm, Re. (IMm.); v. c. in the Italian Alps, e.\%., Certosa di l'esio (Norris); Torre Pellice Valley up to 7000ft., viji. 01 (T'utt); Snsa (li.-lim.); J'ré St. Didier, viij. b. 98

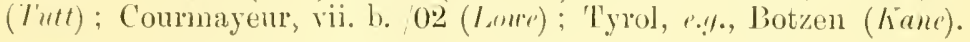
Directions of Yar. (a.) borter of small blk. spots up.s. h.w. $\delta$. ab. Punctulata, $11 \%$.

(b.) size and conspicuousness of or. spots up.s. in + , esp. at apex f.w.

(c.) tint of grd. col. un.s.

(d.) occasionally spots un.s. prolonged into dashes (lis.).

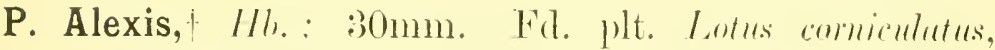

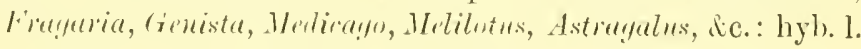
o brt. lilac-bl., \& bru. with or. margl. spots.

Dist. Char. extremely narrow blk. out-margl. line not continued round apex f.w. un.s.

Loc. Gen. distributed, often c., and sometimes ab., thongh by no means the commonest "blue" as in England. Found up to 7000ft. or eren more, ir.-x., in 2 and often 3 broods. My earliest date is Veytanx, iv. 399.

Directions of Yar. (a.) tint of grid. cul. in $\delta$ and amount of bl. in $q$.

ab. Pallida, Thit: of pale lilac-bl., $q$ bin., sharled all orer, exe. costa, with pale lilac-hl., pale wedge-shaped mark h.w., and often pale bl. marg. bordering the or. spots.

ab. Clara, T'utt: $\delta$ brt. bl. approaching liellargus, $q$ same col., with or. spots esp. f.w. almost obsolete.

Obs.-This appears to be an ab. of the lst broot.

ab. $q$ Cærulescens, $11 \%$. $q$ with col. of typical $\delta$ only on basal part of w's.

ab. $q$ Cærulea, Fms: $q$ with col. of typical of as far as the or. spots; mareg. brn.

+ Note- The utterly unscientific position that the first decribed form must he regarded as the type, can lardly hate a better illustration than is afforded by this sp. The \& Icarus, liott., only differs from the \& by its border of or. spots ups.s. If it be held, as it certtinly should be, that the name Icarus must be "pplied to this unusual form, then Hibner's name, Alexis, must be restored for the true type, a course wh. would hase the further alvantage of getting rid of alb. Iphis, Bahmh., and the consequent confusion with ab. Iphis, Meig. "Literary" types, as opposed to natural ones, are an unnecessary, if "convenient, "means of putting literature into opposition with science. 
ab. $q$ Icarus, Rutt. : $q$ col. of typical $\approx$, but with ante-margl. row of ol: spots.

ab. $q$ Semiclara, Tutt: $q$ with col. of ab. Clara at bases only.

ab. $q$ Angulata, Tutt; $q$ like ab. Pallilu, but with angulated row of pale bl. spots just inside or. spots f.w. up.s.

(b.) presence in type $q$, and ab. Cormlea $q$ of wedge-shaped mark and cl. spot up.s. h.w.

(c.) tendency to loss of spots un.s.

ab. Iphis, Meigen : with one basal spot only un.s. f.w.

ab. Icarinus, Siriba: without any basal spot un.s. f.w.

ab. Semi-persica, T'utt; spots on h.w. more or less obsolete.

ab. Persica, limmer: with all exc. the disc. spots obsolete, f. and h.w.

(d.) tendency of spots un.s. to unite or lengthen into strealis.

ab. Arcua, Far. : in wh. the lowest basal spot, f.w., is united with the lowest of the cl. row into a long bow-shaped streak.

ab. Striata, Tutt: in wh. the spots me more or less mited for prolonged) into streaks.

Obs.- These various abs. not having been sufficiently noticel, it is impossible to say whether all of them oceur in Switz. or the central Alpine region. The ab. Cismulen, Furhs, magnificent examples of wh. are in the collection of Col. Agassiz at Lausanne, is so strikingly different from the o. form of the $f$ with bl. at the base and slightly shinded over the centre of the ws., that 1 have ventmen to name the latter ab. licerulescens; this form may be found wherever the brn. type of appears. Ab. Arena is to be found in the Rhone Valley, and is e. in the neighhourhood of ligle and it. Triphon. Ab. lcarimes $1 m$ at be talien in the same locs. amongst others, and in vi. 98 was by far the commonest form at Veytaux; I have also a splendid ab. Strialu from the same place. Tulging from the analogy of other "blues," it would sepm mrobable that in the st. of the region shond also ocear

ab. Celina, thth.: I with maryl. row of blk. spotis up.s. h.w.

\section{P. Eros, (1/s. ('lithonus, Hb.) ; $29 \mathrm{~mm}$. Fil. plt.}

(and 1.) $111 \mathrm{k} 110 \mathrm{~m}$.

o lt. greenish-bl., \& blackish brn. with pale bl. at base.

Dist. Char. col. (between Corydon and Damon) in comnection with size; (un.s. v. like Aleris).

Loc. Principally in the Bernese, Valaisian, and Grisons Alps from about 4000ft. to 7000ft., vii.-siii. Pont de Nant (Trum), vii. 18, 27 (I:l.) : Glacier' de 'Trient; Pierre-à-voir; I)iahlerets; Crites de 'Thyon; Wrolena; Inden; Loèche-les-bains; Daubensee: Cromer (ilacier, de. (F'ar.); Simplon Village, vii. e. 99 (T'utt); Simplon P'ass, 10r. 1st gallery, viii. 698 ; 11 . 5th Refuge, viii. 1298 , ab., o rather later; vii. $12 / 01$, o and $q$; Steinenthal, rii. e. 9.), ヶ. ab. (I\%.); Saas, vii. 7-16/98; Zermatt, vi. 28/99 (ll/m.); viii. 9) 01 (Sloner) ; Riffelalp, vii. $/ 01$ (Lmn.); upper end of Lauterbrunnen valley, riii. 1, 1900 (II/.): Little Schejdeck (Fis.) ; 


Meiringen (.1\%-D) ; rather c. in Upper Engadine, Val liex, \&c. (Nirholsme); Pontresina, vii. /95, v. ab. (M/ss Fin.); Guarda, vii. $1900($ Chu.) ; Campfer, farily c. (Joues).

Abries, viii. m. 1900; Larche, vii. e. 1900; Le Lantaret, vii. e. 96 (Tutt); Gatp (Kume); Allos, viii. 292 (Norriv); leanvézer; Colmars (Pourell); Malmorte, vall.; l)igne; Faillefen; Biarcelonette (hane); Alpes Maritimes, not c. (lim.); Cogne, viii. 8-1291; Bobbie and Au Pra, viii. 1n. /01, al). (T'utt); ('ertosa di Pesio, from 6000ft., not c. (Norris); Kor Alp (Lmu.).

Directions of Yar. (a.) tepth of grd. col. $\delta$, cansed by more or less grn. in the bl.

[Ohs. - Specimens from the Lauterbrunnen Valley are smaller and bluer than from the Valais. Cf. Damon.]

(b.) amount of bl. on up.s. \& [tending towards ab. Cirrulescens, ()bth.].

(c.) tentency to disappearance of blk. spots of border un.s., culminating in :

ab. Petrividenda, far.: in wh. they are replaced by a wh, band.

Loc. Pierre-it-roir sur Saxon (Far.): v. close to this form, Anzeindaz $(F$ is. $)$.

ab. Subtus-radiata, (Obth.

(il.) spots un.s. oecasionally lengthened into streaks.

Loc. Riffel Alp (Far.).

P. Orbitulus, I'rmmer 26 mm. Fil. plt. anknown, the I. having only been discovered just before pupation; hy h. (? or.) or 1 .

3 slate-col., of slaty-brn.

Dist. Char. col. (\%. Inurlii), in commertion with great breadth of wh. romud blk. surts min.s.

Loc. On all the high Alps from s500)t. to soooft., rii.-viii., in more or less numbers: sometimes on moist spots many hmmireds may be seen at a time, $\%$. . Steinenthal, vil. 1101 (II\%.).

Directions of Yar. (a.) size of blk. spots un.s.

ab. Subtus-punctis-fortissimis, fiar: $m$ wh. they are v. large.

(b.) tendency to lose blk. centres of eye-spots un.s. h.w.

(e.) tendency to develop conspicuonsly wh. nervires 1111.s. f.w.

(d.) tendency to exhibit wh. spots up.s.

ab. Aquilonia, Lmer : disc. spot up.s. f.w. deep l,kk, triangnlar, on h.w. sinaller, romder and lighter, both surronuded with wh.: ante-uargl. row of wh. spots f.w. up.s., marg. brighter than grd. col. : r. faint eyes out. marg. h.w.; un.s. h.w. clear fawn. 
col.; the smoky markings at marg. obsolete f. and h.w., only one blk. spot nr. costa f.w.

Loc. Pilatus, vi. 601 (Love); apparently also the same form described by Frey ("Lepidopteren der Schreiz," p. 17), as being found occasionally in the Engadine.

Obs.-Mr. Lowe has another specimen from Pilatus, typical on up.s., but like the above un.s. $(v .($ b. $)$ supra. $)]$

(e.) breadth of ak. horder up.s. in $\delta$.

(f.) spots lin.s. occasionally elongated into dashes $(1+i r y)$.

P. Astrarche, lir!str. (Medon, lisp.; Agestis, /Hh.); $26 \mathrm{~mm}$. Fd. plt. Helianthemm inlyare, Trifolium, \&c.; hyb. 1.

Brn., \& greyer than $q$ u.s.

Dist. Char. col. in connection with size; no basal spot 111.s. f.w.; distinguished further from Alexis ab. Irrimus $q$ by entire absence of 1,l. from base of ws., and from others, e:\%., Emmedon, Hylas $q$, Escheri $q$, by the absence of their dist. chars.

Loc. (ien. consirtered an ab. as well as a widely distributed sp., and found up to an elevation of $7000 \mathrm{ft}$ or more; r.-vi. and viii.-ix. It appears not to be absent from any district, on rough, Howery pastures, wastes, and slopes.

Directions of Yar. (a.) tendency of red spots up.s. to disappear, culminating in :

ab. Allous, Hb. : in wh. they are absent.

Loc. Principally in the warmer locs. in switz. in 2nd brood.

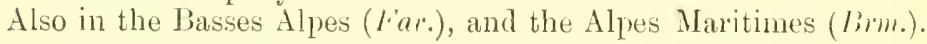

ab. Alpina, stmr.: also without reel spots up.s., but is smaller and of darker appearance.

(b.) Tint of gred. col. un.s. which in 2 nd brood is often bru., esp. in $q$.

var. Calida, liellier (Estiva, ittyr); in wh. the red spots are also large.

Loc. ('hiefly in hot valleys, e.\%., Rhone Valley from Martigny to Jirig $($ lor.).

\section{P. Pheretes, //h.; 28mm. Fd. plt. (and l.) unknown.}

o brilliant bl., \& brin.

Dist. Char. 1un.s. h.w. wh. patches in place of all eye-spots.

Loc. Confined to the high Alps, from about 5.500ft. to 8000ft.; not on the Jura, but r. widely distributed over the mtns. of Berne, Cri, Lnterwalden, Lncerne, Cilarus, St. (iall, Appenzell, Vand, the Valais, ant the Grisons, vi. e. vii.-viii. (F'ar., "Lépicloptères du Valais," spealis of it as somewhat scarce and local); e.!., Pont de Nant, vii. 12 (lil.) ; Arolla, vii. 11, 12, 1900, not c.; Saas, vi. e. 94; 


vi. j-15 9s (likm.) : viii.9 97 (li.-lim.) ; Zelmatt, vii. 10 !)!) (likm); Kinal, viii. 1 !s, c. on the Appitetta path (/.-/im.); on the Simplon Pass, not lower than the 5th Refuge, and not c. vii. e. 98, 9! (II\%.) ; m. Languard Falls, vi. e., c. (Vicholson) ; Pontresina, Silsel See, vii. 95 (Miss l'tn.); Schaflerg, vii. 2401 (Fiis); Fusio, rii. 1900 ; Guarta, vii. 1900; liennina Valley, llenthal, Val T'uoi, all v. ab., vii. 1900); Oberalp, viii. e. 95 (( \%/.); Miirlen, vii. e. 1900, c. $(11 \%$. ) , ice.

Chamonix ( $1 \%$ 'ar.) ; Faillefen, Larehe, vii. 1 (l'orrll); Tal J3igon. tina, viii. 1195 (Thtt) ; Cortina, rii. 20-25, 1900, r. ab. : Brenner, on the Postalp, Is preponderating, vii. 29, 1900; Stelvio, vii. 16, 1900 (li.-limn); Heiligenblut, vii. 2497 (Lum.).

Directions of Yar. (a.) Prilliancy of col. $\delta$, depending on presence of lilac tint.

(b.) \& bl. disc. spot up.s. f.w.

\section{ab. + Cæruleopunctata, $\| \%$.}

Loc. Pierre-itroir, 1 specimen ( $F a r$ ): Mniruen, vii. e., viii.b. 1900 , abont half $(\Pi \%$.).

(c.) tendency to loss of eye-spots f.w. un.s., culminating in :

ab. Maloyensis, Tiihl: in wh. they are absent.

Loc. By no means confined to the Maloja Pass, e.\%., Mürren, vii. e. 1900; Simplon Pass, vii. 1201 ( $\left.1 \mathrm{I}^{\top} h.\right)$.

P. Baton, lingstr. (Amphion, lisp.: Hylas, IIb.) ; $22 \mathrm{~mm}$. Fd. plt. Thymms serpyllum, 'T. rnlyaris, r'oronilla raria: hyb. p. (? sometimes as 1 . full-ferl).

б dull lightish manve-bl., $q$ dull dk. brn. with bl. of $\delta$ at bases.

Dist. Char. Col. and size, in connection with sharply-defined chequered fringe ( $r$. Hion and limaryns).

Loc. Widely distributerl, but in Switz. gen. isolated, or only a few together; so much is this the case that locs. are not likely to be v. reliable. 2 broods, iv. e. to vi. b., and vii.-viii., rising in the mtns., later brool only, to more than 7000ft., e.\%., Albula Pass

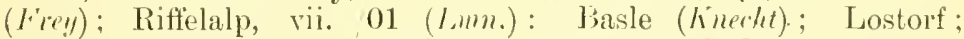

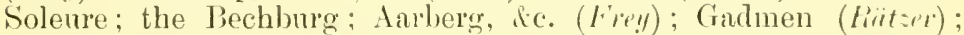
Vernayaz, iv. 30, v. 2602 ; Sierle, vii. m.; Big, vii. 24 99, c.; Bérisal, viii. 97 (1/\%.); Simplon, vii. e. (9!) (Thtt); Arolla, vii. 11, 1900 ; Saas, vii. 5-16; $9 \mathrm{~s}$; St. Nicholas, vii. 1.99, \&e. (lskm.); Veyrier, v. 26: Meyrin, vii. 26, kc. (Iil.); Pontresina, vii. 1900 ( $/$ l. ) : Locarno (lis.), ic.

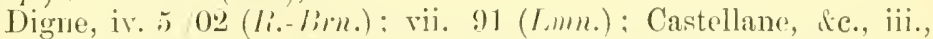
jy. and vii. (l'orrll); C'roda da Lago, viii. 11. 95: 'L'orre Pellice, viii. b. 01 (T'utt); Brenner, vii. 1900), a large form (li.-lim.).

Directions of Yar. (a.) size; specimens from Alpes Maritimes, v. much smaller than Siwiss.

(b.) un.s. size of likk. spots, esp. f.w.; gen, large. 
(c.) considerable darkening of grit. col. ฮे, culminating in :

*var. Panoptes, $1 / 6 .:$ in wh. the or. spots un.s, are also obsolete: v. sinall.

Loc. Cannes; (Hyères).

[Obs.-Some collector's well acquainted with these parts assure me that genuine P'anoptes is not formd there (umless as an oceasional ab.); v. small and dk. forms are c., but not withont or. un.s. h.w.]

P. Orion, Pallas ('Telephii, Esp.; Battus, $H b$.) ; $27 \mathrm{~mm}$. Fd. plt. Sedum telephimm and s. album: hyb. p.

o with broader borter than o 1 p.s. ; blk. with bl. on bases; broadly chequered fringe.

Dist. Char, un.s. h.w. continuous or, band.

Loc. N. of the S. Alps only in a v. restricted part of the Rhone Valley ( $v$. infrii); c. S. of the Alps in 2 broods, iv. v. and vi. m. vii. e.!., Locarno, iv. b. /99, v. ab., and vii. (c/p.); v.: Ingano, iv. 16 02 ; Val Anzasca, vi., Brusio, vii. e. (Fis.), \&c.

St. Michel-de-Manrienne, vii. e., just out (T'ntt); Chiavenna, vii.b. 1900 (R.-B m.) ; just above Crevola, vi. 2696 (Postuns); Orta, v. m. 1900 (Lomé); Lake ('omo, viii. 96 (Miss l'tu.) Pré St. 1)idier, viii. b. /98 (Tutt): Gorge de St. André, Nice, vi. 9/91 (lim.); Certosa di Pesio, vii.-viii. 92, c. (Norris); Botzen, vi. e., worn; vii. 14/02, presumably 1 st and 2nd broots (Lomer); Mölling, vii. b. 1900 (Lan!) ; Isonzothal, vi. m./92, c. on Monte Matajur (Norris).

Directions of Yar. (a.) size: from 24mm.-34mm. [Specimens of 1st brood from $\mathrm{S}$. side of Alps much the smallest.]

(b.) increase of bl. up.s., culminating in :

var. Ornata, Styr.; wh. has a good deal of hl. on disc. f.w., and a borcter of bl.-ringed eye-spots, up.s., most conspicnons on h.w.

Loc. S. Alpine Valleys, in 1st brood.

(c.) diminution of hl. on w. bases, cmlninating in :

yar. (and ab.) Nigra, (rerthard; in wh. the bl. has almost, often quite, disappearen.

o much larger and rather browner than $\delta$.

Loc. The usual Valaisian form, though the type is occasionally found. Only between Vernayaz and the Cranter, and mostly confiner to the neighbourhood of Martigny: Branson, at ft. of vineyards, v. 14, 1900, fresh; v. 1502, lather worn (Wh.); Fully, v. 22 01 , between 8.80 a.m. and 9.80 a.m., v. ab. ; S. of Plan Cérisier, vi. b. 02, 1st brood (lii.s) ; Vernayaz, vi. 26/01, 1 only, worn ( $\mathrm{klkm}$.$) ;$ Fovernier, Sion, (iringes, Sierre, entrance to Visp valley, and between the 2nd Refuge and Ganter Bridge on the Simplon (l'ar.);

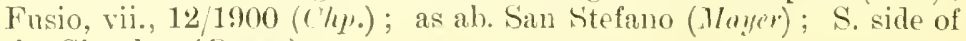
the Simplon (Riit: $r^{\circ}$ ).

Torre Pellice, viii. b. 01 ; Bobbie, viii., m. 01 (Tutt). 


P. Optilete, Kmoch; $27 \mathrm{~mm}$. Fd. plt. I'accinium uliginosum, 1. myptillus, ir. oxyromerus.

o ak. prp.-hl., of hrm.

Dist. Char. un.s. h.w. a conspicums metallic bl. spot at anal mng., bordered on inn. sirle by brt. or. crescent.

Loc. Gen. distributed on the higher Alps of I'nterwalden. Berne, the Valais, and the Grisons, but seldom e. Moors nr. Finsiedeln, vii.-viii. (Paul); the high alps round Nartigny, Bovine. vii. 25, Grand St. Bernard, \&e.; above the Mayens de Sion; the Gemmi; the Grimsel; the Furka, \&ce. (Far.); Belalp, vii. 11/94. one; between Kermatt and Riffelalp, vii. 10,99 (B/im.): above Kimal, at ft. of Durand Glacier, viii. b. 997 (Li-kim.) ; Simplon road, above th Refuge, vii. e.; above 5th Refnge, riii. b. $/ 98$ (Wh.) : Saas Valley, vii./85, a few, worn (. fomes); Miirren, vii. 24.

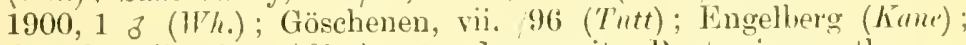
Guarda, vii. 1900 (Chp.) ; wood opposite l'ontresina, rather c.: Rosegg and Mtorteratsch valleys, nsually in peaty places (Nicholson); Morteratsch glacier, viii. 1/01 (F'is.); Campfer, on banks of Inn, a few ; more c. $1000 \mathrm{ft}$. higher (Jonss).

Le Lantaret, vii. 30, viii. 5/96; Pré St. 1)idier, viii. b. /98; Courmayeur, vii. e. $/ 94$ ('Tutt); S. T'yrol, vii. /95; Wolfsherg, vii. 14/97 (L,mm.); Kor Alp, vii. $17 / 97(\mathrm{r} / \mathrm{h} \%$.).

[Obs.-The usnal Swiss form is smaller than type and larger than Cyparissus (? var. Sibirica, Stgr.).」

Directions of Var. (a.) diminution of size, cuhninating in :

ab. (var.) Cyparissus, $1 / 6$. about $22 \mathrm{~mm}$.

Loc. Occasionally with type, e.!... top of Simplon L'ass, viii. b. /98; Miirren, viii. 11, 1900 ( $11 \%$.).

Chamounix; Larche, Lace de la Madeleine (Kanc): as val. only in N. latitudes.

ab. Subtus-radiata, F'at.

(b.) blk. spots un.s. occasionally replacet by long dashes.

(c.) occusional traces of additional metallic. spots min.s. h.w.

Genus, Rusticus, Hb. ('lebeius, Kirly, \&c.).

[On the authority of Sicudder and Grote, I have suppressed Plebeius as a generic name, as not having leen so used by $L_{\text {..] }}$ ]

Dist. Char. A more or less conspicuons wh. band mm.s. h.w. just within the peacock eyes.

R. (Kephyrus, Frimldstil) var. Lycidas, 'Trup. $33 \mathrm{~mm}$. Fd. plt. Astrayalns exocarpus.

o lilac-bl., o hm.

Dist. Char. 111.s. h.w. straight row of 4 nrly. equal-sized blls. spots across base.

Loc. Extremely local: Simplon Pass, just alove 2nd Refinge, 
ab., and thence to Ganter Bridge, vi. 2501 (Strin), vii. m. 98; vii. 801 (Wh.); same date 02 (Strldm), \&e., de.; from Visp to Stalden, Huteggen, Baltschieder, and Val d'Anniviers, vi.-vii. (F'ur.); St. Nicholas, vii. 1898 (Lome); vii. 1998 (ISlim.): Follaterre, vii. 2299 (I'schl.); (Gemmi, 2 o s (Standen).

Stresa, meadows nr. lake, vi. b. 87, a few; x. 99, a $\delta$ and $q$ smaller, presumably a 2 nd brood (.Tones).

Directions of Var. (a.) up.s. h.w. ठ, eye-spots showing or. edges.

(b.) up.s. h.w. $q$, absence of eye-spots.

(c.) un.s. h.w. tendency of wh. band to become less distinct.

(d.) shade of grd. col. un.s.

\section{R. Argus, L. (Egon, Srhiff.: Argyrotoxus, limgstr.);}

$27 \mathrm{~mm}$. Fd. plt. Trifolim, Grmista sroparia, (nnmis spinosa, Colntea arboresrens, \&e. : hyb. or.

[Obs.-The confusion wh. always seems to exist between this and the following sp. has been materially increased by the discovery that the name Argus, $L_{\text {., }}$ by which the latter has been universally known, onght to be applied to the sp. generally called. $\mathrm{Egm}$. It is greatly to be regretted that the discovery, wh. serves no scientific end, was ever made, or that having been made, the discoverer dirl not suppress the useless fact. Unfortumately it is but too little realized that nomenclature is only a means to an end, and that that end is the illustration, and, so to speak, the condensation of seientific facts, rather than a reproduction of the confusion of Babel.

8 lilac-bl., \& brn.

Dist. Char. of rather broad suffused blk. boriter up.s., o proportionately large eye-spots un.s., esp. f.w., and grd. col, gen. darker than Ary!nrommmm o, making the wh. band more conspicnons: some os are, however, difficult to distinguish.

Obs. - The claw on the front tibia of this sp. reguires a fairly strong lens to distinguish it, so does not afford a ready means of identification, though useful as at final resort. It is, however, il mere prolongation of the upper portion of the joint, and absurdly inadequate as a yentric distinction.

Loc. T. gen. distributed over the whole region in woods and clearings, on roadsides and riverbanks, alpine slopes and pastures up to the tree-limit: sometimes in endless profusion; r.-ri. and vii.-viii.; in the mtns. vii.-viii. only.

Directions of Yar. (a.) increase of size up to $32 \mathrm{~mm}$. (in the hotter locs.; the largest I have ever seen come from Sierre, and from the Rhone banks at lionveret).

(b.) diminution of size, culminating in :

var. Alpina, lirw: not exceering $28 \mathrm{~mm}$, sometimes less; 3 with rather darker grd. col.

Loc. The usual form in the higher mtns., '‘.!., Bérisal, vii.-viii. 98 , and vii. b. 02 , extremely ab. $(11 \%$.)

(c.) tendency to obsolescence of metallic spots un.s. h.w.

(d.) tendency towards disappearance of wh. band un.s. h.w. in $\delta$. 




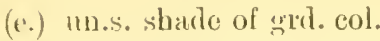

(f.) $\&$, atroumt of $01^{\circ}$. 11 p.S.

(g.) tendency to develop narogl. row of hilk. spots mp.s. h.w. $\delta$.

(var.) ab. Bella, /l....: with lighter un... (at transitional form is ab. in the Rhone Vialley).

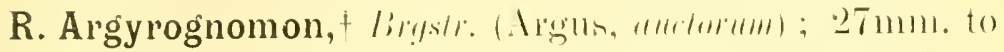

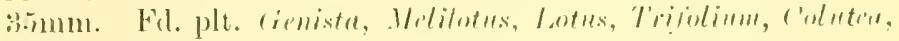
ice. : hyb. 1).

o lilac-hl.. o bru. with hl. mutiosion over at large portion of ws.

Dist. Char. o narrom well-defined blk. borker up.s., q proportionately small eye-spots mn.s.

Loc. Hore local than the preceding. but still widcly distributed, often c., sometimes ab., r.-vi. and vii.-viii.; in mutns.. only rii.-riii.

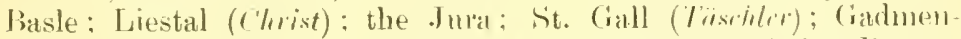

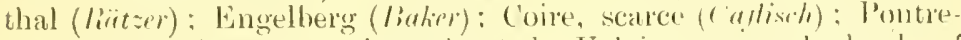
sina, vii. $84(1 \mathrm{~mm}$.$) ; c. throughout the Valais, esp. (on the banks of$ the Rhone; and in the high valleys, $\%$.. in immense mumbers at the Ganter bridge, vii. 98, ic. (11\%.).

Gen. distributed throngh the rest of the region.

Directions of Yar. (a.) size: largest gen. in hotter locs., Sierre, Branson, and larrer still from Mendrisio, viii. lis 02 (lik.). $3 \mathrm{~s}$ of $27 \mathrm{~mm} .-28 \mathrm{~mm}$. are usual where $q$ firmmon is found. 'The smallest constitute :

var. Egidion, Meissner; 2021111.-25nm, \& with rather darker gred. col. up. and un.s., $q$ gen. with some bl. up.s.

Loc. Gen. the min. form, but not to the exchusion of others. exc. the large $\delta$ and type $\mathcal{\rho}$, nor is Fighlion confince (exc. an var.) to the intus.; e.\%., Branson, with type not moncommonly. At bérisal, vii.-viii., it occurs in immense profusion, in abont equal numbers with of lirmume and the of of $271 \mathrm{~mm}$. (11\%.); so also on the Weissenstein ( $F(r)$ ). In the upper Engatine it replaces the type (Frey), so also at T'husis, viii. (I) (Miss l'tn.).

(b.) $q$, bl. extending over whole $\mathrm{ws}$. exc. border.

ab. \& Argulus, liry: of small si\%e, ar. 27nmm.

+ Note.-Standinger's use of this name (Cat., 1901, p. 7\$), with the bru. \& as the type, is indefensible. As Dr. Spuler (Dic Schmetterlinge Europas, 1902, p. 61) has pointed out, Bergstrïsser's sp. is figmed with the bl. \&, anl as this is quite a $c$. form (I should say the commonest), it is perfectly permissible to regard it as the trpe. (The case of Alea is is quite lifferent.) Dr. spuler suggests the name ab. ? brumnea for the brn. \&. The only objection is that the brus. ? is gen. asisociatert with a smaller and slightly darker" $\delta$, but as this is not invariably the case, I have. after much consideration, decided to adopt the suggestion. rather than the only alternative of adding to the alvendy existing confusion by re-manime this sp. In my own judgment it wouk be immeasurably better to retain the trulitional use of the names frgus and. Egon; it is probuble that Linneus regarted both as one sp. 
Loc. Scarce: Branson ; Sierre; Pfyn, vii. $15.01(11 \%$.) ; on the road to Alpien above the Simplon Pass, S. sicle (licitser).

ab. \& Unicolor, fav. A form of Argulus without ante-margl. blk. spots or or. edging up.s.

Loc. Gamsen; Martigny ; Fully (Ischl.).

(c.) absence of bl. in $q$.

ab. (\& var.) Brunnea, sumler. This having been hitherto recarted as the type, there is some confusion as to locs. It is, howerer, the usual form on the Rhone baulis between Bowveret and Martigny where it is replaced by the bl. form, and also in the mitns., though not exchusively, until replaced by Figirliom.

(d.) un.s. h.w. tendency of wh. band to become less conspicuous.

(e.) depth of grd. col. un.s.

(f.) extent of or. 11p.s. q, valying from a little on h.w. to borter f. and h.w.

Genus, Everes, $11 \%$.

E. Argiades, L'ullas (Tilesias, liott.: Anyutas, //l.) :

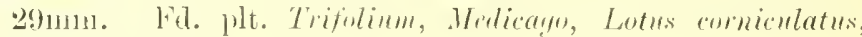
dic.; hyb. l.

of lilac-bl., of bru. tinged with bl.

Dist. Char. L.w. a tiny projection or " tail " nr. anal ancr. (much shorter than in Lamprites).

Loc. I. local in Siwitz.: Liestal ; Ziurich (Rom) ; locally thromgh

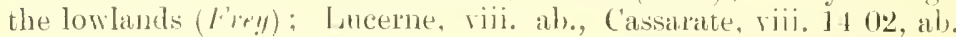
(lis.): l'inchat, viii.: Veyrer, rii. 13, viii. 1; Versoix, viir. 2!); Onex, ix. 2 (lit.).

Much connemer in the S., r.t., Gresy-sul-Aix, vii. 2.; 96; riii. 11.

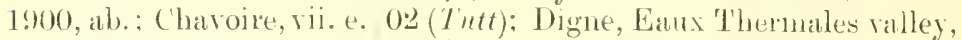
vi. 7 9!) (li,-lim.); Alpes Maritimes, c. in meadows (lirm.); C'ertosa di Pesio, a few os below ('hiusa, os in a large clover field about a mule away, viii. 18.92 (Norris): Susa, viii.m. 97; Coumayeur, viii. b. 91 ('lutt) ; Olgiate, riii. 95; Sondrio, viii. 96( Miss l'tu.); Lago di Loppio, vii. 31, 1900 (.Junes) ; Wolfsberg, vii. 1799 (Lmm.). Directions of Yar. (a.) dininution of size, culminating in : ab. Polysperchon, lirystr.: not mole than $20 \mathrm{~mm}$.

Loc. With type or with var. Coretes; usually considered an ab. of 1st brook, but 1 have taken it in the Pfynwald, vii. 21,99, and at Branson, rii. 19, 1900, as well as vi. 1 (102 in the latter loc.

(b.) loss of or. spots un.s. h.w. constituting :

yar. Coretas, M.k. q entirely bru. up.s.

Loc. The only form (exc. ab. I'ntysperchon) that I have exel' found in the Rhone Valley: the of seens r. sealce. I'fonwald vii.

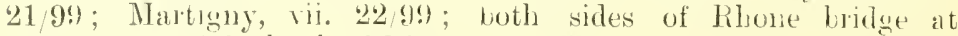
brancon, on right bank of hilone, V. 20,01, and vii. 19, $1900(11 \%$.). 


As ab., Digne, vi. 7 99 (li.-lim.) : ri. b. 90, c. but wolm, all of this form (. Fun's); Alpes Maritimes, c. in meadows (Rrm.); Mendel, vii. 9; $(\mathrm{l}, \mathrm{m}$. $)$.

Ols.-This sp. requires even more than ordinary care, being r. fragile.

\section{Genus, Cyaniris, IMlm.}

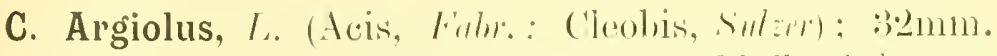

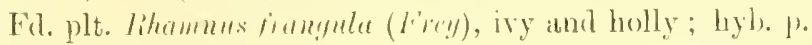
131. with slight like tinge, of with r. nallow, of with r. browl blk. marg. up.s.; brouldent in both sexes at apex f.w.

Dist. Char. Pale milky-bl. grd. coll. m1m.s., with small b,k. ditsthes.

Loc. Widely spread, but in sirit\% local and seltom c., of ten with r. restricted Hlight. I have only seen it in any numbers at Veytux, in the vineyards, r. and ix. 97; between Bonveret station and the Rhone, same dates, and under the cliff's opposite Vernayar, r. 2602 . Weissenburg, r.e., r. c. $(H ! ! \cdot)$; nr. Sion, r.e., r.e.

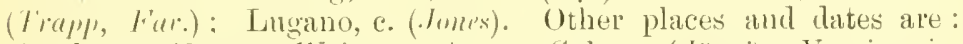
(iöschenen (R..S); Weissenstein, nr. Soleure (.Jitygi); Veyrier, ir.

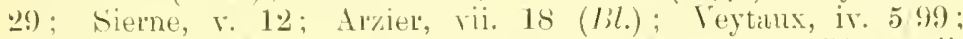
Vermayaz, ir. 2202 ; ix. 802 ; Lavey, r. 2902 ( $11 \%$.) ; Sépey, rii. 01 (imi.); Loèche, inr. Sierre (F'ur.); Honte (ieneroso, vii. s8

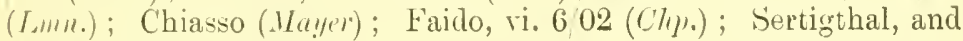
Tal Bregaglia (Killias).

Digne, i*. e. 97 (Tutt); ri. 90, vii. 91 (tmu.); Alpes Maritimes, e.f., V'allon Obscur, e.; St. Martin Vésubie, scarce (Irrm.); the Esterel, ir. b. 0:3, c.: Auribean, iv, b. 03 (Tutt) ; Monnetier, vi. 4; le Coin, ir. 2:3, v. 11; Mt. de Sim, vii. 29) : liossey, r. 28 (lil.); Wolfsberg, vii. 1997 (Lmu.).

Directions of Yar. (a.) size: 2.5mm. to $3.5 \mathrm{~mm}$.

(b.) decrease in size of spots in.s., culminating in :

ab. Paryipuncta, l'inchs; a form o: the summer brood with few and small spots.

\section{Genus, Lampides, $/ / l_{1}$.}

Dist. Char. un.s. streaked with brn. and wh.; h.w. with slender "tail."

L. Bœticus, L.. : :3:3mmm. Fil. plt. pods of colulin and other lemminimser': hyb. or.

o prp.bl., of dk. brn. with brt. bl. on disc.

Dist. Char. 1111.s. fium-col. and wh.

Loc. In Switz. only isolated specimens exe. in the Rhone

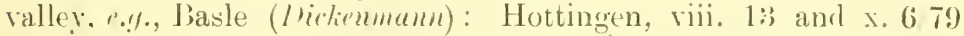
(Surll) ; Lausanne (Lahurpe). Not v. uncommon below Follaterre (on ('ulutea), viii. 18.24 93 (F'ar.); viii. 21 99, al), but mostly rather

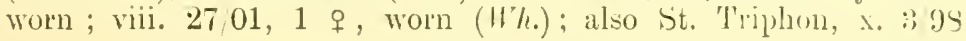


(Fis.) ; Sierre, viii. 19/99, worn, and viii. 3199 , in good condition ( $\mathrm{Wh}$.) ; Aigle ('Taslier) ; Geneva, vii. (I ll.).

Grésy-sur-Aix, viii. 22, 1900 (T'utt); Stresa, x. 13/99, c. (.Jones); above Beaulien, v. worn, x. 9/02 (L..lirn.) ; St. Maurice, Cannes, scarce ( $\mathrm{Bm}$. ) ; San Dalmazzo di Tenda, ix. 92; Bordighera, r. 92, fairly c. (Norris); Susa, viii. m. 97 (T'utt).

Obs.-Standinger is mistaken in speaking of linticus in the Valais as "alvena"; it is to be fomd in the stme spots every year, and in all stages, 1 have titken both 1 . and $\mu$.

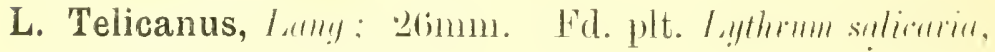
heather, de.: hyb. or.

bin: \& glazed with lilac, \& brt. lilac at base (spots of mos. show through).

Dist. Char. un.s. nouse-brn. and whitish.

Loc. V. scarce in Swit\%: opposite la Croix, Martigny, nr. the Dranse, x. (H'shl.) : also larve; 'Trois Torrents, vii. 94; also Cassalate, rili. I 1 , 02 ( F'is.) ; every year in gardens in and round Geneva, f.!., (ienera, rili. 30 ; Hermance, vii., Pinchat, vii. (lil.).

Digne, vii. 91 (l,mm.); Nice; Vallon Ubscur; Val des Fleurs; Valley of Mantegna; St. Martio Vésubie, a few, ii. to x. (limm.); (astellane, rii. 17.91 (Nirholsm): Certosa di Pesio, vii. 1892; c. later round the beinette springs; San 1)almazzo di 'T'enda, ix. 92, v.c. on flowers of Aster amellus; Bordighera, e. throughout $x$. (Norris).

Tribe 'THectur.

Genus, Callophrys, lillliri!.

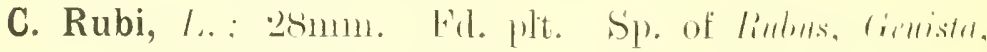
l'arinimm, de.; hyl). J.

o with, o without a scaleless-looking oval fatch 111. costa, up.s. I. Ir.

Dist. Char. Gru. un.s.

Loc. I'. gen. distributed and mostly ab., even at 7000ft., r.\%., e. at top of Rocher's de Naye: rii.-r., in the lowlands, vi.-vii. in the 11ntus. My earliest date is leytaux, iii. 17 99. In Switz. it appears not to be double-brooded.

Directions of Var. (a.) tendency to disalpearance of wh. line un.s., culninating in :

ab. Immaculata, f'rels: : wh. is entilely without it.

Loc. Oecul's occasionally with type, ".\%., Vacallo (Maycr); Rochers de Naye, vi. 101 (11\%.).

Obs.-An ab. with the bale patches up.s. f.W. Ochreous was taken at legrier by Prof. Bhachier, who has another (from Morocco), in which they atr dk. bin.

Genus, Læosopis, limlı. (Aurotis, Imlm.). 


L. Roboris, Fisp. (Frippus, //h.): $36 \mathrm{mmm}$. Frl. plt. oak.

o with prp. reflections over grenter part of f.w. and half h.w., $q$ only along inn. marg. f.w.

Dist. Char. Border of metallic-lilac-edger peacock eyes on brn.gr. un.s.

Loc. Digne, vi.e. and vii. b. 99, v. local and not c. (Miss fitn.): at Villard it reaches more than 3000ft.; Annot; Entrevanx, vi. 3001 (Povell); St. Martin Vésubie un high road to Nice, 2 miles from village in oak copse off' road (Brm.); vii. /01, v. ab.. o s until vii. m., after which os became more ab. (Lam!l).

Directions of Yar. (a.) number of prp. spots up.s. b.w. ( o 2 or 3 , \& up to 6).

Genus, Zephyrus, Ilılm.

Z. Quercus, L..: :34mm. Fil. plt. oak (and ash); hyb. ov.

o with prp. reflections over all ws., $f$ with deep metallic bl. on base and inn. marg. f.w.

Dist. Char. Pale gr. un.s. with whitish line and 1 or. eye-spot h.w.

Loc. Distributed over the region wherever the oak is found, and not rising higher than its fd. plt. grows; vii. to viii. $\mathrm{m}$.

Directions of Yar. (a.) size : occasionally as small as $291 \mathrm{~mm}$.

(b.) a yell. spot at end of disc. cell np.s. f.w.. constituting :

ab. Bella, firhurd: a v. rare ab.

(c.) depth of markings un.s.

Z. Betulæ, I..; ;(imm. Fil. plt. sloe and plum; hyl. or. 3 without, $q$ with brt. or. band up.s. f.w.

Dist. Char. mn.s. h.w. two wh. lines, the inn, extending only half across the $w$.

Loc. Sprear over the whole rearion in the lowlands, rarely mounting to any considerable heiglit, lont e at 'Tarasp, foooft. (Fillia.s). and on Xonte Generoso, boooft. (Jemmer), viii.-ix.

Directions of Var. (a.) o oceasionally with 1 large and 22 small yell. patches up.s. f.w., known als :

ab. Spinosæ, (rirhard.

Obs.-A 1 rate form in which the prtches are wh. is name: :

ab. Pallida, 'T'utt.

(b.) \& with yell. band, ife., instead of ol'.

ab. F Fisonii, Wh. : specimens of wh. have been taken at (Charpigny (l'i.i.). 
Genus, Thecla, l'ihr.

Preyailing col. dk. brn.; hyb. ov.

Dist. Char. nn.s. wh. line on Ik. (in Arariw darkish) brn. grd. col. Obs.--This genus, even more than the other Therlidi, is v. difficult to take in good condition and is v, easily spoilt in setting.

T. W-album, knorh: :30mm. Fil. plt. elm (and lime).

o with, $f$ without small oval smooth patch nr. centre of costa up.s. f.w.

Dist. Char. un.s. h.w., wh. line makes a clearly defined $\mathrm{I}^{\dagger} \mathrm{nr}$. anal ang.

Loc. Local, and only at low elevations, but not rare where elms are found; rii.-viii. b.; c. at Berne, in the lime avenues; Burgdorf

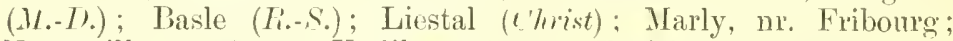
Nenveville ('ouleru); Uetliberg (H!.); Zürich (Zll.-I)ullr); at Weissenburg the commonest Therla $\left(H_{!} \%\right)$; on the E. slope of Pilatus, viii.b. 01 (hemmes); on both roarls from Aigle to Sépey, settling with other Theclas on Samlmeus elulus, vii. 22, fresh, 29, worn, 97 ; vii. 18,1900 , and viii. b. 01 ( $\mathrm{H} \%$.) ; beyond Sépey, rii.

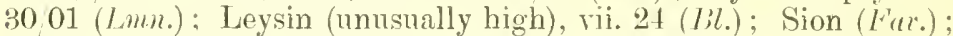
Sierre, vii. b. 97 (T'ustans); Geneva, vii., Bois de Veyrier, vis.; also on the Jura at St. Cergues ( $\mathrm{Bl} l$.$) .$

Cannes, Nice, not c. ( $\mathrm{H} \mathrm{m}$. $)$; Certosa di Pesio, not uncommon in $\mathrm{Tal}$ Pari, Val Sestrera, and Val Cavallo, vii. „24, viji. 6 92 (Nmmis).

Directions of Var. (a.) size, esp. in $q$.

(b.) depth of gxd. col. (often, however, depending on freshness).

(c.) tendency to narrowing of wh. line, culminating in :

ab. Butlerowi, Kmolilinglisti; in wh. it is so intermpted as not to form a $1 \mathrm{~T}$.

Loc. With type,.$\%$, Sépey road, vii. 2201 (IT\%.).

-(1.) with broad wh. line un.s. (at Nice, Cannes, \&c., Bim.).

T. Ilicis, Lisp. (Lincens, Fitlr.); :3:3mm. Fd. plt. oak. elin, dic.

$\delta$ (type) withont, f with or.-lim. patch on ont. half f.w.

Dist. Char. 11 . s. h.w. thin broken wh. line, and entire alsence of $b l$.

Loc. '2 brools, at any rate in some years. Onex, vi. 21: Teyrier, vi. 24; Jois de Bay, ri. 24; Meyrin, vii. 26 (lil.); c. in Vant (M.-J.); ‘.\%. Glion, vii. (01 (Lmm.); Sépey road, vi. e. vii., ab. (I\%.) ; all roumd Martigny. Saillon, Sion, Sierre, and molunting orer toonft at Evolena ( $F^{\prime}\left(1{ }^{\circ}\right)$; Srig, ix. b. 98 (J/.); Thasle (Kurht); Liestal ('hist); on the Jura; scarce at St. (iall and 'Ziirich (Titschler); Coltura (liazzigher). 


Grésy-sur-Aix, vii. e. 98 ; nr. Chavoire, vii. e. 02 (Tutt); Digne, vi. 4, lic., 99 (li.-lirn.); Certosa di Pesio, vi.-vii. 92, on thowers of wh. Sirlum. (Vurvis); Jotzen, vi. e. 01 (Imre); Mentel l'ass, viii. h. !) (l'utt).

Directions of Yar. (a.) size : from $31 \mathrm{~mm}$. to $35 \mathrm{~mm}$.

(b.) enlargement of or. patch, culminating in:

ab. (\& var.) Cerri, $/ 16$.; gen. larer, o with small, 9 with $v$. lareve or.-brn. patch.

Loc. Aigle, vii. 97, and /01; Sierre, vi. m. and e. $99(W /$. $)$ : Ttznach, vii. 50 01 (Fis.).

Digne, vi. 4, ic., 99 (R.-lim.) ; Alpes Maritimes, to the exclusion of type (l,mm.) ; Botzen, vi. e. 01 (Lom.).

(c.) tendency to lose the wh. line un.s., culminating in :

ab. Esculi, Hh.: in wh. it is wholly wanting on f.w. and occasionally on h.w. also.

Loc. Aigle (II \%.); Pfymald, vii. $9 / 98$ (likm.).

Digne (li.-lim.); Nice, ic. ( B im.); Certosa di Pesio, vi.-vii. !le (Noris); Sinsa, vi. 1802 (Lour) ; Botzen (Kam).

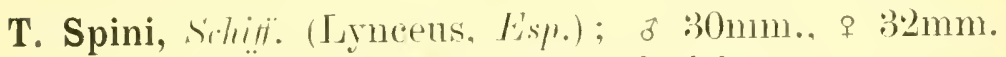
Fi. plt. Prmus spinesa, hawthorn, buckthorn.

o with, o without small, oval, bare-looking spot nr. costa, up.s. f.w.

Dist. Char. large bl. spot anal ang. un.s. h.w.

Loc. Widely spread throughout the region, chiefly at lower elevations, but mounting up to IO00ft. ol more: (vi.) vii. to riii. m. Jiasle, Liestal (('hrist); /iurich ; Ireissenburg, not c. (/!!.);

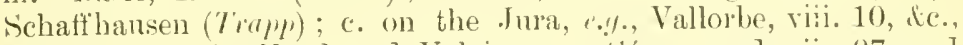
$02(11 \%$.$) ; c. ju V'aud and Valais, \because . \%$, Sépey road, vii. 97, and 01 ; ab. (II\%.) ; Martigny, Sierre. Varen, Brig, de. (Fu*): leenk,

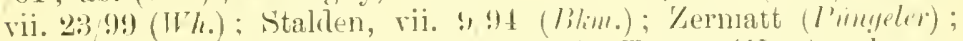
the (irisons, e.\%., Alveneu, vii. s.) (Imm.); 'Tarasp (Kam') also nr. Geneva, Veyrier, vii. 13 (Jl.); Jrimnen, viii. 96 ; Monte Salvatore, vii. 96 ('T'utt).

Grésy-sur-Aix, vii. e. $98\left(T^{\prime \prime \prime t t}\right)$; Monnetier, vii. 27. \&c. (lil.) ; Chavoire, vii.e. 02, worn; Bourg St. Mamrice, vii. e. 9s; Abrics, viii. 11. 1900; Larche to Barcelonette, viii.b. 1900 ('Lutt); Digne, vi. 4 (9), v.c. (li.-lim.); vij. 91 (Imm.); St. Martin Vúsubie; Valley of the Matone: Salme de la Fréma, 7500ft. (!) (lirm.); Commayemr, viii. m. 9s; Pré St. Didtier, viii. m. 9s; Cogne, viii. 7-1. \$1 (Thitt) ; Certosa di Pesio (Nomis); Inake Como, vi. (9) (Miss Ftu.): Bormio, the New Paths, vii. 11, 1900 (li.-lim.); Cortina. fairly c. and fine, vii. m. 1900 (Jones); Falzarego Pass, viii. 69) (Tutt): Mendel, vii. 95; Sit. Paul, Carinthia, vil. $1797: 11$ olf́sherer. vii. 97 (Lmu.) ; Mötling, vii. 97 (Miss Ftu.).

Directions of Yar. (a.) number of or. spots anal anc. mp.s. h.w.

(b.) $q$, large or. spots up.s. f.w., constituting: 
ab. \& Lynceus, Hb.: which on un.s. has the or. diminished. and the bl. spot v. large.

Loc. Digne, vi. 499, de. (li.-Hm.) ; St. Martin Vésnbie, rare (1 Mm.): Certosa di Pesio, (. in 2nd brool, vii. e. 92 (Nomis); Botzen, vi, e. 01 (l,me).

(c.) broarler wh. line un.s.

Loc. $S$. of Alpes Maritimes ( $/ 3 m$.).

T. Pruni, L. : $32 \mathrm{~mm}$. Fid plt. blackthorn, oak, ice. o with, $q$ without indistinct oval patel nr. costa, up.s. f.w. Dist. Char. un.s. streak silvery-bl. instead of wh.

Loc. Scarce and local; vi. m. to viii. b.: lBasle; Liestal (Christ); on the Aargau Jura (Hschl.); St. Haise; Nenveville (comleru); Aarberg; Schiipfen (linthubar/h); Lausanne; Orbe (Laharpe); not rare at Schaffhausen (Trap'p); Türich, vii. /95 (Lmm.) ; IVeissenburg, New liatbs, scarce (/I!.) ; Coire (Killias); Chonlly, vii.; Meyrin, vii. (Bl.); Aigle, vii. b. /97 (II/.) ; St. Triphon (Fis.) ; Martigny; Sierre; Noës; Corin (Far.). Mendel, vii. /95 (Lmm.).

Directions of Yar. (a.) number of or, spots up.s. $[\delta$ has gen. 2 or $: 3$ on h.w., none on f.w.; $q:{ }^{2}$ to 5 on h.w., 2 or 8 on f.w.

T. Acaciæ, finlı.: 228mm. Fd. plt. l'runns spinuse (gen. the smallest and worst bushes).

of without. \& with small or.-bru. patch up.s. f.w.

Dist. Char. mu.s. lighter wri. col. than other sp.: wh. line in $\delta$ gen. forming no ang. at anal ang. of wing. ('The bare patch in of is also nearel to base: I distinguished from llivis o by much lightel" grd. col. 11p.s. ats well as mll.)

Loc. Local, and scarce even where it occurs: vii. Lake of Bienne, Macolin, and 'Twannber's, in the vineyards (liothmbach); nr. Oftringen and Aarherw (Hschl.); liasle (hnecht); Liestal

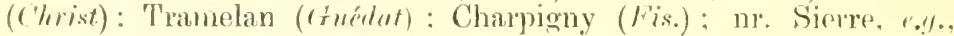
Corin, Noës. Nionc (liar.) ; Veyrier. vi.-vii. of (l/.).

Digne, vi. e. 99 (M/iss fitu.); nl. ('ondamine, vi. 24 ; Parce-

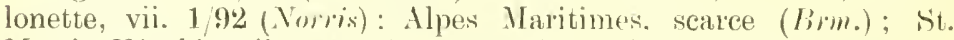
Martin Vésubie, vii. 1702 (l'wrell); Susa, vi. 27, 1900 (li.-lín.).

Directions of Yar: (a.) number of or. spots up.s. h.w.

\section{Fam. LEMONIIDE.}

Sub.-Fam. NIJlolilN.

Genus, Nemeobius, stph.

N. Lucina, I. : $28 \mathrm{~mm}$. Fil. plt. primrose, also varions sp. of limmer.

of with 6 , o with 4 walking legs. TThe lt. markings in the 


f are gen. so much more conspicnoms than those of the $\delta$, that the latter gen. appears to be ak. ln'n. with or.-brn. macular bands, the former or.-lmon. with r. llk. bru. markings.

Dist. Char. nu.s. h.w. 2 hands of wh. spots, the basal one broken helow the centre.

Loc. Thronghout the whole district from Digne to Wolfsberg, and from Liasle to the Alpes Maritimes, but becoming scarce in the latter loc., and not rising much above $3000 \mathrm{ft}$., iv.-vi.

[Obs.-. It must occasionally be partially double-brooded, as Dr. Christ took it ut Leeco, viii. /79; ME. Tutt at Grésy-sur-Aix, vii. e. 977 ; and Miss Fomtaine at Olgiate, ix. /193.

Directions of Yar. (a.) extent of tk. col., esp. h.w., in o , in which it sometimes almost obliterates the tawny markings; the blk. dots $11 \%$. out. marg. sometimes unite into a band.

(b.) suppression of margl. row of blk. lots in q, culminating in :

ab. Obsoleta, Tutt: in which they are all absent f. and h.w.

\section{Division. PAPILIONIDA. Fam. PAPILIONIDÆ.}

Tribe Paphionim.

Genus, Papilio, I.. : hyb. 1).

Prevailing col. yell. and blk.

Dist. Char. al long "tail" nr. anal. ang. h.w.

P. Podalirius, l. (Sinon, $I^{\prime}(r d e): 75 \mathrm{~mm}$. Fd. plt. sloe, plum, and other frnit trees.

of gen. larger than 8 .

Dist. Char. up.s. f.w. 2 black transverse streaks entirely crossing cl. portion.

Loc. Gen. distributed over the whole region in 2 brooks, r.-vi. and vii.-viii.; exceptionally both earlier and later, fomd ul) to about $4000 \mathrm{ft}$. At Digne, 1st brood, iv. $6 / 02$; 2 nd brood, vi. 499 : one at Col di Tenda, x. 702 , v. woln (li.-lim.).

Directions of Yar. (a.) size: exceptionally from $50 \mathrm{~mm}$. to 78imm.

(b.) tendency to whitening of wrd. col., colminating in :

ab. Feisthamelii, /m., with ante-margl. band f.w. and margl. lunnles b.w. ol. (but much lose so) in Swiss than in Spanish specimens).

Loc. Martigny, Fully, both broods (Far.); Sierre, viii. e. ક9

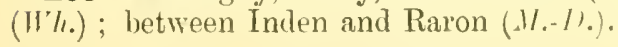


ab. Zanclæus, Zll., pale like last, but with abdomen wh. on up.s. instead of blk.

Loc. Martigny to Raron (l'ar.), 2nd lrood only. A transitional form with baly not quite wh. is not uncommon in the same district, ध., Pfyn, vii. $2199(\mathrm{H} /$.$) . (ien. ?$

Crevola $(F a r$.$) ; and dombtless other S. valleys of IV. Alps; Alpes$ Maritimes (lim.).

(c.) np.s. h.w. the long blk. streak divider by brt. ol. line, constituting :

ab. Ornata, $W \% . ;$ wh. is v. c. in Rhone Talley.

(d.) an extra blk. streak up.s. f.w. on basal sitle of longest streak.

ab. Undecimlineata, Eimer.

*P. Alexanor, Esp.: $64 m m$. to $76 \mathrm{~mm}$. Fd., plt. Sesile montanum, and other Imbellifera.

$q$ gen. larger than $\delta$.

Dist. Char. mp.s. f.w. on blk. streak entirely crossing cl. portion.

Loc. [Lam!) (Butterflies of Europe) gives Switz., but I can find no locality, nor bear of any capture.

Digne, vi. 13, and c. vi. e. und vii.. fond of settling on thistles (Jomes); above Laux Thermales (Digne), vi. 18, de. 99 (li.-lim.); Sit. Martin V'isubie, on the roar to Venanson; Valley of Madone; and less c. to La bollene (Brm.); Castellane, vii. 1791 (Virlorlson); Beanvézer, Annot, vii. 1.13 (l'mell) ; between Allos and St. André, vi. e. 92 (Norris).

$\mathrm{V}$. constant exc. in size $(r$ sum

P. Machaon, L..; $75 \mathrm{~mm}$. Fd. plt. wild carrot and other l'mblliver'.

of gen. larger than of.

Dist. Char. up.s. f.w. broad blk. hase, thickly sprinkled with yell.

Loc. Cien distributer and often ab. up to jo00ft., less ab. above, but found occasionally much higher: iv.-vi., and vii.-viii., a.!., Lugano, iv. 1296 (li.-lim.); Pex, iv.e. 97 (IVh.); summit of la Palette, 7180ft., viii. 9s (.tmus); Stelvio, 7680ft., vii. m. 1900 (li.-lim.); top of (hamossaire, 69toft., vii. 02 (1/oss).

Directions of Yar. (a.) size: 58mm. to skmm.; spring broor gen. mech the smaller.

(h) increase in tepth of colouring, culminating in :

ab. Burdigalensis, Trimomlet (Anrantiaca, Syr.) ; in wh. grrl. col. approaches or., and anal spot is much less red.

Loc. Valaisian Alps (Far.) ; nr. Ginelwald, riii. 1 1900; Aigle, viii. 211900 (I/\%); ('harpigny; the Jura (F'is.); 13otzen (Kane). \&e.

(c.) Aiminution of colonring:

ab. Flaya, Tutt; gril. col. pale primrose. 


ab. Pallida, Thtt: gril. col. alnost wh.

Obs.- Both these abs. are conspicuonsly wanting in tk. markings un.s.

(A.) increased heaviness of blk. mankings.

ab. Sphyrus, 1/h. (Saharar, (H,th.: listiva, Fimm); Mp.s. blk. markings broater, m.s. more mst-col. spots, and larger bl. ones : "tails" shorter, size surall.

Loc. Alpilles, Jenr-13rîlée, vii. (Ilswhl.); ic.

ab. Nigrofasciata, listhle; with broal blk. borler almost covering the bl.

Loc. With type, but v. rare: and as it has heen obtained by freezing puper, only to be expected in tho hightest haunts of the sp.: Yermatt (A!.).

ab. Rufopunctata, $W \%$.

(e.) or.-rerl spots in yell. lumules of border up.s. h.w., esp. nr. costa, constituting:

Tribe ThıїD.

Genus, Thaïs, Fithe: Fd. plt. Lristeluchin: hỵl). p.

Prevailing col. yell. and lik. with red spots.

Dist. Char. conspicuous dog-toothing, ont. marg. up.s. esp. h.w.

T. Polyxena, Srhiff. (Hypermmestra. Sropmli: Hypsipele. Fullir.: Rumina, lisp.) ; $60 \mathrm{~mm}$.

o larger than of.

Dist. Char. not more than 1 red spot up.s. f.w.

Loc. Formerly in Tessin ( $F^{\prime}$ ss $\left.l_{\text {. }}\right)$. It may he found again, just as $L$. Bonticus was: esp. as it was taken in some numbers by Trall. in the vineyarls at Orta, vi. 19/57. Like all the genus it flies $v$. early in the day, and is seldom sepn after 2 p.m.

Directions of Yar. (a.) tlarker colomring.

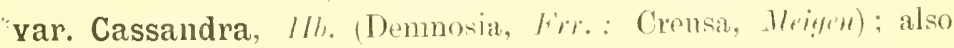
smaller. $50 \mathrm{~mm}$.

Loc. Dime and ('hâteanfort; Saroie (K'un'); Vence: Cagnes; nr. month of Loup: Camnes; on mashy grif, and thies only a short time (lim.); Mouth of the Roja, iv. M (Nomis).

Obs.-11r. A. H. Jones remarks that the emergence of this sp. depends enceatly on the season: it was fairly c. at Hyeres, s. b. ss, but entirely over and the larre full fed by $\mathrm{v}, 6994$.

(b.) rent spots replaced ly yell. lighter than girt. col.

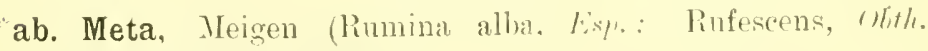
Flavomaculata, sirilile).

(c.) absence of reet spot inn. mare. up.s. f.w.

T. (Rumina. L.) var. Medesicaste, Illiyer (limmina, Ill,: Rumina australis, Es.p.) ; t.rmm. 
q larger than $\delta$.

Dist. Char. "y red spots mr. costa up.s. f.w.

Loc. L'Esterel, iv.-r. (l'mell); ('rasse (hane); at Hyires as early as iir. 18,02 (stoper), as late as v. b. 90 (.lomes).

Jigne, iv. 702 (I..-lim.) ; v. (sloper) ; vi. 799 (L.-l;rn.) ; esp. Aly hill-side behind cemetery. Mr. A. H. Jones formd both the butterfly and the larva in all stages, vi. b. 90, the young 1. on the un.s. of the leaves and in the tubes of the Howers of Aristolorhin pistolockia, the full-fed 1. concealed at the roots.?

Directions of Yar. (a.) presence or absence of red spot nr. inn. marg. up.s. f.w.

(b.) increase of red on h.w.

ab. Honoratii, B.rle. : in wh. the dise of h.w. 11p.s. is more or less covered with red.

Loc. So far, from Digne only, in varying number's, ‘./., 16 taken in $/ 95$, only 1 in 96 (Tutt).

Tribe Parnassidi.

Genus, Parnassius, lati.

Prevailing col. wh. with l)lk. (and gen. red) spots.

Dist. Char. f.w. with transparent ont. marg.

Obs.-The \&, after pairing, possesses a remarkable abdominal sac, the ust of wh. is as yet unknown. :

P. Apollo, L.; 75mm. Fd. plt. Sinhum telephium and S. allum, rarely Savifraya ä̈sö̈des.

o with v. hairy, \& with nearly smooth abdomen (sac $1 \mathrm{k}$. brn. small and holny).

Dist. Char. wrd. col. milly wh.; antenna not annulater ; gen. red spots h.w. only.

Loc. Scarce in the N. plains of Swit\%, but ab. in the Rhone Valley, and gen. on the lower slopes and in sunny gullies throughout the region; gen. less c. above $5000 \mathrm{ft}$. but rises to $8500 \mathrm{ft}$. at the Schwarzsee above Zermatt, and is c. at 7000ft. on the Simplon, and still higher on the Albula. It soluetimes emerges as early as iv. P. (Har.), and lasts till ix.m. (1/\%.), often in good condition, though there is only one broor. Its most nsual time for emergence is vi. and vii.

Directions of Yar. (a.) size: average specimens from the Jura are said by f'ar. and $1 \%$. $/$ ). to he larger than those from the Alps, but are certainly not larger than those from the neighbourhood of the Rhone Valley. Sipecially tine above Susa, vi. 24/9!) (li.-Jim.); large at Abriès, vii. m. 1900 (Tutt); v. small and approaching lylins in the Torre Pellice valley, viii. 01 (T'utt). The largest alpine specimens look small compared with some of the Spanish examples from the Albarracin district $((\%) \cdot)$.

(b.) size of spots, culminating on the one hand in: 


ab. (\& var.) Carpathica, liebel: with $r$. large costal spots up.s. f.w. : and

ab. Wiscotti, (Hth.: with v. harge spots Il).s. h.w.; and on the other hand in:

ab. Novaræ, (Jhth. : without spots up.s. h.w.

(‘) blk. spots mp.s. f.w. joined into a band.

(d.) absence of wh. centres to red spots.

[Obs. - Kine (Europen Buttertlies, p. F) wonld seen to imply that the wh. pupils are peculiar to the 'yrenees, but it is eertainly the usual form; the other is searce. There is a mannifieent example with v. large red spots in Mr. Fison's collection. !

(e.) col. of red spots, varying from lurt. crinl. son through lt. red. and or. to :

ab. Nexadensis, ()blt.: in wh. they are yell.

Loc. (Oecurs as rar. in S. Spain); as ab. in the Alps, e.!.,

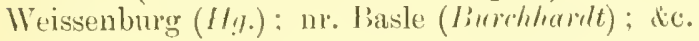

(f.) presence of a red spot or spots, f.w. constituting :

var. Pseudonomion, ' 'hrist: wh. has always a red spot, gen. double, on inn. maren. nu.s. f.w. and usually one outside the disc. cell; the latter of wh. is gen., the former sometimes reproduced up.s. The long spot nr. anal ang. up.s. h.w. is also gen. red; this sometimes occur's in other forms.

Loc. The usual form on the Jura where it is v. ab. : not yet out. vi. e. 02 ; but rather worn, though ab., viii. h. $02(11 \%$. $)$; found as an ab. elsewhere ; e.!., Brusio, vii. $17 / 01$ ( /'is.s.).

(g.) occasionally 2 wh. pupils in cl.spot 1 p.s. h.w.

(h.) $q$, tendency to darken greatly up.s., uslatly dk. in the Valatis, culminating in :

\section{ab. \& Brittingeri, lirbel.}

Loc. Principally in the I.. Alps, but also in the Engadine, the Vilais, dic.

Obs.-A specimen from the Albula Pass has the 2 rer spots h.w. united by al blk. bar. $($ hi.-Brn.).]

Obs.-A question has been raised as to the specitie difference between $P$. .t pollo and $P$. Delins, and the observations of 1)r. Chapman on the larre hardly scen to have been conchsive. There are not very many places where the 2 forms overlap in any tumbres, and when this is the case hybrids are oecasionally, though v. ravely, found, e.y., between Simplon Village and the Hospiee (''hrist); Albula Hospiar, a ? viii. 81 (Fry); others are aloo mentioned by frey in the "Bulletin de lat Soeciétr Entomologigue Suisme," vol. vii., p. "2.tt. Naturally these are in the highest haunts of $l^{\prime}$. Apollo. The probability would seem to be that we have here it sp. almost, but not quite fully evolsed; or rather, separaterd in most loes. but not entirely so in those places wh. are suitablo to both forms. It would seen from the rarity of thase lybrids, that even where they oceur they are less successful in passing through the earlier stages than the progeny of either form alone. That they are true hyrids and not merely intermediate forms is to be inferred from the fact that they occur only when the two lorms overlap. 


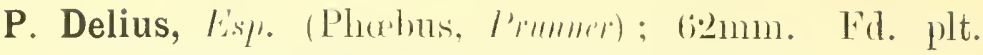
Sarifra!ga alizäles and sempreviemm montanmm.

o with fewer and shorter hairs on body than $\delta$; abdominal sac bin. and horny.

Dist. Char. grol. col. up.s. cream! wh. : antenne annulated : gen. at least one led costal spot up.s. f.w.

Loc. Not rare, but local; found esp. by the side of Alpine streams. Not in the plains nor on the fura, also wanting in the linghests Alpine locs.: gen. from toooft. to soooft.; vii.-riii. On the heights of Glarus and st. Gall (Fin): Larpan, vii. 80; Prätigat, vii. \&। (Thtt); Pont de Nant, vii. 132.2 (1;l.); between the Diablerets and the Argentine, vii. $02(1 /(x)$; all the lateral valleys to the left of the Fibone between Brig and Martigny; e./., Erolema, rii. 11,98 (Flem!n!!); Col Torrent, viii. b. 99 (Thtt); Col des Vaches, Zinal, viii. 19s, ab. on marshy grd. (F.-Brn.); above 5th Refuge on Simplon Road, vii. 9 and 1201 , ab. ( $1 \%$.); also the Gemmi (Far); Oberalp See viii. e. 95 ( $(\%)$.); Andermatt, vii. 111. 86 (.Juns); gen. in the valleys of the Engadine; $\% \% .$, Pontresina, vii. ss, \&e. (Lmn.); Guarta, vii. 22-31, 1900 ; upper

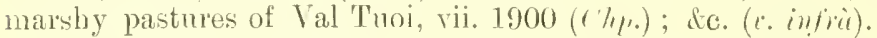

Chamonix; Mt. Cenis (Kam); slopes of Mer de Gilace, Lavancher', viii. 1n. 02; Le Lautaret, viii. 596 ; Larche, viii. b. 1900; Abries, viii. 11. 1900 (Tut) ; above V'inatio, vi. e. 92 (Norris); Petit St. Bernard-La Thuile, riii. b. 9s; Cogne, viii. m. 94 (T'utt); Madone des Fenêtres, ri. 2s-rii. 799 (Lany); Campiglio, vii. (9) $(1, m n$.$) ; Steltio (F, r e y)$.

Directions of Var. (a.) size of blk. and red spots.

(b.) spots f.w. joined together, constituting :

ab. \& Herrichii, ()th.

(c). 'ye-spots h.w. joined by blk. streak constituting;

ab. o Cardinal, ()th.: in wh. the eye-spots are also r. large.

(d.) absence of wh. pupils to red spots.

(e.) occasional entire absence of red from f.w.

ab. Inornata, $11 \%$.

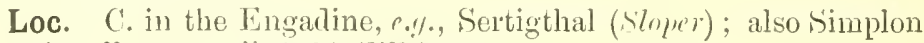

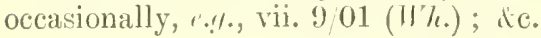

(f.) occasional absence of red from one or both spots h.w.

ab. Leonhardi, linhl: wh. has h.w. only slightly marked.

Loc. Upper Engadine (liihl); not rare in Gadmenthal ( $/$ lirist); Simplon (liit:ier).

(g.) increase in number of red spots culminating in :

ab. I Hardwickii, Kame (Rubra, ('mrist); wh. has three on outel' costal bloteh up.s. f.w. and distinet wh. ante-1nalleg. band, h.w. 


Loc. Esp. Simplon and the Ciennni (F'ar.); Pont de Nint, vii. 13 (lil.).

(h.) decrease of col. in red spots, culminating in :

ab. Aurantiaca, spmen: in wh. they are replaced ly yell.

Loc. Simplon and Gadmenthal (c/rist).

(i.) darkening of up.s. in $f$, culminating in:

ab. \& Nigrescens, $\mathbb{2} \%$. wh. is greatly darker than type.

Loc. Lisp. Engardine, e.\%, Langrard Alp, nr. Glacier"; nr. last trees l. of ft. of Rosegry Glacier, vii. 10 01; Henthal, viii., 1.401 (F'is.) ; Sertigthal, vii., 22 and 25, 1900 (slopere); nr. top of Furka, vii. $19+\left(h_{0}-b n_{*}\right)$.

P. Mnemosyne, L..: 60mmin. Fid. plt. rimglulis antu and c. halleri.

o with smooth shing body; abdominal sac wh., large, and irregular in shape.

Dist. Char. absence of red spots.

Loc. Moist grassy places at moderate heights throughout the region, exc. the .lura; rarely much under :3000ft. or above 5500ft.; vi.-vij. b. ; its lowest loc. appears to be on the mins. round Wallenstadt, at about 1500ft.; occasionally at ft. of cliffs at Martigny $(F a r ., S h n r, W \%$. In nearly all the side valleys from Vernayaz to lirig: Salvan; Forclaz; 'Trient; entrance to the Val d' Hérens; Mayens de Sion; Arolla; Nione; Plaine de la Marteleme; Chandoln; Siasthal; Alpe Foliette mr. Loiche-les-bains; Baltschieder Valley ( $\left.F^{\prime} u r.\right)$; Bérisal, r. ab., vii. b. 98: over before vi. e. 9! : and worn, vii. 1).01, but v. fine on the Steinenalp, vii.

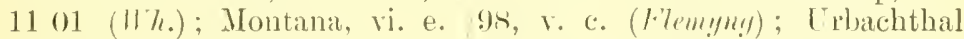
(1/.-1\%); Gadnenthal, at about boooft. (Riritier); Weissenburg, helind the ruins $\left(1 l_{1 .)}\right)$; Engelherg, on Lingsten Alp and in Suren(nthal (.1/issner): Wasen below (iöschenen (Ischl.); Wegrithal (F'rey); above Einsiedeln, at ft. of Mythen (I'cul); Wiesen (Vissuriutl); Val Tellina (1/.-T).).

Digne, vi. 90 (Lmm.) ; ('ertosia di Pesio, v. ah). up to Toooft., vi. vii. 92 (Aorris) : Susa, vi. 2399 (li.-lim.) ; Lölling, vii. 97 (l.mu.).

Directions of Var. (i.) size: specimens from Switzerland and the liasses Alpes are gen. smaller than those from further E., but those from the Steinenalp are $r$ fine.

(b.) size of blk. spots.

(c.) darkening of grd. col. esp. in $f$, culminating in :

ab. \& Melaina, Honith (IIartmanni, Stundtuss).

(1.) broadening of semi-transparent mary., culminating in :

ab. Nubilosa, ('hristuhl : in wh. the r. lroad mary. contains wh. spots.

(e.) absence of blk. spot outside disc. cell, h.w. 
Tribe Aporind.

\section{Fam. PIERID $\&$.}

Genus, Aporia, $/ 1 /$.

Prevailing col. wh.

A. Cratægi, I. : (jommu. Fill. plt. hawthorn, fronit trees.

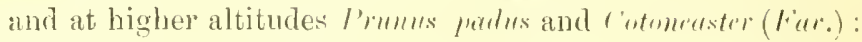
hyb. l.

of with cl. area f.w. ahmost trunsparent.

Dist. Char. Nervares of all ws. strongly marked in hik., lrowner in $q$.

Loc. Widely distributert and gen. ab. over the whole district; in the Alps up to 6000ft. or nore: v., vi., vii., viii. according to altitude, r. . liex, r. l. 97; Nartigny, vi. 102 : Bixisal, vii. b. (01 (Hh.); Zimal, vii. 31 9s: Rochers de Nave, viii. $196, r$. fine and fresh: Ferpècle, viii. 14/96 (li.-lim.).

Directions of Var. (a.) increase of lilk. 1uarkings.

ab. Suffusa, T'utt: with hlk. sutfiusion on out. marg. forming triangular patches.

ab. Marginata, T'utt: further increased to form broad ak. border (v. rare).

ab. Lunulata, T'utt: with a marked thickening of disc. lunule h.w. (b.) col. u11.s.

ab. Melaina, T'utt: un.s. h.w. with a thick dusting of blk. scales between the nervures.

ab. F Flava, Thtt: Int.s. h.w. yell.; not uncommon in fresh (esp. bred) specinems.

Obs.- The all. Alepica, Cosmorici, "'grey, transparent, completely without scales,"I think we can all make with judiciously rough landling; it is doubtless not uncommon in nature towards the end of the season. J

Tribe Pienid, hyb. 1.

Genus, Pieris, Sillimt:

Prevailing col. wh., apex f.w. more or less blk.

Dist. Char. un.s. h.w. without markings, or only along the nervires.

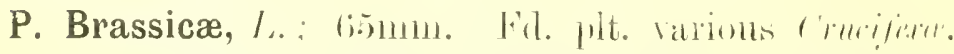
3 without, f with, blk. spots, np.s. f.».

Dist. Char. large size, withont markings ma.s. l.w.

Loc. Everywhere in the plains and up to frooft., in 2 broods, ir.-vi., and vii.-viii.; above that height one brood only, vii.-viii. My earliest date is Veytaux, ir. 599. The greatest heights I find recorded are Riffelberg, sthoft. and Fnorcla di surlej, 905sft. 


Directions of Yar. (a.) size : $50-70 \mathrm{~mm}$.

(b.) v. light apex up.s. f.w. in 1st hroor, known as:

var. Chariclea, stplı.: which has also mu.s. h.w. deeper in grid. col, and powdered, often thickly, with ak. scales ; my most markerl examples are from Martigny.

(c.) a spot on f.w. $11 p$.s. in 3 .

ab. Nigronotata, J(trin)tun.

P. Rapæ, l.. : 45mm. Fll. plt. (rmetere, also mignonette and othel low plants.

o with blk. dash (in addition to the spots), inn. marg. wp.s. f.w.

Dist. Char. small size, withont markings un.s. h.w.

Loc. C. everywhere, from iii. e. to ix. e. in the plains, emergence taking place later as altitude increases, and only one brood being found in the mtns. Occasionally met with even up to the suowline (F'll) ; my earliest date is Veytanx, iii. 15 9!)

Directions of Yar. (a.) size: $37 m m$. $58 \mathrm{smm}$.; the smallest are known as:

ab. Minor, l'sta: : $37 \mathrm{~mm} .-39 \mathrm{~mm}$.

(b.) It. ape up.s. f.w. in spring brood:

var. Metra, stph. (Similis, Lmulikntiskii : Debilis, Alphimaliy) : with spots also It.

ab. Leucotera, Stefanmlli: apex without blk., the spots small and $\mathrm{gr}$.

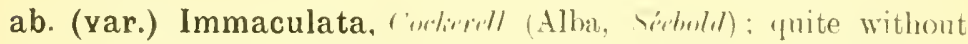
markings.

(c.) increase of size of blk. spots. culminating in :

yar. Messanensis, \%ll. : a summer form. (The smmuel hrood at Martigny is $\mathrm{v}$. (lose to this.)

(1.) un.s. h.w. dull yell. with blk. powdering.

ab. (yar.) Mannii, Mayn' : mn.s. with blk. spots showing througb, apex lighter yell.

Obs.--This is described as at summer form, vi.-vii., hut 1 hatve taken it at Vernayaz, iv. 3002,8 ; and sierre, $v .7 / 02$. 8.

(e.) deeper sharle of yell.in $q$, culminating in:

ab. \& Noyangliæ, semder': a closely approximating form ocenrs in Swit\%, ".!., Sépey, r. 2602 : Martigny, vi.:302 (Fi.i.).

P. Napi, 1.. : tommm. Fd. plt. C'ardamime prutrusis and other low plants, esp. c'rucifer".

o with not more than 1 , $q$ with 2 or 3 th. epots mp.s. f.w, 
Dist. Char. un.s. h.w. nervures broadly suffused with greyish-grn.

Loc. C. everywhere in the plains and alps, and in var. Binonim up to the snow-line, iii. e.-ix.e.

Directions of Yar. (a.) darkening of the gr. tips and spots up.s. in 2nd brood, linown as :

var. Sabellicæ, stph. : $\delta$ has a spot up.s. f.w. ; nerrures un.s. much less strongly marked.

(b.) tendency in 2nd brood to obsolescence of narkings m.s. L.w., culminating in :

ab. Napææ, Ksp. : in wh. they do not extend beyond centre of wing, and in extreme cases are represented only by dots at end of rays on out. marg. : gen. larger than type.

Loc. Oceasionally in many places viii.-ix., e./., Veytanx, ix., e. $98\left(1 \%^{7}.\right)$; Martigny; Sion; Sierre; de. (Fav.).

Abriès, ab., viii. m. 1900 (T’tt); St. Martin Vésubie; Cascade de Boréon (Brm.).

(c.) tendency in $q$ to darken up.s. at high elevations, culminating in :

var. $q$ Bryoniæ, Och.; in wh. all the nervures are broadly suffused with dk. scales, wh. sometimes extend over the whole wiug, wri. col. varies from lt. gr. to yell.

Loc. Gen. replaces type above 5000ft., vi.-vii., 1 brood only, but also found considerably lower. I:. Vaudois Alps, c., .. Rochers de Naye, vi. b. 01, ab., yell. grd. (W\%.); all the alps on S. side of Rhone Valley trom Martigny to Simplon (Far.); ^./., Bérisal, vii. m./98. (n). gro. (II\%.); Riffelalp, vii. 01 (Lmm.); not c. in Bernese Oberlanel (kan'); Gemmi, rare; but Loèche-les-bains, c. (F'lte) : Mürren, viii. b. 1900 (IT/.); Weissenburg (H/.); Trübsee Alp ( 3000ft; (ilarus. ".!., Pantenlorncke, vi. 2602 (k'is.); Maloja, vi. e. 95, v. fresh (Miss Ftn.), ide., de.

Piermont; Savoie; liasses Alps; e.!., Faillefeu, Larche, Corlessart, de. (Kam'); St. Martin Vésubie: Cascale de Boréon (lim.): 'Trafoi, vii. 15, 1900, nearly over (li.-lirn.); Mentelpass, vii. a. 9.) ('l'utt) : Heiligenblut. vii. e. $/ 97$ (Lım!.).

(d.) un.s. h.w., grol. col. and markings viry extremely; with us the spring brood is far brighter and more distinctly marked nu.s.

(e.) tendency of grrd. col. to become yell., culminating in :

ab. Sulphurea, schoufln: wh. has all ws. of a clear sulphur col.

Loc. 'The .Jura (Ay.).

Genus, Pontia, Falr.

Prevailing col. wh, with bllis at apex. 


Dist. Char. grn. or greenish on un.s. b.w., not mely alon! the nervile's.

\section{P. Callidice, Fsy. : $43 \mathrm{~mm}$. Hd. plt. alpine ('rucifire.}

o with $r$. little blk, at apex f.w., \& with wh.-spotted blk. border f. and h.w. up.s.

Dist. Char. un.s. h.w. cl. row of arrow-headed prinnrose spots.

Loc. Y. widely distributed above 6000ft., and occasionally lower, $\because \%$, Egrgen, on the simplon, 5250ft, and, most curiously, for several consecutive years on the dyke bordering the Rhone $\mathrm{nr}$. Branson bridge (Fur.). 6500ft. $-8000 \mathrm{ft}$. is the range of its greatest abundance. It flies strongly and rapidly, often over dangerons ground. All the heights between Martigny and the Simplon (F'ar.); e.\%., Arolla, up to viii. $28 / 96$ (li.-lim. $)$; Steinemalp above Bérisal, viii. m. 98, nearly over; vii. e. 99, and vii. 1101 ; also above the 5th Refuge, vii. $) 01$, v. fresh ( $\|^{\prime} /$.) : Riffel alp, vii. 01 (Lmm.); Gornergrat, viii. b. o1 (Sloper), de. Pilatns (Kneche); ab. on the heights of Glarms; the Pernese (Oberland; from the (iemmi to the Rhone Glacier (Kan'); Oberalp, viii. e. $95(r / h$.$) ; c$. in the

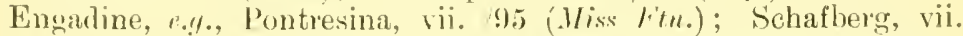
2401, ice. (Fis.); Fusio, vii. 1-12 99: ab. on the Albula Pass, and at the Rernina Hospice, vii. 1900 ( $\left(\right.$ ' $/ h_{1}$.); Had Alvenen, vii.-viii. 8.5 (Limn.); Jura, Mrt. Suchet, 5235ft. (Kane).

Chamonix (hinn'); The Brévent, viii. m. 02; Le Lautaret, viii. b. 96 ; above Abriès, viii. m. 1900 (Tutt); Allos, Larche, vii.viii. (Ponell); Mt. Balne de la Fréma, St. Martin Vúsubie, Madone des Fenêtres, de. (I'rm.): Certosa di Pesio, c. on Monte Faschia and the highest green alps, vii. 92 (Norris); Prenner Pass, smmmit of Postalp, c. (Jomes) ; Stelvio, from Franzenhöhe to summit, vii. 12/01, ab. (Ti.-lirm.) ; Falzarego Pass, viii. u. 95 (Tutt); Nendel, Campiglio, vii. 95: Heiligenblut, vii. 25/97 (Lmn.).

Directions of Yar. (a.) size, esp. in $\&$. My largest specimen, from the Schaflerg, is $48 m+$., my smallest, from the Siteinenalp, $: 37 \mathrm{~mm}$.

(b.) darkness of markings up. and. m1... in $q$.

robs.- Specimens from E. Switz. are gen. finer and better marked than those from the Valais.]

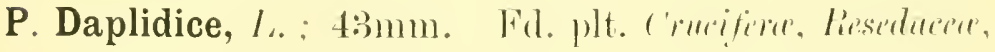
\&c.

of with slight, $q$ with broad wh.-spotted blk. border up.s. f.w.

Dist. Char. un.s. h.w. with much grm.; a more or less circular wh. spot in middle of basal gr'm. patch.

Loc. Not gren. distributed in Switz. and rarely ab. From the lake of Genera to Martigny, but never in any numbers (./ones); on the railway banks at Sierre, vii.-viii. 97, c.; a few $11 \mathrm{r}$. IBírial, viii. 97; Follaterre, ix. 802 ; ab. mp. Staken, vi. m. 92 (11\%.): Simplon. vii. e. 799 (Twtt); rather ab. on ('hippis road nu. Sierre, vii. 29/98; Loèche-les-bains. viii. 27 94; Lugano, iv. 2 96, fine

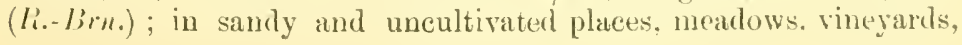


and lncerne-fields, from Martigny to lirig, not rare, iv.-v. and vii.viii. ( $\left(a t^{\circ}\right)$; Lake of Yenchatel (Sumll); St. Gall (Tïschlor) :

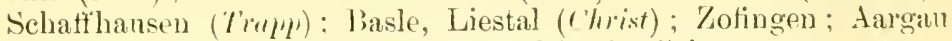
(IIschl.); according to liry not found in the Grisons.

(irésy-smr-Aix, vii. e. 97; viii. m. 1!)00; Bomrós. Manrice, viii. b. 98: Abries, viii. 1m. 1900 (Thtt) ; 1)igne, is. 602 ; ri. 599 (li.-lim.); vii. 91 (L,mm.): Vallon Obsenr; St. Martin Vésubie; zigzags ascending Mt. bialme de la Fréma (I mm.); Prés. St. Didier, viii. 31. 98; Aosta, viii. 11. 94; Susa, viii. 11. 97; 'Torte Pellice, vii. e. 01 ('tutt) ; Certosa di I'esio, in lower valley, vi. 92 (Noris).

Directions of Yar. (a.) size: a small form about 33mm., gren., but not exclusively, in the spring brood, constitutes:

yar. and ab. Bellidice, $1 \%$. (Belemida, $/ / 6$.) ; having un.s. much darker and duller grn., and disc. spot um.s. f.w. sometimes gr. instead of grm.

Loc. Occasionally with type, e.!., Sion, iv, 7 (Bl.) ; Lavey, v. 1602 ; La Bâtias, viii. e. 1900 ( $1 \%$. ) : from Martigny to Loèche (rar.). Alpes Maritimes (as above) (lim.). Cannes, ii. e. 97 ; iv. b. 03 ; Alassio, iv. b. 08 ('Tutt).

Tribe Anthocharid, hyb. p.

Genus, Anthocharis, Bisdo.

Preyailing col. wh. with blk. on f.w. only; grn. on un.s. h.w.

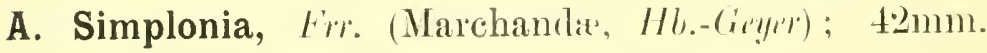
Fil. plt. c'ruciferu.

o larger and more strongly marked with blk. than $\delta$.

Dist. Char. lise. spot f.w. up. and un.s. crescentic or angulated with the hollow towards apex (the edge turned towards base, gen. nearly straight in $q$ ). Differs from lielia by its greater size and absence of silver un.s. h.w. and from var. Ausonia by lyeing more heavily shaded with blk., esp. at w. bases up.s., and by having the much more regular wh. spots at edge of h.w. im.s. elongated.

Loc. Nr. Trient Glacier ; Allée Blanche in Val Ferret; Grand St. liernard; Nionc: Vissoie; Chandolin: Loèche-les-bains; Visperterbinen; Simplon Hospice; Layninthal, fc., vi. e., vii.

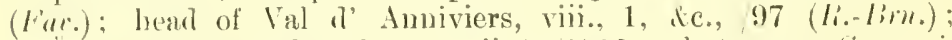
Arolla, path to l'as des ('hêves, vii. 141900, c. but worn; Saas, vi. 2194 ; vil. 2 and 1498 , c. but worn (lim.); Nicholaithal, vi. m., e. lont woln; \%muthal, vii. m. v. fine (./oms) ; Täsch : Stallen, vii. 99 (lima); Riftelalp, vii. $7 / 01$ (l.mm.); Bérisal, vii.e. $9 \mathrm{~s}$ (I\%.); Pont le Nant, rii. 10 (/ll.); nl. Gryon, vii. 02 (Moss): Sefinenthal, viii. 1, 1900 (Fis.) ; 1, v. worn, reported from Campfer, ix. 26 (.Jumes).

Chamonix; Larche (Far.); St. Martin Vésubie, \&c. (lirm.); ('ourmayeur, vii. e. 94 (Tutt); Mt. Chétif, vii. 3,02 (Loup) ; Certosa di Pesio, vi. 15, de. (Norrix). 


Directions of Yar. (a.) marking of nuls. less heavy and of yellower-grn.

Ivar. Flavidior. IT. (Ausonial. l'ar); the form of the plain, gren. with brt. yell, nervmes (hitherto confused with Ausmia): gen. also slightly larger, reaching $461 \mathrm{~mm}$. : o with more or less of tull yell. sutfusion up.s. h.w.

Loc. The Rhone Valley, e.!.. Latrey, г.e. 97: 1. 27 02: Sierre, $\therefore 702(1 \%$ ) ; c. some years between (harpigny and liex, iv. e.;

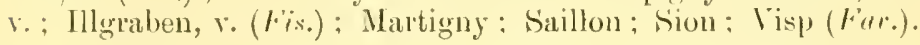

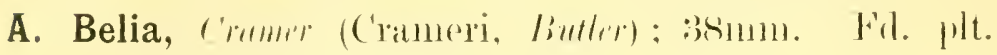
limedratrum and other crucitire.

o im.s. h.w. yellower grn. than o (hime).

Dist. Char. (type) un.s. h.w. mottled grn. and silver ( $r$. Ta!jis var. Bellesina).

Loc. Monte Jiré, iii.-iv. (Kame).

Digne, iv: 602 (li.-lim.); Susal, vi. 1802 (Lurt); Mt. Vinuigrier: Vallon Obscur: St. Nartiu Vésubie (Brm.); La Boccu, Cannes, vii. m. 91 (Nirholsmu); C'ertosa di Pesio, vi. 111. 92 (Nimris).

Directions of Var. (a.) alosence of silver in 2nd brood.

yar. Ausonia, $1 / 1 \%$. rather larger than type; differs from rimilonia (ฯ. ๖.) by having straight or nearly straight onter edge to disc. spot, up.s. f.w., and much less blk. marking esp. at w.-bases and on costa; m.s. h.w. wh. spots at border rounded and much more irregular.

Cobs. The alsence of blk. from the costat f.w., np.s., is not a trustworthy char.; most of the Spanish specimens I have seen have a good deal: spuler figmes atusmia with blk. on costa.

vi.-vii. The 2 broods sometimes overlap.

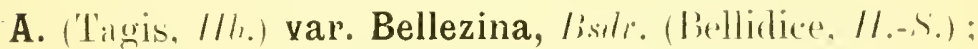

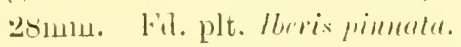

o un.s. h.w. lightly washed with yell. (kich').

Dist. Char. uns.s. h.W. a r. small round blk, dise. spot; anrl wh. spots edged with yell.

Note. The exannation of a large number of specimens from the Valuis. and a comparison of them will specimens of lusmin from s. France. Span, l'iedmont and the Caticasus, has convineed me of what I have long suspeeted, ris., that Ausenia is not found in the Valais. It is also pima dacie improballe that if we have one brood of lielia, it honld take the form of the 2mol. as the same indluences are bronglit to hear on the lave and pune of on insert as on the lot, but not on

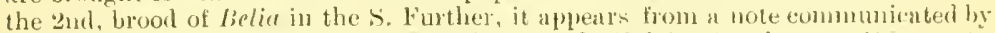

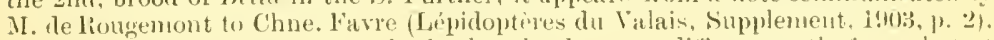
that the 1 . of Simplomia, of wh. he has lned many, differ' greatly from that of Lirlia, and closely reambles that of I'. Doplidire: he describen the p., wh. has no movable segments, as being also leso slender than that of belu, and having a shorter and stuter mome-horn. I have, therefore, followed 1)r. spmler in trealing Simplonia as a separate sp. Mr. Hloper (no denht amongrst many others) has bred

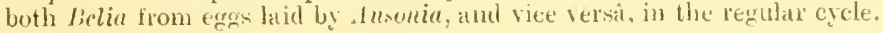


Loc. Digne, on the llombes, vi. $/ 69$, nearly over (Mrs. Nicholl); sparingly at about $3000 \mathrm{ft}$. iv. e. $/ 97$ ('int).

\section{Genus, Euchloë, Hl.}

Prevailing col. wh. or pale yell.; un.s. h.w. with greenish mabling.

Dist. Char. \& with anes f.w. or.

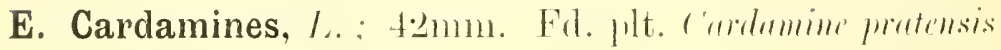
and other crucifirn.

Wh.: $\delta$ with, $q$ withont broal or. apical blotch f.w.

Dist. Char. m.... h.w. marbling of small irtegular dashes extending over whole w.

Loc. (imn. c. in lowlamis anıl smbalpine region, iii. e.-vi. b., and

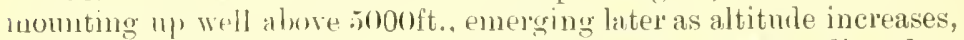
heimg fomm as late as viii. h. in the highest locs. My earliest date is Vestans, iii. 17 !!), the latent I have found recoreled is Zinal, viii. $298($ li.-lim.).

Directions of Yar. (a.) size: vales greatly, commonly ä7mm. 15 mm., exceptionally, $311111 .-4 ! 1 \mathrm{~mm}$.

(1.) si\% of disc. spot f.w. : its rariation culminates in:

ab. Lasthenia, Millire: in wh. all blk. is absent: 12n.s. h.w. with v. pale greenish-yell. markings.

\section{(c.) dimination of or.tip, conlminating in:}

ab. Turritis, ths. : in wh. it only just reaches disc. spot.

Obs. The r. small specimens of this ah, are called ab. Minor, cowerell, and ab. Hesperidis, Nenuhm. and are considered by the lat ter to be a separate sp.

(1.) 3 , m.s. f.w. sometimes with yell. grd. col. exc. inn. mang.

ab. Citronea, $11 \%$.

Loc. Rhone Valley, ic.: ".y., Aigle, r. b. $0: 3$ (Yloper); above Stalden, r. $16 / 08$ ( $11 \%$.).

(e.) $?$, sometimes a dull buff suffusion up.s. h.w., esp. ne. costat.

[Obs. - In the Geneva Nuseum is a hermaphrodite, the body apparemlly of, the ws. more like the of, lat with the lower half of tip of left w. or., and an or. streak on tip of right $w_{\text {. }}$; the rest of the tips show or. through the wh.

E. Euphenoides, Stgr. (Eupheno, lisp.: C'allemphenial,

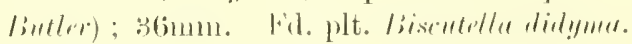

o with primrose-yell., $q$ with wh. gred. col. (and a little or. 111. арех).

Dist. Char. Slight extent of marbling mos. h.w.

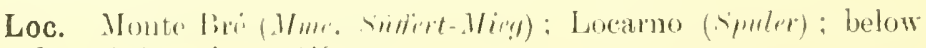
condo (thrist); iv.-r. (hath'). 




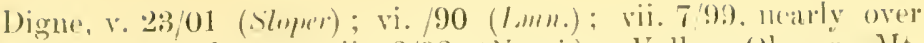
(li.-limo): Bareelonette, vii. $2 / 92$ (Jirris): Vallon Obserr, Mt. Vinaigrier, Grorge de St. André, Canmes (Rrm.): Nice: St. Martin

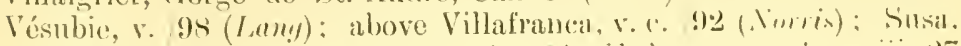
vi. 2399 , still quite fresh (li.-lim.). At Hyides as daly as iii. 27 102 (stoper).]

Directions of Yar. (a.) size (Alpine specimens lariger thin nr. (coast, lim.).

Tribe LkPTosini.

Genus, Leptosia, Hh. (Leucophasia, Stph.: Leptidia. Billbery); byh. p.

Prevailing col. wh.

Dist. Char. Fistreme tenuity of ablomen.

L. Sinapis, I.: :Somm. Hel. plt. Lotus imminulatus, Lathyrus matemsis, Mrobms, Ficia. itc.

o with rounder ws. and less blk. at apes than of.

Dist. Char. absence of grn. tint np.s. h.w. (r. /lupomheli).

Loc. (ien. distributed throughout the region, in the lowlands, iii. e.-vi., and vii. m.-ix., and up to 5000ft. or more in one brood, resembling the spring brood of lower levels, r. e.-vii. 11.

Directions of Var. (a.) loss of markings.

yar. Diniensis, Bste. : v. dk. bloteh on apes f.w. "p.s. but no markings un.s., exc. that the apical blotch shows through, and there is often a $r$. slight cl. gr. band on h.w.

ab. \& Erysimi, lirh.: quite wh. up. and un.s.

rObs.-These are both gen. lowland forms of the summer brood, but Enysimi, at any rate, sometimes occurs in the spring. Ininiensis is the usual form of the summer brood: Erysimi is by no means uncommon, $t . g$. . Aigle, viii.-ix.]

(b.) col. of $111 \mathrm{~s} . \mathrm{s}$. h.w. (the type has gr. markings on yellowish-wh. grd. col.).

ab. Lathyri, Hb. : gr. markings on dull greenish grel., only a long basal streak, and sometimes another beyond it to out. marg. remaining wh.; rather small.

Loc. A spring form, c. in some years in Vaud, the Valais, and elsewhere ( $\% \%$, Veytaux, Y. $/ 99$, where in other years not one is to be found). A b. iv. 03, Aigle (slopero); ('barpigny (Fis.).

ab. Sartha, Jikhl: with brt. yell. grel. col. h.w. and apex f.w. un.s. (a large form).

ab. Subgrisea, st!fr. ; no yell. or gru. in grut. col. wh. is almost covered by the gr. markings.

[Obs.-In the Genera Musenm is a curious specimen deeply smoked in an angular shape at base, with a whitish line of the same shape nr. malg. of the ik. suffusion.] 


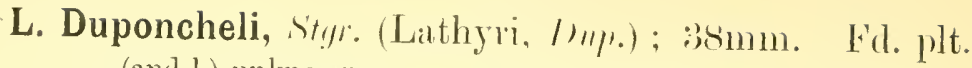
(and l.) unknown.

\& somewhat larger than $\delta$.

Dist. Char. up.s. h.w. with greenish tinge, f.w. with deeper blk. apex than sinapis; large wh. patch un.s. h.w.

Loc. I. local. Wigne, v. 20 02, going over ; vi. b. 99 (R.-lim.) ; vii. 91 (presumably 2nd lorom) (I.mm.); behind Beaulien up to about 1500 it., v. 10(.Jnus) : 1)raguignan, ab. (liaime).

Directions of Yar. (a.) loss of markings.

var. Estiva, Ntır.: with yellowish $11 \mathrm{n.s.;}$ the summer brood.

Loc. ‘.., St. Martin V'subie; c. all romel Digne, rii. 19-29 91 (Nirlmlsm).

Tribe Rimuocernur.

Dist. Char. Short lerd antenum.

Genus, Colias, luth : hyl. l.

Prevailing col. yell. or or, with blk. border.

C. Phicomone, limp. : tomm11. Fid. pilt. spe of licill.

o lather lt. yell., \& whitish with yell. tint.

Dist. Char. err. suffusion on f. and ls.w.

Loc. I. gen, distributed and often ab. on the Bernese, landois, and lalaisian Alps, from $4000 \mathrm{ft}$ to soooft., and fomd both higher and lower. Its lowest loc. appears to be (Oherstalden, $2240 \mathrm{ft}$. (Finy). Sho fal as my experience goes, it ascemm higher than l'ulwu, though it also descends much lower. Above Sépey, about $1000 \mathrm{ft}$. vii. 1997 (11\%); ft. of Argentine, vii. 02 ( $1 / \mathrm{m} / \mathrm{ss})$; lerpecle viii. 1496; Arollat, viii. 2196 ; but totally absent from Kinal, viii. ls (li.-lim.) : Simplon lass, bth Refuge, vab. vii.m.viii. 1n. 98; Steinenalp, vii. e. 99); Mirmen, viii. b. $1900(\mathrm{~W} \%$.) ; Weissenlmerg, al. at about 2650ft. (/l!.); Oberalp, viii. e. 95; (ruarta, vii. $22-31,1900$; Fusio, vit. $1-1299(1 / \%)$; ab. in the

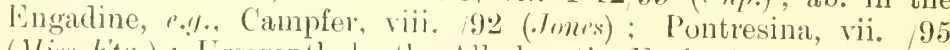
(Miss /tu.) ; Irserenthal ; the Albulat the Furka (Kanc), ice.

In the Jura, Mt. d' Or, and Mt. Suchet; Le Lantaret, vii. e. 96 ; Lawche, vii. e. 1900 ; just above Abries and higher, viji. 11. 1900 (T'utt); c. throughout the Jiasses Alps, Saroie, and P'iedmont (Kame): Alpes Maritimes (lim.); Mont de la baxe, viii. b. 94: Cogne, viii. 11. 91; Au Pra, viii. 1n. 01 (T'utt) ; gen. ristributed in the Tyrol, r.\%, Brenner, v. large, vii. 271900 (li.-lim.); Val Bigontima, viii. 11. 95; Falzarego Pass, viii. m. 95 (Tutt); Campiglio, vii. 95; Iunsbruck, viii. 197 ; also Heiligrenblut, vii. e. 97 (l,mil.).

Directions of Yar. (a.) extent of gr. suffusion.

(b.) depth of gril. col. $\delta$ and $q$.

Obs.-Mr. Fison bas taken a beautiful and interesting hybrid Palonox

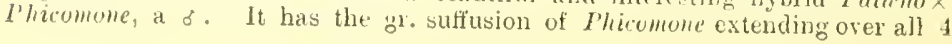




Ws., exc, the cl. half of imm. marg. f.w., on the grd. col, of Palono. It lats also the border of the latter, but the fringe of Phicomme, and the disc. spot l.w., though larger than in Palemo, is only ontlined somewhat thickly in blk. ; that of the h.w. is between the $2 \mathrm{sp}$. in col. and size. The un..s. has inore the col. of Phicomons and the markings of l'aleno, but with borler f.w. nearly invisible.

C. Palæno, I.. (Philomene, /ll.; Lapponical, Slygr.:

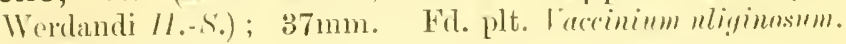
3 lort. daffodil yell., \& nearly wh.

Dist. Char. Extreme smallness of dise. spot, ontlined in blk. f.w., pale yell. h.w.

Obs. Great confusion exists in the nomenclature and the descriptions of the vars. of this sp., and though I have anleavonsed to clorr it up, 1 am by no menns cellatin of the justiot of iny conchusions. F'irst then, in some authors Europomene, (rhs., is treaterl as being the same nume (though applied to an opposite form of var.), as Eimopome, Fisp.; then the smuller forn of the Swiss

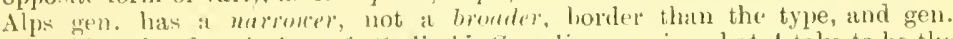
resembles the description of caflischi, Carmlju. exc. in what I take to be the specinl distinction of the latter, riz., the absence of the discoidal spot up.s. f.w.; then anain. the majority of the Swiss specinens appear to be ilentical with those of $\mathrm{N}$. Europe, as stated by lirey and firre, though contradicted by Staudinger, whilst the latge N. (ierman form, Furopome, Esp., is not found with us. I am inclined to suppose that we must disregard the narrower border (so far as named forms are concerned) and inchule these specimens for the present in the type, as they are not at all yellower than otbers, and so can hardly come under the form schildei, Styr.

Loc. Confined to high elevations, from $3000 \mathrm{ft}$. to nearly $8000 \mathrm{ft}$. but more usmally from $5000 \mathrm{ft}$. to $7000 \mathrm{ft}$. Fr", however, remarks that single specimens are occasionally taken in the lowlands; (possibly these may be bred); vii.-viii. On most of the heights from Martigny and the Gemmi to the Stelvio, and on throngh the Tyrol, de. : P.\%., Arpilles, Borine, C'atogne, and Grand St. Bernard, nr. Martigny; at the top of the Val d'Anniriers; Kemmatt; the (iornergrat; Saras; Hiesch; Mörel; Aletsch rilacier, de. (Far.); Arolla, vii. 11, 1900, worn; towards Evolena, vii. 17, 1900 ; Eggishorn, vii. 1693 ; Belalp, vii., 4, 9!) (likm.) ; Steinenthal; II. end of Stemenalp, vii. 1101 , fresh ; vii. e. 99, worn: top of Simplon Pass, beyond the Hospice, viii. m. 95, worn: vii. m. 99, fresh $(\mathrm{II} \%$.) ; Furka, Andermatt side, viii. 194 (li.-lim.) ; Engelberg ( ( hrist) ; Oberalp, viii. e. 9.) : Davos 1'latz, viii. 2, 1900; Guarda, vii. 22-31, 1900 ; Pontresina, vii. 1-21, 1900 ( / / .) ; Uper Éngadine (Miss litn.), r.l., Morteratsch Gilacier, c. vii. (Nirholson); St. Moritz and IV eissenstein ( $F$ rry); Dischmathal, rii. 12, 1900 (s/oper);

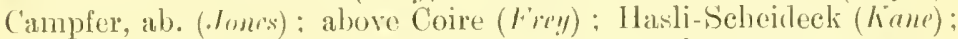

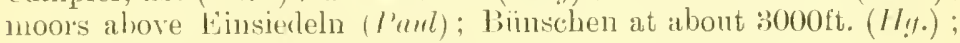
on the Jura at Tramelan ('ruidut).

Chamonix (Fur.); the Montanvers, viii. m. (2) (Tutt); nr. P'ontarlier (hans) ; Le Lantaret, vii. :30-viii. 596. fine bnt searce (T'ntt); Abries viii. m. 1900; Larche, vii., scarce (l'owell); Lac de la Madeleine (fiane); Alpes Maritimes (lim.) ; $\because !$. , St. Martin Vésubie, vii. (l'orell): Mont do la Saxe, vii. e. 91: above Pró St. Didier, viir. m. 98 (T'utt); Brenner, vii. e. 1900, fresh (li.-lim.): Snlden, vii. 1900 ( I mm.).

Directions of Yar. (a.) breadth of border in 6 .

var. (\& ab.) \& Europomene, uch.: with broader border, of smaller size, nn.s. darker. 
Loc. Grimsel; Mayenwand (M.- I).); Gros Glockner.

ab. Flayoradiata, $\Pi$. : with narrower border crossed by yell. nervures.

Loc. e.\%., Steinenalp, vii. $2999(11 \%$; ; \&c.

(b.) col. in $q$.

ab. (\& var.) \& Herrichi, Styr. (Werdandi, H....: Philomene, Dup.) : yell. grd. col. varying from pale lemon to the deepest yell. of $\delta$. In MIr. Fison's collection are ' $q$ s of a beautiful cxeam col., quite different in tint from the usual yell. $q$.

Loc. By far the commonest form on the Siteinenalp, and the only one 1 bare seen on the Simplon; Campfer, ab. (efones); Hortelatsch Glacier, rather $氏$ (Nirholson) ; as an ab. gen. where type is found.

(c.) presence or absence of spots in blk. border of $q$, up.s. f.w.

(il.) grd. col. 1 n. .s. h.w.

(e.) absence of disc. spot up.s. f.w.

ab. Caflischi, c'aradja: described as also having narrower border up.s. and greener h.w. un.s.

(f.) disc. spot f.w. occasionally filled in with blk., up. and un.s.

(g.) disc. spot f.w. un.s. occasionally filled in with or.

C. Hyale, I. (Palieno, tr.sp.); tsmm. Fd. plt. Coronilla rava, licia, and other Lamminesser.

o brt. primrose yell., o clear yellowish wh.

Dist. Char. 13lk. spotterl border, narowing alnost to a point at anal ang. f.w., and v. slight on h.w.; Mistinguished flom l'alimo val. Mrivili by larege blk. Aise. spot f.w.

Loc. Gen. distributed and c., nsually ab., v.-vii. and viii.-xi. nı., occasionally up to soooft. My earliest date is iv. 24/99. The highest loc. in wh. I have seen it in any numbers is above the 5 th Refuge on the Simplon J'ass, at nearly $7000 \mathrm{ft}$.

Directions of Yar. (a.) size : exceptionally from $3511 m$. to $521 m$ m. (b.) depth of grd. col., the brighter and deeper form of $q$ culminating in :

ab. I Inversa, Ilphiraliy; in wh. it is of the col. of the $\delta$.

Obs. -The ab. Flune, IIur. seems to be synonymous with this fas given in Styrs'. ('atalogne, 1!)1), as it is only sometimes that the yell. spots in border of f.w. are developed into a band.

(c.) tendency to disappearance of parts of the blk. border.

ab. Apicata. Tutt: in wh. band f.w. is reduced to an apical tip. ab. Obsoleta, Tutt; in wh. band of h.w. is aluuost lost. 


(d.) tendency to exaggelation of blk. on h.w. amounting occasionally to a double row of blk. spots.

(e.) diminution of double disc. spot b.w.

[ab. Unimaculata, litt: in wh. one is obsolete.

ab. Pallida, I'utt: in wh. it is barely visible.

Obs.- In Col. Agassiz' collection are 2 is, one with the un.s. h.w. entirely, and the other partly It. hluish-grm., the latter irregularly streaked with or.; for this ab., which may recur, is proposed the name:

ab. Viridescens, Sloper.

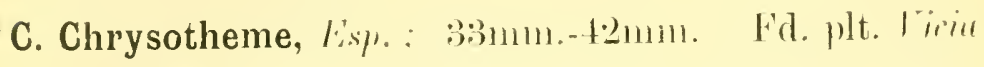
liirsitu.

o without, f with yell. spots in dk. borker.

Dist. Char. f.w. I1).s. yell. costa, in connection with It. dull or. grit. col.

Loc. Sityria and Carinthia; Salshurg. vii.-viii. (Kane); above Mödling, viii. e. 97. c. (Misi F'tu.).

Directions of Yar. (a.) size: (r.suprii).

(b.) up.s. f.w. disc. spot often reddish at out-

line, sometmos ontlined only in blk. and filled in with reddish.

"C. Myrmidone, lisp.; :32nmm.-45mm. Fd. plt. cylisus

biflurus: l'istus.

\& withont, $q$ with yell. spots in blk. lorder.

Dist. Char. f.w. If).s. costa yell. (in z), in comnection with red.or. enrl. col. : distinguished also from tirluse by namower blli. horder and in o by squater yell. spots.

Loc. Sit. P'anl, Lavanthal. vii. 11. 9T (/.mu.); Sityriat (and N. Italy), ir.-1. and vii.-viii. (smuler).

Directions of Yar. (a.) size: (r. suruit).

(b.) grat. col. of $q$.

ab. \& Alba, Styr.: almost wh.; distinguisherl fiom ab. Helice, ats type from lislusa.

Obs. It is not mnlikely that both the abovesp. may have been overlooked in varions locs. as Eiduse, e.g., chrysotheme in N.E. and Myrmidone in S.F. Switz.

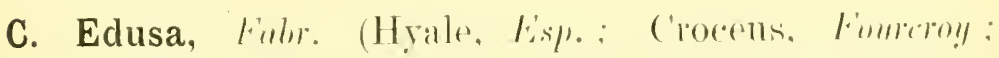

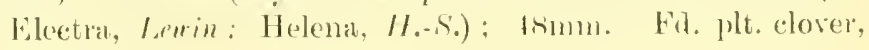
trefoil, ice.

$\delta$ without, $q$ with brt. yell. spots in broud blk. border.

Dist. Char. brt. or. grel. col., deeper than 'hrysothrme, not so red as Myrmideme.

Loc. I. eren. Alistributen in the lowhands and often ab. 11p to to00ft., mich less ab. than /lyale between 1000ft. and 6000ft., but 
mounting oceasionally even above soooft., $\% . \%$, on the Riffelberg. V.-X.

Directions of Yar. (a.) size : exceptionally from $321 \mathrm{~mm}$. to $52 \mathrm{~mm}$. $(A ! \%)$.

(b.) Aiminution of spots in $\&$ culminating in :

ab. Obsoleta, I'ntt: in which they are absent.

[Obs.--Surely one wonld he justified in including under this ah. those $\delta$ s wh. are quite without gell. rays in the border.

(c.) depth of col. of horder.

ab. Brunnea, lint: in wh. the blk. is replaced by lin.

(1.) less depth of grd. col., esp. in $f$.

ab. Helicina, "Wth. (C'brysotheme, stph.: Anbuissoni, 'urarlja): wh. has gred. col. of a paler or.

Obs.- The nume thrysotheme, siph., nust be regarded as a nomen preoccupatum ( $i$ suprii), and tubuissoni, Caradja (Iris, vi., 1893), must fall before Helicina, (),th. (Bulletin de la Societio Française. 1880), mnless the latter is held to represent it further shade between this ab. and ab. Helice, in wh. case f'aradja's name must hold good.

This form occurs in both o and $q$.

ab. $q$ Helice, 1/h. (Enropome, stph.); "pale lemon or creamyyell." ( $T$ 'itt).

Loc. Like other abs. with the type; $r . \%$., Sierre, viii. 18,99 ; Branson, vii. 19, 1900; vii. 8 02 ; Follaterre, vi. 4/02; Aigle, viii. 23, 1900 ( $11 \%$.); Steinenalp, vii. 902 (Shelelm); Weissenburg $(1 / \%)$.

(irésy-sur-Aix, vii. m. 1900 ('Mitt), \&e.

ab. \& Pallida, l'utt: "wh. or creamy-wh." (Tutt).

(e.) size and shape of disc. spots f. and h.w.

Genus, Gonopteryx, Lath (Rhodocera, listle).

Prevailing col. yell.

Dist. Char, a small, sharply angled projection in outline of each $"$.

G. Rhamni, L. ; 5smm. Fil. plt. lihummes cothenticus, li. Frantula: in motns. li. l'mmila: hyb. ims.

d brt. camary yell., \& grreenish wh.

Dist. Char. small or. disc. spot on each w.

Loc C. throngh the whole region exc. the coast of the Alpes Maritiues, axtending in isolated cases to an altiturle of $7500 \mathrm{ft}$ (over soooft. on the Stelvio, li.-lim.) ; according to Fren, in "2 broods, vi. and riii.-ix; other anthorities give only the latter. It is of comse e. in the spring, even at ii. e. and in snch excellent condition that it is difficult (to me almost impossible) to believe that it never hybernates as a pupa: that there is a fresh hrood earlier than viii., antmits, in many places, of no rombt. witness the following lates: \%urch, Lncerne, vii. s5; Nenhansen, vii. s9; \%ermatt, vii. 01 : Mendel 1'ass, vii. 95; baveno, vii, or'; Jigne, vi. 90, vii. 91 $(\mathrm{l}, \mathrm{m}$.$) .$ 


Directions of Yar. (a) tint of un.s. h.w. both in $z$ and $q$.

(b.) "mealiness" of texture up.s. f.w. constituting :

var. Farinosa, st!ll.

Loc. Lac de Indone ( $\left.1, \mathrm{~m}_{\mathrm{m}}\right)$.

G. Cleopatra, l. ; (itmm!. Fil. plt. Pllummus alprima; hyl). im..

o gret. col. brt. yell., \& greenish wh.

Dist. Char. $\delta$ brt. or. suffinsion extending over greater part of f.w. up.s.; \& Distingnished from likamni of by greater size, and slight or. blotels at root of $w$. (? var. of lihammi.)

Loc. Monte Bré (1/me. Süfirt-Mirg) ; below 1selle, and bas been found at Axenstein (heme). ii.-iv. and vi.-viii.

Digne, vi. 90 ; vii. 91 (L.mn.) ; iv. 502 ; vi. !) 99, 1 st and 2 nd broods respectively; St. André, x. $16 / 02$ (It.-lim.); Alpes Maritimes, c., occurs even above Venanson (lirm.); Certosa di P'esio, vii. 92 (Noris).

\section{Fam. NYMPHALIDA.}

Sub.-Fam. NYMPHALINA.

Tribe ARrixidi : hyb. l:

Prevailing col. Tawny or', with blk. spots.

Genus, Dryas, $/ / \%$.

Dist. Char. un.s. h.w. silvery bars.

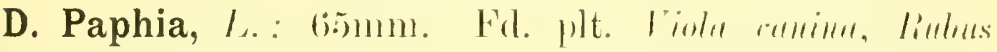
Idtus, \&c.

o darker than $\delta$; $\delta$ show's a conspicnons thickening of 4 lowest nervires f.w.

Dist. Char. un.s. f.w. grrl. col. or. (r. l'antora).

Loc. Everywhere in lower valleys, gen. c., often ab., but seldom reaching much above $3500 \mathrm{ft}$; ; vii.-ix. b. (Wears well. I took an excellent o above Montrenx, ix. 102 ).

Directions of Yar. (it.) col. of metallic glow un.s. h.w., rangingr from pink to prop.

(b.) depth of grm. grrl. col. un.s. h.w.

(c.) depth of gred. col. up.s. $\uparrow$, culminating in:

ab. \& Yalesina, likp.: wh. has grd. col. yellowish brn. mnch suffinserl with blk., giving dk. appearance.

Loc. Sporadic: r. uncommon in N. of region, less scarce in S.,

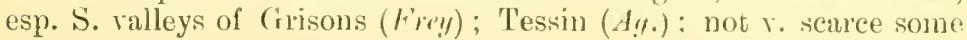
years in the Rhone Valley; ".l., Aigle in 97 (11\%.): Salvan ( $\left./ \%_{\circ}\right)$; 
Visp, viii. b. $/ 98$; Pfyn, vii. e. $/ 99(W h$.$) ; c. one year at Stalden$ (Frey) ; Thusis, vii. 95 (Miss Ftno), \&e.

Lower slopes of the Bróvent, viii. $18 / 02$ ('Tutt); Chamonix, viii. $/ 93$; above Varenna (Wiss litn.); Baveno, vii. 88 (Lum.); Alpes Maritimes ( $\mathrm{B} r \mathrm{~m}$.$) ; Pré St. Didier, viii. m. /98; 'Torre Pellice$ and Bobbie, c., vii. m. 01 (T'itt).

(a.) absence of silver un.s., constituting:

"ab. Immaculata, billir. (Anargyla, stur.); wh. occurs rarely in the Alpes Maritimes ( $\mathrm{k} ; \mathrm{m}$. .).

D. Pandora, Shitï. (Cynara, Fulu.; Maia. Comer); $75 \mathrm{~mm}$. Fa. plt. Viola tricolur.

3 has nervures ir. 1 and 2 up.s. f.w. widened.

Dist. Char. m.s. f.w. large cherry-col, patch.

Loc. V. scarce (and accictental) in Switz. Aigle. vii. 6/97 (Loure); Lausanne, viii. 18/99) (Thutr); Fully (Heissuer); Loèche (Kuecht); Fische (Trapl)); Pfynwald (Patrl); Nioue (Tusker); said to be not meommon at the entrance of the Val Fex, nr. Sils.

Much less scarce S. of the Alps. vi.-ix. b. (sml'y); Val d'Aosta, above St. Rinny, on the St. Rernard route at about $5500 \mathrm{ft}$. (!), vi. 25 (Far.); Cournayenr, vii. 1503 (Lome); Pró St. Didier, viii. b. 94, c.; 98, scarce: Cogne Valley, viii. m. 94; Aosta, viii. m. 94 (Tutt); Roquebilicire. St. Martin Vúsubie, La Bollene, St. Sauvenr, cke., vi. vii. (lim.).

Directions of Yar. (at.) grd. col. up.s.: ranging from dk. ochreons to greenish ochreous.

(b.) dininution of silver m.s., esp. in $\delta$. culminating in :

ab. Paupercula, liumpsa: in wh. there is none.

Genus, Argynnis, lirlir.

Dist. Char. un.s. h.w. large silvery spots.

A. Aglaia, 1.. : 58mm. Fd. plt. varions Fiuluow.

o has a slight thickening of the two lowest nerrures up.s. h.w.. o larger and gen. darker.

Dist. Char. un.s. h.w. brt. yell. ante-margl. band without spots.

Loc. I'. widely distributed and c., esp. on hill-sides, vii.-viii. ; most ab. from $2000 \mathrm{ft}$. to $4000 \mathrm{ft}$., ascending in some cases, e.:., on the Simplon Pass, even above $6000 \mathrm{ft}$.

Directions of Var. (a.) resluction in size, culminating in :

ab. Nana, Wh.: not more than $48 \mathrm{~mm}$.; not bleached like rar.

l'ithate, ylowre, but brt.; \& scarcely darker than 8 .

Loc. Nr. top of Simplon Pass, viii. m. 97, several ( $1 \%$.)

(b.) shade of grd. col. up.s. [This gives rise to many abs., viz. : 


ab. 3 Flavescens, l'utt: lighter and brighter or.

ab. \& Aurea, 'I'utt: pale or.-brn.

ab. \& Pallida, Tutt; lighter still, costa and out. Jurw. pale strawcol. $]$

ab. \& Suffusa, 'T'utt: base, spots and nervures shaded with fuscous; gril. col. at costa and a row of spots at ont. marg. whitish ochreous.

(c.) extent of grn. suffusion un.s. h.w., sometimes nearly covering yell. band.

(d.) basal area of mu.s. h.w. fuscons instearl of ginn.

ab. Fusca, Titt.

[Obs.-A v. remarkable ab. was taken by Rev. A. M. Moss at Villars-surBex, vii. $26 / 0^{\circ}$, and described and firntred in the Ent. Rec., vol. xiv., No. 12, p. 311 ; up.s. ahmost entirely blk., ulso un.s. f.w., the silver mostly replaced by bronze placed in dk. grn. An a b. in Mr. Fison's collection has a band of large blk. blotches, just contained by the branches of the nervures.

A. Adippe, 1. : 58mm. Fd. plt. various violets: hyb. (at any rate, sometines) ov.

3 with nervures iv. 1 and 2 , v. much thickened up.s. f.w.

Dist. Char. mn.s. h.w. deep golden-yell, ante-malgl. hand containing reddish-bru, silver-centred spots.

Loc. Everywhere up to about 4000 t. in and about woods, and often also on slopes and at way-sides, vii.-viii.

Directions of Yar. (a.) size: commonly ömm.-(j5mmn.

(b.) tone of gird. col. ip.s. + .

(c.) Ak. band next to margl. silver spots in.s. b.w.

ab. Yirgata, T'utt: the sharle of brn. varies; one in my collection is deep chocolate ; 1 at Gryon, vii. 02 ( $1 /$ oss $)$.

(d.) diminntion of silver un.s.

ab. Intermedia, Thtt: withont silver at apex f.w. or lorder h.w.

var. Cleodoxa, ()/s: without silver at all, exc. tiny centres of spots in ante-margrl, band.

Loc. The usual form $\mathrm{S}$. of the $\mathrm{Al}$ ss, e.\%, Brusio, vii. 1301 (Fis.); Chiasso, vi. 24, San Stefano, vii. 7 (Maysr).

St. Martin Vésubie, but not c. (I'rm.); Pré St. 1)ielier, viii. ms. gs; Torre Pellice Valley, viii. 01, ab. (T'utt).

A. Niobe, L.: $49 \mathrm{~mm}$. Fd. plt. various spe of violet. o grd. col. Aarker than of, wh. has also the $: 3$ nerwores above the lowest up.s. f.w. r. slightly thickened.

Dist. Char. un.s. h.w. buff ante-margl. baud with r. small redbrn. silver-centred spots; has a rather uashy appearance; is gen. noticeably smaller than dilipe. 
Loc. In the forest zone and above the tree limit up to about 7500 t., vii.-viii., but the type form is not v. c. in Switz. I have only fornd it in any numbers at one point on the Simplon, ri:., in the first open field on the path leading from the 4 th liefuge to Wasen, viii. b. 9s, dc. The type form is specially mentioned for the following locs, but is to be found amongst var. Firis in many others. Niouc, Susillon, Ponchette, Chandolin ant /inal in the Val d'Amniviers; Sierre; Loiche-les-bains; Stalden; Laquinthal (Far.) ; Arolla, viii. m. 99 (Titt) ; St. Nicholas, vii. 13 98; Zermatt, vii. $1099(\mathrm{~h} / \mathrm{m}$.); Saas Fé, ab. (Jones): Weissenburg (Hy.) ; Basle (1/hrist); in the Aargan Jura (Hschl.); Engelherg (Balien); Pontresina, vii. (Miss litu.); Churwalden (//y.).

La Fancille on the Jura, viii. 10 ( $/$;l. $)$; above Lac Bourget, vii. e. 98; Megree, viii. b. 02 : Larche, viii. b. 1900 ; Abriès, viii. m. 1900, v. ab. and brt.: Cogne Valley, viii. m. 94; Coumayeur, viii. b. 94, ab.; above lioblie, viij. m. 01 (Tutt); Mendel Pass, vii. ,95 ( L mmo).

Directions of Var. (a.) tone of grrl. col. up.s. o ; varies greatly, from yell.-lmn. to warm or.-brr. (same range in var. Fris).

(b.) diminntion of silver m.s. culminating in :

var. Eris, Mrifen (Cleodoxa, Ls.s.); $52 \mathrm{~mm}$. in wh. it is replaced by yell.

Loc. Far more c. than type; gen. ab. on the mtns. of the whole region up to $7500 \mathrm{ft}$., vii.-viii.

(c.) increase of $\mathrm{dk}$. suffusion, c. to some extent $j_{i n}$ o , culminating in :

ab. Pelopia, lirlih. (Niobe, //b.); up.s. almost wholly snffinsed with b]k., markings of un.s. sharply drawn in blk.; no silver.

Loc. $1 \delta$ in Steinenthal, nr. Bérisal, vii. 25/99 (11\%.); $1 \mathrm{mr}$. St. Morit\%, vii. /st (Nirholson).

\section{Genus, Issoria, $/ / 1$.}

I. Lathonia, 1.. : t2mmm. Fil. plt. violets. (molirylis. Anchuse oficinalis.

o larerer than o and with rather darker and more extended basal suffusion.

Dist. Char. great size of silver spots m.s. h.w. and concare ont. marg. f.w.

Loc. One of the most widely distributed butterflies of the region : gen. ab. in the plains and lower elevations, and mounting as high as 8500ft. and more; 'r\%., on the St Rernard Patss, the Pierre-i-Toir, and even the Gomergrat, nearly $10000 \mathrm{ft}$. (F'ar.); gen. iv.-vi. and viii..jx. My earliest date in Switz. is iii. 15/9!), but further $\$$ s. it appears much earlier, e.\%, at Camnes, often i. e. (c/\%\%). Often settles on the bare wrounil.

Directions of Yar. (a.) size: the spring brood is small, the later 


incomparably larger and finer; of of the former often not more than 3smm., $\&$ s of the latter sometimes as much as $5010 \mathrm{~m}$.

(b.) confluence of silver spots un.s. h.w.

ab. Yaldensis, kisp.: in wh, the blk. spots mn.s. f.w. are also confluent.

Obs.-I have never seen this ab. nor met with anyone who has, it must, I think, be $r$ sence.

\section{Genus, Brenthis. $/ I l$.}

Dist. Char. m.s. h.w. either prp. or silvery patches or both. [In the case of ll'cat', wh. has neither, the gen. arrangement of un.s. h.w. is such as to connect it nmmistakably with others of the genus, such as selene and $l m o$.j

B. Euphrosyne, I. : 4.2mm. Fd. plt. T'iolı canina, I'. sylratica, Fra!naria, ic.

o gen. rather larger, and deeper or. than $\delta$.

Dist. Char. Brick-red spots and suffusion un.s. h.w.

Loc. (ren. Mistributed and often c. in the lower valleys and slopes, and by no means rare at 5000ft., e.\%., liérisal, and momnting occasionally up to $7000 f$; gen. larger and brjghter at lower elevations ( $\bullet ! ., r$. fine at Lncens, v. 21, 1900, Fis.), and smaller and darker at greater altitudes; r-vi., and viii. at lower, vii.-viii. at higher elevations; fairly large and well-colonred at Ferpècle, viii. m. 99 ('l'utt). My earliest date is Veytaux, iv. 5/99.

Directions of Yar. (a.) exaggeration of blk. spots and suffusion at base of ws.

(b.) tentency to diminution of margl. row of silver spots mu.s. h.w., culminating in :

ab. Obsoleta, Tutt: in wh. there are none.

B. Selene, Sillif. (Emphrosyne, Lirgstr: Euphrasia, larin); 37mm. F(t. plt. riola ranina.

I gen. rather larger and slightly more or. than $\delta$.

Dist. Char. un.s. h.w. dlestnut-brn. spots and suffusion.

Loc. V. local and gen. scarce in Switz, v.-vi. and viii. Where it occurs in the mins., up to nearly b000ft., I feel no doubt there is only one brood, vii.-viii. Basle (hmerht); the Jiechburg (li....); Bimen and solenre (Meissmr); lierme: Bmoglorf; Tuttrigen, Meiringen, and the Oberhaslithal as far as (intamen, and above, ( in the last two locs. (1/.-/).); Gachmenthal, nr. the Steine (ilacier (Frey) ; Rosenlaui, lather worn, vii. 15 90 ('videaur); nr. Lausanue (Lulary) ; on the Curfirsten, and above Amren (Tiischler); Weusen Marsh, vii. ; 01 (F'is.) : Kurich, nt. the Trichterhaus Mill, I. scarce (Supll) ; Weissenburg, c. (Il!.); at the Grangettes, batween lillenene and Bonveret, v. 19, fairly c., os only ; vi. 799, r. ab., $q$ s also : banks of the libone at Bonveret, vi. 1900 and (01; Reverenlaz, 
․ $3003\left(1 \%^{\%} \%\right.$ ) Touvy, Loèche-les-bains, Zematt and Búrisal (lar.): less scalce in the Grisons, e.!., Dischmathal, vi. 27; vii. 201 ; S. sille of Pernina Pass, vii. () 01 (l'is.) ; m. St. Moritz, lut not e. (Xirholson); Sagno, v. 27 ; San Stephano, vi. 10 (1/ay/r); Locarno, iv. m. 0:), c. ('liett): Monte Salvatore, vi. b. (Inmes).

Digne, vi. 90 ; vii. 91 (lım.) ; Torre Pellice, viii. b. 01 (l'utt); woods nl. Trafoi, vii. m. 1900 (li.-lim.) ; Sondrio, viii. 96 (.Miss Ftu.): Campiglio, vii. m. $95\left((') l^{\prime} \cdot\right)$.

Directions of Yar. (a.) size: sometimes 2 nd brood is r. small, constituting :

ab. Selenia, $l \%$.

(b.) depth of grd. col. un.s. h.w. "Alpine examples are lighter, but with ilarker red" (livey).

(c.) silvery spots un.s. h.w. lengthened into streaks.

ab. Rinaldus, IIbst.: leported from Bouveret (Far.).

(d.) darkening of grd. col. up.s.

ab. Thalia, Hb. : darker than type, but without cl. blk. spots; also reported from Bouveret ( 1 'ar.).

[(?) ab. Intermedia, sumugher"y : blackish bın., with margl. row of fulvous spots.

(?) ab. Marphisa, sumbler!! : almost unicolorous blackish.

These being $\mathrm{N}$. abs. can only le expected in the bighest altitudes reached by the sp.]

B. Aphirape, Hl, : $37 \mathrm{~mm}$. Fd. pilt. listort and marsh violet.

$q$ with dull suffusion extending orer half w., but not obliterating the markings.

Dist. Char. un.s. h.w. brond margl. row of lt. yell. angulated spots, followed by a row of small spots as in The, 7)aphne, ifc., gen. silver-centred, but without prep.

Loc. I. local ; in marshy places; mtns. of Carinthia; marshy mtn. mearlows of S. Hrance (liame).

Directions of Yar. (a.) mmount of silver on un.s.; sometimes mone at all, the maximum being silver in cl. and margl. bands, as well as the row of small eye-spots b.w.. and in the centres of the small spots nu. apex f.w.

*B. Hecate, Lisp.: $29 \mathrm{~mm}$. Fil. plt. (and l.) muknown. o larger than of and with greenish-l,k. wing-bases.

Dist. Char. nn.s. h.w. '2 v. conspicuons long, lt., somewhat wedgeshaped spots nr. centre of out. marg., the points being towarts the base. $\quad$ On up.s. a hroid dk. marg. followerl by 2 nearly 


parallel rows of dik. spots, f. and h.w. : col. of un.s. h.w. rusty br'n. and fidled butf:

Loc. Mtns. of Alpes Maritimes, rare (Milliwe); r.\%., 'I'horene, at about $4000 \mathrm{ft}$, vii. (I'mefll) ; Piedmont (hame); mtns. of S. Tyrol

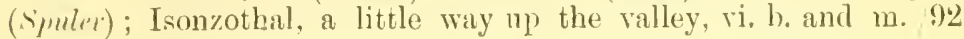
(Norris).

B. Thore, /ll.; 43mm. Fit. plt. (and l.) muknown,

q gen. lighter than of rp.s.

Dist. Char. conspicnous dk. suffusion mp.s. ; differs from Ino var. Yimalensis by the domble band of prp. un.s. h.w., one margl., one (incomplete) more $\mathrm{cl}$.

Loc. Local and gen. scarce in Switz, though c. in a few places; not reaching far W. or' S., found up to about $6000 \mathrm{ft}$, vi.-vii. according to altitude. Surenenthal ; Gadmenthal (Ririt:ev); Rosenlani, the Oberhaslithal, and the Reichenbach, e. (M.I).); Handeck Fall (Sull) : Roussthal, ab. (hame) ; Seealpthal, scarce (I'ryrr-Imhofi); in the bays d'Fulaut, ahove Chatean d' Oex, between Rossinicre and Rougemont, and on towards Simen (M.-/).); in the Grisons, above Flims (c/rist); above Pontresina and Muottas, vii. m. 1!100 (c/h\%); Roseggthal, 2 only, vii. 9), (Miss lin.); in a wood nl. the golge, vii. (Xirhulson) ; nr. Bergïn, scarce ('/ll.); 'Tarasp (hillius); opposite Guarda, 1 only, vii. e. $1900(c / \mu$.$) .$

Trafoi, vii. 15 1900, fine but scarce (li.-lin.) ; the wood sloping down to the Bremmer See, vii. 27, 1900, woru (.lonss); Pejo, vii. 95 ; Lölling, vii. 897 ( / .mm.).

Directions of Yar. (a.) amount of. Ak. suffinsion mp.s.

B. Daphne, Sillifi. (('hloris, lispo): $47 \mathrm{~mm}$. Fil. p)t. limbus illews, li. jimtirosus, ile.

$q$ slightly linger and more strongly marked than $\delta$.

Dist. Char. un.s. h.w. prp. suftusion extends to ont. marg. on lower half of $w$.

Loc. In Switz. gen. foumd only between Lavey and Inder, ¿.!., Lavey, vij. (I:l.) ; between Vermayaz and Martigny under the clifts. vi. 27,1900 ; vi. 1901 and 02 ; also mnder cliff's on opposite side of valley, vii. 9, 1900 ; vi. $2902(11 \%$.) ; between sierre and Lockhe, vi. 2297 (l'ustans); Sion, Niouc, Saillon (f'at.); also reporterl, doubtfully accolding to Froy, from ()ftringen. Engelberg (!), Pfaitfel's and Riagatz.

Digne, vi. 1499 (Li.-lim.); vii. ()1 (Lmm.); Entrevaux, vi.-vii.

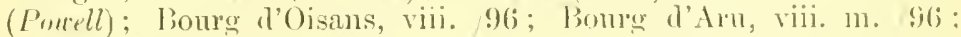
Pré St. 1)idier, viii. b. (9), ab. but worn (T'ute) ; about a mile helow St. Martin V'ésulie, hetween that place and Venanson: St. Sinvent (lim.); Certosa di l'esio, v. e., in mpper valleys (Nomis); Botzen, vi. 2001 ; Sarnthal, vi. 28 ()1, ab. (Lome); Mendel, vii. 95 (Luen.).

Directions of Yar, (a.) size of blk. spots; occasionally much diminished ( 1 is. . 
(b.) coalescence of blk. markings, culminating in :

ab. Conjuncta, Tuti: with large blk. costal bloteh, cl. blk. line mited with next row of spots, and margl. united with antemargl. row mp.s. f.w.; cl. blk. cloud, and margl. series of wedge-shaped streaks up.s. h.w.; un.s. f.w. with wide cl. blk. transverse band: h.w. with inn. half yell. and onter balf reddish-prp. without darker markings.

Loc. Pré St. Didier, viii. m. 99 (T'utt).

[Obs.-In Col. Agassiz's collection is a specimen from the Tyrol, with the blk. spots up.s. h.w. prolonged into dashes.

B. Ino, liutt. (J)ictrnna, $/ / 6$.) ; 40mm. Fd. plt. Spirwer armurns, S. ulmaria, San!nisorba ofjicinalis, linbus, L'rtica, ise.

o darker than $\delta$, and th. border line un.s. more distinct.

Dist. Char. prp. suffusion nu.s. h.w. v. slight, and confined to outer cl. band, also distinguisher from l'aphue by its much smaller size.

Loc. Wanting in the Basle district, and gen. scarce in the N. lowlands of Switz., but otherwise gen. distributed throughout the region, though sometimes rather local, reaching above 5000ft., vi.vii. The whole length of the Jura, e.!., Tramelan (Frredat); St. Georges, vi. 3002 (I\%l.); St. Cergues, vi. 26 ; vii. 20 (l;.) ; Rhone Valley, e.\%., between Villeneuve and Bouveret (Fis.) ; Lavey, vi. b. 97 (Wh.); and up most of the lateval ralleys, e.y., Pont de Nant, vii. 24 (1;i.); Villars-sur-Bex, vii. 02 (1/oss); Zinal, viii. 502 , c. (li.-lim.); Turtmannthal, ab. (Far.); Ac. It. Barry, vi. 29, 1900,

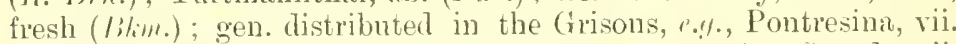
95 (Miss ftm.); Davos, viii. 2, 1900; wools opposite Guarda, vii. e. 1900 , c. $(r / \mu)$; (ampfer (Joms); Val Bevers, vii., rather c.

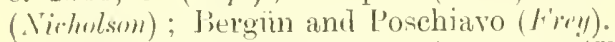

st. Michel-de-Mamienne, rii.e., worn (Thtt) ; Godessart, vii. $3 / 92$ c. (Norris); gren. a poor form in the Passes Alpes (Kan ); Alpes Maritimes (lim.) ; Prés St. Didier, viii. h. 98; Commayemr, viii.

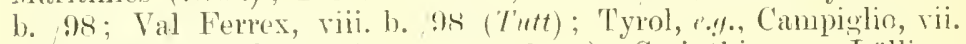
$95(\mathrm{Lmm}$.) ; Salzhurg, vi. e. 1900 (Lant) ; Corinthia, r.!., Lölling, vii. 8. $97(1, m m$.).

Directions of Var. (a.) tendency to darker up.s., culminating in: var. Zinalensis, Far.: with v. il. appearance f. and h.w., the basal half of h.w. entirely blackish.

Loc. (In the left lank of the Naviganza, nearly opposite /inal. viii. 18,02 , still fresh $\left(\mathrm{F}^{\prime}(1\right.$.$) ; consiclered rather a local race than$ all ah.

B. Amathusia, Fisp. ('Titania, /1\%.) ; $45 m m$. Fd. plt. riola mirabilis, l'nl!!!numm bistortu, de.

$q$ rather larger than $\delta$, and with rather more prononnced markings un.s. 


Dist. Char. redtish-pru. of h.w. with conspicuous dog-toothing it ollt. Mill's.

Loc. A mtn. species, but to he fomed alunost everywerc within its range, wh. is practically the fir resion, throngh the whole alpine area : also in some locs. at lower elevations, r.,. Lanterlommen, abont $2600 \mathrm{ft}$. In many places it is ab., esp. in meadows: vii.-viii. At Susil, ri. 26999 , the o s were lighter, and both sexes larger than in Switz. (li.-lim.).

Directions of Yar. (a.) Im.s. h.w., prp. sometimes replated by brick-red, almost the col. of limplitr. s!me uns.s.

(b.) tendency to increase of blk. I1p.s., culninating in:

ab. Nigrofasciata, line. : with broal cl. blk. band f.w.

Loc. Hitherto only reported f.tom Mt. Chemin, mr. Martigny, vii. (l'al.).

B. Dia, l.. : :3:3mm. Fr. plt. violets.

o gen. slightly larger and slightly lighter than $\delta$.

Dist. Char. sharpmess of apical ang. h.w. in connection with larye blk. spots up.s.

Loc. One of the most videly distributed and often one of the commonest of the tribe, in the lowlands, and up to abont $3000 \mathrm{ft}$, gen. in 2 broods, is.- 1 and vii.-ix., but in forward seasons in 3 broods: e.!., I took freshly emerged specimens in the same field at Veytaux, iii., ri., and ix. 99. Mr. Rowland-Brown took it at Digne, iv. 6, fresh, and x. 16, nearly over. 02 ; $\mathrm{II}_{\mathrm{r}}$. Lemann having taken it there, ri. 90 , and vii. 91 , wh. seems to point to 3 broods in that loc.

Directions of Yar. (a.) occasional tentency to lilk.suftusion up.s.

(b.) occasionally v. large spots up.s. ( 1 is.).

(c.) depth of prp. colouring un.s. h.w. r. variable.

B. Pales, Srhifi: : $35 \mathrm{~mm}$. Fd. plt. violet by preference, but will eat almost anything.

$f$ with larger and deeper blk. markings than $\delta$; un.s. gen. paler.

Dist. Char. sharpness of apical ang. h.w., in connection with surall b)lk. markings, 11 s.s.

Loc. Type not on the Jura, but otherwise gen. distributed over the hejghts of the region, often c. and not infrequently ab. from 5.500ft. to abont $10000 \mathrm{ft}$. The type, however, seldom ocens below $7000 \mathrm{ft}$, but is to be found on almost all the heights from the Jicunese Oberland to Styria, on the E., aml the Alpes Maritimes on the S., vii.-viii. 
Directions of Var. [By far the most rariable of the tribe; all the vars. are larger than the type.

(a.) gradual predominance of yell. over redprp. un.s., culminating in :

var. Isis, 1/\%. (Altaica, (irmmm); wh. has also up.s. Austed with blackish.

Loc. Not scarce on the bushy slopes of the higher Valaisian Alps, e.\%. the Forclaz, Val Ferret, Val d'Anniviers, Riffel, Schwarzsee, Simplon, dic. (Fir.); Campfer (Jomes), \&c.

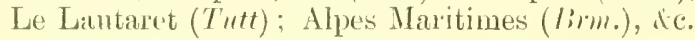

ab. \& Napæa, /ll.: an ab. of Isis 'q, having up.s. shot with a dull purplish tint.

Loc. With 1 isis, $\bullet_{0} /$. , at head of Tal d'Anniviers, viii. 197 (li.-linn.); Simplon, 6th Refuge: Val de Bagnes (Fis.); Daros, viii. 1, 1900 (slom ) Pontresina, vii. 84 (Lmm.), de.

Mont de lib Saxe, viii. b. 94; Lauzon Valley, viii. m. 94; Cogne, viii. m. 94; Falzarego Pass, viii. b. 95 (T'utt); Mendel, vii. $95(\mathrm{~L}$.mm. $)$, die.

Obs.-"A r. tine almost blk. \&, vii. 28, 1900, Brenner" (Ki.-Brn.), is probably to be relerred to this ab., or the next.]

ab. I Cinctata, l'ar.: a further ab. of Isis, less shot with prp. but with a broud band of mited illk. spots across f. and h.w. up.s., narrowed nr. centre f.w. by an or. streak wh. runs into it; outside wh. is at row of large blk. spots, failing only at costa of each w.

Loc. 'This magnificent form is so far' only known from Barnaz, Dent du Midi, vii. 3102 ( $/$ 'is.)

(b.) ull.s. f.w. with conspicuous blk. spots (wanting in type).

var. Arsilache, lisp. (Inducta, spuimblertf); wh. has also rounder ws. than type.

Loc. At lower elevations than type, $\%$.., Tramelan, on the Jura

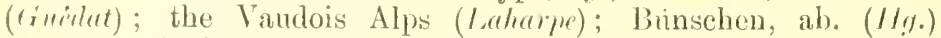
moors at Einsiedehn, c. (I'aul); between Eggiswyl and Rothenbach, at about $2200 \mathrm{ft} .\left(11 .-I^{\prime}\right)$; round little lakes below Campfer and St. Moritz (. Iners), idc.

Tribe Mexıtenn: lryb. l.

Genus, Melitæa, filli.

This genus, some of the sp. of wh. are not easy to distinguish, divides itself maturally into 3 groups. In the 1st the colouring and markings of up.s., exc. suffusion at base, are reproduced in a more or less washed-out form on un.s. The nervures abd transserse lines are lolk., the interstices being filled, in the form of bands, with or.-red and yell. 




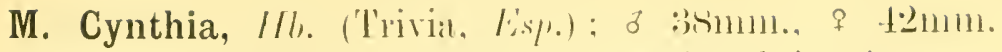
Fd. plt. I'lanturn, loinlu, de. ; I. sometimes hylo twice.

o with yell. replaced hy wh. up.s., o with yell. and red closely approximating, "1.s.

Dist. Char. 11p.s. h.w. ante-margl. red band spotted blk., having its inn. edge, as well as the nerrures, much suffused with blk.

Loc. Not on the Jura, but otherwise gen. distributed, often c., and sometimes extremely ab. at $r$ high elevations thronghont the region, esp. on rocky slopes; rarely, if ever, below 5500ft., and gen. between the tree-limit and the snow-line: vii.-viii.

Directions of Yar. (a.) lightening of the yell. 11p.s. in $q$ (above the Simplon sometimes tending towarls the wh. of the $\delta$, ats

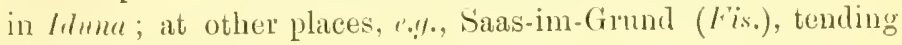
towards Aminia).

(b.) clearness and whiteness of margl. row of spots in $\delta$, sometimes reddish, and sometimes obsolescent on f. or h.w., or both.

(c.) min.s. h.w. absence of the row of blk. dots in ante-margl. band.

* M. Maturna, I. (Cynthia, Lisp.; Mysia, Hb.); $40 \mathrm{~mm}$. Fd. plt. Scabinsa lncida, Planta!n, \&ec.

$q$ considerably larger and somewhat more brightly marked than $\delta$.

Dist. Char. up.s. h.w. red ante-narg. band unspotted (un.s. more distinctly marked than ('ynthia and Anrinia.)

Loc. V. local, but not scarce in its few hannts in this region. The type is not fonnd in Switz. or the S.IW. of the region, and perhaps eren those of the Tyrol are hardly typical. Pejo, vii. 95 (l.mn.); Anpezzo (f'ar.); Salzburg, vi. e. (Lan!l).

Directions of Var. (a.) loss of brilliancy of red and yell., leading to :

var. Wolfensbergeri, livey: the form found in Switz. and the S.W.

Loc. Vald'Anniviers from Niouc to Vissoye, vi.-vi. (Memet, l'ar.,

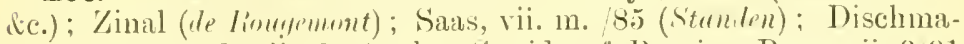
thal, vi. 27, and vii. 201 , ab.; S. side of Bernina Pass, vii. 901 ( /.i.s.); Val Rosegg, at about 6600ft. (1/.-l).); Maloja, vii. 85

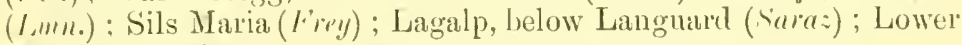
Misox (Killias).

Fenestrella (Kan"); St. Martin V'ésubie (F'ar.); IIts. of Modane, Saroie (hane).

Obs.-Among the specimens taken by Mr. Fison in the lingarline in 1901, is a nust remarkible $\delta$, in wh. the middle left leg is replacerl by a tiny wing, having the appearance of the imm. marg. of a h.w. With the fringe, about smm. in length and $2 \mathrm{~mm}$. in blealth. It is quite detached from the norual wing, 
wh. is perfect without it. It is the more curious, as the leg is a true limb, wh. the wing-structures, correctly speaking, are not.]

M. Aurinia, lint. (Artemis, Hb. : Maturna, lisp.) ; $40 \mathrm{~mm}$. Fil. plt. scabious, plantain, ice.

o larger, and with broater and lighter markings than $\delta$.

Dist. Char. up.s. h.w. red ante-margl. band distinctly spotted with blk., the blk. nervures being r. clear and well defined.

Loc. (ren. in minshy spots, but sometimes in r. dry places, r. in. and ri.; distributed over the whole region in the lowlands and often up to $1000 \mathrm{ft}$, above wh. a break oceurs, val. Merope not appearing below jooft., or thereabouts. As liry, who speaks of it as being found all over Switz, adds that he has never talien it, I give a few loes: Verrier, r. 17.-22; Helmance, vi. 14 (lil.) ; Caux, vi. 97 ; Lavey, r. 27, ㅅc. 02 ; Brig, v. 1603 , v. brt. (1\%.) ; JeurBlûlée, above Fully, v. ab. (l'ar.); Bisbinno, vi. B (Mayer); Weissenburg, r.e. (1/\%.): the Jura (Frey): It. Barry, vi. 28, 1900, neally over (likm.); Inumen, swampy grt. by lake, r. 18:88, r. ab. (/ntchinsm); and, is a contrust, $\mathrm{V}$. ab. on the dry $\mathrm{N}$. side of ('halpigny ( 1 is.).

At Digne, is. e. 97, r. ab., mostly var. Litumis, but some var. l'mincialis ('T'utt).

\section{Directions of Yar.}

[Obs. - This is it most rariable sp., being rarely exactly similar in any 2 district: ; and although certain forms are v. distinct, yet intermediate forms exist between the type and rars. and between the vars. themselves, exc. in the case of Merope, wh. is so isolinted that it is doubtful whether it has not obtained specific rank: feren the specimens bred by the Rev. .l. s. St. John do not necessarily tell agamst this view, though they go fall towats establishing the phylogeny of $1 /$ erop.). The different forms we rather vars. than abs. as they are mostly local races, foumd, however, as abs. in loes. in wh. other foms predoninate.

(a.) size: esp. a great diminution at high altitudes, forming:

yar. Merope, ''rmme' : 32-36mm., col. much washed out, and blk. nerrures much suftused.

Ols.-Werope varies greatly in amount of suffusion, and the depth of colouring up,s.」

Loc. In more or less numbers in marshy places on nearly all the bigh Alps from 5500ft. almost to the snowline, rii.-viii., e.:\%, I'ont de Nant, vii. 18 (lil.) ; Alolla, Pas de Chères path, vii. 13̈, «(., 1900, rathel worn (likm.) ; Riffelalp, ab. (Postans) ; Simplon Pass, vii. 1001 ; vij. 24,99 , not c., v. dk. with yellowish wash $\left(1 H^{\prime} \%\right.$.); Uper lingadine, v. al., esp. Alp Laret, nr. St. Moritz, vii. (Nichol. soili): Guarda, vii. 22-31, 1900 ; Fusio, vii. 1-12 99; Pontresina, vii. 1-21, 1900; Heuthal and Val Tuoi, vii. m. 1900, v. ab. (c/l\%) ; de.

Le Lantaret, viii. b. 96 (Twit); Larche (l'orell); Alpes Maritinnes (lim.) ; P'ejo, vii.95; Campiglio, vii. 95; Heiligenblut, vii. $25 / 97(L m m$.$) .$

(b.) closer approximation of tint in the red and yell., leading to: 


var. Artemis, fubl.: with almost mniform fulvous grol. col. and well-dereloped blk. markings.

var. Signifera, hame: with redlish fulvons gret. col., but slight straw-col. in out. band f.w.

var. Ochrea, Twlt: with grd. col. miform ochreous: no red.

var. Brunnea, Thtt: with uniform bru. gred. col. resembling that of Cinxia.

(c.) a gen. paling of hoth tints, the red becoming yellower, the yell. more ochleous.

yar. Provincialis, liwh.: in wh. the Ak. markings are also lighter and less conspicuous.

Loc. In Swit\%. only as ab. ; (ilion, 1 \& (Aluper); 1 q (Fis.).

The usmal form at low elevations in the Alpes Maritimes; Hasses

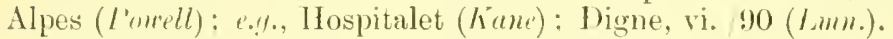

var. Iberica, (Hth. (Desfontainii, Limbr.: Desfontainesi, /.-s.: beckeri, l,rl.); in wh. the fulrous tint yet further predominates.

Loc. Mt. Vimaigrier; Nice; St. Martin Vésubie (IMm., identified by styr.).

(1.) conspicnoms brightening of red and yell., approaching towards Maturna.

yar. Orientalis, 11.-S. (Pl'xelara, liane).

Loc. By no means uncommon in Switz. esp. round the head of the Lake of Geneva; Glion; Canx; bankis of the lihone at Boureres (IIh.); ab. at .Jemr-Brûlée (F'ar.); C'hampéry, vi. 202 ; Le Prese, rii. 1201 (Fis.).

ab. Yirgata, T'utt.

(e.) el. pale band undiviried at costa:

In the 2nd group the un.s. h.w. is divided into 5 farly regular bankls of alternate yell. and or.-bro., moro or less ontlined in blk., the inner deep-coloured band enclosing, or nearly enclosing, a yell. spot, grd. col. of up.s. gen. nearly unicolorous, though in J'hrite showing, in some forms r. clearly, the bands of the $\mathbf{1}$ st group.

M. Phœbe, Kmmele (Corythallia, lisp.); Hmm. Fil. plt.

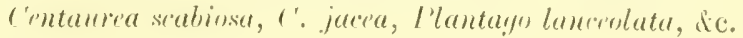

$q$ gen. larger than $\delta$.

Dist. Char. up.s. gred. col. redilish or., at el. band on each w. and imm. band f.w. and a spot nr. base of h.W. heing somewhat lightel.

Loc. Widely distributed, but not fomnd everywhere, c.\%, wanting in the lierne, Ziurich and St. (iall districts (Frell); but fommd in the

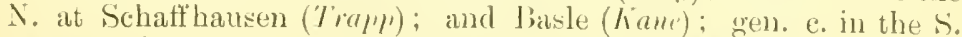
(antons, both in the lowlands and alps up to joouft. and in the Engarlin as high as 6.j00ft. : 1.!., Jura (Fry): Versoix, viij. 16, and uther places nr. Geneva (Lil.); Les Arants, viii. 2/26 (Li.-Lim.); 
lihone Talley and lateral valleys, e.\%., Sierre, vi. 21 (I/im.), dic.: Tisp, vi. 3002 (Shldtur); Bérisal, v.c., osp. from 2nd Refuge to (ianter Brilge, vii. 98, ic. ( $11 \%$.); c. in the Grisons, $\bullet . \%$, Silser See, vii. 1 !5 (17iss l'tn.) : Pontresina, vii. 11. 1900; nr. Guarda,

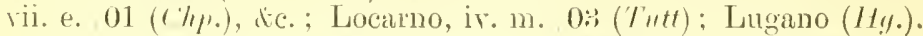

Grésy-sur-Aix, vii. e. 97; l'ourg st. Maurice, vii. e. 91; Petit s't. Bernard, vii. e. 94; La Grave, viii. 12. 96; Larche, vii.e. 1900; Abries, riii. m. 1900, ab. (Tutt) ; Diøne, vi. 90, vii.91 (Lmm.); St. Martin Vésubie, de. ( $\left./ \mathrm{r}^{\circ} \mathrm{m}.\right)$; Pré St. Didier, riii. b. 9s; Courmayeur, viii. 1n. 98; 'T'orre Pellice, viii. 201 , r. ab.: Susa, just appearing, viii. 1997 (Tutt): Olgiate, v. 98, and viii. 95, bere apparently double-brooled (Mis litn.); Vill Malenco, vii. 7, 1900; Campiglio, vii. 9.5 (I,mm.) ; Mendel Pass, vii. e. 95 (T'utt) ; de.

Directions of Var. (a.) size, tendency to become noticeably smaller, culminating in :

ab. Minor, fry: $38 \mathrm{~mm}$. and less.

(b.) a r. marked lightening of the pale bands giving a much more variegated appear-

yar. Occitanica, St!rl: ance, known as :

Loc. The warmer parts, esp. Varen, and the S. site of the Simplon, where specinens are much finer than those of Granada: also nr. the Ganter Bridge (lar.) ; Pfynwald, ri. 24 ; St. Nicholas, vii. 20.98 (likn.).

(c.) a marked lightening of the darker portions, and obsolescence of blk. up.s., esp. at bases f. and h.w. and centre of $\mathrm{f} . w .$, some of the blk. being replaced by brownish.

ab. (in S.l. Lurope var.) Etheria, Erorsmam.

Loc. Martigny, vi. 1902 ( $11 \%$.) : Bad Alreneu, rii. st (Imm.).

(d.) number and size of blk. spots un.s. f.w., esp. the last, wh. is sometimes a thick sq., sometimes consists of 2 curved lines placed horizontally back to back.

M. Cinxia, I. (Delia, Rirlil.; Pilosella, Lisp.) ; o $36 \mathrm{~mm}$. o 40mm. Fd. plt. I'lantayn lancevata, \&c.

\& Aecidedly larger than $\delta$.

Dist. Char. up.s. gra. col. unicolorous or.-lirn.; h.w. up. and un.s. with ante-maigl. row of small blk. spots.

Loc. I. gen. distributed and often c. in the lowlands and lower untu. slopes, up to about 3500 ft. occasionally much higher, r.-vii.

Directions of Var. (a.) size: gen. beconring smaller at higher elerations.

Obs. Mr. Lowe mentions one on Mr. Crammont nr. the snow, vii. $7 / 02$, so small that it was taken, before eapture, for I'arthenie var. I'uriu.

(b.) increase or decrease of blk. markings. 


ab. Suffusa, Tint: in wh. the blk. encroaches on the grd. col.

ab. Obsoleta, Tutt: in wh. the blk. is partially obsolete, and more of the grel. col. appears.

ab. \& Pallida, Tutt: in wh. the blk. also encroaches, and the grd. col. is much paler.

var. Diniensis, II\%. in wh. the ante-margl. row of lik. spots ip.s. h.w. is absent.

Loc. Digne, e.!., v. 2002 (slopme).

M. Trivia, Shlhif. (Lhigenia, lisp.): :36mm. Fr. plt. mullein.

q without yell. spots on aidomen.

Dist. Char. broad blk. mary. mclusin! or.-brn. lunules; further distinguished from Milyma, wh. it otherwise resembles, by its duller col. and bli. neremes.

Loc. liotzen, iv.-r. and ri.-vii. (smuler); mtns. of Piedmont (Kan'). Directions of Yar. (a.) increase in size.

( ?) var. Fascelis, Kis\%. : wh. is also a brighter chestnut-brn.

Loc. (?) Pas de Suze (hame).

M. Didyma, H'hs. (Cinxia, Lisp.); 42mm. Fid plt. I'lantary, C'entanra, Linaria inlyaris, sc.

o grd. col. of all ws. alike, o with grd. col. f.w. lighter than h.w. (in type a lighter shade of same col.).

Dist. Char. up.s. h.w. grd. col. brt. or.-red ( 8 looks almost scarlet on the wing), nerrures nut bll. (though dk. in some forms of $q$ ).

Loc. Gen. distributed and often al)., but wanting in some few districts, e.\%, the Emmenthal and Jiurglorf $(1 / .-1 \%$ ); in 2 broods ( $/$ rey) at lower elevations, vi. and riii., certainly only one at higher altitudes, rii.-riii., gen. 11 to $6500 \mathrm{ft}$; a r. small o not far from the snow on Mt. Crammont, vii. 702 (Lome).

Directions of Yar. (a.) size: considerable (ny smallest $\delta$ is $321012 .$, my litrost o $181 \mathrm{~mm}$.)

(b.) grid. col. esp. in $q$, forming several vars. (in Switz, exc. Alpina, abs.).

yar. Alpina, st!r.: "lp.s. f.w. with greenish tinge, h.w. deep red. brin.; o $r$ slightly spotted.

Loc. Jy no neans confined to the mins. notwithstanding the name, though found there commonly, r.\%., Bérisal, vii.-viii, ab.; but also between Aigle and Sépey ( $11 \%$.); between sierre and Vissoye (Far.); at Sierre itself and in the Pfynwald the type is more usual; Martigny; Nater's; the Jura nr. Basle, de. (l"at.); Pontresina, vii. 9.; (.liss Ftur.), \&ce.

Larche, vii. e. 1900 ; Abriés, viii. b. 1900 (Intt). 
var. Meridionalis, stm : $\delta$ grd. col. v. brt. red, $q$ f.w. greyish and h.w., exc. for dli. suftusion, tinted greenish.

Loc. In hot places with type: $e . /$. , c. sone years in the vineyarts beyond la Patiaz; Sion: Sierre; dic. (Far.).

var. Græca, stım: of with broad blk border, $q$ of greenish-gr. tint ; "1u.x.h.u. in? r. rivh sharles.

Loc. Scarce: gen. in hot places only: Timeyards of Martigny (l'ar.) : Terey, viii. 3001 (helyme).

var. Occidentalis, vt!r.: $\delta$ and $q$ unuch paler'

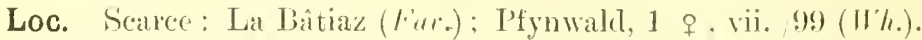

Olgiate, viii. 9s, with whole up.s. rich crean-col. (Misis litu.); Alpes Maritimes (lirm.). The small local lace on the Holomites; vii. m., with lighter, yellower, f.w. (li.-lirn.), should probably be referred to this var.

[Obs.-A r. curious and beantiful ab. Was taken close to the Hotel at st. Nicholas, vii. 23,1900 , by Mr. Bucknaster: up.s. t.w. grit. col. yell. bin., with border of blk. wedges, and ante-margl. line of blk. dots, much blk. at base, extending along two-fifths of costa, and one-third of inn. marg., containing 2 yell. spots in the upper and 2 in the lower part: h.w. deeper in col. with border of blk. wedges, d. line of blk. disshes, and large blk. blotch from nr. base, following but not touching inn. marg.; un.s. f.w. few and small blk. surots: h.w. pale yell. with ante-nargl. line of short blk. dashes, base or. edged with blk., rather broadly internally, narrowly externally; out. marg. f. and h.w. un.s. dashed with blk.]

The $3 \mathrm{r}^{\mathrm{d}}$ group consists of those sp. in wh. the lt. cl. band un.s. h.w. is preceded exteriorly by a band nsually containing at its out. edge a row, or part of a row of or.-brn. or yell.-brn. crescentic spots, and at its inu. edge a succession of narrow mottler spots, wh. are often more or less repeated at the basal edge of cl. lt. band: grd. col. mp.s. nearly unicolorous, though the lighter hands are sometimes clearly indicated, esp. in l'arthorir $q$. The sip. of this group are by far the most diffcult to determine, though by no means so difficult as is usmally supposed, if a number of specinnens can be compared, exc. in the case of certain extreme abs.

Intermediate between the ond and 3101 groups is :

\section{Deione, //\%. : 40mm. Fd. plt. Limurin menspulinsis} and $L$. enlyaris.

$q$ less unicolorous up.s. and lighter un.s. than $\delta$.

Dist. Char. mn.s. h.w. almost like groul' 2, but with some traces of the band characteristic of gronp $: \because$ : spot enclosed in inn. or. band more or less triangular, with apex resting on lowest of lt. basal spots; un.s., and often up.s., f.w. with a $>$-shaped blk. mark nr. inn. marg.

Loc. Digne, vi. 1099 , c. at privet by the side of rivulets (li.. lim.); r., vi. and viii. (l'mmll); Certosa di T'esio, mr. Beinette, vii. $18 / 92$ (Norris); St. Martin Vúsubie, a few, vii. b. 99 (Lam/). 


Directions of Yar. (a.) grd. col. darker and duller.

yar. Berisalensis, fint. (false lierisali, lïhl). The swiss form.

Ohs.-After much correspondence, and the examination of many specinens, I an fully assured that this is the Swiss form of .11. Mrime, as M. Puingelel supposes: the un.s. is identical, the up.s. differs from that of leione from h Valette) only in being darker in grd. col. and having the blk. markings more pronounced. It is beyond my comprehension how anyone can regard either Deione or Berisalensis is a form of Athali, the m.s. alone would prechule snch a designation. I fail to see even a superticial resemblance, and the life-historie; have nothing in common beyond what is common to the whole genus. Further. the 2 broods of Perisalensis come ont, one before, and the other after, the one brood of Athalia in the Rhone Valley. On the other hand, besides the close similarity of markings, the broods of Deione and linvisulensis both feed on linaria, both are regularly double-brooded. appear at approximately the same time, and in both the earlier brood is noticeably the larger; both, agatu, are singularly constant in their special churacteristics. The difference between the Spanish and S. French specinens of leione seems to point in the same direction, the Spanish form being as much lighter as the Swiss is darker than the French.]

Loc. Hitherto only from Martigny (Tour de la Bittiaz through the vineyards to Plan Cérisier), and Saillon; v. e. to vi. e., and viii. m. to ix. nt. ; r.!., Martigny, v. 28/01, ab. (Fis.); vi. 1402 ; vi. 2501 , rather worn; viii. 27, 1900 ; ix. $1 / 99$ (Wh.), de., \&c.; reported also from the vineyards at Varen, vii. 302 (sholom, identifierl by $(\mathrm{h} / \mathrm{s})$.

[Obs.-This loc. is a v. likely one, the date, though lather late. by no means impossible, but specimens intermediate between this and thulia are mentioned. which makes one panse before fully endorsing this loc. 11 y correspondence on the subject, and the arrangement of rarious collections, have made me v. doubtfnl whether half a dozen collectors exist, ontside the habituss of the lilrone Valley, who really know Berisulensis when they see it, still less when they do not.

Directions of Yar. (a.) $2 \mathrm{v}$. suffused specimens, becoming ahnost blk. (IIschl.).

(b.) 2 specimens with the $>$ mark divided thus: $\asymp$ (lis.).

Obs.- The name Berialensis is a complete nisnomer, it being an open secret that the original type specimens came from Martigny, whence the captor went direct to Berisal, his captures from the 2 places becoming mixed. It has never heen taken at Berisal. and it may be safely predicted that it never will be. It is $v$. likely that specinens from the Simplon Pass purporting to be Berisulensis are responsible for much of the confusion through which it has been anp. poserl to be a var. of Athrilir.

M. Asteria, Fr. (Asterie, /I.-S.); $30 \mathrm{~mm}$. F(l. plt. mknown.

o lighter than of.

Dist. Char. un.s. h.w. a single dk. margl. line (the other sp. have a double one).

Loc. Only at high elevations in the E. Swiss and Tyrolean Alps and l'sedmont, vii.-viii. On the Calanda ("Wmen); above ('oire (Krir-hbumer); above Churwalden (1/!\%); on the (Hurgaletsch above Parpan ('aflish); Havos, viii. 2, 1900 ; Pontresina, vii. 1-21, 1!)(0): Guarda, vii. 22-31, 1900; Hentlial. vii. 11. ant Val J'noi, vii. e. 1900 (C'hp.); at the top of the Albula Pass (firey); reported also 
from between Zermatt and the Gornergrat (Guene): considering its Piedmont hannts this is quite a likely loc., and I have myself taken 3 specimens on the Simplon, vii. 1m. ()1.

Larche, rii. e. 1900 ; Abriès, riii. m. 1900 ; Pré St. Didier, summits of the Crammont and Mt. de la Saxe, vii. b. 98 (Tutt); Jirenner on the Postalp, rii. 28, 1900, os worn, os tine (Ii.-Iim.).

Obs.-. - An insect $v$. inconspicuous on the wing. and with a bee-like" flight" (li.lin.).] Directions of Yar. (a.) some specimens slightly more trans-
parent-looking.

rObs.-Frey observes that this sp. is rich in vurs. : I have only once taken it. but all that $I$ have seen in collections are singularly constant, and all those of my correspondents to whom I have addressed special enquiries on the subject bear this out from their own experience.

M. Aurelia, Nicliol (Parthenie, I/lst.: Athalia minor, Ess\%: Athalia, Hb.); $32 \mathrm{~mm}$. Fd. plt. Molamminm and plantain.

o lighter in markings than $\delta$.

Dist. Char. small size, together with breadth of blk. markings giving a chequered appearance.

Loc. Apparently contined in Switz. to the Talais, the Grisons and Tessin, mostly at low elevations, but rising in places to nearly $6000 \mathrm{ft}$; local in Valais, but found in many places: Visp, on an open bank about a mile along the Brig roud, vi. 16.99, c.; Rhone meadows at Sion, v. 20, 1900(Ih/.); Périsal, viii.2,97 (li.-lin.); vinevards at Martigny; Mt. Chemin; Fully ; Sierre; Cran ; Turtmann; Visperterbinen; Stalden; Forest of Fiesch; Belalp; Jortelalp: bitrenfallenalp; vi.-vii. ( $/$ 'r.); Beroiin in a few meariows only, vii. 11, de., 89 (Jïhll); Maloja, vii. 88 (Lmm.); Monte Jíré, viii. 18 02 , dk. specimens ( $F \ddot{i s .}$.

Susa, vi. 24 !!) (li.-lirn); Tal Solra, viii. 2002 (lis.).

Directions of Yar. (a.) lightel grel. col. and narrower lilk. markings.

yar. Rhætica, liry.

[Obs.-As lihetica is sometimes spoken of as a darker form, I give the original description translated from Frey's "lepidopteren der Schweiz," p. 30: "smaller, lighter red-brn., less dull, with narower blk. markings, the o not ratrely with $\%$. lt. hm. rows of spots."

Loc. ('oire, r. c. (c'allisel ) ; vii. 301 (tis.) ; occasionally among the Visp specimens ( $11 \%$.).

(b.) general darkening of appearance mn.s.

yar. Britomartis, Assmamn (? Veronice, Hortmeister: ? Aphaen, fir.).

[Assmann's original description is as follows: "Melitata alis integris, ferrugineis, nigro-reticulatis, posticis subtus flaridis, fascris tribus cimnamoneis, maculisıue dnabus sub-albicantibus, linea nigra ante marginem exteriorem flavm vel cinnmoneum." This is not a r. enlightening description, but liakl, who had the opportunity of 


examining a specimen identified by $A$ swmann himself, remarks that he shonld have taken it for l'arthenie by its up.s., lut that on the un.s. it showed in the ont. (lk. band of the h.w. the blk. spots peculiar to Irityma. This at once puts out of the question syulu's description in the schmetterlinge Europas, 190:, "border, lases, and cross-lines broader and blacker, the palpi darker, and the :3 rel-brn. bands nu-s. h.w. standing ont more strongly." Assmamn considered Jritmmantis to be a listinct species.; liwhl. considers that if it is not, it is probably a hybrid between I'arthrnie and lictyma, and not in any case a var. of Awrlia: the hybrid theory was a firrourite one with Sirhl, and in this group is possibly far more often correct than one is apt to inagine. The following: locs. refer to the var. as described by Assmann; Mr. Fison's specinens from Monte Bré and Tal Solda rould come under this head according to spuler and others.]

Loc. In the Valais as an ab. only; Sion; Sierre; Naters; Laquinthal ( $f$ 'ce. $)$.

\section{Parthenie, Milih. (Parthenoüdes, Ketirstrin) ; :36mm.} Fd. plt. plantain, scabious, \&c.

$q$ lighter and less unicolorous than $\delta$, with whitish bands un.s. h.w.

Dist. Char. up.s. f.w. cl. and ante-margl. bands r. slightly divided by narrow blk. line often broken in midile; $\mathrm{cl}$. band of h.w. in of conspicnomsly broad, and scarcely, if at all, interrupted in the centre with blk. (This smmetimes occurs in Athalia.) Un.s. h.w. with dk. band nr. base gen. lighter and narrower than in Athalia: further distingnished from the latter by the palpi, wh. are golden-bru. above, with a dark line below; $q$ grtl. col. much less micolorons than Athalia $f$, and distinguished from leime var. Brriselensis $q$, which it closely resembles above, by «น.s.

Loc. Swarms in many parts of the Rholle Valley, esp. in 1st brood, vi.-vii. m.; less ab. in the 2nd, viii.-ix; Veytanx, Aigle, Charpigny, Bex, \&c. (II\%.) ; La Bittiaz, Charrat, Fully, Mt. Chemin, Sierre, Salquenen, the Pfynwald, Loeche-les-liains, Visp, Stalden, ke. (far.); also Veyrier, vi. 17; viii. 26 ; Versoix, viii. 1s, \&c. (lil.): Liestal, Engelberg, Meirengen, Interlaken, Brienz, dc.

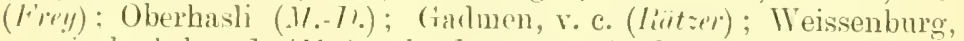
v. c. in both broods (I/!) ; the Jura, $\%$. ., St. Georges, r. brt. (11\%.); large at liasle, '/urich, and in the Grisons, and v. brt; small and $r$.

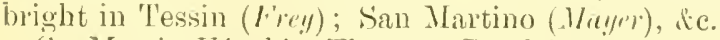

St. Martin Vésubie, Thorenc, Berthímont, ife. (lim.).

Directions of $\mathbf{Y a r}$. (a.) diminution of size at greater altitudes, culminating in :

var. Yaria, M.-J). down to $28 \mathrm{~mm}$. or even less; $\delta \mathrm{r}$. lort. $q$ often with slight greenish tinge. 
Loc. Gen. at high elevations: Evolena, Val d'Anniviers, Kaltberg, the Riffel, Belalp, Rossbortenthal, Kc. (Far.) : Bérisal, viii.

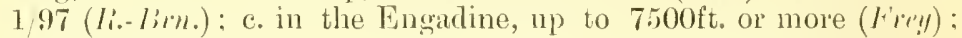
Bernina Hans, vii. 1801, c. (Fis) ; Henthal, vii. 1900 (f/l\%.), \&c.

Trafoi, scarce (1'rey); Mt. Crammont, vii. 702 (Lor'c); Crête de Reychasse (Tutt): at high elevations in the Alpes Maritimes ( $\mathrm{i} / \mathrm{m}$.$) .$

(b.) amount of blk. up.s.

[Obs,-.Mr. Fison has one entirely suffused with blk. exc. border.]

(c.) amount of variegation up.s. in $f$.

(d.) depth of coloming un.s.

M. Athalia, Rott. (Naturna, Hh.): :36mm. Fd. plt.

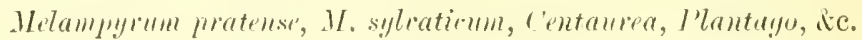
ogen. larger, and with lighter un.s. than $\delta$.

Dist. Char. el. and and ante-margl. band up.s. f.w. more or less heavily divided by blk.; up.s. h.w. with cl. band often suffused, almost always intermpted in centre with blk. (i. Parthenie) and with or.-bru. spot nr. base; nn.s. h.w. inn. dk. band gen. broader at costa than in Parthemir, Aurelia, or Dictyma: further distinguished fron l'arthemie and Awrelia by the palpi wh. are 1 k. brn. above.

Loc. 'Thronghout the whole region, ri.-vii.-viii., rising as high as 6500 metres or more; not, in my experience, so c. in the Phone Valley as I'uthenir. Iirhl observes that the specimens emerging vi. are smaller, and those emerging viii. larger, than the average. He also remarks that the brighter the coloming the rounder the ontline of the $w$; that the specimens from the mtns. of Lower Anstria have r. small blk. spots un.s. h.w. ; and that those from moorlands are gen. darker than the average. Occasionally, in very hot years, a few small specimens, a partial 2nd broor, appear ix.

Directions of Yar. (a.) size: the mtn. specimens are gren. small lint brt. (liiill).

(b.) increase of blk.

ab. Navarina, Nilys-lam!grumps: with blk. suffusion over all ws., leaving ante-margh. row of or--brn. spots.

ab. Aphæa, $/ 1 h_{\text {. : }}$ with 2 bands of or. spots up.s., the margl. lunules and cl. spot un.s. h.w. filled with blk. and a row of large blk. spots un.s. f.w.

rObs. - In Mr. Ficon's collection is a specinen approaching this ab. with inn. edge of ante-margl. band snffused with blk., whole centre of w. 1t. yell, with band of large sitfused blk. spots.

ab. Caucasica, st!y, : f.w. normal, h.w. much suffused with blk.

(c.) decrease of blk.

ab. Corythalia, 116 . (Samonica, Riesen); all blk. markings absent from centre of f.w. up.s.; h.w. much suffused with blk., leaving a single row of or. spots. 




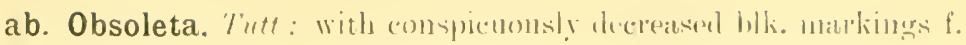
ilul h.w.

ab. Hertha, "wensel: with longh hlk. stroalis m.s. f.w. but less blk. 11p... 1."1.

ab. Yirgata. \%ull: with ol. ol. hand f. and h.w. lenerthened into struaks.

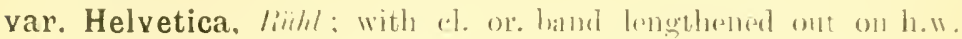

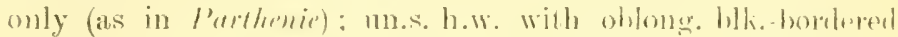

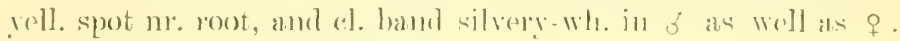

Loc. liereriin and stalla (lïhl).

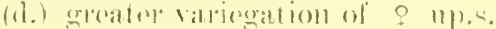

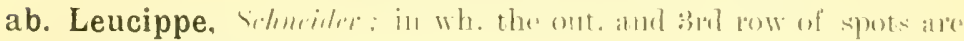
mnch lighloter.

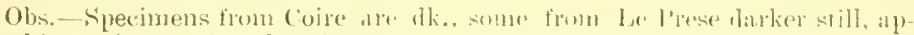
probtehing lictymun in (sol. (l'is.).

M. Dictynna, Lisp. (Corythalia. /l/.) : :37mm. Fid. plt.

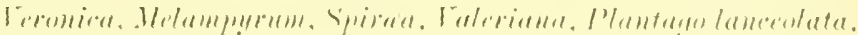
di.

\& with more and lighter markings than o .

Dist. Char. 1. large proportion of blk. on m.s. esp. h.W.. losking

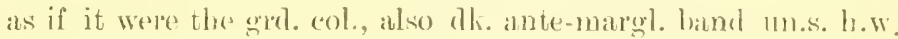
interupted $\mathrm{m}$. costa on ont. sile. and contaning r. alk. spots on the uninterrupter portion.

Loc. Gen. distributed in Switz. in the plains and at lower elevations, and mounting to (ioooft. or mores r. e. and ri. Remarkably fine speeimens on the loft bank of the libone at lionveret. Gen. distributed, also, in the rat of the region, hut apparently not extending to the Basses Alpes or Alpes Maritimes.

Directions of Var. (a.) size: mysmallest of from Vall'Anniviers. is $32 \mathrm{~mm}$; my largest ? from Honveret. $40 \mathrm{~mm}$.

(b.) amount and depth of or.-hrn. mp.s., esp. in ․

(c.) depth of coloming un.s., esp. h.w.

Tribe Vaxessidi; byb. im. (exc. l, ranu).

Genus, Arachnia (falsè Araschnia), //6.

A. Levana, l. : :30mm. Fil. plt. nettle; hyl. p.

o larger than d, with rather lighter grel. col.

Dist. Char. Conspicnoms lt. veining mus. with transwerse lines on

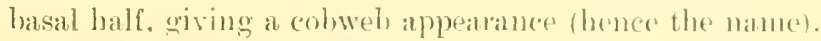

Obs. The searemal dimorphism in this spe is so markod and extlotordinary that nothing is lefi in common lut the chatracter above mentioned amel the

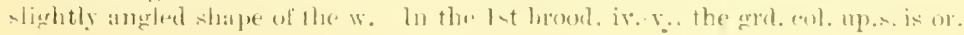


As in $P$. C-clloum, with dk. brn. markings; in the and (and later) broods, vii. viii. (and ix.), known as

var. Prorsa, l..; the cred. col. is blk., with wh. broken bands and or. ante-margl. lines. An intermediate form, v. scarce in natmre, but readily obtained by keeping September chrysalids at an artificial heat dming the winter ( $F(a r)$, is called:

ab. Porima, (M./. : more nearly resemblung Prome, but with wh. replaced hy tawny, and the band on h.w. almost always divided.

Loc. $\quad V$. local; (. round basle, e.t., Liestal (Christ); the Bechburg (L.-s.); c. in the Bernese Mittelland; Schïpfen; Burgdorf ; Perne (.Jïyni); thronghont Oberaargan : Lenzburg (IVschl.) ; Glarns (Hev); Kiupternaseruns above Eilzhach, vi. 19/02; Thalalp, vi. 20, \&e. 02 ; Letana (Fis.); v. scarce in the Grisons; Tavanasa (Briugfer): Ragatz (Fiseminy); also in the Valais, at the ft. of Mt. Chemin; nr. Sicre, esp. in the Pfynwald (Far.); in W. Switz. at Lncens, v. $7 / 8 \mathrm{~s}$ (Huthinsun); also Moudon and Payerne (Frey); (entirely absent from the Cantons of Schaffhansen, Thurgau, St. Gall, and Zürich; also from the Rhone Valley up to Martigny, and from the district bordering on the Lake of Geneva).

The Tyrol; also Wolfsberg, vii. 15/97; Prorsa (Lmn.); Berchtes. gaden, vi.e. 1900 (Lan!) .

Directions of Yar. (a.) size of the dk. bru. markings in Letana.

(b.) size and continuity of the wh. baud in Prorsa.

(c.) namber and extent of thin or. antemarg. limes in Prorsa.

Genus, Pyrameis, $1 / 6$.

Dist. Char. at triples wh. spot from centre of costa, and intemargl. wh. spots from mi. apex half down f.w.

P. Cardui, I. ; :55mm. Hel. plt. thistles.

Dist. Char. errol. col. nn.s. t.w. cherry col.

Loc. 'T'o be fomm serywhere, in many years ab., np to $8000 \mathrm{ft}$; the principal brood emerges in late summor, but the insect is to be seen on brt. Alays during most of the year.

Directions of Var. (a.) lllk. markings contluent up.s.

ab. Elymi, limlir: in which the wh. spots are redaced to small streaks.

(b.) alssence of blk. spots mp.s. f.w. except apical half.

ab. Inornata, liremsom: in which the wh. spots are also larerer (both abs. scarce).

P. Atalanta, L. ; 5.mmm. Fd. plt. nettle.

Dist. Char. Scarlet band across f.w. and border b.w. up.s. 


Loc. $\Gamma$. gren. distributed, but not often nounting v. high, thongh oceasionally to the tree limit: vii. till hybernation, and in springe, but not gen, lo-alpukatring till v.m.

Directions of Var. (i..) division of rod. hund 11p.s. f.w.

ab. Fracta, 'futt: the dli. erret. col. being developed along el. nervure.

(b.) a gren. diuninution of markings.

ab. Klemensiewiczi, schille; red band f.w. shortened at both ends, large costal spot rednced to small wh. lot, red band h.w. shorter, narrower, and without blk. spots.

Genus, Euvanessa, sirulder.

E. Antiopa, 1..; 70mm. Fid. plt. willows, poplars. dec. $q$ larger than ơ.

Dist. Char. Deep chocolate grd. col, with lt. border.

Loc. Throughont the region, thongh seldom v. ab.; flying up to $6000 f$. or more; viii.-ix., and after hybernation, iv.-vi., often in excellent condition.

Directions of Yar. (a.) yell. border after hyb. becomes lighter, gen. ahmost wh., and the bl. spots become more prp.

(b.) enlargement of yell. border.

ab. Lintneri, Fitch: in wh. the bl. spots are consequently reluced. ab. Hygiæa, Heydencich: in wh. they are entirely lost.

Genus, Yanessa, liubr.

V. Io, I..; $55 \mathrm{~mm}$. Fd. plt. nettle.

Dist. Char. a large eye-spot on each w. up.s. those on f.w. gorgeously coloured.

Loc. Gen. c. throughout the region, mounting occasionally up to some soooft. (e.\%. the beights above the Plumenthal, Mirren, viii. 3, 1900, 1 . f'esh) ; rii.-ix., and, after hybernating, all spring.

Directions of Yar. (at.) size: the so-callecl abl. Ioides, Orhs., is merely the result of half-starved larvie].

(b.) loss of eye-suots.

ab. Exoculata, II rymr : with eye-spots h.w. obsolete.

ab. Belisarius, (H,h.: with all eye-spots ohsoletr. and blk. spot: f.w. contluent.

ab. Fischeri. Ftumlfuss: in which eye-spots f.u. are disintegrated sluowing a resemblance to the wh. spots of l'yenuris.

[Obs.--The lase always, the 2 formor usually, are obtained by refrigerating pmpe, hut Far. (Anpplement to the "' lepidoptires du Valais,' 1903, p. 5) says that these 2 ocen here and there with the type.] 
(c.) col. of the prp). in eye-spots esp. h.w., varying from heliotrope to h].

(1.) ocasional appearance of a bl. spot below (ye-spot, h.w. up.s.

ab. Cyanosticta, liernm, : spot raries gratly in size.

Genus, Aglais, $/ / /$.

A. Urticæ, l. : tsmm. Fil. plt. nettle.

Dist. Char. un.s. l.w. erret. col. of large portion, starting from ext. half of inn. maro., of a buff tont, only slightly marlsed with lon.

Loc. One of the commonest as well as most wiklely distributed of butterflies thromghout the resion: found in numbers up to $7500 \mathrm{ft}$. and occusionally nuch higher: 2 or : brools, vi.. viii., and sometimes $x$; But the insect may les seen on warm lays througbout the year.

Directions of Yar. (a.) tint of grd. col. 11).s.: more or less or. in the pert.

(b.) distinctuess of el. band un.s. h.w.

(c.) traces of hlli. ch. himm up.s. f.w.. culmi nating in :

var. ( $\&$ ab.) Polaris, sityr.: in wh. blk. spot of inm. mare. is joined to mindle costal spot.

(17.) obsolescence of the 2 el. blk. spots II])... f.w.

yar. (\& ab.) Turcica, vy!n: in wheh they ale absent. ats is

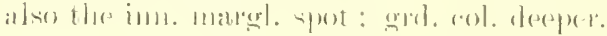

yar. (\& ab.) Ichnusa, limmlli: wril. (o)l. still deeper. ("). spots

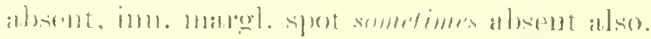

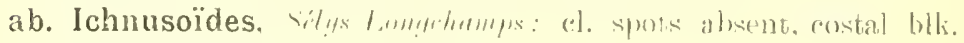

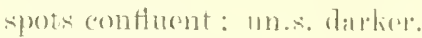

ab. Atrebatensis, listl. : like the last, but with h.w. up.s. entirely suffuserl with bll.

Genus, Eugonia, $/ / /$.

Prevailing col. or.-ben. with hlli. spots, and bl. spote in border.

E. Polychloros, I..: (i(h)mm. Fil. plt. elun and sallow. f larger than 3 .

Dist. Char. allsence of wh. sper nr. anes on costa f.w. up.s.; let.s dli. lirk.

Loc. I. "witoly distributed, but seldom ab., and somewhitu meertain in appearing ; vii.-viii., and, after hybernation, all throngh the spring ; in plains and lower valleys. 


Directions of Yar. (al.) size: j(l1111.-(6.)11111.

(b.) coaluseence of hlli. spots up... f.w.

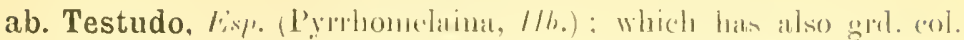
f.w. much lighter, and h.w. diaker than type : a machiticent, but scarec form.

E. Xanthomelas, lisp.: ti(0mm. Fit. plt. willow.

Dist. Char. I. like l'mlychlorm, but with whitish spot on costat

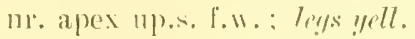

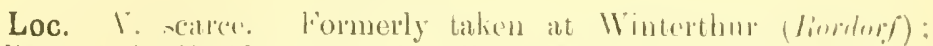
valleys of the li. . Ipls (smmler): vii. to ix., and, after hybernation, in the spring.

\section{Genus, Polygonia, //\%.}

Prevailing col. lrownish-or. with r. Ak. brin. (or blk.) markings. Dist. Char. I. jilgered ont. marg. f. and h.w.

P. L-album, lisp. (V-album. Fibr.: V'an-album, Virerille) : (60mm. Frl. plt. aspen. willow, dic.

Dist. Char. wh. spot on costa m. apex both f. and b.w. (up.s. closely approaches Finfonia, and the outline of the ws. is not so jagged as in other sp., but un.s. is that of Poly!ymia).

Loc. Doubtful whether found in region. Switz. is given in some anthor's, but 1 can find no nore exact loc. and no evidence. Possibly in the valleys of the E. Alps, vi.-viii. (spuler).

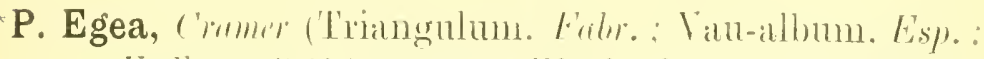
Yalbum, lirlih.) : t.5mm. Fil. plt. elu, nettle, libh's, Lumi-

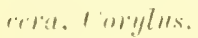

o gent. larrger than of.

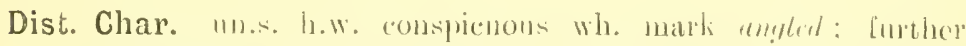

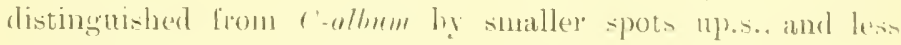
jagged outline.

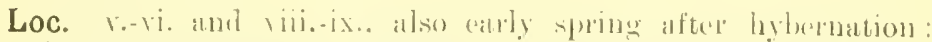

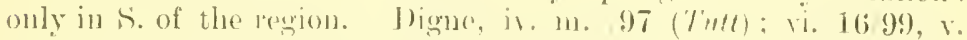

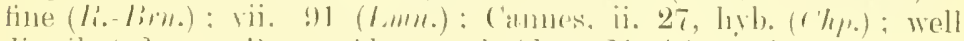

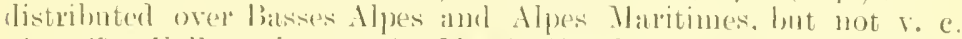

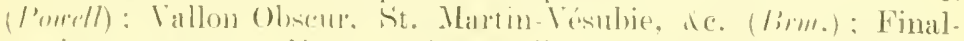

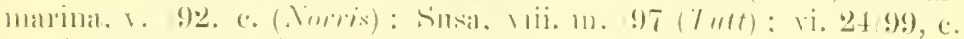

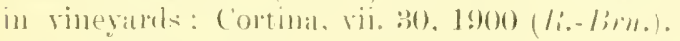

Directions of Yar. (at.) dirkening of coloration:

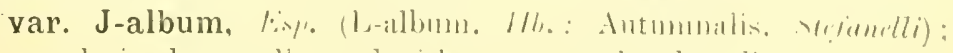
wh. is also sualler and with wore angulaterl ontline.

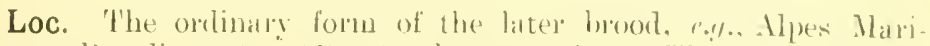

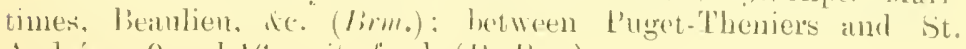

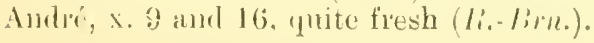


(b.) shade of grul. col. and conspicuousness of narkings un.s.

[These vary in a way exactly parallel with $C$-album, q.v.]

P. C-album, I.; 4 mmm. Fd. plt. currant, nettle, elm. poplar, \&c.

q gen. larger than of.

Dist. Char. un.s. h.w. conspicuons wh. mark, romuted; gen. like a $\mathrm{C}$.

Loc. Everywhere in the region in woods, gardens and roadsides, often ab.; v. e., vi.; and vii., viii.-x., also in early spring after hybernation: not gen. above $4000 \mathrm{ft}$., but in Val Pellice at soooft. ('l'utt).

Directions of Var. (a.) lighter grd. col. up.s.

var. (\& ab.) Hutchinsonii, Robsom (Pallicla, T'utt): gen. in summer brood.

(b.) tendency of dk. markings up.s. to form a. (1. band colminating in :

ab. F-album, Fisy.: wh. Las also the C-mark converted more or less into an F'.

(c.) darkening of borker np.s., culminating in :

ab. Reichenstettensis, limhl; with 19alt grul. cul.; 2 basal spots up.s. f.w. in place of blk. blotch; v. broad border, esp. on inn. marg. ; and h.w. all dk. exc. base and nr. fringe.

(d.) shape of wh. marli un.s.: sometimes pesembles a $\mathrm{G}$, sometimes an $\mathrm{O}$, sometimes a small i inverted, occasionally. in 3 . redaced to a mere line, forming:

ab. Iota-album, Newhinem.

(e.) grd. col. and malkings mus.s.; the more or less uniform dk. un.s. is regarded as the type, the shade of which varies considerably; there are also 2 mam divisions of the variegated form:

ab. Pallidior, l'ta!nua: with lt. grel. col.

ab. Yariegata, Tutt: with dk. grt. (a).. the gin. being often lrominent.

()hs.- The aluve pive only the man formo of the nu.s., wh. ravies almost.

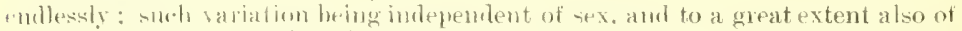
time of energence: it has. howpver, been observed that the hybernating speci

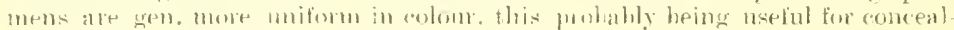
ment in the in intel.

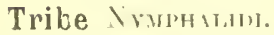

Gerzus, Limenitis, lill.: hỵb. 1. 


Prevailing col. blk. (or v. (lk. brus.) with wh. spots and bands.

\section{Populi, L. ; 68mm. Fil. plt. poplat's.}

Almost blk., of with narow, q with broad wh. band up.s. h.w.

Dist. Char. un.s. h.w. out. marg. It. greenish-bl. band divided by blk. lines.

Loc. Basle and Liestal, scarte (Fry); Canton Aarran, e Bremgarten, Lonzburer, Gysulaflul, de. (ITshl.) ; ("ommoner in the "Mittelland" of Canton Berne, e.\%., Burglorf, Schüpfen, Berme, Aarbery $(1 / .-1)$.) : widely listribnterl, bnt $\%$ scarce in $\mathrm{l}$. Yand (r. infiri); (riyon, vii. 02 , much wom (1/oss); not quite so scarce in the forests of the Valais: e.l., Forclaz, vii. Is (ol (stoper); St. Léonard, Granges, Sierre, Nc. (Far.); not rare at Rossinières (Taslier); in the (antons of Schaff'bausen, St. (rall (Trischler); Thurgan (Enyster), and Crlarts, $\% \%$, Mollis (Her) ; in the Grisons, Coire, Trins, Tliefenkasten (Killias): Le Prese, at side of lake, vii. 12-1501, mostly worn (Fis.); in the . mrat at. Cerones, vi. 26, and vii. (lil.) : Tersoix (Inllien).

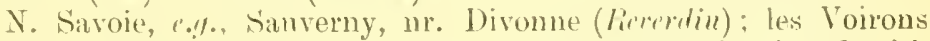
(Fogt): the Tyrol, \%., Sarnthal, vi. 21/01, strongly tinged with bl. approaching col. of Camilla (Lame).

[Obs.-The of gen. rests on the grd. up to 10 a.m., the \& rarely descends before 4 p.m.]

Directions of Var. (a.) tendency towards loss of wh., culminat ing in :

ab. Tremulæ, Fisp.: in wh. little is left but the apieal spots; grd. col. deep snuft-brn.

[Obs. - A transitional form with the wh. $\checkmark$. narrow and mueh suffused with bru.. and the grd. col. bru. without a trace of bl.-blk., is the ordinary one in E. Vaud, at auy rate at the lower elevations: Veytax, vi. 13/97 (ITh.): Aigle, vi. $24 / 98$, and vi. 25, 1900 (I.me) ; Tiniere Valley, vi. 21/02 (charluich): a mile beyond Sépey, vii. 2fi 111 ( Imin.); etc.

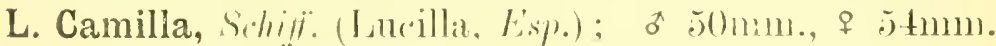
Fid. plt. honeysuckle.

Dist. Char. m1... h.w. ont. marg. 1 row of blk. spots between 22 rows of Indian red, on th. leaden grd. col.

Loc. Thronghont the whole regrion, but not lound everywhere. occasionally plentiful, lont often in small numbers only; in and on the ontskirts of womls. Basle, scarce, 1 sp. x. 11.1 (( / hist) : Oensingen, on the liechburo (Ki...); in the cantons of sichaff

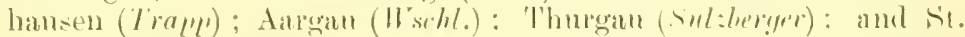

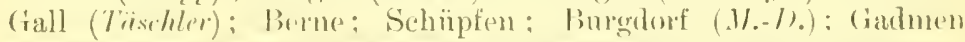

t Note. The faret, wh. has always semed probable, that timilla is at least partially double-broodenl is now placed beyond doubl. Mr. Sloper reared is number of liarve from the lst brood at cilion in 19nes, some in captivily. some placed ont of doors on the fid. plt. Although those in aptivity were rentoved on Zermatt, they emerged in Ingust, and, on returning to Glion in September, at least one empty pupa-case was found on the plant on which he had placert the other larræ on leaving for \%ermatt. 
(lint:m); entrunce to the Klontbal (Fe?l); Weissenburg, up to is. $(1 / !$.$) ; the Jura, e.\%.. Sorvilier (H!.); St. Blaise (Conlern); St.$ Cergues, vi. 26 (I,l.) ; nr. Geneva, Veyrier, riii., Onex, viii. 18 (lil.); gen. distributert in Taud and the Valais, e.\%., Lausanne. vii. 85. not nncommon in gartens (Jomes); les dvants, viii. 596 (R.-l;m.): Veytanx, vi. s!99; Aigle and Sépey, ab., vi. e., and vii., 1900, \&c., Sierre, vij. ant ix. 6\%9 (H\%.); Pfyn, vi. 29 97 (l'ostans); Nartigny: Fully; Sion: Varen : above Greugiols, ab.,

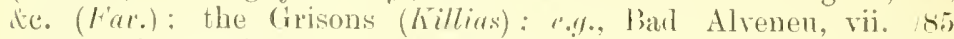
(l.mm.) ; I'ontresina, viii. b. 01 ( ( / / / r.), and foumd singly as high as Eergiin, 450uft. (1;ing).

Savoie, r.!.. m1. lienera, Yroire, vi.2: Jossey, viii. 2, 3. 2t: Moruex, viii. b. (Lil.): Jionlog Sit. Manrlce, viii. b. 98: Bomror d'oisans. viii. 1n. 96: Bincelonette, viii. b. 1900; Grésy-sur-Aix, viii. m. 1900 , suall (T/1tt) : ligne, vj. 499 , al. (li.-lim.) : vii.

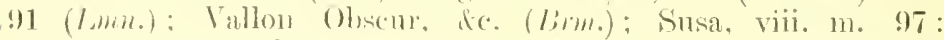
Commayeur, riii. L. 94: Pré St. J)idier, viii. n. gs ('utt) : ('ertosa di P'esio, along the river, not nucommon (Noris); Cortina,

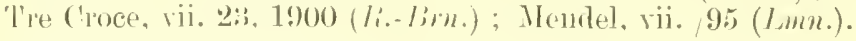

Directions of Yar. (a.) diminution of wh., leading to :

ab. \& Pythonissa, lilliwe (? fomd in nature).

L. Sibylla, L. (('amillit, Lisp.): 3 tsmmı. o 5 tmm. Frl. plt. honeysuckle.

Dist. Char. 111.s. h.w. ont. mareg. 2 rows of blk. spots on or. gret.

Loc. Sitater by firy to le fomnd gen. in the same locs. as ( mmillu. hut to he commoner, thomeh not monnting so high. In the

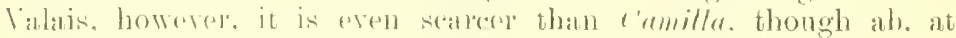

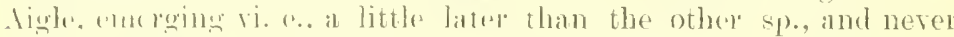

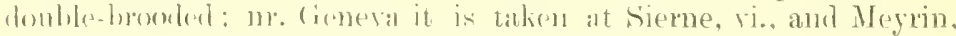

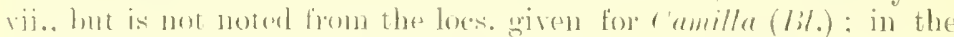

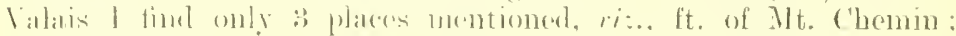

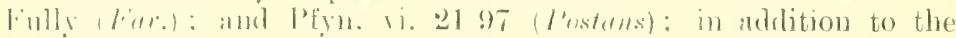

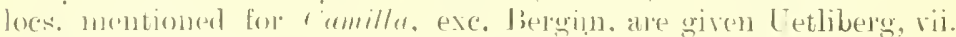

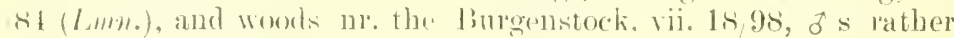

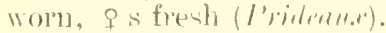

Celtosia rli Pesio, vii. and vii. l). 92. scatlec (Nm)is); neigrhbour. hood of Vinmua, vii. 97 (Miss fith.).

Directions of Var. (a.) diminution of wh.

ab. Angustata, St!l: : with narrower wh. band.

ab. Stænotænia, Hemuth: with band booken into separate spots. ab. Nigrina, II"ymer: which is withont the wh. band.

Genus, Neptis, Finln.

Prevailing col. blk.. with wh. nots and hands.

Dist. Char. short hroud wings.

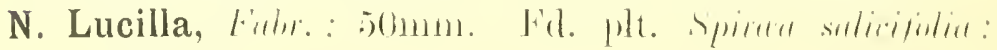
by). 1. 


f lilger than of.

Dist. Char. b.w. up. and mn.s. with only one wh. band.

Loc. Hedges and copses in the S. and S.F. (uot in the S. W.) of the region, vi.-vii. Jucarno, vi. l. 47 , a few (fomes) ; Ingano,

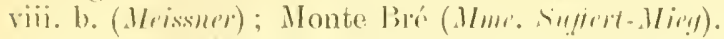

Susa, vi. 26 99, just emerging (li.-lirm.) ; Torre l'ellice, to right

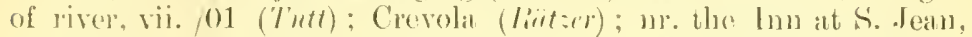

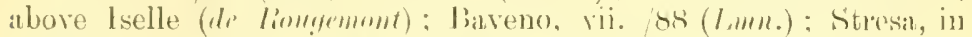
chestmut wood, vi. b. ST (Jomes): T'rol, e.t., 2 miles up the

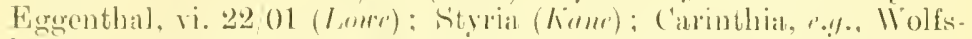
herer, vij. 1 s 97 (Lmm.) : Mönlling, vi. from larve fomd the prevons month in the part at Schönbrinn, Tiemua (Miss litu.).

\section{Fam. APATURIDE.}

Tribe ('HARкан11.

\section{Genus, Charaxes, (), hs.}

C. Jasius, /., (.Iasom. I..: Rhea, //\%,) : 70mm. Fd. plt. Arbutus: nnede: hyb. l.

o larger than of.

Dist. Char. 2 long tails m. anal ang. h.w.; grd. col. deep brn.

Loc. Only in $s$. of the Alpes Maritimes, Nice, Cannes, de. $(B r m$.$) : v. and viii.-ix.$

Directions of Var. (a.) size : $62 \mathrm{~mm}$. $-7 \mathrm{~s} m m$.

(b.) $11 m$ mher and size of bl, spots up.s. h.w.: sometimes almost obsolete, sometimes large, and reaching almost to disce. cell.

(c.) borly of $q$, esp. in 2nd brool, sometimes brick-reel.

(11.) ims. or. band up.s. f.w... in list hrood, sometimes much enlarged and lengtluened. reaching to b.w.

(e.) shatpe of $w$. diflering in the 2 brooks. In the 1st broed the ang. mr. lower end of onter manrg. f.w. is much more mominent than in the 2nd, and the "tails" of h.w. incline towards each other, in the 2nd brool they are marly parallel, and lather slightor. atull longere.

1 am indebted to Mr. Powell for all my information on the valdia tion of this spe.

Tribe Apritu.

Genus, Apatura, linlm.: hrl. l. 
Prevailing col. blk.-brn., with wh. spots and bands.

A. Ilia, Schiff. (Tris, trip.) ; б 55mm., \& 68mm. Fd. plt. willows and poplars.

of witb, \& without, brilliant prp. reflections.

Dist. Char. un.s. h.w. pinkish, wedge-shaped band from costa, not gen. v. conspicuons, and withont external edging.

Loc. In Swit\%. gen. Aistributed in the cantons of Basle, Aargan, Kïirich, Berne, Nenchâtel, Thurgau, St. Gall, Glarus, Vand, but only in the lower parts, scarcely risiog above $3000 \mathrm{ft}$. $(F r y)$; r. ab. in the beech forests of Jura (hane); in E. Vand and the Valais it is searee, lont found oceasionally, e.y., Charpigny (Fis.); Aigle, vii. J01; Martigny, vii. 1900 (Wh.); Sion; St. Léonard; Granges; above 'l'urtmann (Far.); Pfyn, the W. side, vi. 21/97 (Postuns); the E. side, vii. $19 / 99$; vii. $13 / 01$, not v. fresb, c. (11'h.); nr. Geneva, Versoix, Veyrier, vii. (IS/.); Locarno (Fir.); Monte Bré (Christ); the lower Misox (Hivdure).

[Obs. - In the Valais and F. Vaud the tgpe is the usual form, elsewhere in Switz., esp. on the Jura van. c!lytie is more e.]

Aix-les-Bains, vii. e. 9s (T'uft) ; Digne, vi. $/ 90$ (Nicholsen); Alpes Maritimes, and liasses Alpes along streams, the type, and vars.

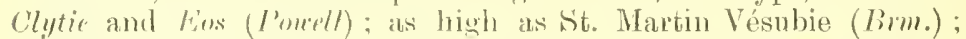
Cortosa di Pesio, var. (lytie, viii. /92, c. (Novris); Susa, viii. In. /97 (Tutt) ; vi. 26/99, some fresh, mostly much worn (R.-Brm.); Olgiate, viii. and ix. 95, and 9s (Miss litn.); Meran, /80 (Tutt). These dates point almost conclusively to a 2 nd brood in the $S$.

Directions of Var. (a.) loss of wh., culminating in:

ab. Iliades, Nitis; in which the wh. bands are almost unrepresented ( $v$. scarce).

(b.) Increase of tawny col. (in type, only round eye-spots and at aual ang.h.w.).

ab. (\& yar.) Clytie. Shrif. (Astalsir. //1.): in which it talies the place of wh.

ab. (\& yar.) Eos, liussi (Dilutior, Stur.; Budensis, Fnchs); in which it invales the whole snrface of the ws., esp. in $q$.

ab. Astasioïdes, Styr: : a tawny form corresponding to ab. Tliades (v. suprì), v. scarce.

(c.) absence of eye-spot at anal ang. h.w.

ab. Metis, Frr.

Loc. Alpes Haritiues (lirm.); ('ertosa di Pesio, below San Bartolomeo, viii. 30 (1) (Norris).

[Obs.- The \&, like tinat of lrit, seldom descends from the trees till towards 4 p.m. : the $\delta$ principally before 10 a.m., lut mal be found at other times on damp places in roads, or resting on any kind of garbage, though not to the same extent as the of Iris.

A. Iris, L.; o tomm., \& tismm. Fd. plt. sallow.

\& with. \& withont deep prp. reflutions. 


Dist. Char. un.s. h.w. large weelge-shaped wh. I and from costa, elged externally with chocolato col.

Loc. Gen. distributed in the same cantons as llia $\left(\gamma_{0}, \eta_{0}\right)$, and also Schafthausen; much commoner in F. Vaud, e.!., ab. between Aigle and Sepey, vii. 5/01, \&e. (I/h.); amd in the Grisons, Coire, Prïtigan, the Rhine Valley (Killias); sometimes at great heights, e.l.. top of the Rocher's de Naye (lis.), Nc.; emerges later than llia, vii.-viii., e.\%., Villemenve, viii. 9/01 (II\%.); sometimes, however, rather earlier, even at considerable elevations, 1 ./., I Iman, vi. $21 / 01$ (Stoper): ah. in the forests of the Inra np to $2800 \mathrm{ft}$. (linn').

Alpes Maritimos (limm.): Val Susia (Kane); Certosa di Pesio, a few in lower valley, vi. 92 (Nurris); Villach and Wolfsbere, vii. 97 (l, IIII.).

Directions of Yar. (a.) tendency of wh. to diminish, cuhninating in :

ab. Iole, sichif. (lierois, $F a b r$ ); in which only the apical spots rewain.

Loc. With type but v. scarce; Berne (Meissuer); Burchorf (M.-D.) : Liestal ((hrist) ; Alpes Maritimes (Brm.), \&c.

\section{Fam. LIBYTHE IDE.}

Genus, Libythea, Fabr.

Prevailing col. bru. with or. blotches.

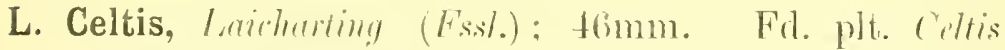
australis: hyb. im.

of rather larger than of .

Dist. Char. A projecting ang. on out. marg. f.w., h.w. concare on

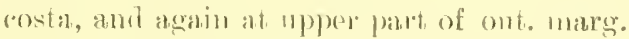

Loc. In Switz. confined to the S. From the village of Simplon down to (and beyourl) the frontier to laalf an hour above Crevola: at the village vii. $/ 97$ (I'iinfeler), but v. lancly so high up the Pass: Lugano, ir. 16/02, mostly worn (F'is.): ('hiasso, vi. $26 / 92$ (1/ayer) :

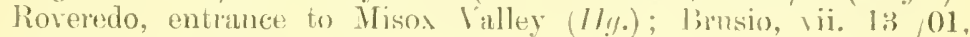
some v. fresh (Fis.).

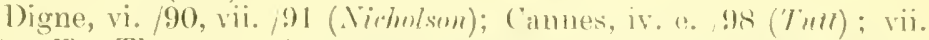

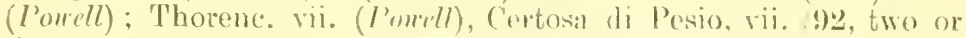
three only (Norris); Crevoli, vi. 39!9, fresh : r. 26, 1900, torn to shreds: Cal Anzasea, vi. 12 and ho 1900). fresly: Sarnthal and

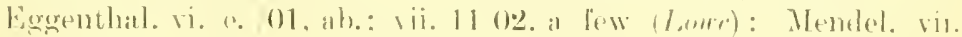

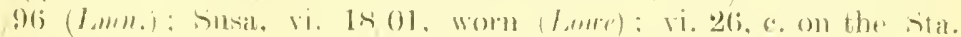
Waria road and alon on the left hank of the Doria molere the IIt.

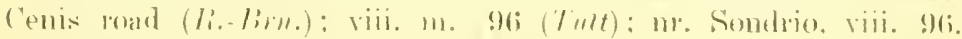
not e. (Miss Fitn.).

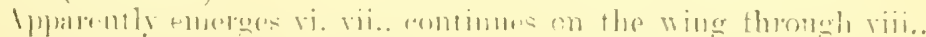

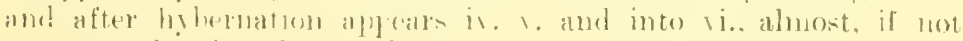
quite, orerlapping the new borst. 


\section{Fam. SATYRIDE.}

Sub.-Fam. SATYRINÆ.

Tribe Parariald.

Genus, Pararge, //h.: hyl.. I.

Dist. Char. mp.s. h.w.. a siris of eye-spots following out, marg.

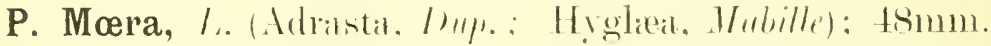

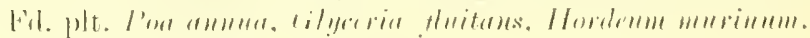
o lighter and brighter than o.

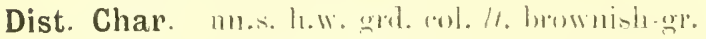

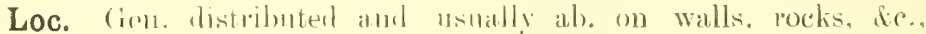
thronghomt ihe region, thomgh apparently wanting in certain Hatter

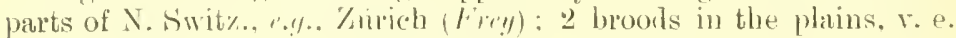

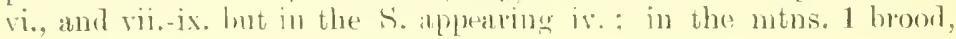
vi. e-riii.

Directions of Yar. (it.) sirt: at r. diminutive form abont the size of Tithour: of at the top of the Stelvio, vii. 13. 1900: a rather

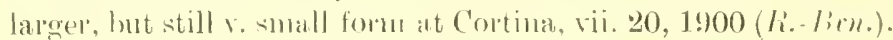
(h.) diminution of lulvous up.s.:

ab. Obscura, lint: mather below werage size; namow fnlvous ring round apical eye-spot and $r$. slight traces of 2 fulvous patches below, attendant apical eye-spots r. small, f.w.; narrow fillons marg. to eye-sjots h.w.

Loc. Aix-les-Baium, r. b. $97(+\% \mu)$.

ab. Monotonia, sthilde: in wh. it has almost, or entirely. disappeared (? o only).

(c.) increase of fulvous mp.s., culuninating in :

ab. (\& var.) Adrasta, 1/1. (Mura, lixp.): in wh. it is well. developed in is . and sulfures most of f.w. in $q$.

Ohs. - This is a form of the gad brood and is found with type in warm places (not gen. in " "old and elevated localulies" "as stated by lamg, though in the Alpes Maritimes it is taken at Sit. Martin Vésubie, and Boreon (Poctell). Digne, vi. e., and vii. all were of this var. (.Miss Fll.). Every intermediate form may be fomml.

(1.) number of eye-spots ap.s. L.w. (2.4, with tritces of a ith).

(e.) eye-spot up.... [.w.

(i.) a darge aprical eys-apot with one wh. pupil, with indieations of a small efe-spot abore.

(ii.) a 2mol wh. pupil to lange eve, with or withont a small one above, comspictums or ill-rlefined.

(iii.) this $2 m$ wh. pupil lnecommong alnost detached, with the blli. romed it, from the latge one : and (iv.):

ab. Triops, fwhe: "large aptical (") " with 2 pupils, a well defined small one above, and another large single-pnpilled eye in the

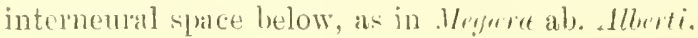






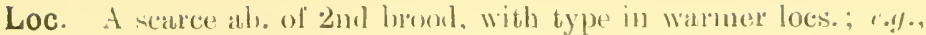
digle. viii. (?. $1900(11 \%$.).

P. Hiera, Fulle: $4101 m$. Fil. plt. Fisturn and other criasses.

? lighter and brighter than o .

Dist. Char. un.s. h.w. dli, wrevish-hrn. (gen, with small lt. patch (on costit).

Loc. In a few places in the lowlants; ft. of the Uetliberg (Frey): the Glarms Valley (/ $/ \mathrm{rer})$; but more usmally in the lower Alps and in some places up to 6000ft. 'Lhe Rigi (Smll); Oberlasli (Kime); Thalalp; Kupfemaseruns ahove Filzbach, vi. 1!)/02 (lis.);

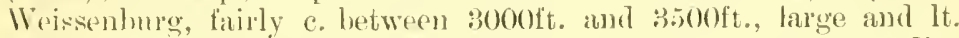
$(/ / y$.$) ; the Jura, e./., St. Cieorwes, vi. e. (1), v. Jarge and dk.$ retting worn (1/\%); (myre on the right bank of the Sarine, viii. 3097 (li.-lim. $)$; on most of the mins. on both sides of the Rhone Valley, e.\%., Rocher's de Naye, Dent de Morcles (Fis.); on the latter.

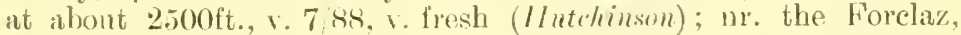
esp. on the roud leating to the 'Trient glacier': Nionc, Snsillon, Ponchette, Chandolin, in the Val A'Anniviers: Loeche-les-bains: Zerumate: Gondo, \&e. (l'ar.) ; Tirisal, ab., sumall and dk., over by vi. m. 99, but less worn vii. !) 01 ( $11 \%$.) : Weissenstein in the Grisons ( $/ / 1 l$.$) : Maloya, vii. Sis (l,mi.).$

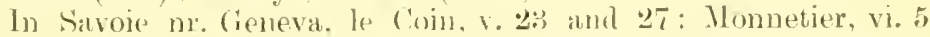

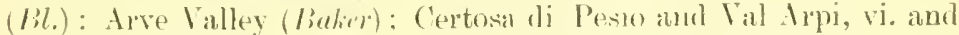
viii. (. 92 (a few) (Vomis); Larche (Kame): Val Anzasea, vi. $7 / 87$

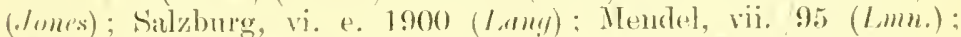

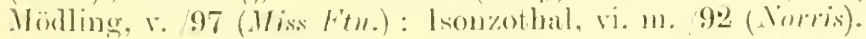

Ohs. Gen. 2 broods, r.b.-vi.: and viii.. but sometimes onls 1, e../., Bérisal. where the lst brood is e. but 1 have neser seen a single specimen of a 2 nd brook, thongh l have often hunten them in lugus.

Directions of Var. (a.) size : :

(b.) brightmess of grid. col. "1).s.

(c.) (ye-sjuts up.s. f.w. : simle range of vall. as . Hora (1\%.1.). exe. that tho domble wh. pupil in an entirely mnbroben blk. spot is mmsmal. and that there is frepuently (6.)., in the fura specimens) an indication of the extra eye in the internenral spare next below the laree eye-spot. This culnminates in:

ab. Trinoculata, $\| \%$ : in wh. it is well developed.

(d.) depth of und. col. m1.s. h.w. (the eyespots are less conspicnons on alk. grit.). (e) number of "ye-spots up.s. h.w. (:-5) .

P. Megæra, L. (Niphia, lisdr.) : tomm. Fid. plt. Hor"lemm mmimm and other arasses.

a with, o withont ak. brn. har up.s. f.w. slanting inwards from centre of 1 . towards inm. Harge. 
Dist. Char. up.s. gred. col. brt. or.-brn.

Loc. Gen, distrilnterl, and c., but scarcely to be seen above $4500 \mathrm{ft}$;

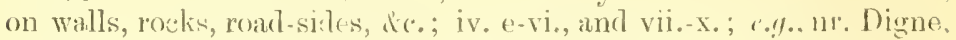
x. 18,02, v. fresh (li,-lim. ) perhaps a $3 \mathrm{l}^{\circ} \mathrm{t}$ brook.

Directions of Yar. (al.) subsidiary eye-spots up.s. f.w.

(i.) often a small one above the large one, and nearer apex:

(ii.) rarely snother small one below and outside; sometimes attached to the large one:

(iii.) an indication of a spot in the next interneural space, culminating in :

ab. Alberti, Redlich ; in which it is well developed and wh.pupilled.

Loc. In the warmer loes. with type, but gen. scarce in Switz. Martigny, v. e. $/ 01$ (Sloper) ; vi. m./0: (Wh.) ; above Branson; Saillon (Fan.) ; Sierre, v.m./03 (Sloper) ; Charpigny, v. 15/01, \&c., and transitional forms ( $F$ is.); a fairly well-marlied form c. in $f$, scarce in $\approx$, Aigle, and elsewhere in Rhone Valley, v. m. to vi. $\mathrm{m}$. 103 (Wh.).

By no means scarce in S. W. colner of the region, e.y., iv. 15, 18, 21, \&c., os and $\left.q(S l o p e)^{\circ}\right)$.

(b.) darkening of np.s.

ab. Mediolugens, Fulks ; a scarce ab., with el. area of f.w. blk.

ab. (in W. Asia, var.) Transcaspica, Styr.: in wh. the base, inn. marg. and v. broal ont. margl. border f.w., and almost the whole h.w. are ak. hen.

Loc. Losone, nr. Locarno, iv. 25/02, a magnificent के (Fis.).

(c.) lighter and greyer grd. col. un.s., culminating in :

ab. (in S.-E. Europe, var.) Lyssa, Bsdr.; [a transitional form closely approximating is not scarce in the hotter parts of the Rhone valley in the 2nd brood, esp. at Salquenen and Varen $(M .-1))$.

(d.) number of eye-spots np.s. h.w.; normally 4 , exceptionally $3-7$.

\section{*P. Egeria, I. (Meone, Esp.); 40mm. 'Fd. plt. Triticum repens, I'oa pratensis, dic. \\ o rather lighter and with larger spots than $\delta$.}

Dist. Char. up.s. dk. srel. col. with fulvous or ochreous spots.

Loc. Distributer throughout the region in one or other form. and c., in woods and copses, but not gen. above $3000 \mathrm{ft}$. The type, deep brn. grd. col. and brt. fulvous markings, is only found in the $\mathrm{S}$. of the region, Basses Alpes, Alpes Maritimes, and on the $\mathrm{S}$. slopes of the more central Alps; Val di Vedro ( 1 ar.), \&c.

[Obs.-This is one of the earliest and latest of the butterflies that do not hybermate as imago. It has $;$ or even 4 broods, and emerges in the S. as early as iii. b. (e.1., iii. 4/02, Sloper), and sometimes as late as xi. (Tutt).] 


Directions of Yar. (i..) depth. of col. up.s., gradually paling in spots, deepening in wred. col.

var. Intermedia, 'Tutt: "fuscons hrn. with pale fulvons unarkings."

Loc. 'The usmal form in the warmer parts of the Valais; also on the B. slopes of the oluris, ile.

[Obs.-This according to Frey is var. Meone, Esp; if this is correct Intermediu must fall before Heone.」

yar. Egerides, Styr.; dk. fuscous with pale yell. markings.

Loc. The nsinal form in the less warm part of the region. It must, however, be inderstood that every intermediate shade exists, and that no bard and fast line cin be drawn.

ab. Pallida, Tutt: with whitish inarkings.

(b.) number of eye-spots un.s. h.w.; 3-6, gent. 4 or 5 .

(c.) extent of prp. suffusion un.s. b.w. [T'his is gen. in proportion to the col. IIp.s., there being most in type, and least, often none, in Eigericles.]

[Obs.-In Mr. Fison's collection is a specimen, from Luecus, with no lt. spots on basal balf of f.w. and no lt. band on. h.w.]

\section{P. Achine, Scopoli (Deianira, I..) ; 50mm. Fil. plt.} Lolium perenne, Poa annua, and other grasses.

Up.s. f.w., it. mark from nr. centre of costa more marked in $q$ than in $\sigma^{\pi}$.

Dist. Char. series of large eye-spots on f. and h.w. up. and un.s., unpupilled on up.s., those on mos. h.w. placed in a conspicuons wh. band.

Loc. Local, and preferring damp, shady woods, vi. e. and vii. Neighhourhood of lasle, e.\%., Liestal, Iftenthal, \&c. (1./hist); the Bechlourg (K...s.); Canton of Aargau (Meissure); Schafobusen (Tralm); Uetliberg, vii. 13/s.5, \&c. (Lmn.); Canton of St. Gall, but searce (Täshler); Gliurus (Her); Lingern; Aarberg; Worb); Lake of Bienne (1L.-L).); Lattrigen, vi. P?) (Tutt); Nenveville (I'ouleru); the pine woods of the Dôle, ab. (liakler); liois de Voyrier, vi. 24; Bois de Bay, vi. 21 and 26 ; Hermance, vi. 25; Onex, vii. 11 (Iil.); Veytanx, vi. 13/97 and /99, scarce; Aigle, vii. /01, ab. (II/.); thence to Sépey, vii. 2/98 (. Imoss); Bex; Martignny (Far.).

Mendel, vii. 95 (Lmu.); Pejo, vii. 95 ( $(\mathrm{h} / \mathrm{L}$.$) ; Berchtesgaden, vi.$ 27,1900 (Lan!y).

Directions of Yar. (a.) 11 n.s. h.w. presence or absence of a small eye-spot immediately above the 3rd from anal ang.

(b.) number of eye-spots un.s. f.w. containing wh. pupils.

[In all examples I have seen the lowest is pupilled and the next blind: the others vary. 
Tribe SaTYmin.

Genus, Satyrus, lıtr. Fil. plt. glasses: hyl. l. Prevailing col. v, dk. lom.

\section{S. Hermione, I. (Hermione major, Esp.): $70 \mathrm{~mm}$.}

o with much more conspicuons band up.s. than $\delta$.

Dist. Char. Unintermuted hand extending across f. and h.w. up.s.

Loc. [1 have given the locs. as I find them recorded for Hermiom and Alryom respectively, but with regard to the Swiss forms, esp. those of the Jura, Vaud, and the Valais, r. infri. Basle: Liestal (( hrist): Selatfhansen, c. (Tropp): ()lelutzwyl

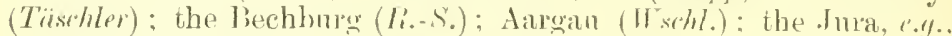
nr. Basle (christ); alove Nenchatel, viii. 26; v. worn (li.-lim.): Vallorbe, viii. !), de. (12, rather worn (ITh.): St. Cerones, vii. 20 (Bl.); thronghout Vand and the Valais. r..., Lausanne (1/.-1).); above Montrenx, viii. $59(;$ (ho-lim. ); Ainle, and thence to sépey, ง.ab., vi. e.-viii. un. (H\%.); Nartigny, vi. 14/01 (Slou'v); all along the Rhone Valley and the lateral valleys $\left(F^{\prime}\left(r_{\circ}\right)\right.$; on the Simplon Road up to the Ith Refnge (its extreme altitude, l think), vii. m. 98 , v. ab., usually $\mathrm{v}$. worn by viii. $1 \mathrm{~m}$. ( $11 \%$ ) ; in the Grisons only in the 3 S. Valleys, Misox, Forgell, and Poschiavo (Fry) : Ingano $($ R.-S.) : San Stefano, vi. 29 ( $1 /$ ay/er).

Mt. de Sion, nr. (ieneva, vii. $20($ I l. ) : Sc.; thronghout the S. alpine valleys of France. X. Italy, the 'Tyrol, \&c.

Directions of Var. (a.) decresse in size, crlminating in :

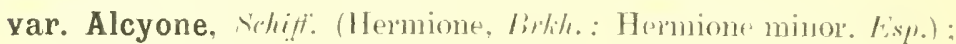
$55 \mathrm{~m} 11 .-5 \mathrm{~s} m \mathrm{n}$.

[Obs.--After much enresponlenee and the comparison of many specimens from varions loes. I feel convinced, esp. as there is nothing v. distinctive in the earlier stages, that flcyon is merely the extreme form in one direction of the same sp. of wh. Hermione from the liviera is the other extreme. It wonld he easy to form a series in wh. each insect would scarcely differ from those on each side of it, but the extremes of wh. should be the nost pronounced forms of Hermione and Alryone. In districts whele both are found, as on the Riviera, they are distinct enough, and the separtion into $2 \mathrm{sp}$. may be almost complete, Hermione inhabiting the lowlands, Alcyom also the higher ged.; Hermiome resting on trew trunks, Alsyome on rocks; the lt. band of Alcyone, up.s., being narrower and more suffused than in Ilermime, de., but in Vand and the Valais, the specimens are intermediate in size, markings and habitat, and on one side of the Aigle valley rest ehiefly on trees, on the other side on zocks. None of the usmal distintions hold goorl in the average Swiss specimens. To take a few links in the chain the following are representative:(i.) Hermione from the Riviera; (ii.) Hermione from S. Grisons; (iii.) Hermione, so-called, from the fura; (iv.) Hernione, so-called, from the Rhone Valley; (v.) Aleyone from the Riviera; (vi.) Aleyone from Saxony. Frey treats both ats one sp.]

Loc. The Rechburg (li.-S.): Veyrier, vii. 13; viii. 3 and 21 (Bl.) : singly tluronghont the Rhone Valley $(F a r$.$) ; i.e., specimens$ wh. more nearly approach typical Alrymo: nr. Fiesch, 2/\$5: Piérisal, vii. $30 / 97$, de. (li.-Bim.).

Bourg St. Mamice, viii. h. /98; St. Michel-de-Mamienne, vii. e.

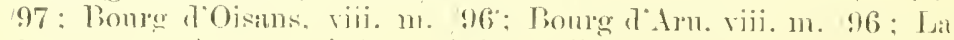

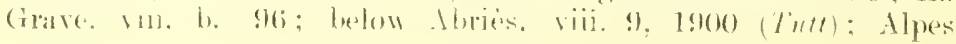




Maritimes, from sea level to $5000 \mathrm{ft}$ ( Porrll); above Boblie, viii. m. 01 ('Thtt); Stelvio, below Spondlinig, rii. 1702 (li.-lim.); Mäilling and Baden nr. Viemna, viii. 97 (Miss Fin.).

(b.) greater or less amount of smoky suffusion over lt. band in $\delta$.

(c.) greater or less amount of mottling on lt. band min.s. h.w.; sometimes, esp. in Herminim from the S., almost obliterating the band.

(d.) greater or: less amount of mottling on base, wn.s. h.w.

(e.) frequently a 2 nd spot on lt. band f.w. 111. and Inn.s. of, as in $q$.

\section{S. Circe, lislur. (Proserpina, Sirliti.); $70 \mathrm{~mm}$.}

o larger than $\delta$.

Dist. Char. wh. land up.s. f.w. and h.w., broken on f.w. below apical spot.

Loc. In Switz., only in the W. and in the S. of the Grisons ; vii. m., viii.; in the Canton of Berme, between the Obertand and the Jura, c. at Aarberg, Schimpen, Burgdorf (Frry); lierne

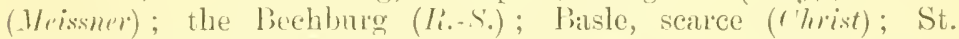

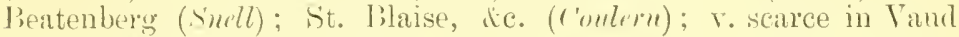
and the Talais: St. ('ergmes, viii. 4. (13l.); Glion, vii. \& 01 (Sloner); Mt. Pélérin, viii. 3001 (Keyres); c. in the neighbourhoorl of Vevey and Montreux, vii.-viii., 01, though not seen in the district for many years previonsly, and scarce since; between Aigle and sipey; between Visp and Zermatt (Tuslien): Versoix, viii. (Iil.).

Wuch commoner further S.: Digne, vii. 99 (1/iss litm.) ; Anuot, rii. 1799, v. c. (Lan!l); Vallon Obscur, St. Martin Vésinbie, de. ( $\mathrm{Brm}$.$) : La Bocea, Cannes, vii. 13-1691, c. (Nirholsm) ; ('ertosa di$ Pesio, anong chestmut trees above Chiusa, vii. viii. 92 (Norris): Val Muerta, x. 9.02 (li.-lim.); liaden, nr. Tiema, viii. 97 (Wiss lith.).

Directions of Var. (a.) dininished brealth of wh. lamd up.s., esp. f.w., culminating in :

(. :) ab. Silenus, sty $r$; which has no wh. bands.

(b.) a 2nil spot just below centre of band f.x.

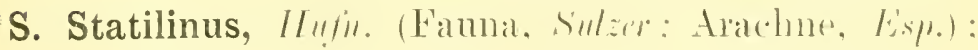
$46 m m$.

o with more traces of lt. band np.s., esp. f.w., than $\delta$.

Dist. Char. up.s. f.w. 2 eye-spots with 2 wh. spots between them; un.s. h.w. dk. edge of basal half not jutting in long sharp ang. into lighter band.

Loc. MLtns. of Alpes Maritimes, vii.-viii. (I'ormll); Certosa di 
Pesio, at and above Chiusa, viii. 14. \&c. 92 (Noris) ; Botzen, vii. 18,1900 (R.-lim.).

Directions of Var. (a.) increase of size:

yar. Allionia, Fabr. (Fauna, Hb.; Fauna Var., Fsp. ; var. Martiani, 11.-S.) ; 5 tmm., and with base un.s. gr. instead of bru.

Loc. In Switz. only from Martigny to Prig (or a mile or two on each side); v. ab. at Follaterre and the 'lom de la Bâtiaz, e.\%., viii. 21 , ix. $1 / 99$; viii. 27,1900 ; also Sierre, viii. $18 / 99$; Brig, ix. $7 / 98$ (Wh.), \&c. ; also at Lugano (H!).).

Susa, viii. 1n. $/ 97$; Aosta, viii. m. $/ 94$ (Tutt); in the lower parts of the Alpes Maritines (I'orell).

(b.) absence of pupils in the eye-spots; in both on f.w. up.s., and in the lower one on un.s. $\delta$, and in the latter on both sides in $q$; also in the small one at anal ang. h.w. on both sides, $\delta$ and $q$; v. usually.

(c.) up.s. h.w. wh. spots (1-4), forming antemargl. row above eye-spot at anal ang. (as in Fillia).

(d.) traces of same wh. spots un.s.

(e.) amount of mottling un.s. h.w.; sometimes almost unicolorous in $\varsubsetneqq$ (as in Fatua).

(f.) amount of angulation in dk. el. line, sometimes approaching Fillia.

(g.) anount of yell. band in $q$, f. and h.w. up.s. and f.w. un.s.

CObs.-This insect in the Rhone Valley varies so much in detail, and approaches so closely to Fidia and Futua, that I feel some doubt whether all are not local races of the same sp.]

S. Fidia, $L_{\text {. }} ; 56 \mathrm{mmm}$.

ㅇ larger than $\tilde{\sigma}$, and with more conspicuous markings.

Dist. Char. up.s. f.w. with 2 eye-spots, and 2 wh. spots between then: un.s. h.w. with dk. cl. line jutting in the middle into the lt. band in a long sharp ang.

Loc. Digne, vii. m. 98, not c. and difficult to obtain (R.-Bm.); Levens; St. Martin Vésubie (I'omell); Spondinig, viii. 18, 1900 (Ii.-Iim.)

Directions of Yar. (a.) diminution in size, culninating in :

ab. Monticola, Thim?-Mie! : wh. is also darker.

S. Actæa, lisp.; $48 \mathrm{~mm}$.

o with a 2 nd eye-spot up.s. f.w. and traces of a band. 

Dist. Char. one wh.-centred apical spot in $\delta$, on $r$. dk. unicolorous gred. ( o r itymit).

Loc. Digne, vii. 99 (li.-lim.); fairly c. in dry places on limestone in the Basses Alpes and Alpes Maritimes, vi.-vii., 'Thorenc, dc. (Iourll) ; Susa, vi. 27 99, just emerging (Ti.-l;m.) ; Campiglio, rii. 95; Innsbruck, vii. 97 (Lmm.).

[Obs. - I agree with MIr. Nicholson that the fact that cordula is c. rather earlicr in the season, on the same banks at Digne on wh. Actor is ah. vii. e., is conchusive as to their being 2 distinct sp.; I have therefore treated them as such.」

\section{S. Cordula, Frellr. (Hipporlice, H/\%.); 52mm.}

o with distinct lighter band, up.s., esp. f.w.

Dist. Char. at least 2 wh.-centred eye-spots up.s. f.w. in o , and 3 or more in 9 , on $\mathrm{v}$. dk. grot.

Loc. Gen. c. and often ab. in the Rhone Valley from digle to Bricr, and thence in small numbers to the Rhone Glacier, also in the S. side valleys from the Val d'Hérens to the Simplon and at Loeche-les-bains ( $/ a r$.$) ; r. ab. on the roar from digle to sépey, rii.$ and viii. 01, de., the of s. with $t$ wh. spots at the lower elevations, and 2 higher up; (riornico and Cresciano (Traph) ; Brusio (c'a/lisch).

Jbourg St. Maurice, vii. e. 9s; St. Michel-de-Maurienne, vii. e. 97; La Grave, viii. m. 96 ; Bourg d'Oisans, viii. m. 96; Larche to Pincelonette, viii. b. 1900; Abriès, viii. m. 1900 ('l'utt) ; Digne, vii. ()), c. (Li.-li’n.) ; St. Martio Vésubie, \&c. (lim.); Annot, 'Thorenc (Ponell) ; Pré St. Dirlier, viii. b. 98 ; Cogne Valley, viii. 8.94; Susa, viii. nı. 97 (T'utt) ; Orta, vi. In. 1900) Botzen, vi. (. 01 (Low )

\section{Directions of Yar. (a.) size: 4 Simm.-5smm.}

(b.) number of eye-spots up.s. f.w.; 2-4, rarely $: 3$, in $\delta$, occasionally a ith minute one nearer apex; 1 in $q$, sometimes forming a bant.

(c.) depth of grot. col. esp. in $\vec{b}$, varying from nearly blk. to sooty-brir.

(d.) extent and depth of col. of band up.s. in $f$, varying from dull or.-brn. to pale ochreous, sometimes scarcely visible, sometimes forming a conspicuous band f. and h.w., the extreme form being :

ab. ? Pœas, /lb. : wh. is also lighter un.s.

(e.) eye-spots (or blk. (lots) h.w., gen. 1 up.s., 2 un.s. in of; 2 up. and tur.s. in $q$; but sometimes absent, and in $q$ sometimes 3 up.s.

(f.) more or less distinctness in band un.s. h.w. 
(g.) lightening of col. un.s. h.w., culminating in :

ab. Bryce, $/ / b$. : in wh. they are whitish and almost unicolorous.

Loc. Not uncommon at Ponrg d'Oisans, riii. m./96 (Tutt).

Genus, Enodia, $H /$.

E. Dryas, Sicopoli (Phoedra, L.; Briseis, Esp. ; Athene, Bril. $) ; 52 \mathrm{~mm}$. Fd. plt. grasses; hyh. l.

\& lighter and with more conspicuons eye-spots than $\delta$; gen. larger.

Dist. Char. up.s. f.w. 2 blk. eye-spots with $\mu m$. centres on $d k$. brn. grd. col.

Loc. Sasle; Zürich, nr. the Trichtenshans Mill (Snll); Goldan (Yll.-Dolder); round St. Gall and in the Toggenburg (Trischler); nr. the Lake of Thun, e.\%., Gunten; Aarberg and Worb (Fry); the Jura (Jit!li), e.\%., St. Blaise and Nenveville (Fry); Meissenburg, in marshes (H\%) ; Sierne, viii. 3; Yersoix, viii. 18 (1/l.) ; Aigle, v. ab., riii. m.-e., 1900 ; between Chillon and Villenenve, viii. 01 , ab. $(I I \%)$ ) : the Rhone Valley, from Martigny to Fiesch (Fur.); $\%$, , the Pfynwald, viii. b. 99, ab. (T/\%.); Lucerne, viii. 95 (Tutt); the

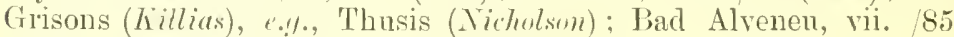
(Lmn.) ; San Stefano, viii. 7 (Jayer).

Charoire, rii. e. 02 ; Grésy-sur-Aix, viii. e., 1900, צ. ab.; above Lac Bourget, viii. e. 94, v. ab., but not fully out, vii. 2596 (Tutt); Digne; St. Martin Vésubie (Porrll); Venanson, v. ab. on Nice roar, .5:) kilomètres from Nice ( $\mathrm{Br}$..$)$; Lago di Loppio, rii. 31,1900, v. c., but worn (.Imis).

Directions of Yar. (a.) size: r. rariable. My smallest is $47 \mathrm{~mm}$., my largest $62 \mathrm{~mm}$., both o s.

(b.) tepth of grol. col. up.s., esp. in $\delta$.

(c.) col. of un.s. h.w. esp. in $q$ : in wh. it varies from dk. to golden brn.

(i.) loss of distinetness in markings un.s. h.w., culminating in :

ab. (in Asia var.) Sibirica, Sttr.: in wh. they are unicolorous, $\delta$ and $?$.

Tribe Tipparchint.

Genus, Hipparchia, Fiulır.

Prevailing col. brn. Fd. plt. grasses; hyb. l.

Dist. Char. a broken macular band f.w. and h.w. up.s.; yen. 2 eye-spots f.r. and 1 h.w.

H. Briseis, I. (Tanthe major, Esp.: Ianthe minor. bik\%.); $52 \mathrm{~mm}$. 


Dist. Char. band whitish ; $111 . .$. h.w. 2 dk. blotelese nr. basc.

Loc. In Swit\%., chietly on the Jura, e.\%., nr. Basle ( $/$ hrist); the lochburg (R.-S.); Bienne (1/.-1).); Bözingen (licnteli); St. Cergnes, viii. 29 (Bl.); r. scarce in the Valais; Mt. Ravoire, vii. m. ()2 (Ischl.); Naters (Far.); c. round (ieneva, e.\%., Veyrier, viii. s (lil.); Val Bregaglia (.Mentelbir).

C. in Saroie, r.\%. Annécy (l'is.); Grésy-sul-Aix, viii. e. 91 ; vii. 2.5 96, just appearing, viii. 19, 1900, e. (Tutt) ; Monnetier, viii. 10, v. large; Bossey, viii. :3 ;e Coin, viii. 16; Mornex, viii. $2 t$ and 31 (lil.); Barcelonette, viii.b. 1900, small (Tutt) ; c. at Digne in dry stony places, esp. towards the Dourbes, vii. 19-29/91 (Nichlsen); vii.

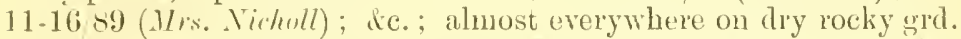
in the Alpes Naritimes, vii. viii. (l'orell); Spondinig, vii. 1702 (li.-lim.n); Mö̈lling, viii. 97 (MLiss l'tn.).

Directions of Var. (a.) increase of size, culminating in:

ab. Major, ()th.: with broader lt. band, esp. h.w.

(b.) col. of band up.s.

ab. Pirata, lisp.: with smoky reddish-yell. band.

Loc. The French Alps.

\section{H. Semele, $I_{\iota}$; $50 \mathrm{~mm}$.}

o larger, and with far more conspicuous and lighter markings up.s. f.w. than $\delta$.

Dist. Char. up.S., band ochreous (often indistinct in $\delta$, esp. f.w.); un.s. h.w. dk. cl. line much waved and angulated (often forming a profile).

Loc. Basle; Aarberg; Jurgdorf (Fry); St. Ciall, scarce

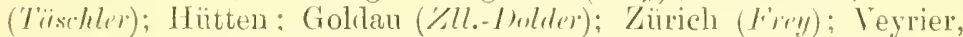
NC., vii., c. (IBl.) ; c. on the Jura, also in the cantons of Vand, the Valais and the Grisons, exc. in the mper Eugadine and the upper purt of the Val Bregaglia; Chiasso, vi. e.-vii. b. (1/ayer); (inarda, vii. e. $1900(\mathrm{r} / \mathrm{s})$; found up to $6000 \mathrm{ft}$, vi. e.-ix., according to latitude and elevation.

Gen. distributed through the rest of the region, r.4., Grisy-surdix, viii. 111. 1900 ; St. Michel-(le-Naureme, vii. e. 9T: Petit St. bernard, vii. e. 94; La (irare, vili. 11. 95; Abries, de., viin. in. 1900, $3 \mathrm{~s}$ r. dk.; La Thuile, viii. b. 98 ; L'ró St. l)idier, viii.b. 98; liobbie, viii. m. 01 ; Susa, viii. 111. 96, n11.s. h.w., oै with wh. band, of covered with gr' marbling ('lutt); Digne, vi. 90; vii. 91 (Lın.); Alpes Maritimes (L $\mathrm{mm}$.$) ; Cindenabbia, vii. st (Lım.):$ the Tyrol, e.\%. Mentel, vii. 95 (Lmm.), Campiglio, vii. m. 95 $\left(\mathrm{C}^{\prime} \mathrm{h} \mathrm{p} \cdot \mathrm{.}\right)$, itc.

Directions of Yar. (a.) col. of bant.

ab. \& Suffusa. 'Tntt: in wh. the band is scarcely visible f.w., and consists of 4 or. spots h.w.

var. Aristæus, Romelli (Semele, Mb.); with large reddish-or. band, of large size.

Loc. The more ustal form of the S.; not uncommon as ab. in 
the Valais; the more usual form at liérisal, vii. 98, lut not viii. 97. The form of the $q$ only at Susa, viii. m. 96 ('Tutt), de.

ab. Pallidor, Tutt; with pale straw-col. band.

CObs. - The name was originally (13ritish Butterfies, p. 300) applied to the \& only, but the $z$ of the cl. Jura, and some other place? has a broad pale band f. and h.w., and to this I have rentured to extend the name.] Vallorbe, viii. b. 102 ( $\mathrm{H} /$.) ; Obergurnigel (Frey).

(b.) distinctness of lt. band un.s. h.w.

(c.) eye-spots, up.s. f.w.

ab. o Craca, Tutt: in wh. they are unpupilled.

ab. Addenda, T'utt: in wh. extra spots appear in the band.

\section{H. Arethusa, lisp. : $44 \mathrm{~mm}$.}

o rather larger and with more pronounced band than $\tilde{\sigma}$.

Dist. Char. up.s. band tawny; un.s.h.w. dk. cl. line not angulated in the middle.

Loc. Reported from Val d'Anniviers (Hennet).

Grésy-sur-Aix, viii. m. 97; above Lac liourget, on rough grd., vili. 22, 1!00, ab. (Tutt); Digne, vii. 91 (Lmm.); on dry hills liasses Alpes and Alpes Naritimes, vii.-viii. b.; Castellane, \&c. (l'owrll) ; Susa, viii. m. 97 (T'utt); S. Tyı。 (Spmler).

Directions of Yar. (a.) col. of band up.s.

ab. Obsoleta, II h.; with band scarcely visible.

var. Erythia, Hh.: with tawny band redder and more pronounced.

var. Boabdil, limbr. : band and grd. col. darker; larger; v. distinctly markerl fringe.

Loc. Susa (Kant); Grésy-sur-dix (Tutt).

(b.) distinctness of 1 t. cl. band in.s. h.w. culminating in :

var. Dentata, styl. : with wh. neuration and band, and blackish dentate line letween band and out. marg.

Loc. A v. usual form in S. France; Grésy-sur-Aix, viii. m. 97; between Barcelonette and I'runicles, viii. b. 1900 ('I'utt); Digne (l'orell); Alpes Maritimes (lim.).

Sub-Fam. IPINEPHILINA.

Tribe EPINEPIHLIDI.

Genus, Epinephile, $/ / \%$.

Prevailing col. bru. and tawny-or. Fd. plt. grasses: hyb. 1.

Dist. Char. borters of all ws. dk. brn.; gen. followed, at least on f.w. by or. (r. slightly represented in . Iutina ठ and Lycam ठ).

E. Jurtina, I. (Janira, L.: Pamphilus, / Infu.; Hyper-

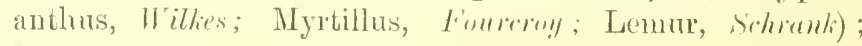
4511210. 


1)k. brn., o without, \& with conspicuous or.-bru. patch up.s. f.w.

Dist. Char. f.w. up. and un.s. blk. apical spot with one wh. pupil.

Loc. Gen. ab. in meadows, grassy road-siles, open woods, ic., mounting to about $4000 \mathrm{ft}$, and somewhat higher in the S. Alps; vi.-viii. e.

Directions of Yar. (a.) col, of up.s.

ab. उ Suffusa, Tutt: without trace of or. even round eye-spot.

ab. \& Pallens, Thirry-Mieg: or. replaced by pale yell.

ab. Semi-alba, liruand: the dk. col. giving place to pale whitish br'n.

ab. Brigitta, L.jmyh : an extreme lorm of above, in wh. all the ws. are of the pale tint, with reddish base and inn. marg.

yar. Hispulla, $/ / b$. : with more or. f.w. $\delta$, and with or. disc f.w. and with a partial or. band h.w. $q$; larger than type.

Loc. The regular form in the S.; an intermediate form occurs in the Valais and other hot locs., becoming var. Hispulla in the S. Grisons.

(b.) col. of un.s. h.w. ․ At Aigle it has a range of col. in the lt. band (wh. is normally ochreous), corresponding with that of E. Ethiops:

ab. $\&$ Grisea, Tutt; with gr. band.

ab. + Yiolacea, Wh.; with band strongly tinted witl heliotrope.

(c.) number of blk. dots un.s. h.w., 0-5 ; normally 2 ; sometimes dereloper into ocellated spots, e.\%, Gimel, vi. 2703 (II\%.).

(d.) sometimes a small spot f.w., esp. un.s., attached below apical spot, occasionally showing a 2nd wh. pupil.

(e.) occasional traces of additional eye-spots f.w.:

ab. Erymanthea, F.sp. (Addenda, Monsly); v. rare.

E. Lycaon, liutl. (Eudora, Lsp.); 3smm.

1)k. yell.-brn.; of without, o with conspicuous or.-bru. dise and lighter ante-margl. band f.w.

Dist. Char. f.w. up. and un.s. apical eye mmprilled.

Loc. St. (iall (Tirshter); Schaffhausen ('Trey') : Lostorf, scarce (Strhlih-Imhoti) ; Jura, Bienne and Neureville (H.-/).); v. c. ju the warmer parts of the Valais fiom Martigny and Follaterve to Huteggen and Bérisal, vii.-riii. (1'at.); e.\%, Sierte, ni. 9!); Bérisal, vii. 1301 ; vili. m. 97 , of s woln, of still good (II\%.); Saas, vii. e. \$5, c. (Jones) ; St. Nicholas, vii. 23, 1900 (likm.); 
Súpey road, above Aigle, vii. 11.01 ( $11 \%$.) ; lower Engadin, Zernetz (Schmh) ; liergell (hillias).

Bossey, vii. 25; viii. $2-15$ (/ll.) ; Glésy-sur-Aix, viii. m. 1900 ; Bourg St. Maurice, vii. e. 94; St. Michel-de-Manrienne, vii. e. $/ 97$; Bourg d'Oisans, viii. m. 96; Larche, vii. e. 1200 ; Barcelonette, viii. b. 1900 ; Abries, viii. 11. 1500 (Tutt) ; Digne, vii. 91 (Lmm.) ; c. in mtns. of Jasses Alpes, and. Alpes Maritimes, but not occurling nr. coast, r.-viii., r.!., Jeauvézer, Allos (Purcll) ; Courmayeur, viii. 594; Pré St. Didier, viii. l). 98; Cogne Valley, viii. m. 94; Bobhie, viii. m. 01, v. scarce ('Thtt); Macugnaga, vii. m. 1900 $\left({ }^{\prime} / \mu^{\prime}\right)$; Certosa di I'esio, vii. 30, 92, v. ab., $2800 \mathrm{ft} .4500 \mathrm{ft}$. (Nomis): 'Tyrol, Mendel, \&c., vii. 95 dc., (Imm.).

Directions of Yar. (a.) up.s. shade of grd. col., and extent of traces of or.-brn. in $\delta$.

(b.) up.s. f.w., shade of or.-brn. on disc, $q$, making lt. band more or less conspicuous.

(c.) ठ, f.w. up. and un.s., presence of a 2 nd umpupilled spot towards anal ang., as in $q$.

Obs. - In Mr. Fison's collection is a $\delta$ with 3 spots f.w., and another with 2 spots in yell. patches; also a $q$ with f.w. and band of h.w. pale yell.

E. Tithonus, L. (Amaryllis, Brlil.; Herse, Hb.; Phredra, (isp.) ; $38 \mathrm{~mm}$.

б-with, \& without, dk. brown patch across or.- brn. disc f.w. up.s.

Dist. Char. f.w. double-pupilled apical eye-spot, in connection with absence of wh. (exc. dots), un.s. h.w.

Loc. Gen. r. local in Switz, though ab. in the few places where it occurs. J3asle ('hrist); Myl (Kiseming); Schüpfen and Aarberg

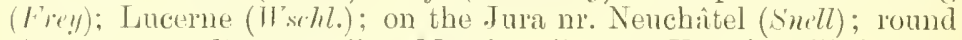
(Heneva, r.c., Jernex, vii.; Meyrin, vii. 26; Telsoix, viii.-ix., \&c. (lil.) ; Les Arants, viii. 5/96 (li.-lim.); Charpigny, vii. 11./01; viii. m. 1900, ab.; Aigle, same dates, v. scarce (II\%.); Tal Leventina (Trup); the Misox valley, e.\%., Roveredo (II/.).

Gen. c. S. of the Alps, and from Cieneva to the Alpes Maritimes, but not beyond $v$. moderate heights.

Directions of Yar. (a.) extra cye-spots up.s. (and un.s.) f.w.

ab. Excessa, 'lutt: “2, З3 or 1 extra spots, usnally small and blind, someines larger and ocellater."

(b.) occasionally in $\delta$, apical eye r. small and unpupilled.

ab. Cæca, Tutt.

(c.) number of wh. points mn.s. h.w.; 0-6; gren. 3 or 4.

(d.) lighter grod. col. up.s., culminating in : 


ab. Mincki, subuld: in wh. the band is yell.

(e.) darkining of up...; ; r. rarely the base of f.w. is dk. brn. and the It. land h.w. obsolescent.

E. Ida, lisp. : $10 \mathrm{~mm}$.

f with, q withont dk. brn. pateh across dise, mp.s. f.w.

Dist. Char. mus. l.w. It. cl. band nerrou and wh. : bru. androconial patch in $\delta$ up.s. f.w. much tivided np loy or. nervures.

Loc. Locamo, viii. (H!!.).

Nice, Vil des Fleurs; Villon Obscur; Cannes, de. (lim.) ; nr. (irisse, on the road to Castellane, vii. 16.91 (Nithrlsme); Iselle; S. slopes of the Tyrolese Alps (Kan ).

Directions of Var. (a.) size: $\delta$ s occasionally r. small (I'ourll). (b.) mn.s. h.w. intensity of col. and markings.

E. Pasiphaë, lisp. (Bathseba, (imlurt); $40 \mathrm{~mm}$.

q with basal half up.s. f.w. or.-brn.; dk. brn. in $\delta$.

Dist. Char. un.s. h.w. broadish wh. band, coming out towards borter between the 2 costal and the 3 anal eye-spots.

Loc. Only in the S. part of the Alpes Maritimes: not a mtn. sp. Directions of Yar. (a.) occasionally the eye-spot nr. apex f.w. up.s. has only one pupil.

(b.) a th spot up.s. h.w., searce (Porell).

[Obs.-In Col. Agassiz's collection are several specimens, from Angers, with the or. replaced by yell., almost of a lemon col.]

ab. Flaya, $11 \%$.; this form may possibly occur also within our range in the Alpes Maritimes.

Tribe Caxosmapum.

Genus, Aphantopus, Willinyirn.

A. Hyperanthus, L. (Polymeda, Sormli); 4.2mm. Fd. plt. I'va, Millimn, ace. : hyb. l.

o v. Ik., of rather lighter, sooty-brn.

Dist. Char. un.s., series of yell.ringed eye-spots, normally 3 f.w., 5 h.w., with $n$ other markings.

Loc. Gen. distributed and c., often ab.; but not usually above 3500ft. : vi.-vii. and sometimes viii.

Directions of Var. (a.) great diminution of size, culninating in : ab. Minor, fiuchs: o $17 \mathrm{~mm}$., of $20 \mathrm{~mm}$; \& un.s. olive-gr., $f$ yellowish olive.

(b.) loss of eye-spots un.s.

ab. Arete, Millire: with wh. centres and yell. rings.

ab. Cæca, Fuchs; with wh. points only. 
ab. Obsoleta, Tutt: with no trace of eye-spots.

(c.) number of eye-spots un.s.; f.w. 0-3, h.w. $4-6$.

(d.) arrangement of eye-spots un.s.

ab. Vidua, Milller: f.w. 2, h.w. 5 (no spots up.s.).

ab. Octoculata, Giize: f.w. 4, h.w. 4 (no spots up.s.).

(e.) shape of eye-spots.

ab. Lanceolata, shim, in wh. they are elongated and somewhat wedge-shaped.

(f.) presence or absence of eye-spots up.s. $\delta$ (always present in $q$ ).

(g.) v. rarely, traces of transrerse lines un.s. h.w. (Tntt).

\section{Genus, Cœnonympha, $11 \%$.}

Prevailing col. dk. bru. and lt. or dk. tawny: hyb. l.

Dist. Char. un.s. h.w., a series of ante-margl. eye-spots, sometimes difficult to distinguish, preceded by, or enclosed in a lt. band, representer in nany sp. only by one or two patches; sp. of small size.

C. Edipus, Fabr. (Geticus, Lsp.; Pylarge, Hb.); $35 \mathrm{~mm}$. Fd. plt. Pore, Carex, Iris psendacorus.

q with broader metallic line un.s. h.w. and more conspicuous eye-spots un.s. f.w. than $\delta$.

Dist. Char. un.s. h.w. lt. band, containing eye-spots, yell., broad, and reaching to marg.; up.s. Nk. brn.

Loc. Said to have been found on a moor at 1)ibendorf, nr. Zürich, between 1520 and 30 , by Liemi (? was it Hero).

S. side of Simplon nr. Homo d'Ossola (Frar.); Cadenabbia on grassy slopes at back of vineyards, vii. / 88 , fairly c. (Lmu.).

Directions of Yar. (a.) tint of grt. col.up.s.

(b.) number and size of eye-spots; v. variable.

C. Hero, L.; $30 \mathrm{~mm}$. Fd. plt. Elymus Liuroum de. $q$ lighter than $\delta$, and eye-spots up.s. more conspicnons.

Dist. Char. un.s. h.w. 1t. band narrow, wh., and rrregular; up.s. dlk. brin.

Loc. Bonfol (Kimliff): nr. Muhlen (Miiller); vi.-vii. v. scarce. Directions of Var. (a.) number of eye-spots.

(i.) often a : ap.s. f.w. in o

(ii.) up.s. h.w. $2 . t$; gen. 3 in $\delta, t$ in $q$.

(iii.) altogether absent, constituting :

(?:) ab. Aretioides, Fologne ; rare. 



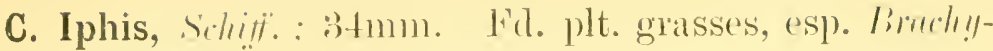
punlimm.

$q$ f.w. up.s. much lighter than of.

Dist. Char. up.s. f.w. slightly (in o much) lighter than dk. brn. h.w.; un.s. h.w. It. band represented by 2 wh. patches.

Loc. Schafthansen (Irall'): the Bechburg (li.-S.) : Aargan (II schl.) : the Jura, nr. Basle ('hrist); Twann and Prêles (Rethenlar $h$ ); St. (ieorges, vi. 8002 (II\%.); St. Cergnes, vi. 26 (lil.); not nncommon in Vaud, ".!. Veytanx, v. 2697 ; vi. 1001; Villeneuve; Caux, vi. e. (0:3, ab. (11\%.); Aigle, vi. 16, 1900 (1B/m.); c. in the Valais; in the Rhone Valley, r.f., under the cliff's between Vernayaz and Martigny; Fully; Saillon; Sion; Sierre; Loèche; Visp; Brig (Far.); and in some places in the mtns., e.\%., Montana, vii. 1199 (ITh.); Zormatt (F(tr.); the Furka, viii. 1/94 (Li.-lirn.); Pont de Nant, vii. 20 (lil.) ; Weissenburg, behind the Old Baths, not c. (H!\%.); the Moléson (Laharne); Mt. Barry, vi. 29, 1900 $(13 \mathrm{~km}$.$) ; Pfäffers (Yll.-Julder); Tarasp, c., and Val Bregaglia$ (liasi,fler).

Le Lantaret, vii. e. 96; La Grave, siii. m. 96 ; above Lanslebonrg, viii. b. 97 ; Larche, viii. b. 1900 ; Abriès, viii. m. 1900 (Thtt); Allos, vii.-viii. (I'ourell); Barcelonette, vii. 92 (Nomis); St. Martin Vésubie nr. top of Mt. Balme de la Fréma (Brm.); mtos. of Carinthia, 5000ft.-6000ft. vii., c. (Lmn.); Kor Alp, vii./97; Lölling, vii. $9 / 97(6 / 1 \%)$.

Directions of Yar. (a.) shade of grd. col. up.s. f.w., esp. in $ठ$.

(b.) size of wh. patches un.s. L.w. sometimes r. small, sometimes almost confluent.

(c.) obsolescence of eye-spots un.s. h.w., learing to :

ab. Anaxagoras, Assmmss: in wh. there are $5 \mathrm{v}$. small ones and no metallic line.

ab. Carpathica, Itormmsali: in wh. they are nearly (or quite) obsolete.

(il.) eye-spots on up.s. h.w.

C. Arcania, L. ; $3: 3 m m$. Id. plt. grasses, esp. Melied ciliatu.

of f.w. up.s. rather lighter than 8 .

Dist. Char. up.s. f.w. or. brn. with dk. border ; un.s. h.w. conspicuous broat wh. band, preceding eye-spots, exc. costal spot.

Loc. The type mainly at low elevations, probably not above 3000ft.; slopes of the Jura, nr. Basle ( $($ 'hrist); the Bechlourg (li..,.); Nenreville ('unleru); Canton St. Gall, Rorshach; Uberutzwyl; Degershein; liernek (Thishlir): Weissenburg, not

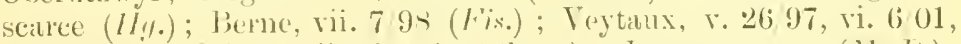
de. (II\%.); Glion, rii. 2901 (lon 01 ); Latusanne, c. $(11 .-1 \%$ ); Veyrier, vi. 17 and 21 ; Hermance, vi. 25 (IBl.); c. in the Valais 
on bushy slopes; neighbourhood of Martigny; Sion ; Lociche; Visp; Brig, Ne. (Fur.); in the (irisons, Malans (Amstein); Misox (ITredn ) ; Val Bregaglia (Bazigher); Pontresina, vii. 84 (Lmu.); Locamo, vi. m. $/ 87$ (. Fomes).

The Dôle (Bulier) ; Bossey, vii. 25, c. (Bl.) ; Grésy-sur-Aix, vii. 2596 ; Bourg d'Aru, viii. m. 96 ('Tutt); Digne, vi. $/ 90$, vii. $/ 91$ (I.mn.); St. Martin Vésubie; Castellane; Thorene, vi.-vii. (Poncell); Susa, vi. 1802 (Lonre); Pré St. Didier, viii. h. 98; Conmayeur, rii. b. 94; Pobbie, viii. b. 01, over (Tutt); Chiarenna, vii. 6, 1900; Cortina, vii., 1900 (li.-lim.); Botzen, vi. e. 01 (Ltme ) Mendel Pass, viii. 195 (Thtt), de.

CObs.--There must be a partia' 2nd brood in the S. as it is noted from the Col di Tenda, x. $7 /(t 2)(R .-B i n$. $)$.

Directions of Var. (a.) narrowing of wh. band un.s. h.w.

var. Insubrica, liitier: gen. rather larger than type, with broad dk. border, and 2 or 3 eye-spots showing on up.s. h.w. ; costal spot un.s. h.w. placed as in type.

Loc. Laquinthal (F'tr.); Brusio, vii. 12, 1801 (Fis.); Crérola (Iirits') ; Bisbinno, vii. 1292 (Mayer).

var. Darwiniana, stifr: smaller than type; wh. band un.s. h.w. of more uniform brealth, more or less enclosing costal spot; v. variable.

Loc. V. c. and gen. distributed over the high Alpes from Chamonix to Cortina (Li.-Jim.) ; in swarms on the Simplon, vii. 1101 , de. ( $(1 \%$ ) ; in some places as low as 2000ft., e.\%., Glion, vi. b. $99, \& c .(T h$.$) .$

ab. Philea, fir.: smaller and approximating wore closely to Satyrion, esp. eye-spots nn.s. h.w.

Loc. Often with Inwiniane at high devations; also with Satyrim, e.\%., Pont de Nant, rii. 4 and 20 (Bll.).

(b.) darkening of grd. col. up.s. f.w., culminating in :

ab. Obscura, Riilll: in wh. it is entirely suffnsed with dk. brn.

Loc. Zermatt; Mayenwand (F'ar.).

ab. Obsoleta, Trutt.

(c.) disappearance of apical spot un.s. f.w.

Loc. Orta, esp. Sacro Monte, ri. b. 1900 (Lure); \&c.

C. Satyrion, Esy). (I'hilea, /h.) ? var. of Arumin, or perhaps of $I_{l}$ his $]$; 30เnm. Fd. plt. grasses.

f up.s., esp. f.w., lighter than 3 .

Dist. Char. un.s. h.w. conspicuons regular wh. band containinef series of small eye-spots.

Loc. V. widely sprear orer the Alps, commonest from $6000 \mathrm{ft}$. to $7000 \mathrm{ft}$, but fonnd higher, and sometimes as low as $2400 \mathrm{ft}$. , $e^{\prime} . \%$, Gimel, vi. $27 / 03$, с. (II/.); vii.-viii. Throughout Switz.; the Tyrol; Piedmont; Saroie; and at Godessart, Basses Alpes. 


Directions of Yar. (a.) $\bar{\sigma}$, darkening of grd. col. up.s. f.w., culminating in :

var. Unicolor, $\| \%$; in wh. all ws. are of a uniform $\pi k$. brn. with greenish tint; $28 \mathrm{~mm}$.

Loc. The Engadine; e.y., Schafberg, vii, 2401 (Fis.); Campfer, c. (Jones $)$.

(b.) absence of border (sometimes v. distinct), up.s. f.w.

(c.) breadth of band un.s. h.w.

(d.) reduction in size of eye-spots, un.s. h.w., culminating in :

ab. Cæca, Wh., in wh. they are absent.

Loc. Les Plans, above Bex (lil.).

*. Dorus, Esy. (Dorion, Mb.) ; 32mm. Fd. plt. Ayrostis, \&e.

q up.s., esp. f.w., lighter than of; $q$ also larger.

Dist. Char. un.s. h.w. series of eye-spots, not including costal spot, in wh. the 2 nd from the top is much nearer out. marg. than those on each side of it.

Loc. The S.E. part of the region; Digne, vi. e. 90 (Jomes); vii. $91(\mathrm{Lmn}$.$) ; Barcelonette, viii. b. 1900$ (T'utt) ; between Barcelonette and Prunières, vi. 25/92, c. (Norris); almost everywhere in dry places in Basses Alpes, Alpes Maritimes, and Var, vi.-vii.; as fine in mtns. as at low elevations ('ouell).

Directions of Yar. (a.) size of eye-spots.

(b.) un.s. rather lighter in the mins. (Pouell).

C. Pamphilus, I. (Menalcas, I'ulu; Nephele, Hufu.); $28 \mathrm{~mm}$. Fd. plt. Cynosurus cristata, P'uet.

o paler and with less marked border than $\delta$.

Dist. Char. up.s. f.w. and h.w. of same shade of brt. yell.-brn., un.s. 1t. band or patches tinged with yell.

Loc. Distributed over the whole region and gen. ab.; foumd up to about $6500 \mathrm{ft} . ; 1,2$, or 8 broods according to altitude; in lowlands from iii. e. to ix., in mtns. vi.-viii. My earliest date is Veytanx, iii. 27,99 .

Directions of Var. (a.) distinctness of apical spot f.w.

ab. Bipupillata, cosmorici: in wh. it is large and (esp. un.s.) distinctly double-pupilled.

ab. Obsoleta, Tutt: in wh. it is absent.

(b.) increase of distinctness of $\mathrm{dk}$. border.

var. (\& ab.) Lyllus, Esp.; in wh. there is a ristinet $d k$. border $\mathrm{f}$. and h.w.

[Obs.-It would seem that this is the characteristic of Esper's Lyllus, and that the form gen. so called really belongs to-] 
"ab. (\& var.) Marginata, Fiilll: larger, with broader border, im.s. lighter with margl. row of metallic bl. spots.

Loc. Only in the hottest parts of the region, as ab.; transitional forms not uncommon in hot seasons.

(c.) loss of markings un.s. h.w., culminating in :

ab. Unicolor, Tutt; in wh. it is entirely reddish-brn.

(d.) a distinct row of eye-spots 1 m.s. h.w.

ab. Ocellata, Tutt: (the type has only traces of this).

(e.) loss in depth of grd. col. up.s. culminating in :

ab. Pallida, Thtt; pale yellowish-tawny, with pale gr. out. marg.

C. Typhon (Tiphon) Lintt. (Davis, Fulur.); $35 \mathrm{mmm}$. Fd. plt. c'arex, Festuca, Rihynenspura, Friophurum.

o up.s. f.w. rather lighter than $\delta$.

Dist. Char. un.s. h.w. lt. band represented by 2 or more patches of dirty wh.: 2nd eye-spot from anal ang. the largest, exc. sometimes the costal spot; further distinguished from $I_{l}$ his by lighter up.s., and from Pamphilus by absence of gr. border up.s.

Loc. Confined to marshy places, and v. local. Schatthausen, only on the "Scharrensumpf " (Ti(t)" ); Zurich on the Katzensee (Fry) ; Utznach, vii. 501; Weesen marsh, vii. \& 01, rather worn (Fis.); Gais and Treissbad (Pey'r-Imherfi); Lake of Hallwyl (II'schl.); Berne (Mrissner); Schïpfen and Val Travers (liothenburli); Glarus (//eet); Teissenburg marshes, not uncommon (// $(1)$; Gimelsur-Rolle, a sloping marshy field on the left of the road to St.

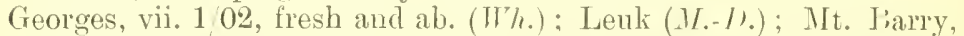
vi. 30, 1900 (Bkm.) ; Brumnen, vi. 6 s6 (Jomes); Ragatz (Amstein); Splugen, below Anteer, vii. 5, 1900 (Li.-Bim.).

Osterwitz, Carinthia, vii. 97 ( $\mathrm{L} m \mathrm{~m}$.).

Directions of Var. (a.) darker gri. col, and more and larger eye-spots, culminating in :

var. Philoxenus, Fsy. (Rotbliebii, II.-s.) ; m.s. also dk. red.-brn., with ante-margl. band of eye-spots; up.s. 0-5 f.w., 1-6 h.w.

(b.) paler grd. col., fewer and smaller eyespots, culminating in :

var. Laidion, likh.; not gen. much lighter than type, but up.s. ocellation reduced to small dots, gen. 1 on f.w. and 1 on h.w.; un.s. basal area h.w. much darker than border, as in type, but with only traces of eye-spots; gen. 1 apical eye-spot f.w.

ab. Isis, Thunbery; the extreme form as to paleness of col.

ab. Obsoleta, Tutt: the extreme form as to absence of ocellation, there being only one dot, h.w.

[Obs.-Infortunately $\mathrm{v}$. little information is forthcoming as to the different 


forms in various localities; the Utznach and Weesen speeimens are, lowever, more or less typical, a tew verging towards I'hilorenus; those from Gimel are much nearer to Lälion: the Brunnen specimen is reported as Latidion, and that from the splugen as $[$ sis.]

Sub-Fam. EREBIINA.

Tribe (ENEÏDI.

Genus, Eneis, Ml. (Chionolas, Bselr.).

E. Aëllo, H\%. (Norna, Hl.; Glacialis, Shlurml) ; $52 \mathrm{~mm}$. Fd. plt. grasses : hyb. 1.

of dk., rather washed-out brn., with tawny ante-margl. land; o rather washed-out tawny.

Dist. Char. Conspicuous wh. veining and small transverse streaks on dk. h.w. $1111 . \mathrm{s}$.

Loc. Gen. at high elevations, from $5500 \mathrm{ft}$. to $8000 \mathrm{ft}$, but occasionally in plains, e.\%., at ft. of Mt. D'Autan (Far.), \&c.; in N. Switz. only reported from the Schäfler in Appenzell (Tïschler), and Pilatus (Knecht); gen. distributed in the Bernese Oberland and the mitns. of Vaud, the Valais, and the Grisons ; e..., the Prienzer Rothhorn and Münnlichen (Fis.); Engstlen and Tannen Alps (Bakir); S. side of Rochers de Naye (Fis.); (ilacier de Trient; Bovine; Arpilles; Grand St. Bernard: Gemmi; Grimsel ; Laquinthal, de. (Far.); Arolla, vii. 11, 1900 ; 'T'urtmannthal, vi.

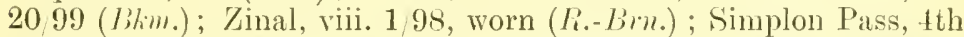
Refuge, vii. 1n. 98, c. (W7.); Steinenthal, vii. b. 02 (Sheldom); Maloya, vi.; Pontresina, vii. /95, worn (Miss litn.); Campfer, rather c., just below tree-limit (.Iomes), dce.

Eastwards to the extremity of the region; e./., Brenner, Postalp, vii. 2s, 1900, worn (K.-Bm.); Campiglio and Pejo, vii. 95; Heiligenblut, vii. 2597 ( $\mathrm{L} . \mathrm{mm}$. $)$; also to the S.W. ; Le Reeulet in the Jura, vii. 24 (Jil.) ; St. Rémy (Balie?) ; St. Martin Vésubie, vi. e., vii. b. (I'virell); Pepiori; Palme de la Fréma; Madone des Fenêtres (Brm.).

[Obs.-The little fiction that this sp. occurs only every two years, alternately in the Bernese Oberland and the Valais (such a convenient arrangement for collectors !) is disproved by the above dates ; it is, however, very likely that in cold seasons and at great elevations the l. hybernates twice.]

Directions of Yar. (a.) depth of grd. col. and consequent distinctness of band, up.s. $\delta$.

(b.) number of spots: (gen. 2 f.w. and 1 h.w., but sometimes only 1 f.w., and often 2 h.w. ; frequently on up.s. h.w. traces of 2 more).

Genus, Erebia, 1) „llı.

Prevailing col. dk. (gen. v. dk.) brn., usually with red-brn. or or.-brn. bands or spots, gen. containing pupilled or unpupilled eye-spots. 
$q$ gen. with lighter markings and often with more eye-spots than 0 .

Obs.-The $q$ in most cases comes out, or, at any rate, shows itself, considembly later than the $\delta$; the former is gen. to be found among flowers or grass, the latter has a predilection for routs and rocks.]

The following remarks include the genus Melampias, Fib., for the erection of wh. no adequate excuse appear's to me to exist (v. introduction).

This genus is in many cases $\mathrm{r}$. local, and in all has more or less definite limits of altitude; these I have endeavoured to tabulate, the figures, in English ft., being mostly founded on those given by Fren (who uses Parisian, not English, ft.), but alterer in many cases in accordance with subsequent experience. It must be understood that "plain" does not mean sea-level, but the general valley level of the districts in wh. the sp. occur, and of course the figures are only approximate. Epistygne, plain to t000ft.; Medusa, plain to $4500 \mathrm{ft}$; Ethiops and Stygne, plain to 5500ft.; Ligea, plain to $4500 \mathrm{ft}$, and with var. Adyte to $6000 \mathrm{ft}$. or more: Evias, plain to 7000ft.; Neoridas, 2000ft. to 6000ft.; Ceto, 2700ft. to 5500ft: Nerine, $3300 \mathrm{ft}$. to $5000 \mathrm{ft}$. : (Eme, 3000ft. to 6000ft. (but at Glion at $2000 \mathrm{ft}$.$) ; Euryale, 3000 \mathrm{ft}$. to $6500 \mathrm{ft}$. : Scipio, $3000 \mathrm{ft}$. to $7500 \mathrm{ft}$; Manto, $1000 \mathrm{ft}$. to $6500 \mathrm{ft}$. ; Goante, $1000 \mathrm{ft}$. to $7000 \mathrm{ft}$; Melampus, $4500 \mathrm{ft}$. to $6500 \mathrm{ft}$. (exceptiomally 3500ft. to s000ft.); Pharte, Eriphyle, and Tyndarus, 4500ft. to 6500ft.; Christi, 1500ft. to $7000 \mathrm{ft}$; Nuestra, 5000ft. to $8000 \mathrm{ft}$.; Arete, 5500ft. to $6000 \mathrm{ft}$. (Lmu.) ; Pronoe, 5500ft. to 6500tt.; Epiphron vars., 6000ft. to $8000 \mathrm{ft}$. (exceptionally 4500ft. to 9000ft.); Lappona and Gorge, 5.500ft. to 9000ft.; Flavofasciata, 7000ft. to 8000ft.; Alecto, $7000 \mathrm{ft}$. to about $10000 \mathrm{ft}$.

\section{*E. Epiphron, Kinoll (Egea, Brlit.; Tanthe, Hh.) : $28 \mathrm{~mm} .-34 \mathrm{~mm}$. Fd. plt. Aira mrese, and A. cospritosa. $q$ with more distinct markings than $\delta$.}

Dist. Char. a slight ang. in h.w. about half-way down out. marg.

Loc. Not on the Jura, but in one form or other distributed over the high Alps of the whole region. Unfortunately, in many, indeed in most cases, the special forms from different localities are not mentioned in books, letters, or lists. and in many collections the locs. of the specimens are not attached; hence a great difficnlty arises in giving, what is most desirable, the exact habitat of the different rars. Speaking ronghly, it may be saict that the type is only reported from above Certosa di Pesio, vi.-vii. (Noris); that var. Talesiana is to be found on the $S$. slopes of the Valaisian alps, the Mayenwand, the Pierre-i-roir, and the Simplon; that var. Cassinge is the more usual form on the S. French. Piedmontese and Valaisian alps, and round Engelberg; vars. Nelemus and Muemon in the Bernese Oberland, the Grisons and the Tyrol; though Nelanns is to be found as an ab. throughont the region; ab. (Absuleta appears to come chiefly from the Grisons: vii. and viii. are the usual months of appearance, according to altitnde, but also vi. in the $\mathrm{S}$. 


The type has the band continuous, with large eye-spots, pupiller in $q$.

Directions of Yar. (a.) decrease in size and distinctness of markings.

var. Yalesiana, $11 .-D_{.}$: $31 \mathrm{~mm}$; a large form with continuous band and large spots.

var. Cassiope, l'abr.: band continuous on f.w.; but on h.w. only 3 or 4 lik. dots in fulvous ringrs.

var. (\& ab.) Nelamus, liste. (Bernensis, 1/.- I.); band reducert on f.w. and obsolescent on h.w., blk. dot: almost (or quite) absent.

var. Mnemon, Hakcorth: band broken up into vings; gen. 4 f.w., 2 h.w.

ab. Obsoleta, Tutt: bands and spots alike obsolete.

Obs.-Nany intermediate forms occur.]

(b.) great rariation in number and size of spots.

E. Melampus, Fssl.; $32 \mathrm{mmm}$. Fd. plt. I'ou rumur, ec. $q$ with longer and narrower ws. than $\delta$, markings gen. more pronounced and yellower.

Dist. Char. blk. unpupilled spots in red-bm. macular band f.w., and rings h.w., up.s. and un.s., in connection with small size (c. Friphyll').

Loc. One of the most widely distributed and ab. of the min. lirebias: in the fir zone, and in high pastures and mearlows thronghont the region; vii.-viii. according to elevation and latitude. Occasionally found considerably lower than its normal range, r.\%.,

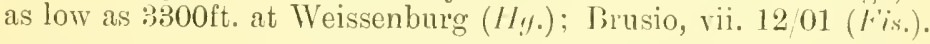

Directions of Yar. (a.) tendency to stronger marling, culnuinating in :

ab. Sudetica, Stin.: wh. has also somewhat lighter and yollower spots.

Loc. Priitigau (Yll.-Dolder).

(b.) diminution in size of reddish patches and blk. spots.

(c.) number of blk. spots (the normal number is: up.s. f.w. 4, h.w. 2, the lowest spot on f.w. and the top one on h.w. being without blk. ; un.s. f.w. 2, h.w. 3 or 4).

Obs.-An example taken at lianda by Frey with a wh. spot on each w, up.s. is recorded as :

ab. Randæ, l'ar.

E. Flayofasciata, He!nue: :30mm. Fd. plt. (and 1.) unknomin. 
o with larger spot than $\delta$.

Dist. Char. un.s. h.w. broad ante-margl. band yell. with blk. spots.

Oobs.-This sp., the smallest Frebia, closely resembles some forms of Epiphron on up.s., but without ang. in h.w.]

Loc. Tal Maggia, "grassy slopes above Fusio, in close association with the outcrop of a wh. rock of dolomitic composition," vii. 1-12 $99(1 / \%)$; Alpe Pianascio, vii. 12-1399 (Miiller); Bernhardin Pass, vi. 96, 1 б (Mat!y) ; 2 places nr. Pontresina, viz., Schafberg, above 1st restamrant, vii. 2401: and Tscherva Glacier, behind restaurant, 1 ๙े, vii. 1001 (Fis.).

Directions of Yar. (a.) un.s. h.w., brearth, regularity and depth of col. of yell. band.

[Obs.-The Tscherva Glacier specimen has a slightly broken band, with v. irregular inn. edge.]

(b.) number of spots f.w. up. and nn.s. (normally 5$)$. un.s.]

[Obs.-I have a specimen from the Alpe Pianascio with 4 on up.s. and 6 on

*. Arete, fithr.; 320mm. Fd. plt.? tiru cespitusu (not successfully reared).

of with dk., of with yell.-gr. h.w. un.s.

Dist. Char. ante-margl. row of tiny wh. spots un.s. h.w., just visible on up.s.

Loc. Styrian and Carinthian Alps, e.!., Stelzing, vii. $1197, \mathrm{v}$. local, on Sau Alp, but not on Kor Alp (Lmm.) ; Salzlurg, vii.-viii. (simler).

Directions of Yar. (a.) increase in size of wh. spots, esp. in $q$, culminating in :

ab. \& Albofasciata, Hiifurr: in wh. they are confluent.

E. Eriphyle, Fr. (Tristis. H.-s.) : $3: 3 \mathrm{~mm}$. Fd. plt. grasses $(1+a r$.$) .$

o with eye-spots, esp. np.s. f.w. more marker than in $\delta$.

Dist. Char. redlish-brn. (in \& yell.-bun.) markings up. and un.s., f. and h.w.; but the 2nel spot firom costet h.r., esp. mn.s., noticeably nearest the hase. Differs also from Melampus in absence of blk. dots in the spots of h.w., and from Pharte in having gen. blk. dots in the 2nd and 3rd red brn. patches in o f.w., and in more in $q$.

Loc. $T$. local, and gen. scarce, occuring in Central and E. Switz., in the Styrian and Carinthian Alps, and again in S. Piedmont; vi. e. to viii. The Niesen (Jirgmi); Kandersteg and the Gemmi, small and dk. (linthenbarh); ft. of the Furka, to right of Rhone Glacier; Mayenwand; Cirimsel; Alpes de Lens (fiar.); Trübseealp, rii. m. 01 (Lurr); Devil's Bridge (Frry); from the 

Bernhardin Pass to the Hinterrheinthal (Rrthenharh): Dischmathal, vi. $2 \overline{7}$, and rii. 201 (l'is.); Sertigthal and Fluelathal, viii. 82

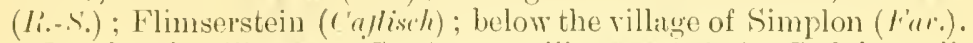

Innsbruck, viii. 197 ; St. Anton, viii. $197(1 / \mu)$; Stelzing, vii. 1197 ; Sau Alp and Kor Alp, vii. m. 97 (L.mu.); Certosia di Pesio, r. ab. at heit of Val Arpi, in Val Marguaress, and under the summit of Monte Costa Rossa, vii. 11, de., 92 (Nomis).

Directions of Var. (a.) increase in amount of red-bru. up.s.

ab. Intermedia, frey: in wh. the spots are larger.

(b.) loss of blk. dots f.w.

ab. Impunctata, Häner: wh. has also r. large red-brn. spots up.s. (c.) lighter border and reddish suffusion un.s. f.w.

E. Pharte, Hl).; $37 m m$. Fd. plt. grasses (Fur.). o with dk., of with yellowish un.s.

Dist. Char. whon! or redye-shapen red-brn. (in of yell.-brn.) spots up.s. f.r.; none of the spots, up. or mn.s., f. or h.w., containing blk. points.

Loc. Wide-spread, but somewhat local, and not gen. c.; vii.-viii. Obergmrnigel (Meissuer) ; Kandersteg, vii. 991 (Rosa); both sides of the Gemmi, on the N. at the entrance to the Gasterthal, and on the slopes of the lienthal ; the Grimsel, above the Handeck falls, d.c. (H.-IJ.); Gadmenthal (Liitzr'); Little Scheideck (Fi...); the Surenen (C'lurist) ; Trübseealp, vii. m. 01 (Lorr) ; Pilatus (I'cul); Mühlebachalp, above Engi; Kalfenseralp (Fisenrint); about a mile down the Gisteig side of the Col de Pillon, riii. b. SA (.Jones); the Diablerets (F'is.); la Vare, above Pont de Nant, vii. 11 (lil.); Dent du Midi, viii. 602 (Fis.) ; Glacier de Trient; Eorelia; Arolla; Alpes de Lens; above Obergestehn; between liérisal and the Simplon Pass; Rossborlenalp, ide. (F'ar.); Flimserstein (l'aflisch);

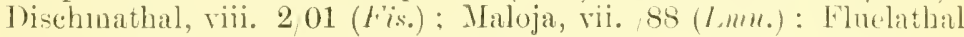
(li....) ; Tal Tuoi, vii. m. $1900(\mathrm{c} / \mathrm{h}$.).

Le Lantaret, vii. 30, viii. 5,96 (Thit); Cortina, wools abont Tre Croce, vii. 2:3, 1900, not c. (li.-lirn.); Stelvio, Eppelshein; Innbruck, viii. 1/97; Kor Alp; St. Anton, vii. m. 97 (l.mu.).

Directions of Var. (a.) diminution in size and number of spots, esp. f.w., culminating in :

ab. Phartina, Sttr.: in wh. they sometimes scarcely appear.

Loc. Lent du Midi, viii. 602 (F'is.); 'Triibseealp, vii. m. (01, not uncommon; Genmi (Iare); Tal T'noi, vii. m. 1900) Fincio, vii. h. $99\left(1 / h \mu^{\prime}\right)$, \&ce.

(b.) increase in conspicuousness of red-brn., enlminating in :

var. (\& ab.) Fasciata, Spmler: in which they become a bancl (always, however, divided by the dk. nervires), reth-hn. in of. yell. br). in $q$. 
Loc. Styrian and Carinthian Alps (Spuler); some specimens from the Trübseealp approach this form closely.

Guarda, vii. 22-31, 1900 ; Fusio, vii. b. 99.

\section{E. Christi, liäzer ; $32 \mathrm{~mm} .-38 \mathrm{~mm}$. Fd. plt. (and l.) unknown. \\ $f$ up.s. f.w. band lighter and less broken than in $\delta$.}

Dist. Char. up.s. f.w. band containing eye-spots (unpupilled) follows curve of w.; un.s. h.w. cl. band inconspicuous, but with out. edge always distinguishable; differs, further, from Epipheron and vars. by absence of ang. in h.w. ; from Mnestra by band of f.w. being much nearer to ont. marg.; by band un.s. f.w. being always distinguishable from cl. suffusion (wh. in 'hristi does not exist on up.s.), and gen. by the ante-marg. blk. spots un.s. h.w.; from Melampus and Erriphyle, by absence of all rust col. or yell. un.s. h.w.

Loc. Laquinthal, and thence occasionally to Simplon Hospice (Fat.) ; 1st half of July (Far., Fis., Wth., lic.).

Directions of Yar. (a.) relative length and breadth of f.w., always more or less long and narrow.

(b.) col. of band, wh. varies from rich red. brn. to rich yell.-brn.

(c.) number of spots f.w., 2.4.

[Obs.-So far as I know no specimen has yet been taken without eye-spots f.w., but I should expect this ab. to occur, as they are sometimes v. inconspicuous.]

(d.) conspicuousness of spots h.w., esp. up.s.

(e.) visibility of cl. band un.s. h.w. (i.surrì).

[Obs,-In spite of criticisms to the contrary, there is really no doubt of this being a good species. It resembles to some extent 4 others ( $v$. supri $i)$, but, though itself a variable sp., it bas always churacteristies wh. do not disappear, and wh. render it clistinguishable from any other. I have never found any great difficulty in identifying specimens, and in every case my judgment has been independently corroborated by Chne. Favre, who has had much experience of the sp. There is nothing impossible, nor, indeed, contrary to what might naturally be expected in this local genus, in the limitation, so far as is at present known, of its range; it is not so very moh more restricted than Flarofascinta, Zapateri, or even Arete, Scipio, Neoridas, de., and may very likely yet be found in other neighbouring, or perhaps more distant, localities.]

E. Mnestra, Hh.; ;35mm. Fd. plt. grasses (Fur.).

$q$ with just visible ante-margl. band un.s. h.w., wh. in $\delta$ is unicolorons.

Dist. Char. up.s. f.w. broad red-brn. band, almost equidistant throughout from out. marg.; gen. suffused on inn. edge, sometimes almost to base of w., and continned more or less on h.w. ('The squarest of the smaller Eirebias.)

Loc. La Vare, above Pont de Nant, vii. 11 ( $B l$.$) ; mitns. round$ Martigny, Arpilles, Bovine, Trient, Alpe-de-Fully, Pierre-ì-voir; 

also above Mayens de Sion; Erolena; Val d'Anniviers; Loècheles-bains, \&c. (Far.); Ferpècle, viii. 11. 99; Col du Torrent, viii. b. 99 ('Tutt) : Arolla, vii. 11-16, 1900; Riffelalp, vii. 1099 (likm.); Saasthal, vii. 94 (Mis.s F'tu.); Findelen, v. small (Fis.); Steinenalp, vii. 399 ; Simplon Village, vii. 1001 ; viii. 399 (Wh.); Laquinthal, vii. 3099 ( $(\%$ \%) ; Belalp (Benteli); the Grimsel, nr. the Aar Glacier (Meismer); Meienthal (I'sehl.); Furka, vii. $/ 89$

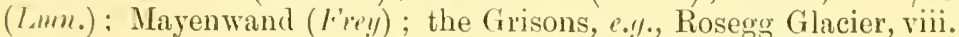
301 (F'is.); Pontresina, rii. 95 (Miss Ftn.); Naloja, vii. $/ 88$ (Lmu.) ; Daros, viii. 2, 1900 ; Guarda, vii. 22-31, 1900; above Fusio, vii. b. $99\left(c^{\prime} / h^{\prime}\right)$, ice.

Alps round Chamonix, c. (Meissner); the Brévent, viii. 1802; Le Lautaret, viii. b. 96 ('Tutt); Allos; Colmars; Beauvézer; St. Martin Vésubie (l'orell); top of Stelvio Pass, vii. 12, 1900 (li.-lim.); Petit St. Bernard, viii. b. 98; The Grammont, viii. b. 94 (T'utt); Pejo, vii. 95 (Lmm.).

Directions of Var. (a.) presence or absence of 2 apical eye-spots, up.s. f.w.

(b.) presence or absence of wh. pupils to these eyes when existing.

(e.) extent of red-brn. suffusion up.s. f.w.

\section{E. Alecto, Hl.; 48mm. Fd. plt. grasses (F'rr.).}

o h.w. up.s. and un.s. slightly less unicolorous than in $\sigma$; in type $2 \mathrm{v}$. small apical eye-spots up.s. f.w.

Dist. Char. large size, in connection with $\mathrm{dk}$, nearly unicolorous, h.w.

Loc. Distributed over all the highest Alps of the region, in one form or other, the type (as given above) being the usual form E. of Switz., the form without eye-spots, Glacialis, being more usual in Switz. and to the W., though in many places both occur together; vii.-viii. : Mr. Rowland-Brown remarks that on the Swiss side of the Stelvio he found only Glacialis, on the Austrian side only Alecto, viii. 197. Laharpe, as quoted by Frey, was mistaken in supposing the sp. to be absent from the Vandois Alps; e.\%., Dent de Moreles, vii. 10; Grand MLereran, vii. 21; Alerto, Gilarialis and I'luto (Iil.). Mr. Norris observes that, at Godessart, Alerto and l'lito were attracted by his blk. net, and that he thus took a good series. Mr. Buckmaster took Glacialis on the moraine of the Allalin Glacier as early as vi. 2194. In Switz. it does not usually occur in large numbers, but in some localities further $\mathrm{E}$. in the Alps, e.!.., the E. side of the Stelvio it is ab. Mr. Rowland-Brown speaks of the E. Stelvio specimens as much larger than the Swiss, but Mrr. Fison bas taken v. large ones with fine blk. grd. col. on the Piz Languard, viii. 501.

Directions of Yar. (a.) absolute disappearance of mahogany suffusion.

ab. I Persephone, kisp.; the apical eye-spots remaining.

[? Is this the supposed $F$. Melas from Campiglio taken by Mrs. Nicholl in 90 , and afterwards vii. 25,92 by Mr. Elwes, and in vii. 
95: by Mr. Lemann and Dr. Chapman, the latter of whom afterwards wrote (lintomolorist, xxxiv. 17) that these specimens had been proved by Calberla to be Glacialis.

(b.) disappearance of apical eyes in $q$, with increase of mahogany stufusion in both sexes.

var. Glacialis, Esp. (Alecto, $F \%$ ); wh. has the suftusion broad but inconspicuous.

Loc. The more usual form in Switz., and the W. and S.-W. alps; occuring also in the E. Alps; r.!., Heiligenblut, vii. 25/97 (Limll.).

(c.) tendency of all markings to disappear, culninating in :

ab. o Pluto, Exp. (Alecto, Listr.: Duponcheli, (1hth.); almost blk. up. and un.s.

Loc. More c. in the $\mathrm{W}$. than in the E. of the rewion; 1irienzer Rothhorn, vii. 1692; Anthémoz on the Dent du Midi, vii. 2902 (lis.) ; Gomergrat, viii. $1001(S / m p e)$; \&c.

On the Domrbes, Digne, vii. 11-16/89 (Mrs. Nichull); nr. Certosa di Pesio, on Monte Faschia, 7000ft. to 8000ft., and at Gias del Ortiga (Norris); \&c.

E. Manto, Fisr. (Pyrrha, Fulr.); 40mm. Fd. plt. grasses $(1 \%$ \% $)$.

o with mahogany oi chull fulrous, $q$ with ochreous-yell. spots uli.s. h.w.

Dist. Char. $q$, col. of spots un.s. h.w., o 2 small unpupilled apical eye-spots up.s. f.w. in comnection with more or less oblong blotches un.s. h.w., the largest being nu. costa; differs from Pharte by having blk. spots on the rea-brn. patches up.s. f.w., and from (ito var. Hosemra by absence of wh. pupils in these spots.

Loc. Cien. distributed orer the Bernese, Vaudois and Talaisian Alps, though gen. in small numbers in the latter canton; $e . \%$, Weissenburg, v. ab. (Hy.): Müren, vii. 24-viii. 12, 1900 (I\%.); Diablerets, c. and r. fine, viii. 85 (Jones); Tour d'Ai, viii. 797 (Tmal'y); Caux, vii. 01 (Lmn.); Val d'Anniviers, Ponchette to Chandolin; Loc'cle-les-bains; Riffelalp; Simplon, \&c. (v'ar.); Engelberg, on wooded slopes (thrist); Pilatus (l'anl); Alps of Appenzell (Taischler), and St. Gall (Kiscming); Oberalp, viii. 2695 ( $(\% /$.$) ; scarce in the Grisons; Engadine, in the valley, and A I_{P}$ Tschitta above Bergiin ( $/$ ll.).

Bremer on the top of the pass, ant on Postalp, vii. 27, 1900, v. c. (li.-lim.); [nnsbruck, viii. $1 / 97$ (Imm.) ; Sit. Anton, viii. 497 $((h \%)$; reported from the Basses Alpes by Millire' and l'onsel.

Directions of Yar. (a.) tenelency to diminish in size, culminating in : 


var. Pyrrhula, Frey: $32 \mathrm{~mm}$. : with spots and eyes obsolescent.

Loc. Only in the highest haunts of the sp., $\%: \%$, on the Albula Pass, high above the tree limit, vii.-viii. often c. (Fry); Gurgaletsch, above Parpan (c'ullisch). [A transitional form not quite so small and with better minked spots and eyes is found at somewhat lower elevations, e..., Daros (Fry); Mainnlichen, WT. of top, rii. 21, 1900 ; Dent du Midi, viii. 602 ; Mythen, viii. 25 02 , rather worn (liis.).]

\section{(b.) spots of $\mathrm{un.s.}$ becoming lighter in 3 .}

ab. Bubastis, Meismu (Pyrrha Maccabiens, Fr. ; in wh. they are whitish; \& with ehequered fringe.

Loc. The Schinbero in Aargan (li.si.); Garlmen (\%ll.-lholder); Pilatus (I'schl.); Engelberg ('hrist); Loèche-les-Bains (Meissnet); Glacier de Trient (I'schl.).

(c.) tendency of spots, esp. mn.s. h.w., to diminish in size and number, culminating in :

ab. Cæcilia, 1/h.; in wh. they have almost disappearen on up.s., and only show traces of the largest on min.s. h.w. (enough, however, to distinguish from (lime ab. Lutpens).

Loc. Mürsen, vii. 21, \&c., 1900 (I\%.) ; Sefinenthal; Männlichen; Dent du Midi (I is.) ; Engelberg ( $/$ hist); on the Joch Pass (Zll.-Lolder) ; Gadmen (Rivitzer) ; Guarda, vii. 1900 (Chp.).

Brennel Pass, vii. 27, 1900 (I..-Bm.).

\section{E. Ceto, Hl.; 40mm. Fd. plt. I'en annul, ife.}

o macular band lighter and more conspicuous than in o .

Dist. Char. ante-malgl. band of brt. bru. spots, almond-shaped, with blk. centres, f. and h.w., mp. and un.s. ( 1 . Melusu).

Loc. Local, and in Switz. chietly in the Talais and the (irisons; possibly, however, it may be overlooker, as its flight is confined to the 1 st fortnight or: 3 weeks of July. Outsicle the 2 Cantons named, I find: Dent de Corjeon, Fribourg (Kame); les Ormonts, Fand $(M .-7)$; Fusio, Tessin, vii. b. $99\left({ }^{\prime} / h^{\prime}\right)$; Kandersteg, Berne, rii. 197 (l'ostans); in many locs. in the Valais, and when found gen. ab.; Mt. Raroire; Arpilles; from Martigny Combe to the Forclaz; liovine; Fully; Sembrancher; Grand St. Bernard; nr. Lerron on the Alpe du Lens; Frolena; Inden; Loèche-les-bains, Rc. (I'ur.); Turtuannthal, vi. 20, St. Nicholas and Zermatt, vi. 29 99 (likm.); the Riffel, rii. 01 (l.mm.); Ganterthal, vii. b. 01, v. ab. (IIh.); Zinal, viii. b. 9S, Y. Worn (li.-lim.), Ne.; in the Gisons, the Schafberg, vii. sis (1.mn.): Promontogno, vi. 95 (1/iss /.tn.); above Vicosoprano, and at Sanaden (Men!flbir); Ardetz and Tarasp) (Fillices); Fusio, vii. 1-12,99 (1/h\%.).

The lirévent, viii. $180^{\circ}$; Le Lantaret, vii. e. 96 (Tutt); Seyne; Allos (l'urell); Ozglosse, Malmorte, \&c. (Kane); St. Martin Vésubie (I'unfll): Certosa di Pesio, r. c. (Norris); Susa, vi. 2499 , v. fine (li.-lim.); Commayeur, vii. b. 02 (Lme); Chiesa, vii. 9, 1900, worn (li.-Lrn.); Macugnaga, vii. 96 (Mi.s Ltn.) ; Trafoi, vii. 14, 1900, 
v. ab. (Li.-lirn.) ; Mendel, vii. 95 (Lum.); Campiglio, vii.m./95; Pejo, rii. e. $95((\%)$.

Directions of Var. (a.) decrease in number and size of spots, culminating in:

var. Obscura, lirits'; in wh. they are v. small, eren in $q$.

Loc. Glacier de Trient; Tal de Bagnes; Laquinthal (Far.); just below Simplon Village, vii. 10,01, v. ab. ( $1 / \%$.).

Le Lautaret, viii. 1/96 (Tutt); Macugnaga (F'ar.).

ab. Caradjæ, Cuflisch: in wh. the spots have almost (or quite) disappeared, and wh. is also smaller.

Loc. In the highest parts of the range of the sp.

(b.) tendency to lighter col. of spots, culminating in :

ab. Phorcys, Frr.; in wh. they are whitish with brn. centres.

Loc. St. Martin Vésubie; Balme de la Fréma; Madone; Berthemont, scarce (lim.).

E. Medusa, Fuln. (Ligea, Esp.; Medea, lihll.); $42 \mathrm{~mm}$. Fd. plt. Panicum sanguinale, \&c. (Far.).

Brt. rich brn.; \& rather larger, and grd. col. un.s. considerably lighter than 0 .

Dist. Char. band of deep yell.-brn. spots, most of wh. bear wh.pupilled eyes, f. and b.w., up. and un.s. Differs from Jithiops in alosence of bands un.s. h.w.; from ('etn in the spots, esp. un.s. h.w., being wh.-pupilled in more or less circular rings instead of being umpupilled in almoni-shaped dashes.

Loc. Gen. distributed throughont Switz. in the lowlands and hills, v.-vi., in the mins., vi.-vii., but rarely in any considerable numbers exc. at moderate altitudes, and much commoner in $\mathrm{N}$. than in S. Switz.; ab. however, at Canx, v. e. and ri. 97 (II\%.); distinctly scarce in the Valais, thongh foumd throughout the canton.

Susa, vi. 2499 (Ii.-lim.) ; Lölling, rii. 997, wom (1\%\%.); Stelzing, vii. 11/97, worn (Lmn.); (reported from high mtns. of the Basses Alpes and Alpes Maritimes, but doubtful).

Directions of Yar. (a.) decrease in number and size of eye-spots, culminating in :

yar. Hippomedusa, thes. (Subalpina, Gummpenbert); wh. is also smaller, and in o bas the lrn. blotches v. snall.

Loc. Basle and Liestal (Christ); the crests and high urass slopes of the Jura, e.!., Weissenstein, v. c. (11.-1).); the Bechburg, v. c. (L..-i.); (lower down, e..., at St. Georges, specinens do not greatly differ from the type ( $\mathrm{W} /$.) ; between Lanterbrumen and Wengen; Nairs and the Gurgaletsch (cattisch); Tarasp (hane); Fusio, vii. $1-1299(1 \% \%)$.

The Stehio, but nct reaching to Franzenhöhe (Fry); Stelzing (Lum.). 

ab. I Procopiani, Hormusalii: an extreme form in wh. the eyespots are unpupilled.

(b.) increase in size and number of eye-spots, culminating in :

yar. Psodea, Ill. (kumenius, $F r$.) ; wh. has the band lighter, and nearly (often quite) continuons.

Loc. Usually an E. form; reported from E. Switz. and also (Inost curiously) from Pontarlier (hane).

Macngnaga, not scarce (liritier); Styria (Kame).

Obs.-The usual range in number of eye-spots is : $\sigma^{*}$, up.s. f.w. 3-5, h.w. 3.4; un.s. f.w. 3-5, h.w. 3-6; \&, up.s. f.w. 4-6, h.w. 4-5; un.s. f.w. 4-5, h.w. 1.6.]

\section{E. Eme, $1 / 6 . ; 39 \mathrm{~mm}$. Fd. plt. grasses (Fur.).}

$\delta$ v. dk. brn., \& lighter and eye-spots more distinct.

Dist. Char. up.s. f.w, 2 r. small, wh.-pupilled, blk. apical eyespots, in small, dk., red-bru. patebes; 3 on up.s. h.w. in rings of same col. (in $q$ gen. 4, and often an extra one on f.w.); differs from Pitho in absence of bands un.s. h.w.; from Medlusa in red-brn. patches being $d k$. and inconspicuous; from ceto, rar. Abscura, in the patches being red-brn., and not almondshaped; from Manto in the eye-spots un.s. being pupilled, and being placed in much smaller and rather darker patches; from Stygme var. I'alesiaca, in the absence of the long mahogany patch un.s. f.w.

Loc. Local ; abore Einsiedeln ; in the upper Sihlthal (Knecht); Bryschalp in the Wegrithal (F,y); Tribseealp and Surenen (Christ) ; Gadmenthal (lint:er) : Weissenburg, large and lt. (H\%.); Mt. Barry, vi. 29, 1900 ; Rossinières, vii. 5, 1900 (KHm.) : Miihlebachalp, above Engi $(F, y)$; gen. distributed in the Tiernese Alps; f\%., Gurnigel, v. ab. (11.-I).); Mürren, vii.e., viii. b. 1900, c. $(11 \%$.); haudersteg, and the Gemmi, not uncommon, vii. 99 (lirsa); not uncommon in the Vaudois Alps; e..., Pont de Nant, vii. 11 (l;l.) ; Cans, vi. m. 97; Glion, vi. b. 99 (H\%.); not c. in the Valais, Anzeindaz, Col de Cheville; Laquinthal (F'te. ) Dent du Midi, r. small, viii. 602 (Fis.).

Le Reculet, vi. 21 and 26 (lil.); Cortina, vii. 1900, not e. (.Junes).

Directions of Yar. (a.) tendency to disappearance of eye-spots, culminating in :

var. Lugens, Stgr.; in wh. they have totally disappeared.

Loc. Mürren, rii. e., viii. b., 1900 (II\%.); Trümletenthal, vii. 1001 (Fis.) ; Einsiedeln (Fry); Glacier de Tricnt (Far.).

(b.) tendency to increase in size of rcil-brn. blotches containing eye-spots, culminating in :

var. Spodia, styr. (Psoden, lir.) ; wh. is also of greater size; 
eye-spots still small, but in more conspicuous blotches than Medusa var. Hiplpomedusa.

Loc. Gemmi and Laquinthal ( $F$ (ar.).

Gen. the form of the E. Alps, Austria, Styria and Carinthia; e.!., Pejo, and Mendel Pass, vii. 95 (Lmm.).

E. Stygne, (llks. (Pirene, Hl.); 42mm. Fd. plt. grasses $(\mathrm{l}(\mathrm{lr}$.$) .$

o lighter, with eye-spots more conspicuous than $\delta$.

Dist. Char. un.s. f.w. more or less wedge-shaped mahogany (in $q$ wore fulrous) patch with 2 wh.-pupilled eyes.

Loc. The whole length of the Jura, with conspicnons bands and eye-spots $(F r y)$; $\because \%$. Tallorbe, vii. $203(H \%$.$) ; Pilatus and the ft.$ of the Mythen (I'aul); Engelberg (christ); Pont de Nant, vii. (I)l.); the lower alps of cantons Berme, Unterwalden, Glarus, Appenzell, St. Gall, and the Talais (frey); sometimes in the plain, e.f., under the cliffs at Martigny towards Vernayaz, vi, 27,02 (Sheldom); same date 1900, worn, vi. m. 03, fresh ( $11 \%$.); Brmmen, vi. b. 97, a few (.Jmes); later at higher elevations, e.!., Arolla, rii. 11, 1900 (lim.); Saas, viii. b. 97 (li.-lim.); in the Grisons at Churwalden (II!.) ; Bergin (\%ll.); Sphugen road above Thusis, vii. 5, 1900 (R.- $\operatorname{lin} n$.).

La Flégère, viii. b. 97, a few (.Jomes); The Brévent, viii. 18/02; Petit St. Bernard, viii. b. 98 ; La Gaave, viii. b. 96 ; Larche, viii. b. 1900 ; Abriès, viii. m. 1900 (Tutt); Digne, vii. 91 (Lmn.); mtns. of Basses Alpes, rii., $\delta \mathrm{s}$ v. Al. with 3 or 4 eye-spots un.s. h.w. (l'urell); Crissolo, viii. b. 01 (Tutt); Via Mala, vii. 5, 1900; Susa, vi. 21 99, large, with large eye-spots; Bormio and Trafoi (li.-Lm.).

Directions of Yar. (a.) tendency to obsolescence of mahogany patches containing the eye-spots, f.w. and h.w. up.s. culminating in :

var. Valesiaca, Flues: in wh. they are r. slight, the eye-spots also, but not the pupils, being smaller.

Loc. Murren, vii. e. 1900 ( $\left.{ }^{*} h_{\text {. }}\right)$; Dent du Midi, viii. 602 (Fi.s.); Simplon (Far.).

An intermediate form is known as :

var. Pyrenaica, liill: with less mahogany col. than type but more than Julesiaca.

Loc. The usual form in the Alpes Maritiues (lim.); probably the form at Zinal (li.-lim.).

(b.) number of eye-spots; $q$ has gen. a small one above the double one at apex up.s. f.w.; those on un.s. h.w. are often scarcely visible.

ab. \& Aboculata, Far.: without spots f.w. up. and un.s.; h.w. with 2 blk. dots in place of eyc-spots.

Loc. Plateau de Trient, nr. le P'enty (F'ur.).

[Ois.-In Mr. Fison's collection is a specimen with the apical eye-spot con taining 3 wh. pupils.] 

E. Evias, Cimlur (Bonellii, Ml\%); 4 mm. Fi. plt. grasses ( $F^{\prime}(t \cdot)$.

of lighter grd. col. and bands up. and un.s., f. and h.w.

Dist. Char. up.s. f.w. long apical eye-spot with 3 wh. pupils: differs from cintere var. Trimpes, by its far greater size; from Eipistyme (\%-r.), by coll of band f.w.

Loc. In Switz. only in the S. cantons, the Valais, the Cirisons, and Tessin : v.-vii. b. according to altitnde. On all the slopes romnd Martigny, from the foot of the cliff's to the Forclaz, and on the other side of the lihone Valley; Saillon; Sion; Hérémence; Evolena : Nionc, Susillon and Chandolin in the Val d'Anniviers; Baltschieder Valley; (iamsen; Rrig; Mörel; Fiesch; Grengiols, ic. (For.); Pfynwald, vi. 2t.98; Saas Valley towards Almagell, ri. 2491 (Bkim.); Bírisal, vii. b. 01, c., but worn (IVh.); Kermatt, vii. 01 (Lmn.) : Tiefenkasten ('(u/lisch); ur. St. MIoritz, vii. /81, c.

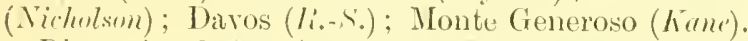

Digne, iv. 2097 ('Tutt) ; v. 2202 (.STopre); nearly over vi. 599 $($ h.-lim.) ; Cascade de Boréon; St. IIartin Vésnbie; Mardone des Fenêtres, \&c. ( $B$ rmu.) ; ('ertosa di Pesio from $2800 \mathrm{ft}$. to $6000 \mathrm{ft}$., vi.vii. 92 (Norris); Courmayenr, vii. b. $/ 02\left(L_{\text {lorre }}\right)$; nr. Aosta, v. 95 (Miss f'tn.).

Directions of Yar. (a.) depth of grd. col, up.s.

(b.) number of eye-spots: sometimes the spot below the triple eye-spot is absent, or represented by a dot ; sometimes the lower one is also reduced to a dot; sometimes a 5th, pupilled on un.s., appear's nr. costa of h.w. in ठ , and in $q$ there are sometimes as many as 6 pupilled spots on each w. up.s. (counting the triple spot as :3).

(c.) distinctness of bands un.s. h.w.

E. Nerine, Fr. (Goante, /I.-S.) ; $48 \mathrm{~mm}$. Fd. plt. (and 1.) unknown.

o nu.s. lighter than 0 .

Dist. Char. oblirque position of apical eyes, and deep grd. col. f.w. contrasting strongly with bancl, in connection with definite ante-margl, band un.s. h.w. (r. sicipio).

Loc. The E. part of the region only (vi.), vii.-riii. Riva, on lake of Garda, from 500ft. to 5000ft. (Vilires); Lago di Loppio, vii. 31, 1900, c. (.tones) ; a mtn. stream above Lismo, viii. 02, r. ab. (1/iss l'tn.) ; Cortina district-Croda di Lago, viii. 7-14 95; Sorapiss, viii. 1295; Val Bigontina, viii. 695 ('Tutt): Mendel l'ass, vii. e. 95, ah. (lum.) ; Isozonthal, nr. T'olmein, vi. 1292 (Korris). Directions of Yar. (a.) tendency to loss of brt. colouring, culni. 
yar. Reichlini, H.-S. (Styx, Fr.) ; larger, duller, bands un.s.

f.w. and h.w. less conspicuous, and without eye-spots un.s. h.w.

Loc. S. Tyrol, e./., Stelvio, New Baths of Bormio, vii. 11, 1900, ab. (li.-lim.).

An intermediate form between licichlini and the type exists.

yar. (? ab.) Stelviana, Cmr (1871), (Italica, Fry, 1880.)

Loc. The Swiss form: an hour behind Zernetz, at Champlong ('uri); nr. Cierfs (Zll.-llolder); in the Tal da Fraele and Val Iuranza ( $/$ ll.-Inolder) ; Monte Grigna, above Lecco (Christ).

(b.) diminution of size, together with increased darkness of eol.

yar. Morula, Smr: with un.s. f.w. nnicolorous, but somewhat lighter' well-defined band un.s. h.w.

Loc. High meadows in S. Tyrol; Grödner Joch; Seisseralp (Kane).

[Obs.-In the Museum at Sion are 2 specimens identified by Standjuss as this var., wh. were taken on the Gemmi by M. Paul.]

E. Scipio, Bste.; 42mm. Fd. plt. (and l.) unknown. o with dk., o with 1t., h.w. mn.s.

Dist. Char. un.s. h.w. nearly unicolorous in connection with lt. chestmut disc un.s. f.w., and large wh.-pupilled apical eye-spot f.w. up. and un.s.

Loc. Basses Alpes, vii. m., viii.; Digne, the Dourbes, vii./91 (Lmm.) ; Draix ; Beauvézer; Seyne ; Allos (l'orell) ; Larche, viii. 1-4, 1900 ('Tutt) ; Barcelonette; Ozglosse; Malmorte (Kane).

Directions of Yar. (a.) presence of eye-spots, 2 or 3 , ul).s. h.w.

(b.) occasional presence of eye-spots un.s. h.w. in $\delta$.

(c.) presence or alsence of blk. dots representing eye-spots un.s. h.w. in $q$.

(d.) mo.s. h.w. cl. bant occasionally just visible.

E. Euryale, lisp.; $40 \mathrm{~mm}$. Fd. plt. a great variety of grasses $(F a r$.).

[Obs.-The number of contlicting descriptions of Enryale and Adyte, including those which make Alyte a var. of Euryule, and those which make Luryale and its vars. to be vars. of Ligeu, and the way in which most of these descriptions fail to fit in with facts, are positively distracting. On the whole, the preponderance of opinion seems to be in favour of regarding Euryale as a distinct sp., though I am not sure that this is corlect. The whole matter reguires further investigation, and the arrangement here adopted is merely tentative.]

o with much more conspicuous lt. ante-margl. band un.s. h.w. tban $\delta$.

Dist. Char. 1t. ante-margl. band, or traces of it, un.s. h.w., with a tooth cutting deeply into the middle of the dk. centre. 


Loc. Gen. ab. in the Jura and the Alps, vii.-riii., extending in the S. to the Alpes Maritimes, and in the E. to the Styrian and Carinthian Alps.

Directions of Yar. (a.) entire absence of wh. pupils in eye-spots. (b.) diminution of red-brn. band up.s., culminating in :

ab. Ocellaris, Styr.: in wh. it is reduced to small patches.

Loc. Canton Glarus (Christ); Larche, riii. b. 1900, as ab. (Tutt); Heiligenblut, with type, vii. 28/97, c. ( $\mathrm{Lmm}$.)

(c.) obsolescence of blk. spots on red. band, culminating in :

ab. Euryaloïdes, Tenyström : in wh. they are almost extinct up.s. f.w.

Loc. Toblach, viii. 4/95; Cortina district-Croda di Lago, viii. 515/95; Cristallo, viii. 8/95; Falzarego Pass, viii. 695 ; Val Bigontina, viii. $1195(\mathrm{Tutt})$; Heiligenblut, vii. $2497\left(\mathrm{C} / \mathrm{H}^{\prime}\right)$.

(d.) presence or absence of eye-spots un.s.h.w.

(e.) distinctness of lighter ante-margl. band un.s. h.w. in ơ ; gen. r. inconspicuons, exc. the "tooth."

(f.) col. of it. ante-margl. band in $q$ un.s. h.w., gen. whitish, but sometimes yell., forming :

ab. I Ochracea, $W \%$.: Dr. Spuler speaks of this as if it were a $r$ scarce form; on the Simplon it is the usual one.

(g.) un.s. dusted with wh.

ab. Philomela, Esp.; wh. is without eye-spots un.s. h.w.

Loc. Gurnigel, ab. at about $4500 \mathrm{ft}$. $(+\mathrm{rey})$.

[Obs. - Frey mentions a fine hermaphrodite, left side $\delta$, right $q$, wh. he took on the Maloja, vii. $/ 65$.

E. Ligea, L. (Alexis, Lsp.) ; $47 \mathrm{~mm}$. Fd.plt. Millimm, ic.

o with much more conspicuous series of eye-spots un.s. h.w. than ठ.

Dist. Char. un.s. h.w. a wh. curved wedge ahout middle of costa (r. conspicuous on dk. ord. col.) often continned as a brokien band more or less across the w.

Loc. Distributed throughout Switz. and Saroie at low elevations but commoner in the $\mathrm{N}$. than the S. In some places it is to be found at over 5000ft., e./., Mürren, vii. e. viii. 1), $1900\left(\mathrm{~W}^{\prime} \%\right.$.); in the lowlands it emerges vi. in.

Less c. and more local S. of Switz., Bourg d' Oisans, viii. m. 96; Abriès, viii. m.1900 (Tutt); Digne; St. Martin Vésubie (Poutell); Pré St. Didier, viii. b. 98 (Tutt); Certosa di Pesio, not uncommon, 
vii. m., \&c. (Nurris); 'T'rafoi, scarce (Frey); Croda di Lago, viii. 91395 ; Sorapiss, viii. 1095 ( $\left.T_{t} t t\right)$.

Directions of Yar. (a.) size and number of eye-spots.

(b.) extent of wh. band un.s. h.w.

(c.) conspicuousness of lt. band containing eye-spots, un.s. h.w.

(d.) breadth of red-brn. band up.s. esp. h.w.

The diminution of all these characters, exc. sometimes the 3rd, culminates in :

var. Adyte, Hb.; the small $\mathrm{mtn}$. form, in wh. the eye-spots are often unpupilled up.s. on f.w.; always exc. at anal on h.w.

Loc. Gen. distributed over the higher alps, but not, as a rule, so c. as Euryale, vii.-viii.

[Obs.-The confusion existing with regard to these $2 \mathrm{sp}$. make locs. unreliable but both are widely distributed, and gen. occur together.]

E. Ethiops, Esp. (Medlea, II\%.; Blandina, Fullir); $44 \mathrm{~mm}$. Fd. plt. Pon annua, Dartylis ylomerata, Ayrotis canina.

q lighter than $\delta$, esp. un.s.; band up.s. f.w. led-brn. in o , or.-bru. in $q$.

Dist. Char. broad bands un.s. h.w. in connection with conspienous eye-spots up.s.; differs also from Promori in having chestnut band un.s. f.w. well defined interiorly.

Loc. Probably the commonest and most widely spread Erebia, both in latitude and altitude; vii. e.-ix. m. Throushont the region, exc. possibly the $\$$. French Alps. It is reported as c. from Thorenc and Tanlanne by Villiere, and also from St. Martin Vésubie: and though some donbts have been expressed on the subject, it seems unlikely to be incorrect, esp. as it is certainly to be taken on the E. slopes of the S. Alps; Certosa di Pesio, viii. 92 (Norris).

Directions of Yar. (а.) size: $38 \mathrm{~mm}$. (Jura), $50 \mathrm{~mm}$. (Aigle).

(b.) size, distinctness, and number of eyespots. The form of the $\delta$ in wh. the band up.s. h.w. becomes obsolete is called :

ab. Obsoleta, T'utt. The other forms are unnamerl. They are: б, ир.s. f.w. $2-5$, gen. 8 or 4 ; h.w. $0-5$, gen. 3 ; un.s. f.w. :3-5, gen. $:$; h.w. $2-5$, gen. 3 ; 9 up.s. f.w. $3-6$, gen. 3 or 4 ; h.w. 3-61, gen. :3 or 4 ; un.s. f.w. 3-5, gen. :3 ; h.w. 3-5. gen. : or 4 . The spots un.s. h.w. are often v. indistinct.

ab. Inæqualis, Mousley: in wh. the number of spots on right and left ws. is different.

+ Note. In the only specimen I possess with 6 spots up.s. h.w. the top spot is red-b'n., wh.-pupilled, but without any blk. ring. It was taken at Aigle. 


(c.) tendency of band mp.s. to break up into rings, forming :

ab. of Nigra, Mousley: the grel. col. heing r. dk.

[Obs.-Ona suspects this to be a duplication of - Fthiops.]

ab. \& Pallida, Monsley: the grd. col. being lighter and greyer.

(ג.) tendency to become lighter in band up.s. $q$, culuinating in :

ab. F Flavescens, Tutt: in wh. it is pale yellowish.

(e.) distinctuess of bands un.s. h.w. Specimens from hot loes. such as Aigle (II\%.) ; Susa (l'utt); Certosa di l'esio (Norris), have the bands strikingly developed in the $q$ but less so in the $\sigma$; specimens from the Jura (Vallorbe), though small, have the bands $v$. strongly developed even in the $\delta$. On the other hand the bands are almost obsolete in specimens from the highest min. loes., constituting:

ab. Stricta, Mousley; wh. has also the band un.s. f.w. indistinct, and the spots v. small.

Loc. Bérisal, Zermatt, Mïrren, \&c. (W\%.).

(f.) tint of grd. col. un.s. h.w., wh. varies immensely even in the dk. bands; the normal tint of the lt. bands is gr., this, however, is often replaced by other cols., esp. in $q$.

ab. Leucotænia, Ntrlr. (Neoridas, lrr.); bands almost wh.

ab. Ochracea, Tutt; bands ochreous yell.; a v. common form in $q$.

ab. Violacea, $\| \%$. bands various shades of heliotrope, c. in a darkish shade in of, and a pale shate in $q$, r./., at Aigle, and sometimes in the Jura in a pale shade in of also.

E. Neoridas, Biscle.; 10mm. Fid. plt. I'ou cumun, I'anicum sonyminale.

o lighter than $\sigma$, esp. un.s. h.w.. and with larger and more conspicuous eye-spots.

Dist. Char. curiously truncated appearance of f.w. (otherwise not nulike, Ethiopss).

Loc. Dauphiné Alps-Sassenage, viii. 21,95; La Grave, riii. b. 95; Bourg d'Oisans, viii. m. 95; J'jourg d'Aru, viii.111. 95 (T'utt); throughout the Hautes Alpes, Basses Alpes, and Alpes Maritiucs, from about $2000 \mathrm{ft}$, vii. e. and viii., gen. ab. (I'orell); Larche, viii. b. 1900 ; Barcelonette, viii. b. 1900 ; Abrics, viii. 111. 1900 ; Pielmont-Susa, viii. 5-17/97 (Tutt). 
Direcuions of Var. (a.) occasional extra eye-spot between the twin apical spot and that $\mathrm{nr}$. anal. ang. up.s. f.w.

(b.) conspicuonsness of eye-spots up.s. h.w. ; sometimes almost absent.

[Obs.-Specimens from Digne are larger, lighter, and rather less strongly marked than those from mins. (Powell).]

E. Pronoë, E'sp. (Arachne, Hh.) ; 42mm. Fil. plt. l'on, \&c.

T. dk. brn., with 2 wh.-pupilled apical eye-spots, and one small one nr. anal. ang. in chestnut band, up.s. f.w. ; q un.s., esp. h.w., lighter than $\delta$, and with yell. tint in lt. bands f. and h.w.

Dist. Char. a purplish tinge nr. apex f.w. and all over h.w. un.s. in $\delta$; on costa, mr. apex f. and h.w., and on nervures h.w. in 9 .

Loc. The E. form, Austrian and Styrian Alps (reported also from Mt. Cenis, Kane). [Specimens taken by Mr. Fison at the Fiesch Glacier approach v. closely to the type.] vii. e. and viii.

Directions of Var. (a.) number of eye-spots up.s. h.w.; 3 or 4 , occasionally more in $q$.

(b.) un.s. f.w. presence or absence of $3 r d$ spot.

(c.) depth of grd. col. un.s. h.w. and consequent conspicuousness, or the reverse. of bands.

(d.) tendency to disappearance of eye-spots and bands, culminating in :

var. Pitho, $I 7 b$. : gen. with 2 inconspicuous apical eyes up.s. f.w.

Loc. Gen. distributer over the higher Alps of cantons St. Gall, Appenzell, Berne, Tand, the Talais, and the Grisons (Frey); r.t., IVeissenburg, v. c. (H/\%); Mür'en, vii. 89 (Lmm.) ; Rochers de Naye, ix. 7, 1900 ; Steinenalp, vii. e. 99, and above 5th Refuge on the Simplon Road, viii. m. 98 ( $\mathrm{W} /$.); Pont de Nant, vii. 27, and viii. 1 (l;l.) ; road S.IV. of Châlet Richard, above les Plans, viii. 10.91, ab. (Fis.) ; Pilatus (Kans) ; ic.

Dôle and S. IV. Jura (Fry); Toblach, viii. 295 ; Cortina district Sorapiss, viii, 1295; Croda di Lago (with more typical forms), viii. 5-1395; Nouvallo, viii. 7.95 ; Falzarego Pass, viii. 6.95 (Tutt) ; Cortina, vii. 1900 (.Jones); the Stelvio, vii. e., and Brenner, vii. 27, 1900, v. ab. (R.-lim.) ; Campiglio, vii. 95 (Lmn.).

[Obs.-There is a marked difference between specimens from the Simplon and from the Rochers de Naye; the $\delta \mathrm{s}$ from the Simplon have much more distinct patches up.s. f.w., and sometimes races of them on h.w.; bands f. and h.w. un.s. v. marked, and 2 wh.-pupilled apical eyes un.s. f.w. with often a 3rd anpupilled : those from the Rochers de Nage have far less conspicnous bands un.s., and are often withont apical eye-spots, or only one, up. and un.s.; the bands and eye-spots of $q \mathrm{~s}$ are, however, v. distinct.] 


E. Epistygne, Hh. (Strgne, Fr.) : 42mm. Fd. plt. (and l.) unknown.

o lighter than $\delta$.

Dist. Char, ochreons band, and small costal blotch nr. base.

Loc. The S.E. Alps of France. Hautes Alpes (Kane): Digne, ir. e. 97, worn; had been ab. on the Donrbes iv. b. ('intt) : iii. 20 94, and a few worn specimens $\mathrm{r}$. b. (Jomess); Nontagne de St. Vincent, iv. 98, c. (Lang) ; iv. 7 02, scarce (H.-1im.) ; between ri. 9, and rii. $289(1 / / s$. Nichull $)$. Alpes Naritimes, Thorenc, v. (Pourell); above Grasse, iii. m. 97, but not out at that time in 1900 and $01((\% \mu$.$) ; ir. 50 03$ ('Tutt) ; above J)ragnignan, iii. :30 0:3 (lientall).

Obs.- This is not the only record for oly ; there must, at any rate in some years, be a partial 2 nd brood; this with an insect of such early emergence is only to be expected.]

Directions of Yar. (a.) 2 or:3 pupils to apical eye-spot.

(b.) number and distinctness of other eye. spots.

(c.) more or less marked bands un.s. l.w.

E. Goante, Lisp. (Sciea, //l.) ; 44mm. Fr. plt. grasses (Fiar.).

o lighter than $\delta$, esp. un.s. h.w. in which the markings are brn. the nervines wh.

Dist. Char. nn.s. h.w. Ilk. mottled basal lialf, gen. followed by lighter elging towards out. marg.; distinguisher from Gury by greater size and by lt. band nn.s. f.w. being more conspicuons.

Loc. The Alps of cantons Berne, Glarns, St. Gall, Appenzoll, the V'alais and the Grisons, vii.-viii.; P.!.., Adelboten, viii. 10, 1:)0()

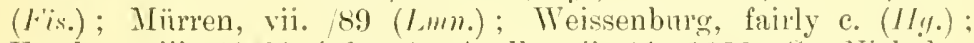
Forclaz, viii. 1901 (slopwr) ; Arolla, vii. 11, 1900; St. Nicholas, vii. 1, 1900 (B/km.); Gornergrat, viii. 1001 (Sloper); Bérisal, viii. 97; rii. 98, \&c. v. с. (I\% \%) ; helow Simplon village, v. c.:

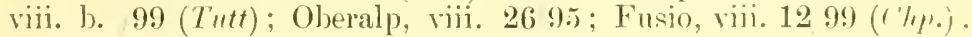
Pontresina, vii., Thusis, viii. 95 (1/iss l'tn.).

('hamonix, viii. e. 01 (sluper); Negève, viii. b. 02; The lirivent, viii. m. 02 ; Bourg d'Oisans, viii. m. 96 ; ahove Lanslebonrg, viii. b. 97 (Thutt); in the Irasses Alpes; Draix, leanuézer, Seyne, Allos, Faillefen, vii. e., viii. (Pomenl) : Certosa di Pesio, s. ab. on the Passo Babane, and in the Yal Margntreis. viii. 92 (Norris); Courmayenr, viii. b. 94: Yal Yóni, viii. on. !94: Cogne, viii. b. 94: Jobbie, riii.m. 01; An Pra, viii. e. (01, small (T'utt); S'telvio. from below Trafoi to Gomagoi, vii. 1900) Brenner. vii. 27, 1900 (li.-lim.).

Directions of Var. (а.) size : from :37mm...

(b.) conspicuonsness of band un... f.w.

(c.) occasional extra eye-spot hoth above and below the normal :; up.s. h.w. 
(1.) amount and clearness of markings m.s. h.w.

(e.) number and clearness of eye-spots mn.s. h.w. : 3.5 ; gen. 4.

Obs.-The un.s. h.w. is r. variable; in some $\delta \mathrm{s}$ almost unicolorous; in some with v. pronounced lt. band: in some os with $\mathrm{v}$. brn. sheen on out. marg., and v. broad wh. hand; in some the eye-spots are v. distinct, in others almost invisible.

\section{E. Gorge, Esp.: :36mm. Fil. plt. grasses (Fir.).}

o slightly larger and rather lighter than z , esp. mn.s. h.w., wh. is also rather more marked.

Dist. Char. nn.s. h.w. mottled v. dk. brn. or blk, with cl, band (i. Goante).

Loc. In Swit\%. with the same range as rononte, but at higher elerations and coming rather further TW., p.\%., Grand Moreran, vii. 11 ( $/$ il.); above Engelbero ( $($ hrist); Arpilles; liovine: (ilacierde-Trient; above Fully : and other heights round Martigny ; between Loèche-les-bains and the (iemmi; Mayenwand; Aletsch Glacier; Bortelalp, ke. (Far.) : Arolla, vii. m. 1900 (Him.); top of Tal d'Anniviers, viii. b. 01 : Saasthal, viii. b. 97 (li.-lim.); Simplon Pass, above 5th Refuge, vii. 1:301 (I/\%); the Furka and the Faulhom, vii. 89 $\left(\mathrm{l} m \mathrm{~m}_{\mathrm{o}}\right.$; Fluelathal, vi. 2801 (Fis.) ; Andermatt, riii. 19.95 : Gnarda, vii. e., 1900; Pontresina, vii. 7.21, 1900 ( ( $/ \mu^{\prime}$.); m. Rernina Hospice, vii. 9) 01 (Fï.) ; Henthal, c. (Nirholson).

Extenting to extrene $S$. of region ontside Switz., e.\%., Le Lantaret, vii. e. riii. b. 96; ('rête de Reychasse and Pointe de Lanze. viii. m. 1900 (T'utt): ('ertosal di l'esio, vii. 92, c. (Norris); St. Martin V'subie; Faillefen, de.. vi.-viii. (lonell): The Grammont. viii, b. 91: Cortina district-Xouvallo (Nuovalo), viii. 1:3 95; ('rorla di Lago, viii. 9 95; Palzarego Pass, viii. 69 9: ('Tutt): Campiglio, vii. m. $9\left(0\left(1 / 1 \mu^{\prime}\right)\right.$.

Directions of Var. (a.) tint and conspicnonsness of markings in.s. h.w.

(b.) temlency to disappearance of eye-spots up.s. f.w., culminating in :

ab. Erinnys, Fis.: in wh. "ven the apical eyes have almost (or quite) disappearerl.

Loc. Gen., but not exclusively, in the W. part of the region, with type; high above, th liefuge on the simplon, viii. 5 99, rather

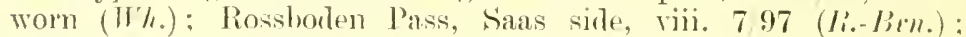
Rosegg (Glacier, viii. : 01 (Fi...) : Andermatt, viii. e. 95; Guarda, vii.e. 1900 , a few ( $\%$ \%.); Gornergrat rii. 10.95 (F'is.); viii. 1001 (Slopere).

liasses Alpes and Alpes Maritimes (I'rurll); The Grammont, viii. b. 94; ('rota di Lago, viii. 9 95: Falzarego Pass, viii. 6.95 $($ ('intt).

[Obs.--In intermediate forms the eye-spots below the apieal, and the 2nd anpical spot are wanting. 


(c.) elongation of apical spot, in which is a 3rol wh. pupil.

var. (\& ab.) Triopes, cym., in wh. the other eye-spots f. and l.w. are gen. mole conspicuons also.

Loc. The usual form of the li. part of the region; Piz Lan-

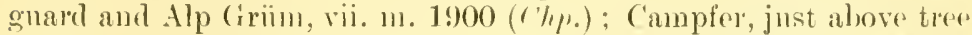
limit, ab. (./omes); Pontresina, vii. 9) (.Miss l'tu.); Roseggr (ilacier, riii. 9) : Remina Pass, viii. 3001 ; Flnelathal, vi. 2801 $(F \%$ is.). In the last the type was much more nsual.

Stelvio from top to Franzenhöhe, v. c., vii. 12, 1900; Brenmer',

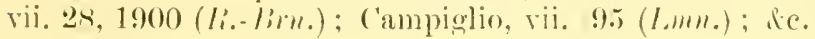

\section{E. Tyndarus, lisp. : $320 \mathrm{~mm}$. Fil. plt. grasses.}

of lighter than of, gen. with m.s. h.w. much more conspienously marker.

Dist. Char. np.s. v. strongly market with metallic sheen of grm. and prp. This occurs also to some extent in other' sp., r.\%.s lalymene, cionte, Alecto, but not nearly so conspicuonsly.

Loc. Absent from the Jura, but otherwise $c$. throughout the region from the Alpes Maritimes (I'murll), amel Crrtosa di l'esio (. Imris) to Heiligenblut in (arinthia $(l, m n$.) : often $\mathrm{r}$. ab) : vii.-viii.

Directions of Yar. (a.) tendency of the 2 mall appeal eyes to lose the pupils, and

(b.) to disappear, culminating in :

ab. Cæcodromus, Guinie: wh. is entirely withont.

Loc. Zermatt; Thion-snr-Sion ( '/hist); Bérisal, vii. 99) (II'/.); Arolla, viii. m. (9) (Twtt); ()heralp, viii. 25 95 ( $1 \%$ h.

Mont de la Saxe, viii. b. 94; Penegal, viii. 1 !s ('Thtt).

(c.) tendency of apical eyes to become larger and more comspicnons, colminating in :

yar. (\& ab.) Dromus, /I.... (Pyrenaïea, /l!me); wh. has also an ante-margl. row of wh.-pupiller eye-spots in ik. mahogany rings mp.s. h.w. ; it is larger than the type.

Loc. Cliffs at the Rochers tes Vents above Gryon (Knecht):

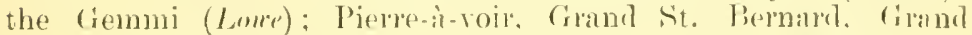
Ferrex, (iomergrat $\left(F, r^{\prime}\right)$; in these locs. as an ab.: Mirren. viii. b. 1900 , here the only form $(\mathrm{I} \%$.).

Le lantaret, viii. b. 96; Mont de la Saxe, viii. b. 94; Val Véni, viii. m. 98; An Pra, viii. m. 01 ('t'utt); Meiligenlut, vii.

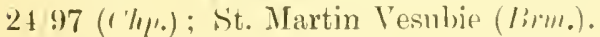

Obs.-In Switz. the chestnut markings are not so hre as in the Spanish specimens.]

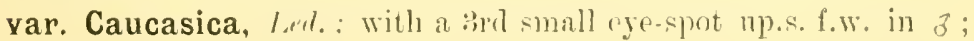
h.w. like llrmm!s. 
Loc. Mt. linet (livit:rer).

Obs. - 1 have a ofrom Mitiren with a Bril spot up.s. f.w.

(ג.) distinctness of markings mu.s. h.w.

[Obs.- Tar. Tromus o often has un.s. h.w. almost micolorons lt. or., only dusted with yell.-brn.]

E. Lappona, Lisp. (Manto, Fillr.); $41 \mathrm{~mm}$. Fil. plt. grasses ( 1 (1) . .

o rather smaller than $\delta$, and lt. band up.s. f.w. more con. spicnous.

Dist. Char. up.s. f.w. 4 blk, dots on inconspicuons lighter band: grit. col. un.s. h.w. gle.

Loc. Like Tymulars absent from the .Jura, but otherwise distributerl over all the higher alps, though not gen. nearly so ab. as l'yndarus: it is reported from all parts of the region from the Alpes Maritimes, vi. e. and vii. (l'mell); and Certosa di Pesio, vii. (Norris); to Stelzing vii. 11, and Heiligenblut, vii. 25 (l.mm.); vi. to viii., according to altitude, ".!., Rocher's de Naye, vi. 3, 1900; Simplon Pass, vii. m. 98 ; ahove Wrasen, viii. b. 98 (I\% $\%$.).

Directions of Yar. (a.) tendency of dk. transverse lines un.s. h.w. to obsolescence, culminating in :

ab. Pollux, Eisp.: which is without them.

Loc. Rochers de Naye, vi. 3, 1900, the usual form (II.); Rossinières, summit of Mt. Cray, vii. 6, 1900 (Blim.) ; Anthémoz, Dent ru Mirli, vii. 2902 (Fis.), \&c.

Passes Alpes and Alpes Maritimes (l'owrll); S. Tyrol, vii. 95 $(\mathrm{l}, \mathrm{m}, \mathrm{m})$.

Oobs.-On the other hand these dk. transverse lines sometimes include a darker band. In Mr. Fison's collection in a female wh. he took on the Grimsel, with v. dk. el. band min.s. h.w.

(b.) tendency to lose in adilition the darker transverse lines up.s. f.w., culninating ii) :

ab. Sthennyo, riraslin: wh. has only the blk. rots in chestnut jings.

(c.) Loss of the bik. dots, v. frequent on un.s. h.w., and culminating in :

ab. Cæca, Far.: in wh. they are absent $f$. and h.w., rp. and in.s.

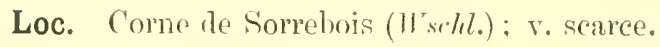

Sub-Fam. IFLANARGIINA.

Genus, Melanargia, Mrigrn (Arge, momm manculmulnm. /17.).

Prevailing col. blk. and wb. marbling; hyb. . 




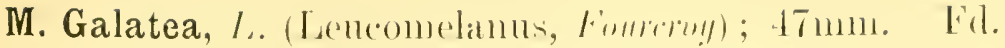
plt. I'hlumin frutense, and other gratsses.

o up.s. whiter, un.s. yellower than $\delta$.

Dist. Char. 111... h.w. cl. band tilled in with dk. col.; eye-spots up.s. f.w. ynite inconspicuous.

Loc. Ab. in one or other of its forms throughout the whole region in the lowlands and on the lower shopes, and monnting in some places to it height of $6000 \mathrm{ft}$; r. r1.-viii, but in N. Swit\%. not appearing before vi. m. In many locs. it toes not reach above $3500 \mathrm{ft}$.

Directions of Yar. (a.) decrease in amount of blk. "1p.s.

(i.) apex f.w., sometimes allowing the blk. apical spot to show conspicuonsly.

(ii.) out. marg. h.w., sometimes allowing the eye-spots to show distinetly.

(b.) entire absence of eye-spots.

ab. Galene, r)hs. (Stgr., f'at., 1901, gives it without loc., implying "anywhere with type." I have never come across it.)

(c.) increase of blk. 11p.s.

var. Galaxæra, lisy.: wh. spots in border much decreased in size.

Loc. A r. usual form in the hotter parts of Switz., the Rhone Valley, Tessin, and the S. of the Grisons.

yar. Procida, H/bst.; still mole blk.; the other blk. markings encroaching on the wh. as well as the border.

Loc. In Switz. only as an occusional ab., e.\%, Lugano, 1. 25.96 (F'is.), but replacing the type in the Basses Alpes and Alpes Mari. times; also found in the Tyrol, e.!., Botzen, vi. e. 01 (Imine).

(d.) col. of $111 \mathrm{~s}$.

ab. क Flaya, Tint: with brt. or.-yell. gred. col.

ab. Leucomelas, Esp.: wh. grd. col., and warkings only slightly darker.

(e.) blk., even of antennic, replaced by rich tawny-bin.

ab. Fulvata, lome: with grd. col. warm primrose-yell.; un.s. lighter.

Loc. Martigny, vi. 25, 1900 $(\mathrm{l}(\mathrm{m} r)$; in this specinen the $1 \mathrm{t}$. and dk. are disposed much as in l'meidu.

M. Lachesis, ///, ; 52 211111 .

Dist. Char. L.w. with single blk, line along fringe, in connection with absence of blk. at bases mp.s. exc. along inn. marg. f.w.

Loc. Reported from bex in the linlletin de la sincité lintumm. loyginge suisse, vol. ix., no. 2. 
Ohs.--Two specimens were taken by $\mathrm{M}$. Borel, one of wh. I have seen. It is undounterly lachesis: M. Borel's collection consists only of a few calses of insects taken by himself in the neighlromrhood of bex, so that there is no posisbility of mistake as to loc. He hals trequently searched the same spot since, bnt in vain. His own view is that the specimens had been bred in catptivity, and hat either escaped or been set free.

M. (Iilprgia, ('yrilli); var. Cleanthe, lisele: lighter than type; 5ximm. Fid. plt. Lamartia anra, and various griasses.

Dist. Char. In.s. L.W., cl. band ontlined in r. lk. col.

Loc. J)igne, viii. e. (1/r.s. Vir/mll).

M. Syllius, //hst. (Poyche, /H. : Arge oecitanical, Lisp.): $521 \mathrm{~mm}$. Fd. plt. Sirach!ypatium pinnatum.

o slightly larger than $\delta$.

Dist. Char. un.s. h.w., nervures, and deep margl, dogr-toothing, yell.-linn.

Loc. Alpes Maritimes, Villefranche, (iorge of St. Andre, dic. (hrm.): S. side of simplon Pass (han'); r.ri. At Hyères as

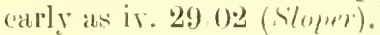

Directions of Var. (a.) number of eye-spots li.w.; normully 5.

ab. Ixora, lisele: is entirely withont.

Sometimes a small spot appears in the nsmally empty interneural space ahore the $:$ lower eye-spots, up.s. or un.s. or both. In

ab. Sexoculata, Slun'r: this is replaced on uns. by a large eyespot.

Obs. - Mr. Fison possesses one of 2 specinens wh. purport to have been taken at Chiteau doex. After making such enefuiries as were possible, it seents that the only possible alternative was that they were received from freece. If this is correct, Chiteau d'Oex is probably the less unlikely loc., but the evidence is quite insufficient to admit it to the swiss list.]

EliliA'TA.

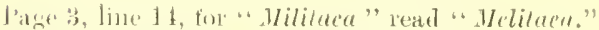

J'age !. line 26 , delete "Entomologist."

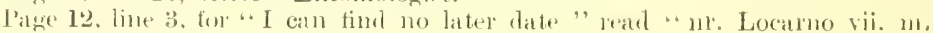
$10: 3\left(F \% i_{.}\right)$.

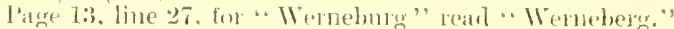

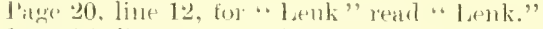

linge 54, line 29. tor "hyb. 1." reatd "h hil, p."

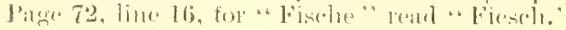

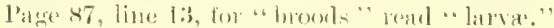

l'age 120, line 27, for "Leuk" real "Lenk.' 



ABERRATIONS.

HESPERIIDES.

HESPLRIHD.J'.

Histentis.

Hislitilut.

Carcharodus, $\mathrm{Hb}$.

I aratera, Es]

Althaew, Hb. rer, Butica, Rimbr. . . . 2

Alcrex, Esp.

"rer". Austrulis, \%ll. .. . . 3

Hesperia, Fabr.

* Sirke, E-j.

*al, Onopordi, H.-s. ..

Carthani, Hb. . . . rus. Valesiaca, strecker

Alvens, $\mathrm{Hb}$.

rav. Onopordi, Limbr.

inr. Cirsil, Rumbr. . .

*iar. Conyzat, Gurinfe

c(t). Fritillum, Treitschke

recr. Carline, Rimbr. .

Serratule, Rimbr.

al. Creca, Frr.

ab. Tarasoides, Häfné

Caculie, Rmbr. .. . .

Andromeda, Wallengren

Centaurese, limbr.

Malvie, L. . . .

(1). Fasciata, Tutt

(b). Internedia, schilde

al. 'Taras, Brgstr. . .

*b. Malvolides, Elwes

Pyrgus, $\mathrm{Hb}$.

*T'essellum, Hb. . . . . . . 7

*1'roto, Esp. . . . . .

4Orbifer, Hb. . . $\quad$. $\quad \ldots \quad 7$

Saо, Hb... . . . . . .

*ai). Eucrate, Ochls. . . . . s

Nisoniades, Hb.

'lages, L. . .

ab. Approxinata, Lowe

l'A.MHHLIx.k.

l'A.HIHLLIH.

Pamphila, Fur.

sivivanus, Esu.

Cummu, 1 . ab. Caterla, stgri. $\quad \ldots \quad \ldots$ !) rar. (?) Alpina, Bath .. . . y ab. Flava, 'Tutt $\quad . \quad \ldots$ y

Thymelicus, Hb.

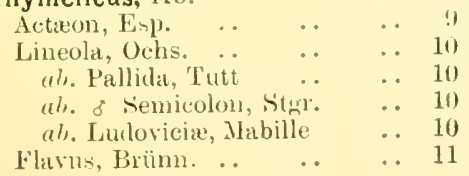

Crenolin.

Carterocephalus, Led. Lalamon, Yallas..
* Siylvius, hinoch.

1.Mil.

Heteropterus, Duméril

Morpheus, Pallas

\section{PAPILIONIDES.}

LIC.FIIIA.

LXe.:N11,1.

Lyc.lisis.l.

Tinctionili.

Thestor, $\mathrm{H}$ h.

*Ballas, liabr.

Chrisollitilu

Chrysophanus, $\mathrm{Hb}$.

Virgaurew, L. .. . . . . I: car. Zermattensis, Fallou .. 13

(I)ispur, Haworth)

*ar. Rutilus, Werneberg. . . 1:;

Ther-amon, Esp. _ . . 1:;

*ver. Omphale, Klov .. .. 11

"Hippothö̈, L. .. . . . . 11 itr, Eurybia, Ochn. .. .. 1t

(1). \& Nigra, lat. .. . 15

ab. Contluens. Gerhard .. 1.)

ai). Stieberi, Gerhard .. .. 15

Alciphron, Rott. . . . . . 15

var. Gordius, Sulzer .. .. 15

ab. \& Midas, Lowe (11. ab.) .. 16

Dorilis, Hutn. .. $\quad \ldots \quad \ldots 16$ ab. Nana, Wh. (11. ab.) .. 17 ab. Purpureopunctata, Wh... 17 car. Subalpina, Spr. .. .. 17 car. Brumnea, Whi. .. ... 1s

l'hlueas, L. . . . . . . . 1s al. Interinedia, Tutt .. .. 1s (1). Schmistii, Gerhard .. 1s ai). Suffusa, Tutt .. .. Is (1). Eleus, Fabr. _. .. 1:1 ab. Caeruleopunctata, Stgr. . 1! ab. Obsoleta, Tutt .. .. J!) ab. Rudiata, Tutt .. . . 1!)

Amphidamas, Esp. . . . . 1!

LYCENIDI.

Lycæna, Fabr.

Alcas, liott. .. . . . . . 20

ab. Minol, Räizer .. . . 20

Euphemus, Hb. . . . . $\quad \ldots \quad: 0$

Aleon, Fabr. $\quad \ldots \quad \ldots, \quad \ldots \quad 20$

at". Monticola, Stg1... .. 21

ab. o Nigra, Wh. (11. ab.) .. ㄹ1

Arion, 1... cai, Olsceura, Christ .. .. …

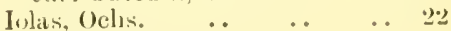

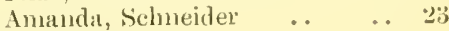

Cupido, Schrank

Nininna, Fissl. .. . . . 21

ior. Montana, Fiey .. .. 2I

ver. Alsoidles, Gerhard .. 24

ub. Pallida, Tutt .. .. 2t

ai. Obsoleta, Tutt .. .. $2 . t$ 
*Lolquinii, H.-.

Seluru, Bsily

Nomiades, $\mathrm{Hl}_{1}, \quad \cdots \quad \ldots \quad \ldots$

Semiargus, Pott. . . .. . . . .

eur. Montana, Frey $\quad \ldots \quad$ ․

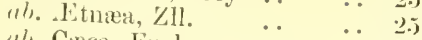

al. Cacca, Fuch. $\quad \ldots \quad$ ‥

al). Striata, Ith. (11. ab.) .. 25

Cyllarus, liott. …

ah. Blatchieri, Milliere $\quad \cdots 2^{-}$-

ub. Tristis, Gerhald .. $\quad \ldots \quad 26$

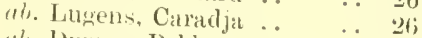

al. Dymus, Brlih. $\quad \ldots \quad$..

ah. Subtus-1akliata, Obth. .. 26

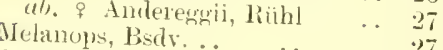

Polyommatus, Litit.

Emmedon, Esy. . .

ab. Subtus-impunctatu $\cdots 27$

ab. Sipeveli, Husz

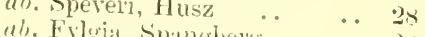

I) (nuze lii, lisdy a $2 x$

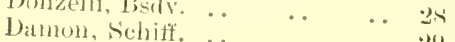

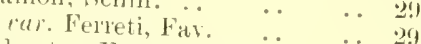

(Aonetris, Esp.)

"car. lipppertii, Lsdr... .. 30

* Dolus, Hh.

Meleager, Esl. . $\quad \ldots . \quad \ldots 30$

al. o Steeveni, Treitschlie - 30

Corydon, Porla .. ai). Calydoniu, Lowe (n. ab.) 31

(? ab. Hispana, H.-S.) .. .. 31

ab. क Semibrumnea, Milline

al. i Syngrapha, Leferstein

al. Aurantia, 'Tutt

$\cdots \quad 31$

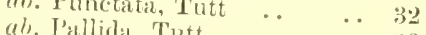

… $\quad 32$

al). Striata, Tutt

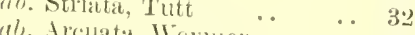

Bellatwus, liott. . 32

enr. Adonis, $\mathrm{Hb} \quad \cdots \quad \ldots 32$

ul). Pallida, Tutt

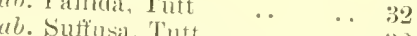

4b.

ab. Cinuides, Steri .. . 32

(1). Obsoleta, Tutt $\cdots \quad \ldots 3:$

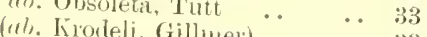

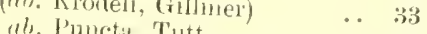

*al. Punctiferu, Ohth $\cdots \quad \ldots 3: 3$

al. Striata, Tutt

Hylas, Esp

ab. Niqropunctitit $\ddot{\forall}$. 33

atb.) ... (11.

( ${ }^{*}$ ) ab. Adderidit, Tutt $\quad \cdots \quad \ldots 3 t$

ab. Minor, Tutt = $\cdots \quad \ldots \quad 31$

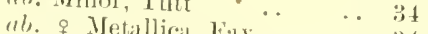

Escheri, Hb.

ab. Punctulatil, Wh. (u, $\cdots 34$

. (11.4h.).. 33

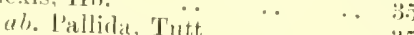

al. Clara, Tutt . . . 35

al). o Carulescens, ih. $\because 3.5$

ab.) $\ldots$ al. ? Carulen, Fuchs riges.

ul. I Icarus, Rott. .. . . 36

ab. \& Semiclala, Tutt $\quad$.. 36

ab. \& Angulata, Tutt $\quad$. 36

al. Iphis, Meigen .. .. 36

ul. Icarinus, Scriba $\ldots$.

ab. Semipersica, Tutt $\quad \ldots 36$

ab. Persica, Bienert .. . . 36;

(1). Areua, Far. $\quad$. $\quad \ldots .36$

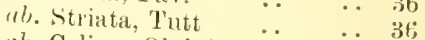

*(? ab. Celina, Obth.) ‥ $\quad \ldots \quad 36$

Elos, Ochs. $\quad \ldots \quad \ldots . \quad \ldots \quad 36$

ab. L'etrividenda, Fax. $\quad \cdots \quad 37$

al). Subtus-radiata, Obth. $\ldots 37$

Orbitulus, Prumner $\quad \ldots \quad \ldots 37$

ah. Subtus-punctis-fortissimis,

Fav. .. $\quad \ldots \quad \ldots . \quad \ldots \quad 37$

al. Aquilonia, Lowe (n. ab.) 37

Astrarche, Brostr. ... .. 3s

ab. Allows, Hb. $\quad \ldots . \quad \ldots \quad 35$

al. Alpina, Stgr. $\quad \ldots \quad$ ․

v'ur. Calida, Bellier .. $\quad \ldots .35$

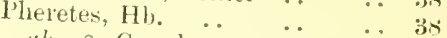

ab. \& Caruleopunctata, Wh.

(11. ab.) ‥ ․ . 35

al. Malogensis, liühl .. $\quad$.. $\quad 39$

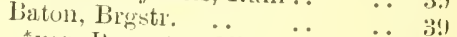

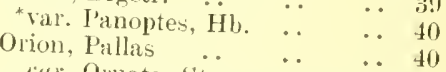

inr. Ormata, Stgr. $\quad \ldots \quad \ldots 40$

'ur. (and $a b$.$) Nigla, Gerhard 40$

Optilete, Knoch ... .. .. 11

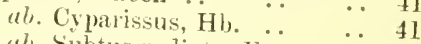

Rusticus, Hb- .. 11

(Kephyrus, Frivaldski)

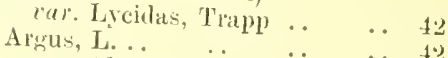

iar. Alpina, Berce $\quad \ldots \quad$.. 42

$\begin{array}{llll}\text { al. Bellit, H.-S. } & \cdots & \ldots & 43 \\ \text { irylognomon, Brorst. } & \cdots & & 43\end{array}$

"ar. Egidion, Meissner'

al). \& Alrulus bres

(1). \& Unicolou, Far

rior. (and $a b_{0}$ ) Spuler

Eyeres, Hb $\quad \cdots \quad \ldots . \quad \ldots \quad 14$

Argiales, P'allas. . . . . . . 44

al. Polysperchon, Brirstr. $\quad \ldots \quad 14$

Cyaniris, Dallu. Ochs. .. .. 44

Areriolus, L.

ab. Parvinunctata, Fuchs - 45

Lampides, $\mathrm{H}$ l.

Buticus, L.

Telicanus, Lamo $\cdots \quad \ldots \quad$.

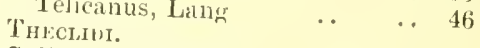

Callophrys, Billberg

Rubi, L. . .

ab. Immaculata Fuch $\quad$. 46

Læosopis, limbr.

* lioburis, Es

Zephyrus, Dalm. $\cdots \quad \ldots \quad \ldots 47$

Quercûs, L.

(t). Bella, Gerhird $\quad \ldots \quad \ldots 47$ 


Betule, L 1'stil: ab. s Sininosa, Gerhird $\quad \ldots 44$ (? ab. l'allicla, 'T'utt) $\quad \ldots \quad \ldots 47$ ab. \& Fisonii, Wh. (11. ab.) .. 47

Thecla, liabr.

11 -album, Knoch ab. Butlerowi, liroulikotiski.. tn

llicis, ksp. $\quad$. $\quad \ldots \quad \ldots 4$ rur. (and ab.) Cerri, Hb. ... 4 !! (1). Fiseuli, Hb. .. .. 4 .t

Spini, Schitf. . . $\quad \ldots \quad$..

I'runi, L. . $\quad \ldots \quad \ldots . \quad \ldots 50$

Acacile, Fabr, ... $\quad \ldots \quad \ldots 50$

\section{LEMIONIIDE.}

NEIIEOBHX.E.

Nemeobius, Stph.

Lucina, I. al. Obsoleta, Tut *ab. \& Lyuceus, Hb. .. $\quad$.. 50

pleild k.

Aroriloi.

Aporia, HIb.

Cratregi, I. .. . . . . . . (t). Sulfusa, 'I'utt .. .. 万s ab. Marginata, lutt .. . . jo ab. Lunulata, 'Tutt .. ... jos ab. Melaina, T'utt .. $\quad$.. 58 ab. \& Flava, T'utt .. . . ju

\section{línioi}

(ab. Alepicis, Cosmovici) ... ix

Pieris, Schrank

Brassicæ, L. . . . . . . . var. Chariclea, Stph. . . . j!

liapre, L. .. . . . . . . . .! al. Minor, Costa _. $\quad \ldots \quad 5 !$ var. Metra, Stpl. . . . . 5? $u b$. Leucotera, stefinelli .. j)! ab. Immaculata, Coekerell .. 5!) rar. Messanensis, Zll. . . 59 ab. Mannii, Mayer . . . . .,!

(? $a b$. \& Sovanglia, Scudder) .. 59

Napi, L. .. . . . . . . 5! var. Sabellica, Stpl... .. 150 ub. Napre, Esp. .. $\quad \ldots \quad 60$ var. \& Bryonize, Ochs. $\quad \ldots 60$ (i). Sulplutrea, Schöyen . 60

Pontia, Fabr.

Callidice, Espo. . . $\quad \ldots \quad \ldots \quad$ (it

Daplidce, L. $\quad \ldots \quad \ldots \quad \ldots \quad \ldots 1$ $v a r$. (and $a b$.$) Bellidice, Oclss. 6: 2$

Axтносн+1II.

Anthocharis, Bsdr.

Simplonia, Frr. . . . . $\quad \ldots \quad 6 \%$ ive. Flavidion, Wh. (11. var.) 62

Belia, Cramer .. $\quad \ldots \quad \ldots$ (j; var. Ausonia, Hb. .. . . 63

(Tagis, Hb.)

* var. Bellezina, Bsdr... .. 6 6i⿱

Thais, Fabr.

I'olyxena, Schitf. _... . . . . " iar. Cassandra, Hb, .. .. 5: *al. Meta, Meigen _. . . 53 (limina, L.)

* "ur. Medesicaste, Hliger" . . .53

* ab. Honoratii, Bsdr. . . . . j4

PARAASAIII.

Parnassius, Latr.

A pollo, H. ... j j ab. Carpathica, liebel $\quad$. 5.j al. Wiskotti, Obth. .. . . 55 (1). Novaræ, Obth. .. .. . j.) ab. Nevadensis, Obth. .. j.j var. I'seudonomion, Christ .. 5. 5 ab. \& Brittingeri, liebel .. .j.j

J)elins, Esy. ... . . . . jt; al). \& Herrichii, Ohth. ... 5it a). \& Cardinal, Obth. .. jt; ab. Inornata, Wh. (11. ab.) .. 56; al). Jeonhardi, liaihl .. 5lj ab. \& Hardwickii, liane .. Si (a). Aurantiaca, Spuler _. \$7 ab. \& Nigrescens, Wh. (n. ab.) 57

Mnemosyne, L. . . $\quad \ldots \quad \ldots 57$ al. \& Meluina, Honrath .. 57 ab. Nubilosi, Christoph $\quad \ldots \quad 57$
Euchloë, Hb.

Cardamines, $\mathrm{H}, \ldots . \quad \ldots \quad \ldots, 6,4$

ab. Lasthenia, Milliure ... bit

(ab). Turritis, Ochs. .. . . (i1

(4). Citronea, Wh. (11. ab.) .. 6f

Euphenoides, Stgr. _. . . 64

Ler'Tositil.

Leptosia, Hb.

Sinapis, L. . $\quad \ldots \quad \ldots \quad 65$

ear. Diniensis, tisdr... .. fi.j

ab. \& Erysimi, Brkh. … (6.)

ab. Lathyri, Hl,. .. . . fis

ab. Sartha, Riihl .. .. fi,

ab. Subgrisea, Stgr". . . . 6.5

ear. Eistiva, Stgr. . . . 66

lijonocerili.

Colias. Leach

1'hicomone, Esp. ... .. fit;

1'alæno, L. $\quad$.

var. (and ab.) Europomene, Ochs... $\ldots \ldots \ldots 67$

ab. Flavoladiatu, Wh. (n. ab.) dis al. (and rar.) Herrichi, Stgr.. fir ab. Catlischi, Caradja .. 6r
Duponcheli, Stgr. $\quad \ldots \quad \ldots 66$

Hyale, L. .. $\quad \ldots \quad \ldots \quad \ldots 6 \sigma^{\prime}$ 
lititi.

ah. q Inversit, Alphéraky .. 6r

ab. Apicata, Tutt . . . 6s

ab. Obsoletal, Tutt .. _.. (is

ab. Tinimaculata, Tutt $\ldots$ (i!)

ab. Pallicla, Tutt .. . . ti!

(ab. Tiridescens, Sloper, n. «b.) ti!

*Chrysotheme, lisw. . . . ti!

* Mymidone, lisp. . . . .

ab. \& Alba, Stgr. .. . . il

Edlusa, Fabr. .. $\quad \ldots \quad \ldots$ ti?

al. Obsoleta, 'Jutt .. $\quad$. 70

(a), Brumnea, 'lutt .. . . 70

(1). Helecina, Ubth. .. . . 70

(1). \& Helice, Hb. .. .. 70

al. \& Pallida, Tutt .. .. 70

Gonopteryx, Leach

Rihamni, L. . . . . . .

*ier. Farinosa, Stgr. .. .. 71

Cleopatra, L. . . . . . . 71

NYMPHALIDA.

NIMPHALIN.E.

Ariyninir.

Dryas, $\mathrm{Hb}$.

I'tuphia, L.

(ab) loumaculata, Bellier

laudol's, Sclitti.

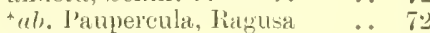

Argynnis, Fabl.

Aglaia, La.

(1). Nana, Wh. (11. ab.)

al. of Flavescens, Iut

al). \& Aurea, Tutt

ab. I Pallida, Tutt .

al. \& Sulfusa, 'Putt.

1i). Fusca, Tutt

Acliplpe, L.

ab. Virgati, 'T'utt .

(1). Internedia, 'Iutt .

frr. Cleodoxa, Uchis...

Niobe, I...

धr. kis, Meigen .. .. 7

ab. I'elopia, Brkh. .. .. 7 I

Issoria, $\mathrm{Hb}$.

Lithonia, L.

Brenthis, $\mathrm{Hb}$.

Euphrosyne, L. .. . . . . 7.

ab. Obsoleta, Tutt .. .. 75

Selene, Schiff. .. . . $\quad . .75$

al). Selenia, Frr. $\quad . \quad \ldots \quad 7 i$

(d). limaldus, Hust. .. .. Ti

al). Thalia, $\mathrm{Hb}$. .. . . 76

(? ab. Internedia, Spatugberg) .. Tr;

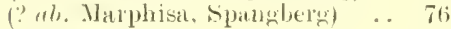

* Aphiratpe, Hb. .. .. .. Tti

He("ate, Esp. . . . . . . 76

Thure, Hb.

Daphne, Sichilt. . $\quad \ldots \quad \ldots \quad 77$

*ab. Conjuneta, 'Tutt .. . . 7x

Ino, Jiott...

iar. Kinalensis, liav... ... 7s

Anatlusia, Esp. $\quad \ldots \quad \ldots 78$

ab. Nigrofusciuta, Fav.
Dia, L. ..

Pales, Schift. $\quad \ldots \quad \ldots \quad \ldots \quad \ldots \quad 7 !$

var. Isis, Hb. .. . . . . si)

ab. \& Napar, Hb. .. .. so

ab. \& Cinctata, Far. .. . . 80

rar. Arsilache, Esp. .. . . $\quad 80$

Melitemin.

Melitæa, Fabr:

Cynthia, Hb. .. $\quad \ldots \quad$..

Maturna, L. . . . . . . .

var. Wollensbergeri, Frey .. $x 1$

Aurinia, liott. . . . . .. N2

ir. Merope, Prumner.. ... \$.

err. Artenis, Fabr. .. ... x3

rm. Signifer', Kane .. ... x.3

var. Ochrea, Tutt _. _. 43

var. Brunnea, 'lutt ... .. 83

rur. P'rovincialis, bsilv. ...

rar. 1berica, Obth. .. ... $\times 3$

i*ar. Orientalis, H.-S. ... \$.

ab. Virgata, Tutt .. ... 83

Plumbe, hinoch .. $\quad \ldots \quad \ldots \quad .83$

ab. Minur, Fies $\ldots \quad \ldots \quad 84$

iar. Occitanica, Stgr... .. \$4

ab. Etheria, Eversmann .. st

Cinxia, L... . . . . ..

(1). Suffusa, Tutt $\quad \ldots \quad \ldots$ s.j

ab. Olisoleta, l'utt .. . . \$ \$5

al. o Pallida, Tutt .. .. N.

* (*1). 1)inieusis, WVh. .. . .

*'Trivia, Schiff. .. .. .. . .j

?*var. Fascelis, Esp. . . . . $\times .5$

Didynia, Oclis. .. _. . . 85

var. Alpina, Stgl. .. .. . \$5

rar. Neridionalis, Stgr. .. 86

rar. Graca, Stgr. .. . . 86

"*r. Occidentalis, Stgr. ..

Deione, $\mathrm{Hb}$. $\quad \ldots . \quad \ldots \quad \ldots 86$

rur. Berisalensis, Far. .. si

Asteria, Frr. . . . . . .

Aurelia, Niclierl ... ...

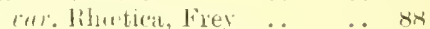

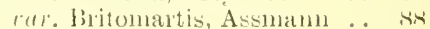

P'arthenie, Brkh... .. .. x!

¿(1). Virial, M.-D. .. ...

Athalia, Iiott. .. $\quad \ldots . \quad \ldots \quad \$ 0$

al. Navilina, Sélys-Longchanlps $\quad . \quad \ldots \quad \ldots$ !n

(1). Aphua, Hb. ․ . 90

(a). Catucasica, Stgr. . . . . 90

(1). Corythalia, Hb. . . . $\$$

al. Obsoleta, T'utt .. .. 91

al. Herthi, Quensel .. .. \$1

(ab. Tirgatio, l'utt .. ..

rar. Helvetica, Rithl . . . $\$ 1$

al). Lencippe, Schneider .. 41

Dictymna, Esp. . . . . .

Vixisinut.

Arachnia, 11 b.

Levana, 1. _ . $\quad$.. $\quad \ldots, 91$

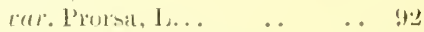

ab. Porima, Ochs. .. .. !2

Pyrameïs, $\mathrm{Hb}$.

Cardui, L... $\quad \ldots \quad \ldots \quad \ldots \quad \ldots$

al. Elymi, linbr. ․ . (12) 


(4). Luormata, liramson

Atrlantit, L. .. . . . . ab. Fructu, Tutt $\quad$. $\quad \ldots .93$ "h. Klenensiewic\%i, Schille.. ؛ !:

Euvanessa, sicurlder

Antiopu, L. ab. Lintueri, IFitch $\quad \ldots \quad \ldots \quad$ :1:3 ab. Hygiza, Heydenreich ..

Yanessa, Fabr.

Io, I

ab. Fixoculata, Nevmer (1). Belisarius, Obth. . (a). Fischeri, Ntandfuss) (rb. Cyanosticta, Raynol

Aglaìs, Hb.

I licie, L. ‥ al) T'urcica, Stom. it (1). Ichnusa, Bonelli .. ... !1 al. Ichnusoides, Scily-Longchamps (1). Atrebatensis, Bstr.

Eugonia, Hb.

I'olychtoros, L. .. $\quad$. . $\quad \ldots \quad$ !1! aib. Testudo, Hisp. .. . . !5

Xinthomelas, Esp. . . . . 95

Polygonia, Hb.

${ }^{*} 1_{4-\text {-album, }}$ Esp. . . . . $\quad \ldots \quad$ !.j

* Figea, Cramer $\quad \ldots \quad \ldots \quad \ldots \quad ! 5$

*val, . l-album, Esp. . . . . . .

C-alburı, L. $\quad \ldots \quad \ldots \quad \ldots g t ;$ al. (and var.) Hutchinsonii, liobson $\quad \ldots \quad$. $\quad \ldots \quad$ !) ab. Falbum, kis]). . . . !) (1). lieichenstettensis. Iiidıl . . !6 ab. Iotit-album, Newnlatm .. ! !f al. l'allidior, l'etagna .. !f; "b. Variegata, Tutt . . . 16

Nimlininir.

Limenitis, Fabr.

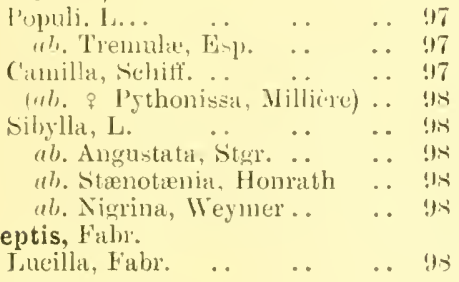

\section{APATURIDAE.}

CHalis.rin.

Charaxes, Ochs.

Itsius, I...

Apiti*IiIj.

Apatura, $\mid * a l n$.

llia, Schliti.

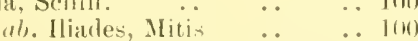
ear. (and ab.) Ctylie. Solniff... 101) ine. (and ab.) los, Rosisi .. 101) ab. Astasioüdes, Strl. . 100 (ab. Metis, I'rn... .. . . 100

llis, L. . . . . . . . . 100 ab. Iole, Schilt. $\quad \ldots \quad \ldots 101$
LIBYTHEID E.

P.Mil:

Libythea, lintr.

Celtis, Laclnating

101

\section{SATYRIDAE.}

SATYRIN.I:

P'Ararcilin.

\section{Pararge, Hil.}

Mrera, I.

(4). ()bsculd, 'lutt $\cdots$

al. Monotonia, Sichilide .. I0'2 ral. (and al.) Adrastat. Hb, . . 10\% ab. Triops, Fuchs . . . 102

Hiera, Fabr. . . . . . $10: 3$ ab. Trinoendata, Wh. (n. al).) 103

Megara, 1. . . . . . . 10:3 al). Alberti, liedlich .. . 104 (ab. Mediolugens, Fuchs) . 104 ab. Transcaspica, Stryx. . . 101 ab. Lyssal, Bsdy. .. .. J11

* Ėeria, I. $\quad$. $\quad$.. $\quad \ldots 101$ rar. Intermedia, Tutt.. ... I0.j ru. Ererides, Stgr. . . . 105 ab. Pallida, 'Tutt .. . . 10;

Achine, Scopoli .. . . . 105 Sitrinil.

Satyrus, Latr.

Hermione, 1. .. .. . . 16t; rar. Alcyone, Schilit. .. .. 10i;

Circe, Fabr, _. . . $\quad \ldots 107$

(*.) ub. Silenus, Stgr. . . .. 107

* Statilinus, Hufn... . . . . 107 rar. Allionia, Fabi. . . . . 10s

*Fiılia, L. .. . . . . 10 *al. Monticola, Thiervy-Mieg. . 10s

*Actara, Esp. .. . . .. 10x

Cordula, Fabr: . . $\quad \ldots \quad \ldots l$. 10 ! ab. \& lists, Hb. .. . . 1)! ab. Brice, Hb... ... .. 110

Enodia, Hb.

1)ryats, Scopoli .. . . . . 110 (1). Sibirica, Ster. .. . . 110

Hillislicinim.

Hipparchia, Fabi.

briseis, L. _. . . . 1111

ab. Major, Otth... _. . . 11]

*ab. l'irata, lisp. _. . 111

Semele, L. _ . $\quad \ldots . \quad \ldots 111$

(1). E Suftlsa, Tutt .. . 111

rar. Aristiens, Bonelli.. . . 111

ab. P'allida, 'Tutt .. . . 112

(1). 8 Ciecal, Tutt .. .. 112

ab. Addenda, 'lutt .. . . 112

Alethusa, E-p. .. . . . . 112 (1). Obsoleta, Wh. (11, ab.) .. 112 eut. Firythia, 11i, .. . 112 rar. livalulil, Iimbx. .. . . 112 car. Dentata, Stgrt. .. . . I12

\section{EPINEPHILIN EE.}

liprepHIIII.

Epinephile, $\mathrm{Hh}$.

Jurtilid, I.

al) 6 Suttusi, ']utt .. . . 11:

ab. ? Lallens, Thien'r-Mieg . . 11. 
ab. Semi-alba, Bruand

(1). Brigitti, Ljungl ..

var. Hispulla, Hb. . .

ab. \& Violacea, Wh. (n. ab.) . . 113

ab. Erymanthea, Esp. .. 11:

Lycaon, liott. .. .. . . 1 I3

Tithonus, L. .. $\quad \ldots \quad \ldots 111$

ah. Excessa, Tutt .. $\quad$.. 114

(1). Creca, Tutt.. _. . . 114

al. Mincki, Séebold .. .. 115

1 (da, Esp. .. . . . . . . 115

*'asiphaé, Espr. . . . . . . 115

*(ab. Flava, Wh. 11. ab.) _. 11j

Cis:xoximphit.

Aphantopus, Wallengren

Hyperanthus, L... . .

(i). Minor, Fuchs

. 115

ab. Creen, Fuch

ab. Obsoleta, Tutt .. ...116

al). Vidua, Miiller .. . . 11;

(a). Octoculata, Gï\%e .. . . 11;

ab. Lanceolata, Shipp . . 116

Cœnonympha, $\mathrm{Hi}$.

(Gdipus, Fabl. .. ... 116

Hero, L. .. $\quad \ldots \quad \ldots . \quad \ldots 116$

$\left(?^{*}\right)$ ab. Aretioüdes, Fologne .. 116

Iphis, Schilf. $\quad \ldots \quad \ldots \quad \ldots 117$

ab. Anaxagoras, Assinuss .. 117

ab. Carpathica, Hormuzaki . 117

Arcania, L. $\quad \ldots \quad \ldots \quad \ldots 117$

l* $)^{*}$. Iusubrica, Rätzer _. 118

var. Darwiniana, Stgr. . 118

ab. Philea, Fr'. .. .. 118

ab. Obscura, litihl .. .. 11s

ab. Obsoleta, Tutt ... .. 11s

Satyrion, Esp. . . . . . . 118

iar. Enicolor, Wh. (11. var.).. 119

al). Caect, Wh. (n. ab.) .. 119

Dortus, Eisp, _. . . . 116

I'amphilus, L. . . $\quad \ldots . \quad \ldots 113$

ab. Bjipapillata, Cosnovici .. 11!

al. Obsoletd, 'Intt .. . . 119

al). (and var.) Lyllus, Esp. .. 11!)

*ab. Iarginata, Iíubl .. .. 120

al. Inicolor, Iutt .. . $1: 0$

(1). Ocellata, Tutt ... .. 120

a). l'allida, Tutt .. $\quad \ldots 120$

Typhon, Rott. .. $\quad \ldots \quad \ldots 120$

¿ar. Philoxenus, isp. . . 120

rar. Laïdion, brkh. .. . 120

ab. Isis, Thunberg .. . 120

ab. Obsoleta, Tutt . . . 120

\section{EREBIIN E.}

\section{(J) NE11H}

Eneis, Hb.

Aëllo, Hl.

Erebia, Dalm.

*Epiphron, knoch _. . . 122

var. Valesiana, M.-D. $\quad \ldots 1 \%$

iar. Cassiope, Fabr. . . . 123

ver. (and ul.) Nelantus, Bsdv. 123

iar. Mnemon, Haworth . . 123

ab. Obsoleta, Tutt .. . . I23
Melampus, Fssl. ...

ab. Suretica, Stor.

ab. Randie, Fav. $\quad \ldots \quad \ldots 123$

Flavofasciata, Heyne . . . 12:3

* Arete, Fabr. $\quad$. $\quad \ldots \quad \ldots 124$ * (ul). o Albofasciata, Höfner.. 124

Eriphyle, Fr' (ab. Intermedia, Frey _. 12,j ab. Impunctata, Hoiner . 12.5

Phate, Hb. . . . . . 125 (a). Phartina, Stgr. . . . 125

* err. (and ab.) Fasciata, Śpuler 125

Christi, Rätzer .. . . . 126

Inestra, Hb. $\quad \ldots \quad \ldots \ldots 126$

Alecto, Hb. $\quad \ldots \quad \ldots . \quad \ldots 127$ ab. \& Perseplione, Esp. .. 127 cur. Glacialis, Esp. .. . . 12 ab. o Pluto, Esp. .. . . 128

Manto. Esp. . . . . . 12x rer. Pyrrhula, Fiey .. . . 129 al. Bubastis, Meissner _. 12!) ab. Crecilia, Hb. .. . 129

Ceto, Hb. . . .. cur. Obscura, Niatzer .. . . 130 ab. Caradjæ, Catlisch .. . . 130

*ub. Phoreys, Fin. .. ... 150

Nedusa, Fabr. $\quad . \quad \ldots \quad \ldots 130$ vur. Hipponedusa, Ochs. . . 130 a). \& Procopians, Ilomuzaki 1:31 cur. Psodea, Hb. .. . . 131

Eme, Hb. ... .. . . 131 rar. Lugens, Stgr. . . . . 131 iar. Spodia, Stgi. _. . . . 131

Stygne, Ochs. .. $\quad \ldots \quad \ldots 132$ ¿ar. Valesiaca, Elwes $\quad$.. 132 iar. Pyrenaica, Rühl . . . 132 al. \& Aboculata, Fav. .. 132

Evias, Godart . . . . . 133

* Nerine, Frr. . . . . . 133

* ear. Reichlini, H.-\$... .. 134 ear. Stelviana, Curo .. . . 13!

*(?)ear. Horula, Spr. . . . 134

* Seipio, Biclv. .. . . $\quad \ldots 131$

Euryale, Esp. . . $\quad$. $\quad \ldots 131$ ab. Ocellaris, Sterl. .. . . 135 ab. Enryaloides, 'l'engstrom 13.5 ab. \& Ochracea, Wh. (n. ab.) 13.) (4). Philomela, Esp. .. .. 13.5

Ligen, J. .. . . $\quad \ldots \quad$.. 135 var. Adyte, Hb. _. . . 136

Ethiops, Esp. . . . . . . 136 ab. Obsoleta, Tutt . . . . 136 ab. Inxqualis, Mousley _. 136; a). \& Nigra, Mousley _. 137 ab. p Pallida, Mousley .. 13i (1). \& Flavescens, Tutt . 137 ab. Stricta, Mousley .. . . 137 a). Leucotienia, Stgl. $\quad$. 137 ab. Ochracea, Tutt .. . . 137 ab. Violacea, Wh. (n. ab.) . 137

Neoriclats, Bsdr. .. . . . 137

l'ronoë, Esp. . . . . . . 13\% car. Jitho, Hb. .. .. 13s

Epistygne, Hb. .. ... „. 13 is

Goante, Esp. .. . . $\quad \ldots 139$ 




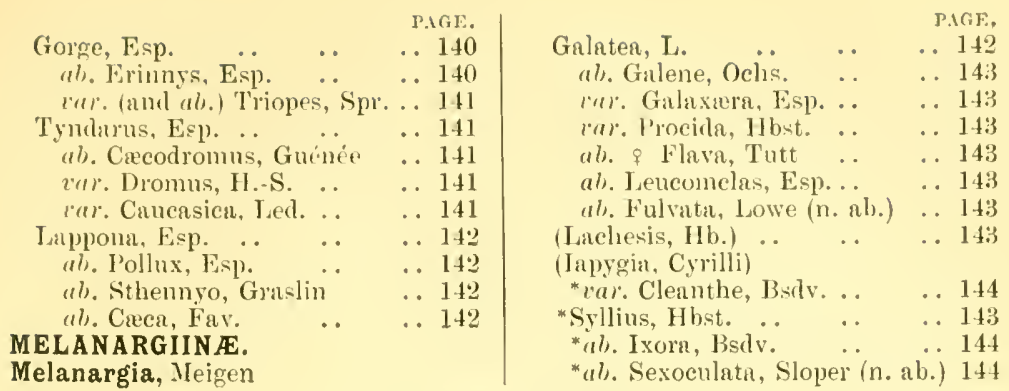

\section{GEOGRAPHICAL INDEX OF LOCALITIES.}

The following index does not profess in any way to replace "Baerlecker," which is essential, but will, it is hoped, serve two purposes; 1st that of giving a general idea of the geographical position of most of the localities mentioned under the different species, and 2ndly by means of the page references, that of a guide to the scarcer insects of a given locality, and to the insect or insects for which a locality (of otherwise merely ordinary interest) is worth a visit.

The following abbreviations are used: A. Mar., Alpes Maritimes (Fr. French ; It. Italian); R.A., Basses Alpes; B. Ob., Bernese Oberland; Car., Carinthia; H.A., Hantes Alpes; Pdm., Piedmont; Riv., Riviera (Fr. French, It. Italian); Sav., Savoie; Switz., Switzerland; Tyr., Tyrol (Aus., Austrian: It., Italian); also Ctn., Canton; Gl. Glacier: L., Lake; MIt., Mountain; P., Pass; R., River; V., Valley; and btwn., between; nr. near ; opp. opposite.

Aarau, Ctn. Aargau, X.W. Switz. 20 (bis)

Aarberg, Ctn. Berne, E. of Biemne 2u) (bis), 39, 50 (bis), 97, 105, $107,110,111,114$

Aar G1., above Grimsel P'.. J. Ob. 127

Abries, H. A., nr. 1talian frontier 2 (bis), s, 10, 12, 13, 14, 1.5, 16, $24,29,34,35,37,49,54,56$, (69. 61, 62, 66, $677,74,84,85$, $8 \mathrm{~s}, 106,109,111,114,117$, $132,135,137$

Arlelboden, B. Ob. .. . . .. 139 Aigle, Ctn. Vaud, Rhone V. 1, 6, s, $10,12,26,29,31,46,4 s, 49$ (bis), 50, 52, 64, 65, 70, 71, 72, $85,-49,97,98$ (bis), 100, 101, $103,104,105,106,107,109$, $110,113,114$ (bis), 117, 137 Aix-les-bains, Sinv. .. _. 100, 102 Alassio, It. Riv. $\quad . \quad \quad \ldots \quad 26, \quad 62$ Albula l', from Thusis to Samairlen, Grisons, 6, 39, 54, 5.), (11, (i6. 87, 129 Aletsch Gl., and forest, above Brig, to $\mathrm{N}$. of Rhone V. $15,22,67,140$ Allalin Gl., above Saastlual . 127 Allée Blanche, Val Ferret, S. side, Sizv.
Allos, B. A. $6,21,28,29,37,52$, $61,114,117,127,129,134,139$ Almagell, nr, head of Sasthal . 13:3 Alpe Pianascio, above Val Maggia, Ticino .. . . . . 12 Alpes de Lens, above Saxon, Rhone $\begin{array}{llllll}r & \ldots & \ldots & \ldots & 124,129\end{array}$ Alpe Tsehitta, WV of Albula P. . 12 Alp Grïn, Bernina P. . . . 141 Alpien, above simplon 1'.. S. Side 44 Alp Laret, nr. St. Moritz, Engadine \$2 Aniden, above the Walensee, to X., Ctn. St. Gall .. $\quad$. $\quad$. 75

Ampezzo Alps, 1t. T5r., N.F. of the Dolomites

Andematt, Ctn. Uri, St. (rotthard I'. 5, 6, 11, 14, 17, 56, 110 (bis) Amnéey, Savole .. .. 10. 111 Aunot, in S.1\% of B. A. 2:3, 47, 52, 1) 7,109

Anthemoz, on the Dent du Midi, above lihone $Y$. . $12 \%, 1$ l2

Anzeindaz, btwn. the Argentine and the 1)iablerets $\quad . \quad 37,131$

Aosta, Pdur., below Grand St. Ber nard $I^{\prime} .1,2,3,4,10,17,18$, $26,31,62,72,108,133$

Arbar, above sion, Rhone V .. 34 
Ardetz, Toper Engadine Ptor.

Argentine, At., between the Grand

Mieveran and the Diablerets 56 ,

Arlesheim, nr. Basle ... ..

Arolla, Val d' Hérens, abore Evo-

lena $14,17,28,33,3 \times, 39,57$,

(11, $62,166,67,74,82,121,125$, $127,132,134,140,141$

Arpilles, Mt., Martigny 4, .5, 10, 53. $67,121,126,129,140$

Arpitetta, Mt., above Zinal, Tal d'

Annivier's

Arve V., nr. Chamonix, Sav. 14, 103

Arzier, on the Vaudois Jura 1s, 45

Attalens, Ctn. Fribourg, above

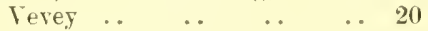

Au Pra, Pdm., high in Pellice V. 2,

$8,12,29,34,37,66,139,141$

Auribeau, Var, nr. Camnes 26 , 4i)

Axenstein, above Tirunner, Is. of Lucelne

Axenstrasse, road on F. bank of $\dot{\mathrm{L}}$. of Uri ..

Bad Alveneu, Albula P., N. side 10, $24,49,61,84,98,110$

Puden, nr. Vienna .. 107 (bis)

Baltschierler $\mathrm{V}$., to $\mathrm{N}$. of Rhone $\mathrm{V}$., opp. Visp $\quad \ldots \quad 11,42,57,133$

Bitcelonette, B. A., in the I baye Y. $12,16,25,29,29,37,49$, $50,(15,9 \times, 109,111,112,114$, $117,119,134,137$

Bürenfallenalp, Simplon P. 4.
Bisle, N.W. Switz. 2, 4 (bis), 7, 10 (bis), 21, 33 (bis), 39, 43, 45, 48 (bis), 49, 50 (bis), 5.5. (i2, $74,75, \times 3,85.89,92,97$ (lis), 106, 107, 110, 111 (bis), 114, 117 (bis). 130

Paveno, L. Maggiore, N.E. l'C.m. $2 \cdot 2,70,72$

Beaulieu. Fr. Riv. .. 22, ti, titi.

Вeauvézer, J, A. 4 (his), 21, 30, 37 , 52. 114, 127, 134, 139

Bechburg, N. Jura 4, 39, 75, 92, 47, 105, 106 (bis), 107, 111, 117 (his), 130

Beinette, S.W. I'dm., below Certosa di Pesio.. $\quad \ldots \quad 13,20,46$,

Belalp, to N. of Rhone V., opp. Brig … ․ 41, 67, 90, 127 Berchtesgaden, Burarian Highlands, S. of Sillzburg 15, !2. 10:5

Pergell, $r$. Val Bregaglia

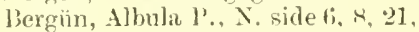
$34,77,78,68,91,98,132$

Périsal, Simplon P.. N. side 1, 3, .; (bis), $8,13,15,17,18,19,21$. $22,25,2 \times$ (bis), 2!) 31, 32, 33, $35,39,42,43,57,54,60,61$. $(j 2,75,76,84, k 5,88,90,10 \%$,

$106,112,11 \%, 133,137,1391.141$

Bernardine l'., from Hiuterrheinthal, (irisons, to Bellinzona, 'Ticino
Perne, Switz. 6, 10, 20 (hic), 48 $75,92,97,101,107,117,120$

Pernek. N.E. corner of Ctn. St. Gall 117 Bernex, Sav, on the Dent d'Oche, above 1. of Genera .. 114

Bernina Hospice, at top of Berninit P., from Pontresina to Tirano (Italy) 39, 61, 76, 81, 90, 140, 141

Berthemont, A. Mar. (Fr.) 12, 89, 130 Bex, Vand, Rhone V.17, 21, 52, 58,

$63,89,105,143$

Bienne, Ctn. Berne, at foot of Jura $3,21,50,105,111,113$

Binn, E. of upper Rhone V. 15, 22 Bisbinno, W. bank of L. Como 26 , $82,11 \%$

Blmenthal, above Mürren, B. Ob. 25 Bobbie, W. Pdm., in Pellice V. 1, 2 (bis), 12, 15, 16, 17, 29, 31, 34, $37,40,72,74,107,111,114$,

11\%, 134

matt $\quad$. 21

Bois de Ibâtie, nr. Geneva . . . 20 lois de Bay, nr. Geneva 21, 26,

48,105

Bonfol, N.W. corner of Switz. . . 116 lordighera, It. Riv. $\quad$. $\quad 46$ (bis) Joréon R., A. Mar. (Fr.) 60 (bis), 102,133

Bormio, Tal Tellina, It. Tyr. 4, 49, 134 Bortelalp, above Bérisal, Simplon

$$
\text { P. } \quad \cdots \quad \ldots \quad 4, .) \text { (bis), 14) }
$$

Bossey, m. Geneva 2.5, 45, 94, 111, $114,11 \%$

Botzen, W. Tyrol, $\mathrm{N}$. of the Dolomites $1,2,3,4,7,23,31,35$, 40,49 (3 times), $50,50,77,85$, $108,109,118,143$

Bourget, m. Chambérs, Sav. 74, 110,112

Bourg d'Aru, Isère, nr. Bourg d' Oisans 2, 13, 2(9), 35, 77, 106, $11 \kappa, 1: 3$

Jourgr d'Oisans, E. of department of lsire, France $1,2,12,17$, $29,35,77,98,106,109,110$, $114,13 \pi, 137,139$

Bonrg St Manrice, E. Sav. 1, 2 (bis), $8,12,17,18,29,35,4 !)$, (j2. $84,9 \times, 106,109,114$

Houveret. S.E. corner of $\mathrm{L}$. of Genevil 42, 4.5, 7.5, 7tj (bis), 7s, $\times 3, \quad 91$

Bovemier, mr. Martigns, ft of Gri. St. Bernard P...

Hovine, Mt., above Martigny 4, 5, li, $41,67,121,126,129,140$ lbzingen, at foot of Jura, nr. Bienne... … . .

Branson, Khone V.. opp. Martigny 2,5 (bis), 25, 2ti, 27, 31, 40, 43,44 (bis), 61, 70, 104

liremgarten, Ctn. Aargan, ‥ Switz. !T lipenner $\mathrm{F}$.. W. Tru.. $\mathrm{S}$. from Innthruck 2, 22, 3! (bis), 61, 


66, $67,77,20$, s., 121,128 P.(1): $12 ! 1,138,133,1+1$

Brivent, Mt., nr. Chamonix, Sav. $2,8,12,1.5,16,22,61,72,127$. $12(1,1: 2$

lirienzer Rothhorn, Mt., X. of I. of Brien\% .. ... $89,121,12 \mathrm{x}$ Brig, lihone V., ft. of the Simplon I'. 2, 3, 5, \&, 10, 1s, 19 (bjs). $25,26,34,39,39,4 \kappa, 49,62$, $8.2,105,109,11 \%, 11 \%, 133$

Hrunnen, Ctr. Sichwyz, on L. of Lucerne $11,49, \times 2,120,132$

Bmusio, S. of Poichiaro $\mathrm{r}$., $\mathbf{S}$. side of Bernina J'. 4, 10, 40, 5.5, 73, $101,109,11 \kappa, 12 ;$

biinschen, above Weissenburg, B. Oh. $\quad \cdots \quad 20,21,22,67$,

Bïren, Bernese Seeland, nr. T. of Bienıe.. .. .. . Burgilorf, Bernese Wittel!and 2, 4, $5,4 \times, 75,85,92,97,101,107,111$

Burgenstock, Mt., n. I. of Incerne !s

Cadenabbia, W. bank of $\mathbf{l}$. Como 111,116

Cagnes, S. of A. Yar. (Fr.). on the Loup .. . . . . Calanda, IIt., W. of Coire, Grisons

Campler, Cpper Engadine 4, 6, 13 , $2 x, 29,35,37,41,62,66 f .67$. (j), 7א, Ri (bis), 119, 121, 141

Campiglio, S.W. Tyr. 12, 1.; 16 , $21,22,2 \times, 56,61,66,76,78$, $42,44,109,111,121,127,130$. $138,140,141$

Cannes, Fr. Riv. 2, 3, 8, 27, 29, 40, $4 \times$ (bis), 5i), (52, (i5), 74, 95, y!), $101,11.5$

Castellare, in S.F. of B. A. 30, 39, $46, . ; 2,112,118$

Cassilate, E. of Lugano .. 44. 11 i Catome. Mt a above Mlartigns, to S.1. 197 Cilux, above Nontrenx, L. of Geneva 14, 14, 22, -2. 8:3, 117. $12 k, 131), 1: 3$

Celerina, T'pper Engarline.

Certosa di Pesio, S. WV, Piedmont ¿(bis), 4, 6, 13, 15, 16, 17, 1s, $20,23,26,29,30,35,37,40$, $44,46,48,49$ (3 times). 50, 57. 151,62 (bis), 133, 71, 77, 86, ! (1)is), 100 (bis), bol (his), 10:3. 107 (bis), 114, 122, 195, 12s. $129,1333,13.5,136,137,1394$ $140,141,142$

Chamossaile, At.. above Aigle .. Chamonix, Sinv. fort of Mt. Blane (6. 33), 3!), 41, 5(i, (i) $192,677,72$, 11i, 1:39

Champiry, in Val d'llliez, S. of lihone V., opp. Aigle.. 21, Chandolin, above Val d'Amniviers ;т, (i2, 71, 10:3, 12: 13:3

Chisrat, Rhone Y...
Charpigny, Rhone $\mathrm{V}$., between Ligle and Bex $26,47,50,52$. (ii), (i.), $82,84,10(1), 114,1$ If

('hasseral, .It., Jul', above I. of Bienne..

Chateau d' ()ex, Cm. Perme, V. of the sarine $\quad \ldots \quad \ldots \quad 77,144$

Châtenufort, 13.A. . . . . . . . 5:3

Châtillon, Yal d'Aostat. P'lm. ... I

Chavoire, nr. Annecy. Sar. 1, 10, $2 \cdot 2,2.5,44,4$ (b) (bis), 110

Chêne, nr. Geneva .. . . .. 2r

Chiasso, Tieino, S. point of Swit\%. $1 \times, 19,34,45,73,191,111$

Chiavenna, foot of Val Bregriglia, Lombarly

(1). 118

Chiêtre, btwn. Bex and st. Maurice. Phone $\mathrm{T}$.

Chillon, on N.F. bank of $\mathrm{T}$. of Geneva . .

Chippis, opp. Sierre, Rhone Y. .. I;

Cluinsa, helow Certosa di Pesio, Pdim. $\quad \cdots \quad \ldots \quad$ H, i07, $10 \times$

Choully, nr. Geneva _. . . 50

Churwalden, Grisons, S, of Coire $74,87,1: 3$

Cierfs, Munaterthal, S.E. (rrisoms 134 Cima Car, above Certosa di Jesio s!

Cogne Y., Pilm., IV. side of Yal il' Aosta 1, 8, 13, 15, 29, 2!, 37, 4!, $56,46,72,74,80,109,114,139$

Coire, X. Grisons '2, 13, 50, 177, 17 , $8 x, ! 1,57,101$

Col de Cheville; S. of the Diablerets,

Tiund

Col de Pillon, N. of Diablerets, Ctm. Berne - 131

Col de Pouaine, B. 1. ... ...

Col des Vaches, Kinal, Val d'An-

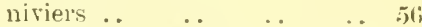

Col di Tenda, A. Mar.. It.. .51, 11א Col du Torrent, btwn. Evolena and Vissoye .. $\quad \ldots \quad \ldots \quad \quad .56,127$

Colmars, in E. of B. A. ... $\quad 37,127$ Coltura, Val Iireguglia, Grisons .. fi Comballaz, btwo. Sípey and Chatenu doex

Como, N. W of 1 . ombardy $2,34,10,4 !$ Comdanine, I3.A. .. .. . . if Corin, above Sierre, lihme r. 2:;, 50, (bis)

Come de Sorrebois. Val d Annivior 142 Cortina, X. Venetia, It. Trr. \&. 2:3,

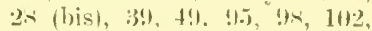
$1]$ (bis), 10.5, 1:31, 13:3, 1:35, $1: 3 \times, 140$

Commagem, l'lin., F. slopes of Jt. Blanc 1, s, 10,1:3, 16, 22.2. 2x (tiis), 24, 34, 3.5, 41, 14, 1!

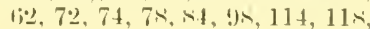
12:1, 13:3, 1:3!1

Cran, above Sit xon, lihone $\mathrm{V}$. .. sis Cresciano, Val Leventina, Ticimo.. 10! Crites de liegchisse, alove Abries, H. A. .. .. .. 1(i, $, 90,140$ 
Crevola, Pdm., S. side of Simplon P. $\quad \ldots \quad 40,52,99,101,118$

Cristallo, Mtn. in It. Tyzol .. 135 Croda di Lago, Mtn. in 1t. Tyr. 39, $133,135,136,138,140$ (bis)

Curfirsten, Mt., above N. of Walensee, Ctn. St. Gall _. . . 75

Daubensee, top of Gemmi P. . . 36 Davos, N. Grisons $4,11,14,18$ (bis), 67, 78, 80, 87, 127, 129, 133

Degershein, Ctn. St. Gall., _. 117

Dent de Corjeon, Ctn. Fribourg, nr. Château d'Oex

Dent de Morcles, Mt. Vaud, above Rhone V. . . . 103,127

Dent dn Midi, Rhone V. above St. Naurice 8: 125 (bis), 129 (bis), 131, 132

Devil's Bridge, St Gotthard., P btwn. Gïschenen and Andermatt .. 124

Diablerets, $\mathrm{I} t . \mathbf{N} . \mathrm{W}$. Valais 36,56 , $125,12 \mathrm{~s}$

Digne, centre of B.A. 1, 2 (bis), 4 13 times), 5, 7, 8, 10 (bis), 12, 16,17 (bis), 18, 21, 22 (bis), 23, $25,26,27,28,29,30$ (bis), 31, 33 (bis), 35, 37, 39, 44, 45 (bis), 46, 47, 49 (4 times), 50 (bis), $51,52,53,54$ (bis) $, 57,62,63$, $(64,65,66,70,71,76,77,79$, $82,83,84,85,815,95,98,100$, 101, 102, 107, 108, 109 (bis), 110,111 (bis), 11르 (bis), 114, 11s, 11!, 128, 132, 133, 134, $135,13 \%, 139,142,144$

Dischmathal, to S.E. of Davos 4, $11,25,28,67,76,81,12.5$ (bis) Disentis, in WV. of Grisons 10, 10

Divonne, Sav., btwn. L. of Geneva and Inra $\quad \ldots \quad \ldots 17,20$ (bis)

Dîle, Mt., S. Jura 21, 105. 11^, 13

Dolomites, Mts., S Tyrol .. . . 86

Domo d'Ossola, Hin., S. side of

Simplon P. . .
Dourbes, Mlt. nr. Digne. $8,61,111$ $128,134,139$

Draix, B.A. . . $\quad \ldots \quad \ldots \quad 134,139$

Drance V., btwn. Martigny and Orsières. $\quad . . \quad \ldots .5$,

Durand Gl., at head of Val de Bagnes, to S.E. of Martigny.

Eggen, Simplon P., S. side

Eiggenthal, 'Tyr., s.E. of Botzen $22,23,99,101$

Eggishom, to N. of Rhone T. abeve Fiesch ..

Egriswyl, nr. head of Emmenthal Einsiedeln, Ctn. Sichwyz 20, 40, $57,67,80,131$

Emmenthal, Bernese Mittelland, S.E. of Burchdort . . . Emsigenalp, S.E. part of Pilatus Engelberg, Ctn. Unterwalden, s. of L. of Lucerne 4,14, 15 (bis),

$17,33,41,43,57,67,74,77$, $89,122,128,129$ (bis), 132, 140 Engi, in Sernfthal, Ctn. Glarus125, 131 Engstlenalp. Ctn. Unterwalden,

S. IV. of Engelberg 4, 5 (bis), $6,57,121$

En Saumont, above Clarens, Mon-

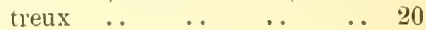
Entrevaux, in S.E. of B. A. $\quad 47,77$ Epplesheim, on Stelvio P. . 125 Esino, above Varenna, E. bank of L. of Como .. $\quad .17,32,133$ Esterel, Mt., W. of Cannes, Fr. Riv. $\quad \ldots \quad \ldots \quad \ldots \quad 45, \quad 54$ Evolena, Tal d'Hèrens, to S. of Phone V., opp. Sion 4, 16, 21, $22,29,33,34,36,48,56,67$, $90,127,129,133$

Faido, on S. side of St. Gotthard P. 45 Failleter, B. A. $\quad 37,39,60,139,140$ Falzarego P., s. Tyr. 49,61 , ti6, $80,13513 s, 140$ (bis)

Faulhorn, Mt., B. Ob., above Grindelwald $\quad . \quad \ldots \quad \ldots \quad \ldots 140$ Fenestrella, W. Pdn., S. of susa 11, \&1 Ferpicle, Val d'Hérens, above Evolena $\quad .16,58,66,75,127$ Fiesch, Ipper Phone V.15, 67, 72, $106,110,133,138$

Filzbach, above the S.W. of the Walencee $\quad . \quad \ldots \quad \ldots \quad 92,103$

Fina!marina, It. Riv. $\quad . \quad \ldots \quad$ (1.) Findelen, above Zermatt . . . 127 Flims, Grisons, W. of Coire 11, 77 Flimserstein, Mtt., N. of Flims 125 (bis) Fluela P., through the Fluelathal, from Davos to Siis, Grisons11, 125 (bic), 141), 141

Foliette, Mt., nr. Loìche-les-bains, Gemmi

Follaterre, Mt., Rhone V., opp. Verna faz and Martigny 3, 17 (bis), $22,31,33,42,45,61,70,105,113$

Forclaz, above Martiony on the P'. to Chamonix $11,22,57, \times 0$, $97,103,12.5,12 !), 133,139$

Franzenhöhe, Stelvio P., Aus. Tyr., $\mathrm{N}$. side .. $\quad . \quad \ldots i, 61,141$

Freniere, ahove Bex $\quad \begin{array}{lll}\text {. } & 21\end{array}$

Fully, N. side of Rhone V., N.E. of Jartigny $t, 5,4,11,15,17$, $23,40,44,51,72,8 \times, 89,98$ (bis), 117, 126, 12!, 110

Fnorcla di Surlej, S.E. of Surlej. Upper Engadine .. $\quad . \quad 58$

Furka, P. from N.E. Valais to Ctn. Uri $41,57,66,67,117,124,127,140$

Fusio, nr. head of Val Maggia, Ticino $1,10,14,1 \mathrm{~s}$ (bis), 21 , $22,28,33,39,40,61,66,82$, $124,126,127,129$ (his), 130,139

Gadmen, off Haslithal to E..3, 5, 21, 


$39,43,56,57$ (bis), $75,77,89$, $97,125,129$ (bis), 131

Gais, Ctn. Appenzell .. 120

Gumsen, Rhone V. between Visp and Brig $\quad . \quad \ldots \quad 44,133$

Gandria, on L. of Lugano, Ticino

Ganter, R., on the Simplon P., N. side $1,40,42,43,84$ (bis), 129

Gap, chief town of H.A. . . . 37

Gardone, on W. bank of $\mathrm{L}$. of

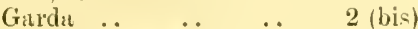

Gasterthal, off $N$. side of the Gemmi to E. . . . . . 125

Gemmi, P. from Spiez on L. of Thun, to Loèche, Rhone $V .5$, (j, 17, 41, 42, 5ij, 57, 60, 61, 121, 12.5 (bis), 131, 132, 134,

Geneva, S.W. Sivitz. 2, 4, 2.5, 26, 46 (bis), 49

Gias del Ortiga, above Certo $\sim a$ di Pesio.

Ginel, Jura Vandois, above Rolle $113,118,120$

Gimelwald, be!ow Mürren, B. Ob. 31,52

Giornico, Ticino, Val Leventina 12,109

Giubiasco, S. Ticino. below Bellinzona s. Ticino. be

Glacier de Miage, S. side of Mt. Blanc, l'dm. .. . . .

Glaisolas, B. A. ‥ $\because \ddot{\text {. }}$

Glion, above Unntreux $17,48,83$ (bis), 107, 117, 118, 131

Gorlessurt, B.A. $\quad 28,60,78,118,127$

Goldau, S. of L. of $\mathrm{Zug} \quad$. . 110, 111

Gomagoi, on the Stelvio, Austrian side.

Gondo, on the Simplon, S. side, Valais .. .. 10,17,64, 10:

Gorge de St. André, A. Mar. (1'r.) $40,65,144$

Gornergrat, ahove Zermatt 25, 36, $61,67,74,88,128,139,140,141$

Göschenen, Ctn. Cri, on the St. Gotthard P., N. side ..17, 41,

Gr.und Ferrex, at the head of the Val Ferrex, Valais .. 29, 141

Grand Ireveran, Mt., Vaud, above Bex. .. .. .. 127, 140

Grand St. Bermard, I'. from Martigny, lihone $\mathrm{V}$. to Aosta, Pdm. 17, 25, 41, 62, 67, 74, $121,129,1.11$

Granges, m*. Sierre, Rhone V. 15, $40,97,100$

Grangettes, farms nr. Filleneuve, at head of $\mathrm{L}$. of Geneva.. 17 ,

Grasse, A. Mar. (lir.), a bove Cannes $54,115,139$

Grengiols, Cpper Rhone $\mathrm{V}$, en trunce to Binnthal .. .. 98, 133

Grésy, above L. Bourget, Sav. 2, 8, 10 (bis), $17,22,33,44,46,49$ (bis), 51, 62, 70, 81, 98, 110, 111 (bis) 112 (bis), 114, 118

Grimsel, P. from Brienz to lihone

Gl. $5,15,41,68,121,124$, 12.), 142

Grindelwald, B. Ob., at head of Liitschinthal ...

Grödner Joch, S. Aus. 'Tyl', at head of Gridnerthal .. . . 134

Gros Glockner, MIt., E. Tyr. .. 6 is

Grusère, Ctn. Fribourg, in Sarine V. $\quad \ldots \quad \ldots \quad \ldots, \quad 33,103$ Gryon, above Bex, Rhone V. 6, 62, 73, 97

Guarda, Lower Engadine, entrance to Val Tuoi $10,14,21,22,23$, $28,24,33,37,39,41,56,666$, $67,77,78,82,84,87.111,126$, $127,129,140$ (bis)

Gumpoldskirchen, S. of Vienna .. 13 Gunten, on N. bank of L. of Thun 110 Gurgaletsch, Mt., S.L. of Coire 87, i:2 $), 130$

Gurnigel, Bernese Mittelland, nr. L. of Thun _. . 131,135 Guttamnen, in the Oberhaslithal .. 75 Gysulafluh, Mt., N.E. of Aarau .. 97

Hallwy̧l, htwn. Lucerne and Lenzburg (Aargar ) . . $\quad$. 129

Handères, above Evolena .. . . $3: 3$

Hasliberg, above the Haslithal, the N. side of the Grimsel 1'. .. 19

Hasli Scheideck, Mtn., S.W. of Haslithal

Handeek, in the Haslithal $14,77,125$

Heiligenblut, in N.W. comer of Car. 18, 34, 39, 60, 61, 66, 82, 121, 122, 1335 (his), 141 (bis), 142

Hérémence, off the libone V., opp. sion .. .. .. .. 133

Hermance, nv. Geneva, on $\mathrm{k}$. bank of L. $20,25,33,46,52,10.7,117$

Heuthal (Val det Fain), to N.E. of Bernina 1'., N. side 39, 57, 52, $57,90,140$

Hinterheinthal, Grisons, S.W. from Thusis .. $\quad . \quad \ldots$ 1.2.)

Hospenthal, on the Sit. Gotthard P. 22.

Hospitalet, 13. A. . . . . $\quad$. . 8:

Hottingen, nr. Zirich .. . . 45

Hutteggen (Huteeli), Saasthal 30,

Hiitten. S. of L. of Ziurich 4., 113 .. 111

Iffenthal, N. Jura, mr. Basle _. 10; Illgraben, S. of Iihone V., olpp. Loriclie . . . . . . (ii)

Inden, on s. side of (iemmi, below Jocke-les-bains 2., 2!, 36,51 , iT, 129

Innsbruck, in the Inn Y., N. Trr. $66,109,125$ (bis), 1요

Ins, btwn. Lakes of Lienne and Neuchâtel 
Interlaken, btwn. Lakes of Thuo and Brienz ... .. 33

Inelle, Simplon P., S. side, Pdm.2,

$16,71,9 ! 9,115$

Isonzothal, Tulian Alps, Carniola $40.77,163$

Jaman, Mt., above Montrenx 101

Jeur-Brûlće, above Branson, Rhone<smiles>[AlH2]</smiles>

$5,53,82,83$

Joch P., S. of Engelberg .. _. 129

Jorat, Mt., N. of Lausinne _. 20

Jura, Mts., IV. boundary of Switz. $4,5,7,10,12,14,17,21,22$, $24,25,26,28,29,33$ (bis), 34 , $43,48,49,50,52,55,60$ (bis). $66,74,78,82,83,85,89,918$, $100,101,106,111,112,113$, $117,132,137,138$

Justisthal, N. of L. of Thum \&, 19

Kalfenser (Calfeisen) Alps, Ctn. Glarts, S. of Ragatz . . . 12.5

Faltberg, in the Turtmannthal, $\mathrm{S}$. of thone $\mathrm{V}$.

Kandersteg, B. Ob., N. side of the Gemmi .. 28, 124, 125, 129, 131 Katzensee, Ctn. Zürich, N.IV. of L. . . . . 1 120

Kienthal, S. of Lake of Thum . 125 klönthal, in W. of Ctn. Glarus .. 98 Kor Alp, borders of Styria and Car. $22,25,37,41,117,125$ (bis)

Kupfernaseruns, above Filzbach, $\mathrm{S}$. of Walensee $92,10:$

La Bâtiaz, tower, E. of Martigny $15,30,62,86$ (bis), $87,89,10 \mathrm{~s}$ La Bocca, Cannes, Fr. Riv. 63, 107 La Bollène, A. Mar. (Fr.). .30, 52, $7{ }^{2}$ Lac de la Iadeleine, m. Larche, B. A. . $\quad$. $\quad \ldots \quad 4$,

La Clusaz, Sav., between Thônes and Megève, below the $\mathrm{Col}$ d' Aravis

La Faucille, Jura, Sav., N.E. of Geneva..

La Flégère, It., m. Chamonix, Sav.

Lagalp, E. of Bernina P., near top, N. side.

Lago di Garda, N.E. Lombardy ${ }^{\prime}$

Lago di Loppio, N.E. of Lago di Garda .. $\quad . \quad 31,44,110,132$ Lago Maggiore, Ticino and Pdm... 17 La Grave, Datphine, 13, 15, 35. $84,106,109,111,117,137$

Languard, R. and V., E. of Pontresina .. . . . 39,

Lanslebourg, at foot of Mt. Cenis, Frencl sich

Lat Pallette, above the Col de Pillon, B. $\mathrm{Ob}$.

Laquinthal, to S. of Simplon P., $\ddot{\mathrm{S}}$. side 21, 22, 24, 2.5, 62, 74, 89, $118,121,126,127,130,131,132$
Larche, X.E. of B. A., nr. Italian frontier $\delta, 10,13,15,16,18$, $29,37,39,41,49,56,60,61$, $62,66,67,74,82,84,85,88$, $153,109,114,117,132,134,135,137$

Lattrigen $\quad . .6 \quad \ldots \quad \ldots \quad 75,105$

Lausanne, on $\mathrm{N}$. bank of $\mathrm{L}$. of Geneva $8,17,45,50,72,75$, $98,106,117$

Lauterbrunnen, B. Ob., S. of Interlaken . $\quad . \quad 29,36,79,130$

Lauzon V., in Graian Alps, nr. Cogne 80

Lavancher', nr. Chamonix, Sav. .. 56

La Vare, above Bex, Rhone V. 28,

125,126

Lavey, Vaud, Rhone V., between Bex and St. Mamrice 24, 2.5, 26 (bis) , 27, 45, 62, 63, 77, 78,

Lecco, on S.E. of L. of Como, Lombardy .. .. .,

Le Coin, at N.W. of the Grand Salève, Sav. 8, 17, 25, 45, 103, 111

Le Litutaret, in Dauphiné Alps 2, $5,15,24,25,28,29,37,41$, $56,61,66,67,80,82,117$, 125, 127, 129, 130, 140, 141

Lenk, Simmenthal, 13. Ob. (misprinted Leuk) .. . . $\quad 20,120$

Lenzburg, Ctn. Aargau .. 92, 97

Le Penty, nr, the Glacier de Trient, above Martigny $\quad$. $\quad$. 132

Le Prese, S, side of Bernina P. Poschiavo V. .. . .83, 91, 97

Le Reculet, S.E, Jura, Sav., nr. Geneva .. .. 14, 21, 121, 1:1

Les Avants, above Montreux, L. of Geneva .. 17, 2(6, 29, 83,98, 114

Les Plans, above Bex, lihone V. 11, 119,138

Les Voirons, Mt., Say., E. of

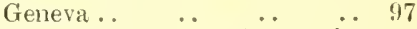

Levens, A. Mar. (Fr.) in the Yésubie Y. .. $\quad . . \quad \ldots 10$ s

Leysin, above Aigle, Rhone V. .. 48

Liestal, S.E. of Basle $4,7,10,20$, $2 \cdot 2,29,33,43,44,48$ (bis), $4 \%$, 50 (bis), 62, 89, $12,917,101$, $105,106,130$

Locamo, at head of L. Maggiore, Tieino 8, 17, 26, 39, 40, 64, $76,84,99,100,115,118$ Loèche (Leuk), Rhone V., btwn. Sierve and Visp '2 (bis), 30, 45, $49,62,72,77,117,118$

Loèche-les-bains(Lenkerbad), above Loèche, on S. side of Gemmi $4,5,8,14,17,29,36,60,61$, $62,74,76,89,103,109,127$, 128,129 (bis), 140

Lölling, on TV. slope of Sau Alp, E. Car. 2.5, 57, 77, 78, 117, 130 Losone, nr. Locarno, Ticino . 104 Lostorf, nr. Olten, N.E. Switz. 39, 113 Lütschenthal, N. of Rhone $V$., above Gampel. . 


fucens. Pinurl, above Lausame, towards Nenchated $\quad .75,92,105$

Luccrne, Central switz. 11, 17, 41,

$70,110,11.1$

Lugano, Tieino, at head of L. 2, 17, $40,45,52,111,84,99,101,106$, $108,1.13$

Lingern, Ctn. Interwalden, S. side of Brunig $\mathrm{P}$.

Lütschine, 2 lis., from Grindelwald and Lauterbrunnen $V_{s}$ s. to $I_{n}$. terlaken

Mucolin (Magglingen), Jura, above Bienne .. . . . .

Maengnaga, P'du., E. of Mte. liosa $10,15,18,21,28,114,129$, 130,131

Aruleramerthal, to F. of Amsteg, in Epper Reussthal .. .. 13

Madone des Fenêtres, Mt., A. Mar. (Fr.) $\quad \ldots \quad 18,22,56,61,71,133$

Magutimo, on N.E. of L. Matgriore 12

Malans, N.W. Grisons .. . 118

Malmoite, B. A. .. 37, 129, 134

Maloja, at top of $\mathrm{P}$. btwn. the Engadine and Italy $6,11,39$, (10, - 1, s. $4,103,121,125,127,13$.

Männlichen, MIt., btwn. Grindelwald and Wengen, B. Ob. 121, 129 (bis)

Jantegna, V., A. Mar. (Fr.), nr. Cinnes

Marcoux, nr. Digne, B. A... .. 20

Marly, nr. Hribourg, Switz. . . 48

Iartigny, Valais, Rhone V. 1, 2, 3,4 (bis), 5, 6, \$, 10, 12, 15, 16, 18, $2 \cdot 2$ (bis), $23,25,27,2 \times, 33$ (bis), $34,3-44$ (bis), 46, 44, 49, 50, $51,52,57,5 x, 59$ (bis), 60, 62 (bis), 63, 77, st, 85, 86, 88, 95, $100,104,105,106,10 \mathrm{~s}, 110$,

$113,117,118,192,133$

Mattmark, at liead of Saasthal 4 , 6,14 ,

Mayens de Sion, above Sion, to S. of Jihone $\mathrm{V} . \quad \ldots \quad 22,41,57,127$

Mayenwand, $N$. of the top of the Grimsel 1'. 11, 17, 68, 11\%, $122,124,127,140$

Megève, Sar., S.W. of Chamonix $10,22,74,139$

Meientlual, N.W. of Wasen on the St. Gotthard P.

Meiringen, in E. of B. Ob., entrance of Haslithal .. 20, 37, 75,

Mendel P., 'Tyr., S. of Botzen 2, 4, $8,18,45,49$ (bis), $50,60,61$, $70,74,77,80,84,98,101,103$,

$105,111,114,118,130,132,133$

Mendris:o, S. Ticino . 8 , !

Meratn, W. Tyr., N. W' of botzen 16, 100

Meyrin, nu. Geneva, Switz. 4, 22, $39,45,50,98,114$

Modane, S.E. corner of Savoie, nr. entrance of Mt. Cenis tunnel
Modling, s. of Vienna 2:3, 34, 40, 19, 69!) !99, 10:3, 107, 111

Moléson, Mt., liribourg, nbove Bulle

19,117

Mollis, Ctn. (ilarus, m. 1. of

Walenstadt (Wralensee) ..

Monnetier, Sitv., btwn. the Grand and l'etit Salive $5,6,8,1 \mathrm{t}$, 2.), $26,29,33,45,49,10: 3,111$

Montaigne de st. Vincent, Digne, B. A. . . . . . $\quad$.. 1 13!

Montana, above Sierre, Rhone $l$. $3,1,31,33,57,117$

Mont Bahe de la Frima, A. Mar. (Fr.) $1 \times, 29,49,111,62,117$, 121,130

IIt. Barry, Fribourg, m. Gruyère $2,8,11,11,20$ (bis), 33, 78, 82 ,

$117,120,131$

IIt. Buet, Sav., mr. Chamonix .. 141

Mt. Cenis, S.E. of Sav. $23,26,56,13 \times$

Mt. Chemin, Martigny to left of St. Belnatd P. 15, 17, 34, 79, s', $89,92, \quad 98$

Mt. Chétif, above Courmayeur, Pdm. . . . . .

IIt. Crammont, P'dm., above Conrmayeur... $\quad . \quad 84,85,88, \quad 90$

IIt. Cray, above Château d'Oex . 142

Mt. d'Autan, Martigny, Rhone V. I2I

IIt. de la Saxe, above Courmayeur, Pdm. . 66, 67, 80, 88, 141 (bis)

IIt. de Sion, Sas., S. of Genera 45, 106

Mt. d' Or', Jura, Fr' frontier', abore Vallorbe

Monte Bré, S. Tieino, on N. of L. of Lugano $(63,64,71,88,99,100$

Mte. Cenere, Ticino,to E. of head of L. Maggiore

Itte. Costa Rossa, above Certosa di F'esio ..

Nte. Faschia, above Certosa di l'esio (i) $1: 28$

Ite. Generoso, S.E. Ticino 45, 47, 1333

Ite. Grigna, above Lecco, Lom-

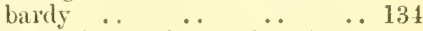

IIte. Matajur, Julian Alps (S.E. group, Carmiola) $\quad$. $\quad \ldots \quad 40$

IIte. Sulvatore, S. of Lugano 49,76

Mte. Viso, $\mathrm{P} d \mathrm{~m}$, , on frontier of $\mathbf{H}$. and B.A. .. .. .. 23

It. Pélérin, above Vevey, Vaud, L. $\begin{array}{lllll}\text { of Geneva } & \text {. } & \ldots & \ldots & 107\end{array}$

Mt. Ravoire, ubove Martigny, liholie I. .. . . \&, 23, 111, 129

Montrenx, Vitud, E end of L, of Genera... . . 20 26, 71, 106, 107

Mt. Suchet, Swiss Jura, above Vallorbe $\ldots \quad \ldots 661,66$

IIt. Vinaigrier, Fr. liv. Wr. of Cannes.. $\quad . \quad$. 633, 65, 83

Nörel, Tpper Rhone V. $1,26,67,133$

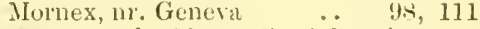

Morteratsch Gl., to S. of Bernina P., S. side $\quad .1,21,41.67,68$ 
Mondon, Vaud, btwn. L. of Geneva and L. of Neuchatel .. ..

Miihlebachalp, Ctn. Glarus 125, 131

Mïhlen (Molins), Julier 1'., btwn. Tiefenkasten and the Engadine 116

Miinsterthal, E. Grisons .. . . 20

Muottas, Mt., nr. Pontresina . 77

Miirren, B. Ob., above Lauterbrunnen $14,22,24,29,31,39(3)$ times), 41 (bis), $60,66,125$, 129,131 (bis), 132, 1:35, 137, $135,139,141$

Mythen, Mt., Ctn. Schwyz 57, 13:

Nairs, Mt., above C.mmpfer, Cpper Engadine

Naters, nr. Brig, Rilone Y. 14, 8j, 89,111

Nax, on Mt. opp. Sion, lihone Y.

Neuchatel, IV. Switz., on the Jura $62.106,114$

Neulatusen, at the Schaffhausen Falls

Neuveville, Jura, on W. of L. of Bienne 1, 20, 25, 45, 50, 10.5, $110,113,117$

Nice, lix. likis. $\$, 40,46,48$ (bis), $49,65,83,99,115$

Nicholathal, V., above Visp. .. (i)

Niesen, Mt., S. of L. of Thun .. 124

Niouc, above Chippis, entrance of Tal d' Anniviers 8, 16, 1!), 50, $57,62,72,74,77,81,103,133$ Nois, W. of Sierre, lihone T. 50 (l,is) Novallo (Nuovalo), n1. Cortina,

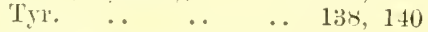

Oheramrgat N. part of Ctn. Berne 92

Oberalp 1'. to N.L'. of Andermatt $14,17,39,56,61,66,67,128,139$

Obergesteln, ¿plyer lihone V. . 125

Obergumigel, above Gumigel 19, 112,125

Oberhaslithal, upper part of Haslithal, forming $\mathrm{N}$. side of Grimisel 1'. ․ 8, 75, 77, 8!, 103

Oberstalden, btwn., Solnwytz and Glarus.

Oberutzwyl, in $\mathrm{W} \dot{\mathrm{T}}$. of $\ddot{\mathrm{C}}$ tn. $\dot{\mathrm{S}} \mathrm{t}$. Gall .. .. $\quad \ldots \quad 106,117$

Oensingen, Ctn. Soleure .. . . 97

Oftringen, in the Aarthal ..20, 50, 77

Olgiate, Lombardy, S.IV. of Conio $2,34,41,51,84,86,100$

Ollon, Vaud, Rhone V. .. .. 34

Olten, Ctn. Soleure $\quad \ldots \quad 3,21$

Onex, nr. Geneva, Switz. 1s, 44, $48,95,105$

Orbe, in the Jura Vaudois _.. 50

Ormont, above Aigle, Vaud 2, 17, 129

Orsières, in the Drance $T$., above Martigny

Orta, N.E. P'dn. $\quad \cdots 1,2, \ddot{4}, 26,33$ (bis), 40, 53, 10!), 118

Osterwitz, II. Styria on the Stainz Alps
Ozglosse, B.A.

P.tili.

Pain de Sucre, IV. of the Grand St. Bernard P.

Pantenbriicke, S. of Linthal, on the Sandalp

Parpinn, btwn. Coire and Tiefenkasten..$\quad \ldots \quad$. $\quad 5 \quad 56$,

Pas de Cheville, S. of the Diablerets Passo Babane, above Certosa di P'esio $\quad . \quad$. . $\quad$.. $\quad .$. Payerne, btwn. Fribourg and L. of Nenchâtel $\quad \ldots \quad \ldots c \quad \ldots \quad 92$

Pejo, Wr. Aus. Tyr. 11, 17, 222, 77, $81,82,105,121,127,130,132$

Pepiori, Mt., A. Mar. (Fr.)

Petit St. Bernard P., to E. of Grand St. Bernard $29,56,84,111$, 127,132

Pfäffer's, nr. Ragatz, E. of Ctn. Glartus .. $\quad \ldots \quad \ldots \quad 77,117$ l'fyn, village in the middle of the Pfymald $30,44,52,7 \pm$, 18

(bis), 100

Pfynwald, btwn. Sierre and LoècheSouste, on left bank of lihone $9,15,30,34,44,49,72,84$, $85,86,89,92,110,133$

l'ie de l'Aigle, A. Mar. (F'.) .. (j P'iexre-i-voir, Mt., above Saxon, Rhone $\mathrm{Y} . \quad 24,36,37,39,74$, $122,126,141$

l'ilatus, Mt.. IV. of L. of Lucerne $2,19,38,48,61,121,125,12 x$, $129,132,135$

Pinchat, nr. Genera $\ldots .44,46$ Piz Languard, Mt., to E. of I'ontresina $\ldots \quad \ldots \quad \ldots \quad 127,141$

Piz Okel, Mit., S. of Coire .. .. \&

l'an Cerisier, above Martigny Bourg, lihone V. 10, 30, 40, 87

l'ointe de la Lauze, above Abries, H.A. .. 140

I'onchette, $\ddot{i a l}$ d'Amiriens $28,7 \ddot{7}$, 108,128

l'ontarlier, central Fr. Jura $28,67,131$

Pont de Nant, above Bex $2,5,6,9$, $17,36,38,56,57,62,78,82$, $117,118,131,132,138$

Pontresina, Upter Ingadine 5(bis), $10,14,20,21,22,25$ (bis), 29, $35,37,39$ (bis), $41,43,56,61$, $616,67,74,77,78,80,82,84$, $85,87,18,118,121,127,139$, 140,141

l'oschiavo, S.E. Grisons, S. side of Beruina $\mathrm{P}$. . .. ..

Postalp, above village of Bienter, Tyr. .. $\quad 39,61,88,121,128$

Prätigau, V. of the Landquart, N.E. Grisons .. $\quad 56,101,123$ Prêles (l'rägrelz), Jura, mr. I. of Bienne .. .. .. .. 117

Pré St. Didier, Val d' Aosta, l'dm. 2 (bis), $4,12,13,16,17,29,31$, 


$34,35,40,41,4 ! 1,62,167,72$ (bis), 73, 77, 78 (bis), 84, 88, $98,109,111,114,118,135$ Promontogno, Val Blegaglia, Grisons

P'runieres, B. A.

Risgatz, E. of Ctn. Glaus 77, 92, 120 liandi, below Kermatt .. . . 123 liaron, lihone $\mathrm{V} . \quad \ldots \quad \ldots .51,52$ Reichenbach, above Spiez, I. of Thum ... .. .. ..

Rési, nr. Solemre . . . .

Reussthal, N. side of St. Gotthard $I^{\prime}$ 77 reulaz, above Vouvry, lihone $\mathrm{I}$.

$$
\text { . . . . . . . }
$$

Rheinthal, in E. of Ctr. Grisons 2, 101

Riffelalp, above Zermatt 3, 4,5, 13, $21,28,36,37,34,41,58,60$, 1) $1,62,80,42,90,127,128,129$

liveri, Mt., N. of Lneerne .. 2 29,103

livia, at head of $\mathrm{L}$. of Galda 31,133

liochers de Naye, above Montreux $19,41 j, 56,60,101,103,121$,

$13 \mathrm{~S}, 142$

liochers des Vents, alove Gryon, Vaud, $\mathrm{N}$. of lihone $\mathrm{V}$.

.. 111

Roja, li., A. Mar. (1t.) .. $\quad$.. 53

Roquebilière, A. Mar. (Fr.) _. 72

Rorshach, on S.W. of L. Constance 117

Rosegg G1, head of liosegg V., S. TV.

of I'ontresina 5 (bis), 25,28 , $41,57,77,81,127,140,141$

Iísenlaui, between Meiringen and Grindelwald, B. Ob. .. $75, \quad 77$

liossboden $\mathrm{Gl}$. and Alp, above Simplon P., S. side 90, 125, 140

liossinieres, in Sarine $\mathrm{V}$. $\mathrm{nr}$. Château d'Oex $8,21,33,77$,

47, 131,142

Rothenbach, S.E. of Emmenthal, Ctn. Berne .. ... Rouremont, in Sarine "Y. $\mathrm{nr}$. Chàteau d'Oex ... ..

Roveredo, at entrance of $\ddot{M}$ isox $\dot{V}$. Grisons.

Satanen (Gesseney), Ctn. Berne, $\mathrm{V}$. of the Sarine.

Saas, to $\mathrm{S}$. of lihone $\mathrm{T}$. above Visp $4,5,9,13,14,16,17,18,28$ (bis), 36, 38, 39, 41, 57, 62, 69 , 81 (bis), 113, 127, 132, 140

Sagno, 1r. Chiasso, Tieino 17, 76 Saillon, Rhone $\mathrm{V}$. opp. Saxon 3, 17, $25,26,27,48,63,77,87,104$,

Saint André, E. of B.A., N. of Castellane $\quad \ldots \quad \ldots 52,71,95$

St. Anton, S.E. Car. 125 (bis), 128

St. Beutenberg, above $\mathrm{N}$. bank of L. of 'Thun . . $\quad \ldots \quad \ldots 107$

St. Blaise, Neuchâtel Juia I, 3, 10,
I'AG1:-

$21,50,98,110$

St. Cergues, Vaudois Jura 7, 1., $21,22,48,7 \varsigma, 97,98,106,10 \%$,

St. Gall, N.E. Switz. 7, 10 (bis), $21,29,33,43,48,62,110$,

111,113

St. Georges, Vaudois Jura 5, 7, 14, $24,34,78,89,103,117,130$

St. Léonari, lihone $V$, btwn. Sion and Sierre $\quad . \quad \ldots \quad \$ 7,100$

St. Martin Vésubie, A. Mar. (Fro) $1,4,10,15,11,17,22,23,21 ;$ (bis), 30, 33, 34, 35, 45, 46, 47, 4!), 50 (bis), 52, 60 (bis), 61 , fi2, (bis), 6i3, (j.5, 6i6, 67, 7ะ, 73, 77, $81,83,84,86,89,95,100,102$, $107,108,109,110,117,118$, $121,127,129,130,133,135$, $136,140,141$

St. Maurice, n1. Cinnnes .. .. 46

St. Michel-de-Maurienne, in S. of Sav. $2,8,12,13,19,30,31$. $40,78,106,109,111,114$

St. Moritz, Upper Engadine 5, $20,28,24,67,74,76,80,133$

St. Nicholas, above Visp, 1, s, 16, $22,2 x, 29,39,42,74,84,86$,

$113,12 \%, 139$

St. Paul, Lavanthal, E. Car. 4!, fi?

St. Rény, nr. top of Grand St. Bernard 1'., S. side, Pdm. 72, 121

St. Sauveur, in $\mathbf{N}$. of A. Mar. (Fr.)

$7 \%$, $7 \cdot 2, \quad 77$

St. Triphon, Vaud, Rhone V., btwn. Aigle and Bex 1.7, 2.5,

36,45,

Salève, Mt., Sav., nx. Geneva 4, 14, $16, \quad 20$

Sulzburg, $\mathbf{N}$. of Province of Salzburg, Austria $15,6 \%, 76,81$, $10: 3,121$

Silquenen, (Silgetsch) lihone V., N. side, btwn. Sierre and Locche $4,23,30,34,89,104$

Salvan, above Vernayaz, Rhone $\mathrm{l}$. $57, \quad$ i1

Samaden, Ipper Engadine 28,129

San Bartolomeo, no. Certosa di Pesio .. .. .. .. 100

San Dalmazzo di Tenda, below Certosa di l'esio ... 46 (bis)

San Martino, Tieino .. . . San Stefano, nr. Chiasso, S. Ticino $8,22,26,40,73,76,106,110$

Sarnthal, N. of Botzen, Tyr. 23, $77,97,101$

Sassenage, Dauphiné Alps $\quad \ldots 137$

Sau Alpe, L. Cir. . . 22, 25, 124, 125 Saut du Doubs, Bernese Jur'a . . 1 Sauverny, nr. Divonne, S. Jura Sir.

Schafberg, Mt., above Pontresina

18,28 (bis), $39,61,119,124,129$

Schatfhausen, N. Switz. 7, 21, 2.5, 
$29,49,50,62,83,105,106$,

$113,117,120$

Schäfler, Mt., Ctn. Appenzell .. 121

Scluafmatt, Mt., above Aarau $3, \quad 7$

Scheideck, Mt., B. Ob., above

Grindelwald .. $\quad \ldots \quad 36,12.5$

Schinberg, Mt., Ctn. Aargau .. 129

Schönbrionn, S.IV. of Vienna .. y9

Schüpfen, Bernese Seeland 20 (bis), $50,92,97$ (bis) $, 107,114,120$

Schwal'zbach, on the Gemmi I'... o Schwarzsee, above Zermatt .54, 80

Sedrun, S.IV. of Disentis, on Oberalp P. .. _. . 13

Seealpthal, S. of Appenzell $\quad \ldots 77$

Sefinenthal, to W. of I pper Lauterbrummen V., B. Ob. .. $\quad 6 \% 2,12$

Seisseralp, S.-Aus. Tyr., S. of Grödnerthal .. ... ..

Sembrancher, Grand St. Bermated P., N. side $\because 3$, 3 , Sépey, Vaud, above Aigle, Rhone $\mathrm{V}$. $1,2,6,10$ (his), 11, 22, 2s, 29), $33,45,4 \times$ (his), 4!) 5!, (66, 8.5, $97,98,101,105,106,107,109$

Sertigthal, to S.L. of Dayos 45,56 ,

$57,1 \cdot 25$

Seyne, B.A. . $\quad$. $\quad 129,134,139$

Sierne, nr. Geneva.. 29, 45, 98, 110

Sierre (Siders), lihone $\mathrm{V} . \quad 3,4,5$

(bis), 8, 9, 11, 15, 17, 19, 22,

23,25 (bis), 27, 28, 29, 30, 38

(bis), 39, 40, 42, 44, 46, 48 (bis),

19 (bis), 50 (bis), 51, 59, 60,

$61,63,70,71,77,84,85, \times 6$, 85,89 (bis), 97, 98, 104, 10s, 113, 117

Sihthal, parallel with W. bank of L. of Ziurich $\quad \ldots \quad \ldots \quad \ldots 13$

Silser See, L. at Sils _. 22, 39, 81 Sils Maria, Tpper Engadin 28, 81 Simplon P., from Brig, Rhone. T., to Domo d'Ossola, Pdm. 3, :4, $14,16,21,24,25,35,36,39$ (bis), 40, 41 (3) times), 54. 5.5, 56 (3 times), 57 (bis), 61, 62, 66, 6i7, 68 (his), 72, 80 (bis), $81,82,84,8 \%, 106,109,11 \kappa$, $121,122,125,126,128,132$, $135,138,140$ (bis), 142, 144

Simplon Village, on $\mathrm{S}$. side of Simplon $\mathrm{S}^{\prime} \cdot \mathrm{s}, 10,14,16,17$, $24,28,33,36,39,61,101,125$, $127,130,139$

Sion (Sitten), lihome V. 2, 3, 4, 6, $8,17,19,23,25,26,27$ (bis), $40,45,48$ (bis), $60,62,63,77$, $86,88,89,94,100,117,118,13:$

Siselen, m. I. of Bienne .. .. 20 Soleure, N.W. Switz. .. 21, 39, 75 Sondrio, Val Tellina, Lombardy 44 , 76,101

Sonzier, above Montreux .. .. . 2 Siontuiss, s.' Ty'. .. 133, 136, 138 Sorvilier, Bemese Jura . . . . 98 Splugen P., from Hinterrheinthal,
Grisons, to Chiavemna, Italy $11,22,26,120$

Spondinig, on Stelvio P., E. side $107,108,111$

Stalden, above Visp, Rhone V. 1, 4, $8,17,19,21,30,42,49,61,62$, $64,72,74$

Stalla (Bivio), Grisons, at junction of Septimer and Julier Lasses

inenthal, and Steinenalp, above Bérisal 21 (bis), 36, 37, 57, 61, $66,177,65,70,74,121,127,138$

Stelrio P., Tyr., from Bormio (lt.) to Melan (Aus.) (f (bis), 2s, 34, $39,52,56,61,102,125,127$ (bis), 130, 134, 13k, 139, 141

Stelzing, N.W. Car. 124, 125, 130 (lois), 142

Stockhornthal, off the Simmenthal, N.E. of Weissenburg .

Stresa, on IV. bank of L. Maggiole $16,17,4 \%$

Strona V., nr. Orta, N.E. P'lnu... Stulzer-Weg, nr. Bergiin, on the Albula P.

Sulden, Wr. Aus. Tyr., under the Ortler .. . . . .

Surenenthal, above Engelber. 5, 57, $77,125,131$

Susa, P'dm., nr. foot of Mt. Cenis 2 (bis), 3, 4, 8, 11, 18 (bis), 19 , $20,26,28,31,34,35,44,46$, $49,50,54,57,62,63,65,79$, $84,88,95,98,99,109,101$, 108, 109 (bis), 111, 112 (bis), $118,129,130,132,137$ (bis)

Susillon, Val d'Anniviers 16, 74, 103,133

Susten (Souste), Rhone V., at E. end of the Ifynwald .. ..

Tamnenilp, Ctr. Unterwalden, E. of the linunig $\mathrm{P}$. . . . .

'Tarasp, Lower Engadine :3, 10, 2:3, $26,30,47,49,77,117,129,130$

Täsch, below Zermatt $\quad . \quad 5,62$

T'aulanne V., A. Mar. (Fr.) _. 136

Tavanasa, Rhine $V$., E. of Disentis 92

Thalalp, Ctn. Glarus, S. of Filzbach $\ldots \quad \ldots \quad \ldots \quad 92,103$

Thorenc, high in A. Mar. (Fr.) 4, $77,89,101,109$ (bis), 118, 136, 139

Thusis, Grisons, $W^{\top}$. end of Albula 1'. $\quad 16,33,43,72,110,132,139$

Thyon, above Vex, opp. Sion, Hhone Y. $\quad \ldots \quad \ldots .2,36,141$

Tiefenkasten, Grisons, on IV. side of Albula $\mathrm{P}$. . . . . 97, 133

Tinière Y., behind Villenenve, Vaud $19, \quad 97$

Toblach, Tyr, entrance to Dolomites

'Toggenburg, the IV. part of the Ctn. 135, i:s St. Gall.. .. .. . 110

Tolmein, in Isonzcthal, Carniola 1:3 


Torre Pellice, in Val Pellice, WT. P'lm. உ (bis), 17, 18, 19, 21, $34,35,39,40,54,62,72,73$, $76,81,99$

Toun d' Ai, Mt.. above Aigle .. 128

Tour de Gourze, above Cully, L. of Geneva. . . .. . Trafoi, on Stelvio P., Aus. side 6, $16,18,26,28,60,76,77,90$, $129,132,136,139$

Tramelan, Bernese Jura 19, 31, 50, $60,67,78,80$

Tre Croce, Cortina, It. Tyr. 78,125

Trient, above Martigny, $\mathrm{nr}$. $\mathrm{Fr}$. Frontier, towards Chamonix $11,22,24,36,57,62,121,125$, $126,129,130,131,140$

Triftalp, Mt., E. of Saas V. 5 (bis), 21

Trins, btwn. Coire and Flims, Grisons

Troinex, nr, Geneva $\quad \ldots \quad \ldots 26$

'Trois 'Torrents, Val d' Illiez, off lihone $\mathrm{Y}$., opp. Aigle.. ..

Triibseealp, S. of Engelberg 60, 124, 125 (bis), 131

Trümletenthal, B. Ob., from Laıterbrunnen V., to Eiger Gl. . 131

Tscherva Gl., at head of Iiosseg V, Engadine

Turtmannthal, off Rihone $\mathrm{V}$., to $\mathrm{S}$. $11,22,28,78,88,105,121,129$

Twannberg, Mt., Jura, nr. L. of Bienne .. .. .. 1, 50, 117

Cetliberg, Mt., nr. Zürich 48, 78, 103,105

Trbachthal, S.W . of Haslithal, above Meiringen, B. Ob. $\because$

Urnerboden, E. side of Clausen P. Ctn. Cri

Urserenthal, Ctn. Iri, upper lieuss V. $\quad \ldots \quad$. $\quad$. 15 ,

Ytznach, at E. end of $\mathrm{L}$. of Zürieh 49,120

Vieallo, nr. Chiasso, S. Ticino 17, 46 Val Anzasea, to W. side of Simplon P., towards Ite. Iosa 11,40,

Val Arpi, nr. Certosa di Pesio 103, 125

Vill Bever, to W. of Upper Engadine, S. of P'onte .. ..

Val Bigontina, nr. Cortina 2ค, 39, (iti, 13:3, 13:5

Val Bregaglia (13ergell), S. side of the Maloja P., Engadine to It. $15,26,45,106 ;, 111,114,117,118$

Val Cavallo, nr. Certosa di Pesio.. 4h

Val Cravina, nr. Certosa di Pesio $2: 3$

Val da Fraële, N.W. of Bormio, It. Tyr.

Val d'Anniviers, to S. of Rhone V., opp. Siere $2,22,28,30,42$, $62,67,80$ (bis). $81,90,91,112$,

$127,128,140$
P.IGE.

Val de Bagnes, above Martigny 80, 130

Val de Boréon, S. of A. Mar. (lir.)

Val de Lantosque, S. of A. Mar. $(\mathrm{Fr}.) \quad \ldots \quad \ldots \quad \ldots, 11$,

Val de Madone, S. of A. Mar. (Fr.)

$16,49,52$

$\mathrm{Val}$ des Fleurs, Nice, Fr. Iiv. 4t, 115

Val d'Hérens, to $S$. of Rhone V., opp. Sion _. .. 5, 57, 10!

Val di Vedro, lower part of Simplon P., S. sille, Pdm.

Tal Ferret or Ferrex, from Orsières, Valais, to Coumayemr, I'dm. $18,22,29,7 \times$,

Val Fex, S. of Sils, L pper Engaline

37, 72

Vallauris, E. of Cannes, Fr. Liv. I.

Val Leventina, $S$. side of St. Gothard P. .. .. 2, 114

Vallon Obseur, Nice, Fr. Riv. 1, 2, $22,26,27,30,34,35,45,46$, $62,63,65,95,98,107,115$

Vallorbe, Jura Vaudois $29,49,106$, 112,137

Val Maggia, Ticino, N. from L. $\begin{array}{llllll}\text { Naggiore } & \ldots & \ldots & \ldots & 121\end{array}$

Val Malenco, N. from Sondrio in Val Tellina, It. Tyr. . . 2, 18, st

Yal Marguareis, S.IV. P'lm., nr. Certosa di Pesio ..6, 125, 139

Val Misox (Mesocco), S.W. Grisons, the $\mathrm{S}$. side of Bernardine P. 2, $81,100,101,106,114,118$

Val Inerta, from Beaulieu to the Corniche, Fr. Iiv. . . . 107

Tal Muranza, S.E. Grisons, N. of $\begin{array}{lllll}\text { the Stelvio } & \ldots & \ldots & \ldots & 134\end{array}$

Val Pari, nr. Cer'tosa di Pesio .. ts

Val Pellice, W. Pdm. leatding to the Col de la Croix and Abriès .. 96

Val Sesia, btwn. L. of Orta and Varallo.. $\quad$. $\quad \ldots \quad \ldots 101$

Val Sestrera, nr. Certosi di Pesio 29, tí

Val Solda, N. of L. of Lugano (It.) ss

Val Tellina (Veltlin), from L. of Como to the Stelvio, It. Tyr.

Val Travers, Jura, above I. of Neuchatel $\quad$. $\quad \ldots \quad$.. 120

Val Thoi, to N. of Lower Engadine above Guarda $39,56,4^{\circ}, \times 7$, 125 (bis)

Val Véni, Piedmont, alove Courmilveul . . ․․, 139,141

Varen, above Rhone $\mathrm{V}$. on $\mathrm{WV}$. of Dala Gorge, mr. Loüche 4, 30, 49, 8. $, 47,9 \mathrm{~s}, 104$

Yarenna, on E. bank of L. of Como 72 Yarzo, P'dm. S. side of Simplon P'. 16 Vence, in S. of A. Mar. (Fr.) .. 5.3 Venanson, below S. Martin Vésubie, A. Mar. (Fr.) ․ . .71, 77, Vernayaz, Rhone V. 15. 16, 23, 2.5, $33,39,40,45,59,77,117$ Versoix, nr. Geneva, to N. $\quad+, 20$ 
(bis), 21, 22, 44, 83, 97, 100,

$107,110,114$

Vevey, Vaud, N. of $\mathbf{L}$. of Genevir

Veyrier, nr. Geneva, to S.E. 1, 2 86,107

$9,17,19,25,26,29,33,39$,

$44,45,46,48$ (bis), 49, 50, 82,

$98,100,105,106,111$ (bis), 117

Veytaux, btwn. Montreux and

Chillon, L. of Geneva 2, 6, 8

(bis), 11, 14, 17 (bis), 18, 22, 24.

25,26 (bis) $27,28,33,36,45$,

$46,60,65,79,89,97,98,105$,

Vex, opp. Sion, Rhone Y 117 (bis)

Via Mala, S. of Thusis, 1... part of

Splugen P.

. 22,132

Vicosoprano, Val Bregaglia, Grisons 129

Vienna, Austria .. $\quad . \quad 31,98$

$\begin{array}{llll}\text { Villach, S. Car. } \quad \ldots & \ldots 11,22,101\end{array}$

Villard sur Clarens, above Montreux 19

Villard, B:A. $\quad$. $\quad \ldots \quad \ldots .47$

Villar's sur Bex (sur Gryon), Vaü, above Rhone V. 14, 19, 21, 73, 78

Villefranche (Villafranca), Fr. Riv. 65,144

Villeneuve, Vaud, at head of L. of Geneva... ..78, 101, 110, 117

Vinadio, S.W. Pdm., N. of the Stura 56

Visp, Rhone $V . \quad 5,14,17,19,30$, $34,40,42,63,72,84,88$ (bis), $89,107,117,118$

Visperterbinen, btwn. Visp and Stalden, of Rhone V. $21, \quad 62$

Vissoye, Val d' Amniviers 28. 62 ,

Vouvry, Rhone V., btwn. Bouveret, and St. Yaurice bet. Bouveret

Walenstadt, S. of Ctn. St. Gall .. 57

Wasen or Wassen (St. Gotthari), high in the lienssthal .. 57

Wasen (Simplon), above bérisal $7 \ddot{4}, 142$
Weesen, at W. end of Walensee 20

PAGE. (bis), 75,120

Weggis, at ft. of the Rigi on L. of Lucerne $\quad . \quad \quad \ldots \quad 8,17,29$

Weggithal, Ctn. Schwyz, W. of Walensee $\quad . \quad \ldots \quad 57,131$

Wreissbad, S. of Appenzell $\quad$. 120

Weissenburg, Simmenthal, B. Ö. $2,5,6$ (bis), 8, 10 (bis), 11, 14, $26,28,29,33,45,48,49,50$, $53,55,57,60,66,70,74,75$, $82,89,98,103,110,117$ (bis), $123,128,131,138,139$

Weissenstein (Grisons), nr. top of Albula P. .. 67,103

Weissenstein (Soleure), Jura 43, 45, 130

Wengen, B. Ob., above Lanterbrumnen $\because \cdots \quad \ldots 2,130$

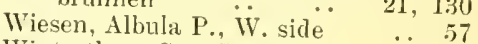

Winterthur, Ctn. Zürich .. $\quad \ldots .95$

Wolfsberg, Lavantthal, S.E. Car. $12,17,18,20$ (bis), 21, 41, 44, $45,49,92,99,101$

Worb, E. of Berne .. . . . . 110

Wyl, N.W. comer of Ctn. St. Gall 114

Yvoire, Sav., nr. Geneva, on L.33, 98

Zermate, at head of Visp V. to S. of Rhone V.1, 5 (bis), 6, 8, 10 , $13,14,21,22,25,32,33$ (bis), $34,36,39,41,49,67,70,74$, $76,88,103,107,117,11 \kappa, 129$, $133,137,141$

Zernetz, Lower Engadine.. 114, 134

Zinal, Val d'Annivier's 2, 5, 13, $28,33,39,41,56,58,74,78$ (bis), 81, 121, 129, 132

Zmutthal, S.W. of Zermatt .. 62

Zofingen., S. of Ctn. Aargau $\quad \ldots \quad 62$

Zürich, N.E. Switz. $5, \overline{7}, 21, \ddot{2} 9$ $35,44,48$ (bis) $49,50,70,75$, $8 . \%, 110,111,116,120$ 
$270^{-1}$ 
